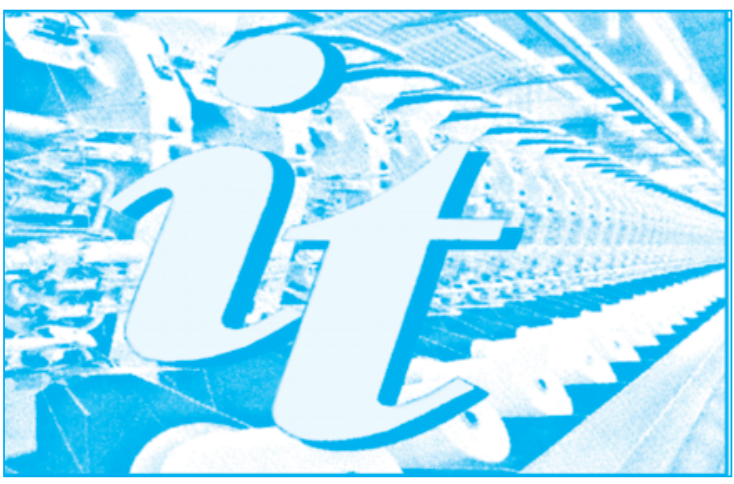

ISI rated journal, included in the ISI Master Journal List of the Institute of Science Information, Philadelphia, USA, starting with vol. 58, no. 1/2007, with impact factor 0.504 and AIS 0.046 in 2018.

The journal is indexed by CrossRef, starting with no. 1/2017 having the title DOI: https://doi.org/10.35530/IT.

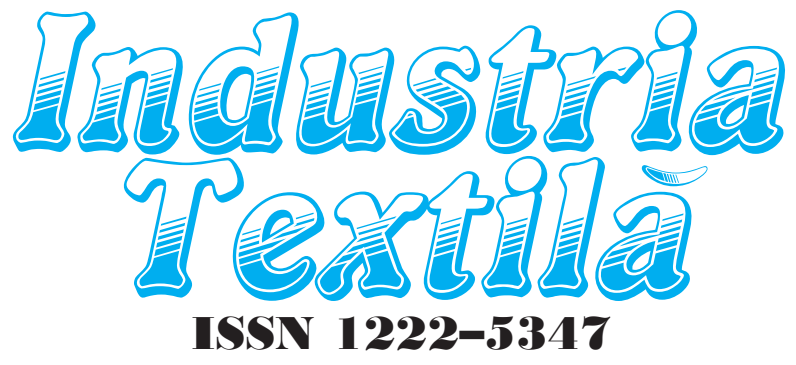

6. 12019

Edited in 6 issues per year, indexed and abstracted in: Science Citation Index Expanded (SciSearch $\left.{ }^{\circledR}\right)$, Materials Science Citation Index ${ }^{\circledR}$, Journal Citation Reports/Science Edition, World Textile Abstracts, Chemical Abstracts, VINITI, Scopus, Toga FIZ technik ProQuest Central, Crossref

Edited with the Romanian Ministry of Education and Research support

\section{INIDUSTRIA TEXTILA \\ EDITORIAL BDARD:}

Dr. Eng. CARMEN GHITULEASA GENERAL MANAGER

National R\&D Institute for Textiles and Leather, Bucharest, Romania

Dr. Eng. SABINA OLARU CS II, EDITOR IN CHIEF

National R\&D Institute for Textiles and Leather Bucharest, Romania

Dr. Eng. EMILIA VISILEANU CS I, HONORIFIC EDITOR

National R\&D Institute for Textiles and Leather, Bucharest, Romania Prof. XIANYI ZENG

Ecole Nationale Superieure des Arts et Industries Textiles (ENSAIT), France

Prof. Dr. Eng. LUIS ALMEIDA University of Minho, Portugal

Prof. Dr. STJEPANOVIČ ZORAN

University of Maribor, Faculty of Mechanica Engineering, Department of Textile Materials and Design, Maribor, Slovenia

Lec. ALEXANDRA DE RAEVE University College Ghent, Fashion, Textile and Wood Technology Department, Belgium

Prof. Dr. Eng. ERHAN ÖNER Marmara University, Turkey

Prof. Dr. S. MUGE YUKSELOGLU Marmara University, Turkey Dr. MAZARI ADNAN ASSISTANT PROFESSOR

Department of Textile Clothing, Faculty of Textile Engineering, Technical University of Liberec Czech Republic Dr. AMINODDIN HAJI

PhD, MSc, BSc, Textile Chemistry and Fiber Science ASSISTANT PROFESSOR

Textile Engineering Department

Yazd University, Yazd, Iran Prof. Dr. Eng. CARMEN LOGHIN

Faculty of Industrial Design and Business Management, Technical University "Gh. Asachi", laşi, Romania

Associate Prof. Dr. Eng. MARIANA URSACHE DEAN

Faculty of Industrial Design and Business Management, Technical University

"Gh. Asachi", laşi, Romania

Prof. Dr. GELU ONOSE

$$
\text { CS I }
$$

"Carol Davila" University of Medicine and Pharmacy, Bucharest, Romania

Prof. Dr. DOINA I. POPESCU

The Bucharest University of Economic Studies, Bucharest, Romania

Prof. Dr. MARGARETA STELEA FLORESCU

The Bucharest University of Economic Studies, Bucharest, Romania
SERAP BILTEKIN AYCA GURARDA

Investigation of the effect of cotton knitted fabric structure of babywear on moisture management properties

$495-501$

MUHAMMAD TUSIEF QAMAR, HUSSAN MALIK MUMTAZ, MUHAMMAD MOHSIN, HAFIZ NAEEM ASGHAR, MUHAMMAD IQBAL, MAHMOOD NASIR

Development of floating treatment wetlands with plant-bacteria partnership

to clean textile bleaching effluent

$502-511$

DUYGU YAVUZKASAP AYAKTA, NAZLI ÇAĞLAR CINPERI, HAKAN ÖZDEMIR

Investigating the effect of self-cleaning treatment on the air permeability,

stain removal and water repellency properties of functionalized double jacquard woven upholstery fabrics

CANDAN AKCA

A new method: the usage of natural zeolite as a killer chemical for hydrogen peroxide during the hydrogen peroxide bleaching

PONNUSAMY VENKATARAMANAN, PAULRAJ PRATHAP,

PALANISAMY SIVAPRAKASH, KANCHANA SIVAPRAKASH

Fire safety in textile industries - A Review

RALUCA MARIA AILENI, SILVIA ALBICI, LAURENTIU DINCA, LILIOARA SURDU

Bivariate analysis of the hydrophobic textiles obtained by plasma treatment

RALUCA MARIA AILENI, LAURA CHIRIAC, ELENA PERDUM,

ELENA CORNELIA MITRAN, LILIOARA SURDU

Aspects concerning the mathematical distribution of metal microparticles on the textile surfaces with electroconductive properties obtained by printing method

I. BHUVANESHWARRI, A. TAMILARASI

Predicting the fabric width of single jersey cotton knitted fabric using appropriate software

EFTALEA CĂRPUS, ANGELA DOROGAN, MIHAI-GABRIEL MATACHE, VALENTIN VLĂDU'T, ADRIANA MUSCALU

Creativity, innovation and future - the key points regarding the "architecture" for the production of agro-textiles

MANOJ KUMAR PARAS, LARS HEDEGÅRD, ANTONELA CURTEZA, RUDRAJEET PAL, YAN CHEN, LICHUAN WANG

The study of 3Rs - Reuse, Repair, and Redesign at Swedish recycling mall

INDRIE LILIANA, MEHMET METE MUTLU, NILAY ORK EFENDIOGLU,

TRIPA SIMONA, PABLO DIAZ GARCIA, MIQUEL SOLER

Computer aided design of knitted and woven fabrics and virtual garment simulation

$519-522$

$523-526$

$527-532$

JIANG YAN, HUA QIU

Numerical simulation of the effect of flow field in swirl nozzle spinning

on yarn performance

MUHAMMAD ZIA-UR-REHMAN, SAJJAD AHMAD BAIG, MUHAMMAD ABRAR, MUHAMMAD HASHIM, FIZA AMJAD, IRFAN AHMAD BAIG, MUHAMMAD USMAN

The impact of intellectual capital, organizational capabilities and innovation on firm performance of textile sector: a moderating effect of GSP Plus

MARIAN NASTASE NICOLAE BIBU, ANCA-IOANA MUNTEANU,

ILEANA MIRCIOI (VALIMAREANU), MARGARETA STELA FLORESCU

The specific elements of strategic human resources management

for competitive business development

$579-586$

MARGARETA STELA FLORESCU, ADRIANA ANA MARIA DAVIDESCU,

ANCA-IOANA MOSORA, CRISTINA ALPOPI, MARIAN NASTASE

Assessment of the research field in the European universities and analysis

of the research projects impact on academic performance

Web of Science Journal Category: Materials Science, Textiles

Aknowledged in Romania, in the engineering sciences domain, by the National Council of the Scientific Research from the Higher Education (CNCSIS), in group $A$ 


\section{O

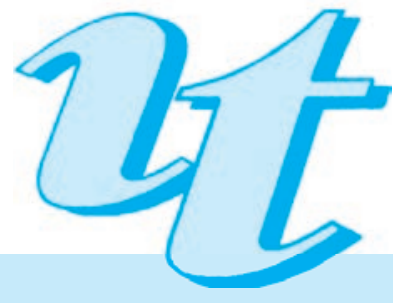

Scientific reviewers for the papers published in this number:

Dr. NAVEED RIZVI, Research \& Development Manager, RONCO, Canada

Dr. WENWEN ZHANG, NC State University, College of Textiles, North Carolina, United States

Dr. LIN LIN, Interdisciplinary Nanoscience Center (iNANO), Aarhus University, Denmark

Assoc. Prof. Dr. GHULAME RUBBANIY, College of Business, Zayed University Abu Dhabi, United Arab Emirates

Dr. DANIL PALET, Eco-Engineering Association of Textile Finishing of Terrassa - AEETT, Barcelona, Spain

Asst. Prof. Dr. XIAOLING SONG, Najing University of Science and Technology, Department of Management Sciences and Engineering, China

Prof. KJARTAN SIGURDSSON, Reykjavik University, Iceland

Prof. BEHÇET BECERIR, Uludağ University, Faculty of Engineering Textile, Engineering Department, Turkey

Assoc. Prof. MINE AKGUN, Uludağ University, Faculty of Engineering Textile, Engineering Department, Turkey

Prof. Dr. ELSAYED ELNASHAR, Kafrelsheikh University, Egypt

Prof. Dr. KADIR BILIŞIK, Fiber Science and Engineering, Erciyes University, Turkey

Assoc. Prof. Dr. MUHAMMED AKAYDIN, Pamukkale University, Turkey

Prof. Dr. IBRAHIM BAHTIYARI, Erciyes University, Turkey

Prof. Dr. AYŞEGÜL KÖRLÜ, Ege University, Department of Textile Engineering, Engineering Faculty, Turkey

Dr. SOKE SUNDAY AYOOLA, University of Lagos, Department of Mechanical Engineering, Nigeria

Asst. Prof. Dr. HAFSA JAMSHAID, National Textile University, Faisalabad, Pakistan

Asst. Prof. Dr. AMINODDIN HAJI, Yazd University, Iran

Assoc. Prof. Dr. PRABHAKAR RONTALA, University of Kwa Zulu-Natal, Information Systems \& Technology Department, Post Graduate Centre, Pietermaritzburg, South Africa

Asst. Prof. Dr. GIZEM KARAKAN GÜNAYDIN, Pamukkale University, Turkey

Asst. Prof. Dr. GEETIKA VARSHNEYA, Development Management Insitute, India

Assoc. Prof. Dr. MUSA KILIK, Dokuz Eylül University, Faculty of Engineering, Department of Textile Engineering, İzmir, Turkey

Prof. Dr. AURELIA LITVIN, State Agrarian University of Moldova, Department of Business and Aministration, Moldova Republic

\section{EDITORIAL STAFF}

General Manager: Dr. Eng. Carmen Ghițuleasa

Editor-in-chief: Dr. Eng. Sabina Olaru

Onorific editor: Dr. Eng. Emilia Visileanu

Graphic designer: Florin Prisecaru

Translator: Cătălina Costea

Site administrator: Constantin Dragomir

e-mail: industriatextila@ incdtp.ro

INDUSTRIA TEXTILA journal, edited by INCDTP BUCHAREST, implements and respects Regulation 2016/679/EU on the protection of individuals with regard to the processing of personal data and on the free movement of such data ("RGPD"). For information, please visit the Personal Data Processing Protection Policy link: e-mail DPO rpd@certex.ro

Journal edited in colaboration with Editura AGIR, 118 Calea Victoriei, sector 1, Bucharest, tel./fax: 021-316.89.92; 021-316.89.93; e-mail: editura@agir.ro, www.edituraagir.ro 


\title{
Investigation of the effect of cotton knitted fabric structure of babywear on moisture management properties
}

\author{
DOI: $10.35530 / 1 T .070 .06 .1658$
}

\section{ABSTRACT - REZUMAT}

\section{Investigation of the effect of cotton knitted fabric structure of babywear on moisture management properties}

In recent years, baby clothing has become an important role in the garment sector. The increasing importance of baby clothing, along with the new designs, different fabric structures, accessories and clothing comfort is required to develop. Due to the increasing importance given to baby health in the world, babywears have to be manufactured from materials that are not harmful to health in accordance with the standards.

The purpose of this study is to investigate the effect of cotton knitted fabrics structure of babywear on moisture management properties. For this reason, moisture management properties (wetting time, absorption rate, spreading speed, accumulative one-way transport capability (OWTC) and overall moisture management capability (OMMC)) of cotton knitted fabrics of different structures which are widely used in babywear have been examined. Moisture management tester was used for liquid transport of the knitted fabric samples.

As a result of the study, it is observed that single jersey fabric had higher OMMC values than these of interlock and $1 \times 1$ rib knitted fabrics. Regarding the effect of yarn thickness, liquid transport increased with decreasing yarn thickness in general. Regarding the effect of fabric weight and fabric thickness, liquid transport decreased with increasing weight and thickness in general. Negative correlations were observed between fabric weight, fabric thickness and overall moisture management capability.

Keywords: babywear, moisture management, cotton, knitted

\section{Influența structurii tricoturilor de bumbac din îmbrăcămintea pentru bebeluși asupra proprietăților de control a umidității}

În ultimii ani, îmbrăcămintea pentru bebeluși a înregistrat un rol din ce în ce mai important în sectorul articolelor de îmbrăcăminte. Această importanță, împreună cu noi modele, diferite structuri ale materialelor textile, accesoriile și confortul vestimentar necesită noi abordări. Datorită importanței acordate sănătății bebelușului, îmbrăcămintea trebuie să fie realizată din materiale care nu sunt dăunătoare sănătătiii, în conformitate cu standardele în vigoare.

Scopul acestui studiu este de a investiga influența structurii tricoturilor de bumbac din îmbrăcămintea pentru bebeluși asupra proprietăților de control a umidității. Din acest motiv, au fost studiate proprietăţile aferente controlului umidităţii (timpul de umectare, rata de absorbție, viteza de umezire, capacitatea acumulată de transport unidirecțional (OWTC) și capacitatea generală de control al umidității (OMMC)) din tricoturile de bumbac cu diferite structuri, care sunt utilizate pe scară largă în îmbrăcămintea pentru bebeluși. Testerul de control al umidității a fost utilizat pentru transportul lichidelor din probele de tricot.

Ca rezultat al studiului, se observă că tricoturile glat prezintă valori ale OMMC mai mari decât tricoturile interlock și tricoturile patent 1x1. În ceea ce privește influenţa fineții firelor, transportul lichidului a crescut odată cu creştere fineţii firelor. Din punctul de vedere al influenţei masei şi grosimii tricoturilor, transportul lichidului a scăzut odată cu creșterea masei şi grosimii. Au fost observate corelații negative între masa tricotului, grosimea tricotului și capacitatea totală de control al umidității.

Cuvinte-cheie: îmbrăcăminte pentru bebeluși, controlul umidității, bumbac, tricot

\section{INTRODUCTION}

Babywear is a clothing product category for babies and infants up to 2 years old. In recent years, baby clothing has become an important place in the garment sector. The increasing importance of baby clothing, along with the new designs, different fabric structures, accessories and clothing comfort is required to develop. Due to the increasing importance given to baby health in the world, babywears have to be manufactured from materials that are not harmful to health in accordance with standards.

Today more than $50 \%$ of babywear is made of knitted fabric and most of them are used cotton. Choosing the right fabric is very important when producing babywear. The choice of the right fabric in the babywear increases the quality of the garment, the consumer's desire to buy the garment and the comfort of the baby in the garment.

Infant's clothing is sized according to their age: 3,6 , $12,18,24$ months. During this age, the head does not correctly stand on their neck. So, garments should be selected with a full opening. According to the seasons, the material should be selected, thick or thin. Also, soft materials with the lightweight should be selected [1].

Fabrics of babywear must be durable to wear and tear. Babies prefer soft, absorbent fabrics that do not 
scratch their body. Cotton or polyester cotton blends provide comfort, durability, and easy care for fabrics of babywear.

The selection of suitable cloth for the babies allows them to move comfortably. The cloth should not irritate the delicate skin of the baby. When selecting babywear, there are a few things needed to be aware of in order to keep baby safe and comfortable. So, the patterns of the babywear should be simple and comfortable [1]. For babies, comfort and safety are very important. The fabric should not be sticky, slippery or thick, but also breathable. The fabric also has to withstand of washing. Fabrics of babywear should transfer the sweat outside quickly to provide tactile and sensorial comfort for babies [2].

The ideal babywear should be soft, comfortable, easy to put and take off, ligthweight, non-irritating and allow quick transmission of sweat from skin to environment.

Moisture management transmission is one of the most important performance properties, which determine the comfort level of the fabric, in the clothing industry. When any liquid is dropped on the surface of a fabric, it moves into multiple directions and its movement depends upon the structure of the fabric. The properties of the fabric regarding the liquid and moisture transport into multiple dimensions are called the moisture management transmission properties [3-4].

The primary cooling mechanism of the body is evaporation of perspiration. The behavior of the moisture absorbed at the fabric inner surface and evaporated at the outer surface significantly influences the babies comfort. Therefore, it is necessary to determine the fabric structural properties before the design of babywear. Babywear needs the ability to transfer sweat from skin's surface to the outer side of the garment to evaporate and then to maintain the dry sensation during sleeping or playing with a heavy sweating rate [5-6].

To improve the comfort of the babywears, it is important to know the liquid moisture management properties of the fabrics [7-8]. In fabric structures, for high moisture management properties generally, cotton fibers are used in order to maximize transport moisture properties.
The purpose of this study is to investigate the effect of the babywear cotton knitted fabrics structure on moisture management properties. For this reason, moisture management properties (wetting time, absorption rate, spreading speed, accumulative oneway transport capability (OWTC) and overall moisture management capability (OMMC)) of cotton knitted fabrics of different structures which are widely used in baby clothing have been examined.

\section{MATERIALS AND METHODS}

\section{Materials}

In this study, moisture management properties of six types of cotton knitted fabrics at two groups with different structural properties which are widely used for baby wears were examined. Fabric samples at the first group have same weave type (interlock) but different yarn counts. Fabric samples at the second group have different weave types but nearly same yarn count. At this study, effect of yarn counts, weave types, fabric thickness and fabric weight of $100 \%$ cotton knitted fabrics was investigated and trying to find best fabric structure for moisture management properties for babywears. Basic properties of fabric samples for this study are shown in table 1.

\section{Methods}

In this study, moisture management properties tests were made to the fabric samples. The ASTM D 377609a standard was used to measure the mass per unit area [9]. The ASTM D1777-96 (2007) standard was used to measure the thickness values of fabric samples [10].

Moisture management properties were measured by SDL Atlas M 290 Moisture Management Tester (MMT) instrument (figure 1) according to AATCC 195 standard [11]. Fabric sample is placed horizontally in the instrument between the upper and lower sensors (figure 2). Wetting time of the top and bottom surface, absorption rate of top and bottom surface, spreading speed of the top and bottom surface, accumulative one-way transport capability and overall moisture management capability of the fabric samples were examined to determine the proper babywear knitted fabric structure for moisture transfer.

\begin{tabular}{|c|c|c|c|c|c|c|c|c|}
\hline \multicolumn{9}{|c|}{ STRUCTURAL PARAMETERS OF FABRIC USED } \\
\hline $\begin{array}{l}\text { Fabric } \\
\text { groups }\end{array}$ & $\begin{array}{l}\text { Fabric } \\
\text { code }\end{array}$ & $\begin{array}{c}\text { Weave } \\
\text { type }\end{array}$ & $\begin{array}{c}\text { Yarn count } \\
\text { (Ne) }\end{array}$ & Material & $\begin{array}{l}\text { Thickness } \\
(\mathrm{mm})\end{array}$ & $\begin{array}{c}\text { Weight } \\
\left(\mathrm{g} / \mathrm{m}^{2}\right)\end{array}$ & $\begin{array}{l}\text { Wales } \\
\text { per cm }\end{array}$ & $\begin{array}{c}\text { Courses } \\
\text { per } \mathbf{c m}\end{array}$ \\
\hline \multirow{4}{*}{$1^{\text {st }}$ group } & A1 & Interlock & $24 / 1$ & $100 \%$ Cotton & 0.82 & 265 & 12 & 14 \\
\hline & $\mathrm{A} 2$ & Interlock & $36 / 1$ & $100 \%$ Cotton & 0.75 & 210 & 15 & 14 \\
\hline & A3 & Interlock & $50 / 1$ & $100 \%$ Cotton & 0.69 & 160 & 18 & 14 \\
\hline & A4 & Interlock & $60 / 1$ & $100 \%$ Cotton & 0.59 & 155 & 18 & 17 \\
\hline \multirow{3}{*}{$2^{\text {nd }}$ group } & A1 & Interlock & $24 / 1$ & $100 \%$ Cotton & 0.82 & 265 & 12 & 14 \\
\hline & A5 & $1 \times 1$ rib & $30 / 1$ & $100 \%$ Cotton & 0.72 & 205 & 12 & 19 \\
\hline & A6 & Single Jersey & $30 / 1$ & $100 \%$ Cotton & 0.40 & 155 & 16 & 20 \\
\hline
\end{tabular}




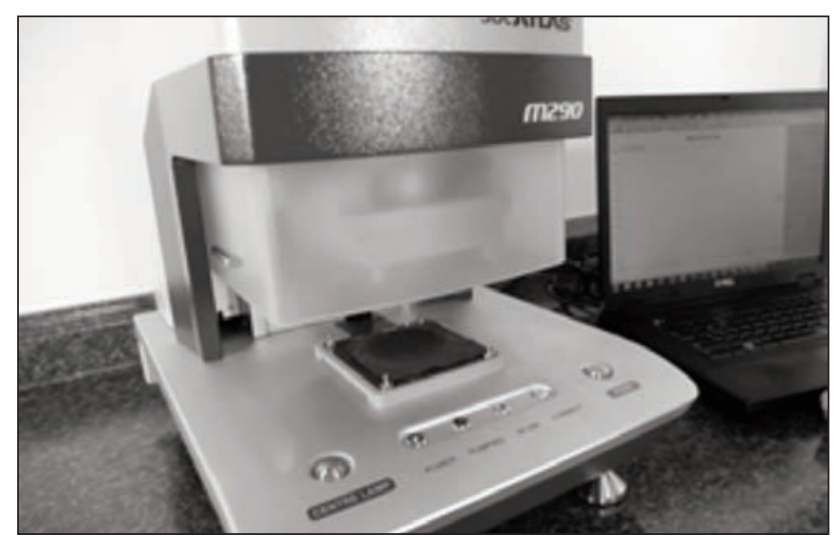

Fig. 1. Moisture management tester (MMT) [7]

MMT test results were evaluated using the grading scale, which is a 5-point scale, given according to AATCC Test Method 195 (2012). For each fabric, five repetitions were made, and the arithmetic mean was calculated from the individual measurement results. At grading scales of AATCC Test Method 195, the excellent value for wetting time is $(<3)=$ very fast, for absorption rate is $(>100)=$ very fast, for spreading speed is $(>4)=$ very fast, for accumulative one-way transport capability is $(>400)=$ excellent and for overall moisture management capability (OMMC) is $(>0.8)$ $=$ excellent, so that a fabric which has these values is excellent for liquid transmission.

Prior to the tests, all fabric samples were conditioned for 24 hours in standard atmospheric conditions (at a temperature of $20 \pm 2^{\circ} \mathrm{C}$ and relative humidities of 65 $\pm 2 \%$ ).

The results were evaluated statistically by using SPSS 14.0 program. Completely randomized singlefactor (one way) multivariate analysis of variance (ANOVA) as a fixed model was applied to data. Student-Newman-Keuls (SNK) tests were used to compares the means. The treatment levels were marked in accordance with the mean values, and levels were marked with the different letter $(a, b, c$ and d) to show that they were significantly different.

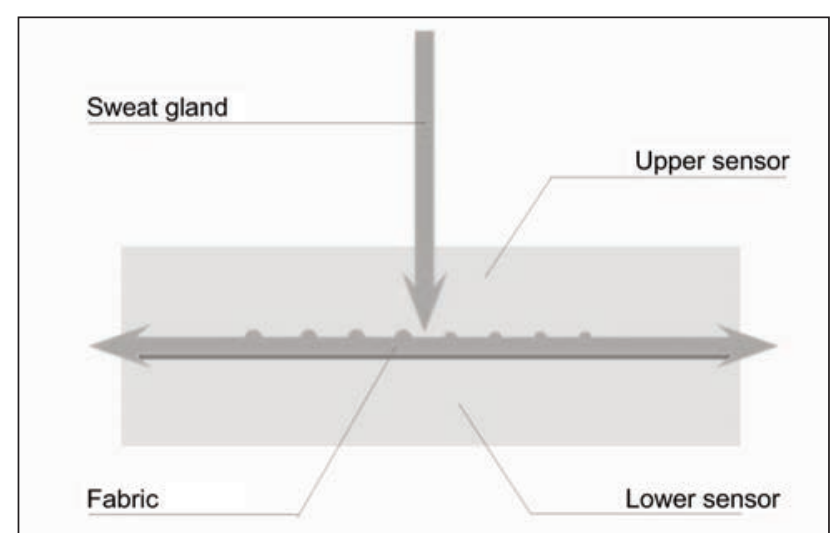

Fig. 2. Sketch of moisture management tester sensors [7]

The correlation coefficients were calculated to determine the relationships between fabric structural properties (weight, thickness and yarn count) and fabric moisture management properties (wetting time, absorption rate, spreading speed, accumulative oneway transport capability and overall moisture management capability).

\section{RESULTS AND DISCUSSION}

Wetting time (top and bottom), absorption rate (top and bottom), spreading speed (top and bottom), accumulative one-way transport capability (OWTC) and overall moisture management capability (OMMC) test results of the fabric samples are presented in figures 3-7. Analysis of variance and Student-NewmanKeuls test results are given in tables 2 and 3 .

The correlation coefficient values between the fabric structural properties (weight, thickness and yarn count) and moisture management properties of fabrics are presented in table 4. Positive correlations were observed between weight, thickness and wetting time. In other words, the wetting time values increased when the fabric weight and thickness increased. The negative correlations were observed between weight, thickness and absorption rate, spreading speed, OWTC and OMMC values, as shown in

Table 2

STATISTICAL ANALYSIS (ANALYSIS OF VARIANCE AND SNK TEST) RESULTS FOR MOISTURE MANAGEMENT PROPERTIES (WETTING TIME AND ABSORPTION RATE)

\begin{tabular}{|c|c|c|c|c|c|c|c|c|c|}
\hline \multicolumn{2}{|c|}{ Parameters } & \multicolumn{2}{|c|}{$\begin{array}{l}\text { Wetting Time Top } \\
\text { (sec) }\end{array}$} & \multicolumn{2}{|c|}{$\begin{array}{l}\text { Wetting Time } \\
\text { Bottom (sec) }\end{array}$} & \multicolumn{2}{|c|}{$\begin{array}{c}\text { Absorption Rate Top } \\
(\% / \mathrm{sec})\end{array}$} & \multicolumn{2}{|c|}{$\begin{array}{c}\text { Absorption Rate } \\
\text { Bottom (\%/sec) }\end{array}$} \\
\hline & & P/Sig. & SNK & P/Sig. & SNK & P/Sig. & SNK & P/Sig. & SNK \\
\hline \multirow{4}{*}{$\begin{array}{c}\text { Yarn } \\
\text { Count } \\
(\mathrm{Ne})\end{array}$} & A1 (24/1) & \multirow{4}{*}{$0.000^{*}$} & $4.46 \mathrm{~d}$ & \multirow{4}{*}{$0.000^{*}$} & $4.37 \mathrm{~d}$ & \multirow{4}{*}{$0.000^{*}$} & $35.74 \mathrm{a}$ & \multirow{4}{*}{0.190} & $50.35 \mathrm{a}$ \\
\hline & A2 $(36 / 1)$ & & $4.11 \mathrm{c}$ & & $4.30 \mathrm{~d}$ & & $49.17 \mathrm{c}$ & & $56.95 \mathrm{a}$ \\
\hline & A3 (50/1) & & $3.44 \mathrm{a}$ & & $3.38 \mathrm{a}$ & & $45.73 b$ & & $52.20 \mathrm{a}$ \\
\hline & A4 (60/1) & & $3.67 \mathrm{~b}$ & & $3.75 \mathrm{~b}$ & & $45.89 \mathrm{~b}$ & & $55.04 \mathrm{a}$ \\
\hline \multirow{3}{*}{$\begin{array}{l}\text { Fabric } \\
\text { Type }\end{array}$} & A1 (interlock) & \multirow{3}{*}{$0.000^{*}$} & $4.46 \mathrm{c}$ & \multirow{3}{*}{$0.000^{*}$} & $4.37 \mathrm{c}$ & \multirow{3}{*}{$0.000^{*}$} & $35.74 \mathrm{a}$ & \multirow{3}{*}{$0.000^{*}$} & $50.35 a$ \\
\hline & A5 (rib) & & $3.59 \mathrm{~b}$ & & $3.57 \mathrm{~b}$ & & $44.86 \mathrm{~b}$ & & $56.07 \mathrm{~b}$ \\
\hline & A6 (jersey) & & $3.06 \mathrm{a}$ & & $3.15 \mathrm{a}$ & & $50.76 a$ & & $75.25 \mathrm{c}$ \\
\hline
\end{tabular}

${ }^{*}$ statistically significant $(P<0.05)$.

a, b, c and d represent statistically difference ranges according to SNK test. 
STATISTICAL ANALYSIS (ANALYSIS OF VARIANCE AND SNK TEST) RESULTS FOR MOISTURE MANAGEMENT PROPERTIES (SPREADING SPEED, OWTC AND OMMC)

\begin{tabular}{|c|c|c|c|c|c|c|c|c|c|}
\hline \multicolumn{2}{|c|}{ Parameters } & \multicolumn{2}{|c|}{$\begin{array}{l}\text { Spreading Speed } \\
\text { (Top) }(\mathrm{mm} / \mathrm{sec})\end{array}$} & \multicolumn{2}{|c|}{$\begin{array}{l}\text { Spreading Speed } \\
\text { (Bottom) }(\mathrm{mm} / \mathrm{sec})\end{array}$} & \multicolumn{2}{|c|}{$\begin{array}{l}\text { OWTC } \\
(\%)\end{array}$} & \multicolumn{2}{|c|}{ OMMC } \\
\hline & & P/Sig. & SNK & P/Sig. & SNK & P/Sig. & SNK & P/Sig. & SNK \\
\hline \multirow{4}{*}{$\begin{array}{c}\text { Yarn } \\
\text { Count } \\
(\mathrm{Ne})\end{array}$} & A1 (24/1) & \multirow{4}{*}{$0.000^{*}$} & $2.43 \mathrm{a}$ & \multirow{4}{*}{$0.000^{*}$} & $2.60 \mathrm{a}$ & \multirow{4}{*}{$0.000^{*}$} & $222.47 \mathrm{~b}$ & \multirow{4}{*}{0.190} & $0.548 \mathrm{a}$ \\
\hline & A2 (36/1) & & $2.88 \mathrm{~b}$ & & $2.86 \mathrm{~b}$ & & $157.68 \mathrm{a}$ & & $0.516 \mathrm{a}$ \\
\hline & A3 $(50 / 1)$ & & $3.66 \mathrm{c}$ & & $3.95 \mathrm{~d}$ & & $317.35 \mathrm{c}$ & & $0.769 \mathrm{~b}$ \\
\hline & A4 $(60 / 1)$ & & $3.52 \mathrm{c}$ & & $3.65 \mathrm{c}$ & & $312.47 \mathrm{~d}$ & & $0.749 \mathrm{~b}$ \\
\hline \multirow{3}{*}{$\begin{array}{c}\text { Fabric } \\
\text { Type }\end{array}$} & A1 (interlock) & \multirow{3}{*}{$0.000^{*}$} & $2.43 a$ & \multirow{3}{*}{$0.000^{*}$} & $2.60 \mathrm{a}$ & \multirow{3}{*}{$0.000^{*}$} & $222.47 \mathrm{a}$ & \multirow{3}{*}{$0.000^{*}$} & $0.548 a$ \\
\hline & A5 (rib) & & $3.32 \mathrm{~b}$ & & $3.48 \mathrm{~b}$ & & $240.45 a$ & & $0.658 \mathrm{~b}$ \\
\hline & A6 (jersey) & & $4.22 \mathrm{c}$ & & $4.53 \mathrm{c}$ & & $309.35 \mathrm{~b}$ & & $0.830 \mathrm{c}$ \\
\hline
\end{tabular}

* statistically significant $(P<0.05)$.

$a, b, c$ and d represent statistically difference ranges according to SNK test.

CORRELATION COEFFICIENT BETWEEN STRUCTURAL AND MOISTURE MANAGEMENT PROPERTIES OF FABRICS

\begin{tabular}{|c|c|c|c|c|c|c|c|c|}
\hline \multirow{2}{*}{ Parameters } & \multicolumn{2}{|c|}{ Wetting Time } & \multicolumn{2}{|c|}{ Absorption Rate } & \multicolumn{2}{c|}{ Spreading Speed } & \multirow{2}{*}{ OWTC } & \multirow{2}{*}{ OMMC } \\
\cline { 2 - 8 } & Top & Bottom & Top & Bottom & Top & Bottom & & \\
\hline Weight & 0.870 & 0.804 & -0.760 & -0.481 & -0.910 & -0.841 & -0.740 & -0.860 \\
\hline Thickness & 0.845 & 0.770 & -0.681 & -0.881 & -0.904 & -0.866 & -0.650 & -0.832 \\
\hline Yarn Count & -0.270 & -0.234 & 0.287 & -0.237 & 0.337 & 0.286 & 0.524 & 0.428 \\
\hline
\end{tabular}

table 4. In other words, the absorption rate, spreading speed, OWTC and OMMC values increased when the the fabric weight and thickness decreased.

\section{Wetting Time (WT) test results}

WT top and bottom range values were compared using the grading scale, which is a 5-point scale, according to AATCC Test Method 195. The grades of the indexes are: $1(\geq 120)=$ non-wetting, $2(20-119)$ = slow, $3(5-19)=$ medium, $4(3-5)=$ fast, $5(<3)=$ very fast.

The wetting time values of the fabric samples are shown in figure 3 . In figure 3 , it was observed that all fabric samples had "fast" WT values. At the first group, fabric sample (A1) with highest thickness and weight had the highest wetting time. At the second group, single jersey fabric sample (A6) had the lowest WT values because it has lowest fabric thickness. The face and back side of fabric samples were named "the top surface" (inner) and "the bottom surface" (outer). The top surface of the fabric is designed to be in touch with the human skin. The top and bottom surfaces of the fabric samples gave almost similar results to each other for wetting time results. The fabric samples aren't thick. So that the wetting time values at the top and bottom surfaces were similar. Cotton fiber has a hydrophilic property. Cotton fabric has a high moisture absorption property; the test liquid penetrates into the cotton fibers.
According to the statistical analysis in table 2, the yarn count $(\mathrm{Ne})$ and fabric type have a significant effect on top and bottom wetting time values of the fabric samples.

Positive correlations were observed between fabric weight, fabric thickness and wetting time, as shown in table 4.

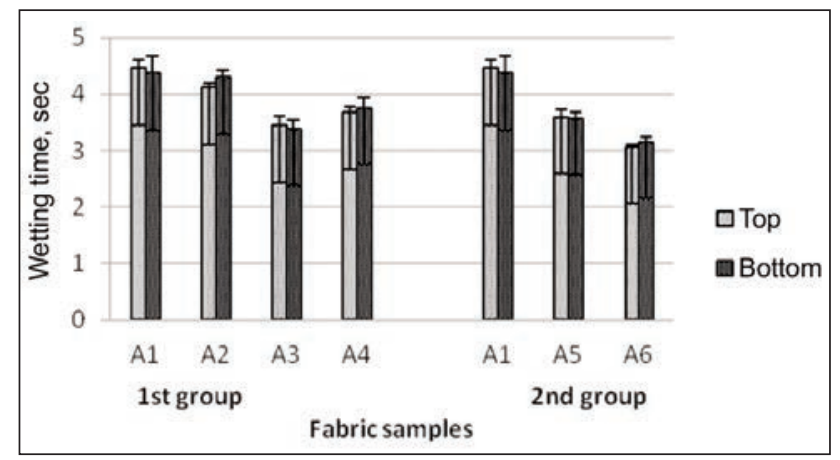

Fig. 3. Wetting time of top and bottom surface of fabric sample

\section{Absorption Rate (AR) test results}

Absorbency is used to describe the ability of a fabric in moisture. AR top and bottom range values were compared using the grading scale, which is a 5-point scale, according to AATCC Test Method 195.

The grades of the indexes are: $1(0-9)=$ very slow, $2(10-29)=$ slow, $3(30-49)=$ medium, $4(50-100)=$ fast, $5(>100)$ = very fast. 
Absorption rates on the top and bottom surfaces $(\% / \mathrm{sec})$ are the average moisture absorption ability of the specimen, in the pump time [12].

The absorption rate values of the fabric samples are shown in figure 4. At the first group, it was observed that (A2), (A3) and (A4) fabric samples AR values higher than (A1). At the second group, it was observed that single jersey fabric sample (A6), AR values higher than $1 \times 1$ rib (A5) and interlock (A1) fabric samples. At these fabric samples when the fabric thickness and fabric weight decrease, AR values increase. The top and bottom surfaces of the fabric samples gave different results to each other. Absorption rate value of bottom surface was higher than top surface. The total water content of the top and bottom surfaces seems to be lower for cotton fabric. The wetted areas on both surfaces are not large, since the water molecules are absorbed by the fibers.

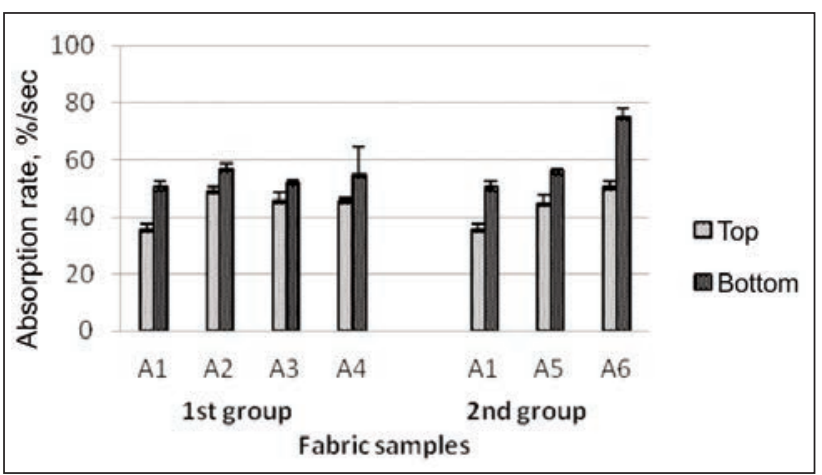

Fig. 4. Absorption of top and bottom surface of fabric samples

According to the statistical analysis in table 2, the yarn count ( $\mathrm{Ne}$ ) and fabric type have a significant effect on absorption rate values of the top surface of the fabric samples but the yarn count $(\mathrm{Ne})$ doesn't have a significant effect on absorption rate values of the bottom surface of the fabric samples.

Negative correlations were observed between fabric weight, fabric thickness and absorption rate, as shown in table 4.

\section{Spreading Speed (SS) test results}

SS top and bottom range values were compared using the grading scale, which is a 5-point scale, according to AATCC Test Method 195. The grades of the indexes are: $1(0.0-0.9)=$ very slow, $2(1.0-1.9)$ = slow, $3(2-2.9)=$ medium, $4(3-4)=$ fast, $5(>4)=$ very fast.

The spreading speed values of the fabric samples are shown in figure 5 . At the first group, it was observed that (A1) and (A2) fabric samples had "medium" and (A3), (A4) fabric samples had "fast" SS values. At the second group (A5) fabric sample had "fast" and (A6) fabric sample had "very fast" SS values. At these fabric samples when the fabric thickness and fabric weight decrease, SS values increase. The top and the bottom surfaces of the fabric samples gave different results to each other. Spreading speed value of bottom surface was higher than top surface. This is because the absorption rate value of bottom surface was higher than top surface.

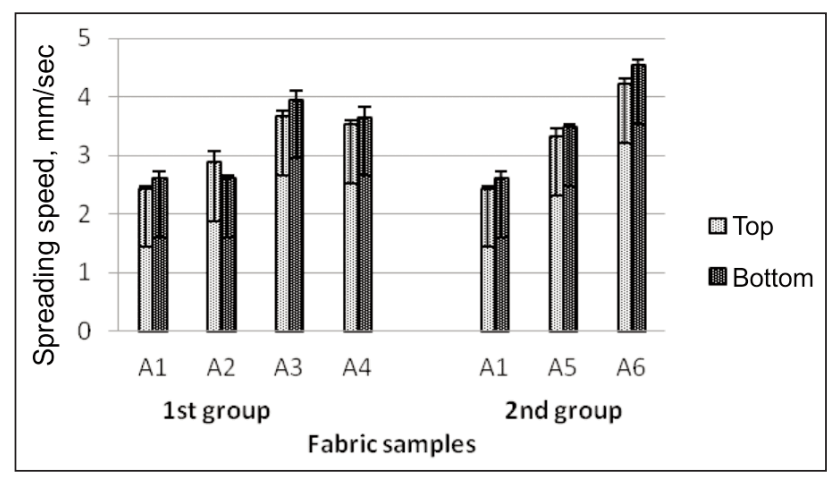

Fig. 5. Spreading speed of top and bottom surface of fabric samples

According to the statistical analysis in table 3 , the yarn count $(\mathrm{Ne})$ and fabric type have a significant effect on spreading speed values of the top and the bottom surfaces of the fabric samples.

Negative correlations were observed between fabric weight, fabric thickness and spreading speed, as shown in table 4.

\section{Accumulative One-Way Transport Capability (OWTC) test results}

OWTC means, the difference of the cumulative moisture content between the two surfaces of the fabric. OWTC value gives the difference between the area of the liquid moisture content curves of the top and the bottom surfaces of a specimen with respect to time.

OWTC range values were compared using the grading scale, which is a 5-point scale, according to AATCC Test Method 195. The grades of the indexes are: $1(<-50)=$ very poor, $2(-50-99)=$ slow, 3 $(100-199)=$ good, $4(200-400)=$ very good, $5(>400)$ = excellent.

The OWTC values of the fabric samples are shown in figure 6 . At the first and the second groups, it was observed that all fabric samples except A2 had "very good" OWTC values. A2 had "good" OWTC value. The reason for this explains with the denser structure of fabric sample A2 than A1. In these fabric samples,

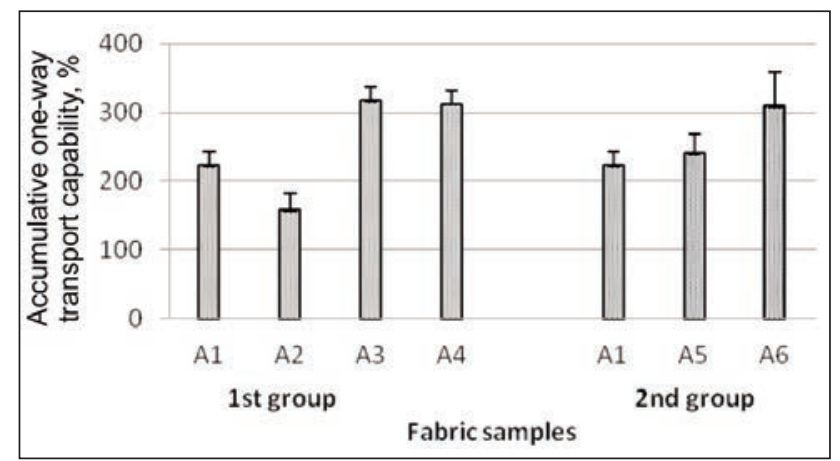

Fig. 6. Accumulative one-way transport capability of top and bottom surface of fabric samples 
when the fabric thickness and fabric weight decrease, OWTC values increase.

According to the statistical analysis in table 3 , the yarn count $(\mathrm{Ne})$ and fabric type have a significant effect on OWTC values of the fabric samples.

Negative correlations were observed between fabric weight, fabric thickness and accumulative one-way transport capability, as shown in table 4.

\section{Overall Moisture Management Capability (OMMC) test results}

OMMC is an index that determines the total transfer capacity of the liquid moisture in a fabric. Overall moisture management capability indicates the overall ability of the fabric to manage the transport of liquid moisture, which includes three aspects of performance; moisture absorption rate of the bottom side, one-way liquid transport ability and maximum spreading speed of the bottom side [13-16]. The overall moisture management capacitiy (OMMC) was calculated using equation 1.

$$
\text { OMMC }=C_{1} A_{B}+C_{2} \text { OWTC }+C_{3} S_{B}
$$

Where $C_{1}, C_{2}$ and $C_{3}$ are the weights of the indexes of the absorption rate of the bottom surface $\left(A R_{B}\right)$, the one-way transport capability (OWTC) and the spreading speed of the bottom surface $\left(\mathrm{SS}_{\mathrm{B}}\right)$. Here $\mathrm{C}_{1}=0.25, \mathrm{C}_{2}=0.5$ and $\mathrm{C}_{3}=0.25$, and they are adjustable in practice according to end-of-use purposes.

The high overall moisture management capacity value means that the moisture transfer is high [12]. OMMC range values were compared using the grading scale, which is a 5-point scale, according to AATCC Test Method 195. The grades of the indexes are: $1(0.0-0.19)=$ very poor, $2(0.2-0.39)=$ poor, $3(0.4-0.59)=$ good, $4(0.60-0.80)=$ very good, 5 $(>0.80)=$ excellent.

The OMMC values of the fabric samples are shown in figure 7. At the first group, it was observed that (A1), (A2) had "good" and (A3), (A4) had "very good". At the second group, (A1), (A5) had "good" and (A6) had "excellent" OMMC values. At these fabric samples when the fabric thickness and fabric weight decrease, OMMC values increase.

According to the statistical analysis in table 3 , the fabric type has a significant effect on the OMMC values of the fabric samples.

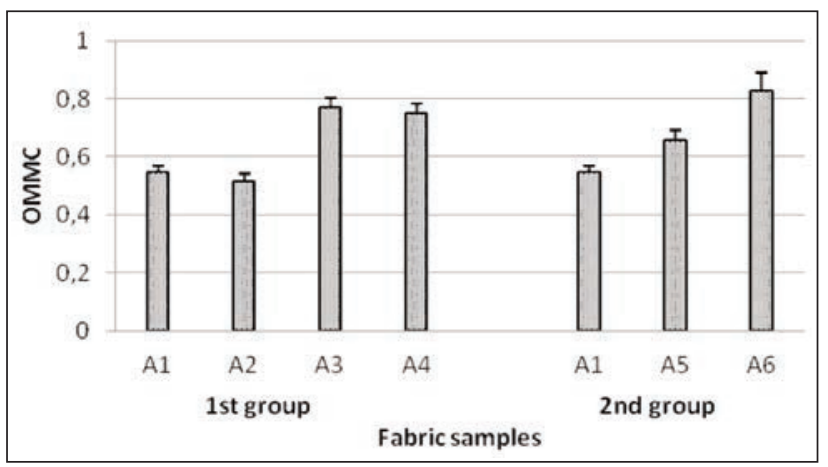

Fig. 7. Overall moisture management capability of top and bottom surface of fabric samples
Negative correlations were observed between fabric weight, fabric thickness and overall moisture management capability, as shown in table 4.

\section{CONCLUSION}

In recent years, baby clothing has become an important role in the garment sector. The increasing importance of baby clothing, along with the new designs, different fabric structures, accessories and clothing comfort is required to develop.

Today more than $50 \%$ of babywear is made of knitted fabric and most of them are used cotton. Choosing the right fabric is very important when producing babywear. The choice of the right fabric in the babywear increases the quality of the garment, the consumer's desire to buy the garment and the comfort of the baby in the garment.

The primary cooling mechanism of the body is evaporation of perspiration. The behavior of the moisture absorbed at the fabric inner surface and evaporated at the outer surface significantly influences the babies comfort. Therefore, it is necessary to determine the fabric structural properties of moisture transfer before design of babywear. Babywear needs the ability to transfer sweat from skin's surface to the outer side of the garment to evaporate and then to maintain the dry sensation during sleeping or playing with a heavy sweating rate.

Fabrics of babywear must be durable to wear and tear. Babies prefer soft, absorbent fabrics that do not scratch their body. Cotton or polyester cotton blends provide comfort, durability, and easy care for fabrics of babywear.

Moisture management properties of the fabrics are among the most important parameters that determine the wearer's comfort perception. Sweat transmission and absorption properties of garment are affected by fiber properties, yarn and fabric structural parameters, chemical processing and clothing design properties.

In this study, the effect of cotton knitted fabrics structure fabric weight, fabric thickness, weave type and yarn count of babywear on moisture management properties was investigated.

It has been tested that different knitted structures have different comfort properties. The fabric structure properties influence moisture transfer properties.

In this study single jersey fabric sample (A6) had an "excellent" accumulative one-way transport capability (OWTC) and overall moisture management capability $(\mathrm{OMMC})$ values. Also single jersey fabric wetting time, absorption rate and spreading speed were very fast.

On the other hand, single jersey fabric should be chosen for babywears for better moisture management properties.

Interlock fabric samples (A3) and (A4) had "very good" accumulative one-way transport capability (OWTC) overall moisture management capability (OMMC) values.

Statistical analysis showed that yarn count and knitted fabric type had an effect on moisture management 
properties. It was seen that the spreading speed, OWTC and OMMC values increased as yarn thickness, fabric weight and fabric thickness decreased. A positive correlation was observed between fabric weight, fabric thickness and wetting time. But at the same time negative correlations were observed between fabric weight, fabric thickness and absorption rate, spreading speed, OWTC and OMMC values.

\section{ACKNOWLEDGEMENTS}

The authors thank to Kity Kate Babywear Company-Bursa for their contribution for this study.

\section{REFERENCES}

[1] Vimala, M., Ramalakshmi, P., Designing comfort garment for children, In: The Indian Textile Journal, 2008, 119, 3, 31-38

[2] Ashour, N.S., Hamdaoui, S., Nasrallah, B., Perwuelz, A., Investigation of moisture management properties of cotton and blended knitted fabrics, In: International Journal of Materials and Metallurgical Engineering, 2015, 9, 7, 891-895

[3] Maqsood, M., Hussain, T., Malik, M.H., Nawab, Y., Modeling the effect of elastane linear density, fabric thread density and weave float on the stretch, recovery and compression properties of bi-stretch woven fabrics for compression garments, In: The Journal of the Textile Institute, 2016, 107, 307-315

[4] Chinta, S.K., Gujar, P.D., Significance of moisture management for high performance textile fabrics, In: International Journal of Innovative Research in Science Engineering and Technology, 2013, 2, 814-819

[5] Hu, J.Y., Li, Y.I., Yeung, K.W., Liquid moisture transfer, In: Clothing Biosensory Engineering, Woodhead Publishing, Cambridge, UK, 2006

[6] Hu, J., Li, Y., Yeung, K.W., Wong, A.S.W., Xu, W., Moisture management tester: A method to characterize fabric liquid moisture management properties, In: Textile Research Journal, 2005, 75, 1, 57-62

[7] http://www.sdl.atlas.com SDL Atlas MMT Moisture Management Tester. (Accessed 12 February 2018)

[8] Venkatesh, J., Gowda, K.N.N., Effect of plasma treatment on the moisture management properties of regenerated bamboo fabric, In: International Journal of Scientific and Research Publications, 2013, 3, 1-8

[9] ASTM D 3776-09a, Standard test method for mass per unit area (weight) of fabric, Annual Book of ASTM Standards, USA, 2017

[10] ASTM D 1777-96, Standard test method for thickness of textile materials, Annual Book of ASTM Standards, USA, 2007

[11] AATCC Test Method 195, Liquid moisture management properties of textile fabrics, USA, 2012

[12] Supuren, G., Oglakcıoglu, N., Ozdil, N., Marmaralı, A., Moisture management and thermal absorptivity properties of double-face knitted fabrics, In: Textile Research Journal, 2011, 81, 13, 1320-1330

[13] Yao, B., Li, Y.,Hu, J.,Kwok, Y., Yeung, K., An improved test method for characterizing the dynamic liquid moisture transfer inporous polymeri, In: Polymer Testing, 2006, 25, 5, 677-689

[14] Kara, G., Akgun, M., Effect of weft yarn fiber content on the moisture management performance of denim fabrics woven with different constructional parameters, In: Textile and Clothing, 2018, 28, 2, 151-161

[15] Oner, E., Atasagun, H.G., Okur, A., Beden A.R., Durur, G., Evaluation of moisture properties on knitted fabrics, In: The Journal of The Textile Institute, 2013, 104, 7, 699-707

[16] Zahra, Q., Mangat, A.E., Fraz, A., Hussain, S., Abbas, M., Mukhtar, U., Air moisture and thermal comfort properties of woven fabrics from selected yarns, In: Industria Textila, 2018, 69, 3, 177-182, https://doi.org/10.35530/ IT.069.03.1447

\section{Authors:}

\section{SERAP BILTEKIN ${ }^{1}$, AYÇA GURARDA²}

${ }^{1}$ Uludag University, Institute of Natural Sciences, Textile Engineering Department, Gorukle, Bursa, Turkey, e-mail: serap.biltekin16@gmail.com

2Uludag University, Faculty of Engineering, Textile Engineering Department, Gorukle, Bursa, Turkey, e-mail: aycagur@uludag.edu.tr

\section{Corresponding author:}

\section{AYÇA GURARDA}

e-mail: aycagur@uludag.edu.tr 


\section{Development of floating treatment wetlands with plant-bacteria partnership to clean textile bleaching effluent}

DOI: $10.35530 / 1 T .070 .06 .1679$

\author{
MUHAMMAD TUSIEF QAMAR \\ HUSSAN MALIK MUMTAZ \\ MUHAMMAD MOHSIN
}

\author{
HAFIZ NAEEM ASGHAR \\ MUHAMMAD IQBAL \\ MAHMOOD NASIR
}

\section{ABSTRACT - REZUMAT \\ Development of floating treatment wetlands with plant-bacteria partnership to clean textile bleaching effluent}

Treatment of textile wastewater prior to its discharge into the environment is a highly concerned issue of the industry. The current established methods in textile industry for effluent treatment are typically high in cost, require range of chemicals along with the generation of concentrated hazardous sludge. It is therefore inevitable to look for economical and eco-friendly ways to treat textile wastewater. Hence, the present study was endeavored to develop green, chemical free and sustainable bacteria inoculated plant based technique for remedying textile bleaching effluents. A lab scale floating treatment wetlands (FTWs) system was developed and implemented for remediation of $\mathrm{H}_{2} \mathrm{O}_{2}$ based textile bleaching wastewater. This system was designed by vegetating two free floating aquatic plants Eichhorniacrassipes and Pistia stratiotes. The performance of this system was enhanced by inoculating two pollutant degrading and plant growth promoting bacteria, Bacillus cereus and Bacillus subtilis. The efficacy of this bacterial augmented FTWs system was assessed by monitoring physicochemical parameters of treated wastewater. A substantial decrease in pH, EC, TDS, TSS, BOD and COD was noted. This stamped the effectiveness of this sustainable technique to treat textile effluents.

Keywords: waste water treatment, textile bleaching effluent, floating treatment wetlands, plant-bacteria synergy, plant growth promoting bacteria

\section{Sistem plutitor bazat pe sinergia plante-bacterii pentru tratarea efluenților rezultați din tratamentul de albire al materialelor textile}

Tratarea apelor uzate textile înainte de evacuarea acestora în mediu este o problemă extrem de importantă pentru industrie. Metodele actuale existente în industria textilă pentru tratarea efluenților au de obicei costuri ridicate și necesită o serie de substanțe chimice, generând nămoluri active poluante. Prin urmare, este necesară identificarea unor modalități economice și ecologice pentru tratarea apelor uzate rezultate din finisajul textil. Studiul de față are ca obiectiv dezvoltarea unei metode ecologice și sustenabile, bazate pe sinergia plante-bacterii, pentru tratarea efluenților rezultați din procesul tehnologic de albire al materialelor textile. La nivel de laborator, a fost dezvoltat și implementat un sistem plutitor de tratarea efluenților (FTW) rezultați din procesul tehnologic de albire a materialelor textile pe bază de $\mathrm{H}_{2} \mathrm{O}_{2}$. Acest sistem a fost proiectat prin cultivarea a două plante acvatice plutitoare, respectiv Eichhorniacrassipes și Pistiastratiotes. Performanța acestui sistem a fost îmbunătățită prin inocularea a două bacterii, care degradează poluanții și care favorizează creșterea plantelor, respectiv Bacillus cereus și Bacillus subtilis. Eficacitatea acestui sistem FTW augumentat cu bacterii a fost evaluată prin monitorizarea parametrilor fizico-chimici ai apelor uzate tratate. S-a observat o scădere substanțială a pH-ului, EC, TDS, TSS, BOD și COD. Acest lucru a permis evaluarea eficienței acestei metode sustenabile de tratarea efluenților rezultați din finisajul textil.

Cuvinte-cheie: tratarea apelor uzate, efluenți finisaj textil, tehnologie plutitoare, sinergie plante-bacterii, bacterii pentru creșterea plantelor

\section{INTRODUCTION}

Textile industry plays significant role to boost up the economy of developing and developed countries [1], nevertheless, effluents generated by textile wet processing sector is responsible for massive destruction of aquatic ecology [2]. Moreover, the presence of organic and inorganic ingredients in receiving water bodies leads to reduce the sunlight penetration in them which directly disrupt the photosynthetic activity and concentration of dissolved oxygen [3]. The environmental and aquatic pollution caused by textile wet processing (TWP) industry is because of the release of its effluents directly to nearby drains without treatment or partial treatment especially in developing countries. These effluents have high values of $\mathrm{pH}$, suspended and dissolved solids, biological oxygen demand (BOD), chemical oxygen demand (COD), and other pollutants [4-5]. A typical textile wet processing comprises a series of processes like pretreatment, dyeing and finishing [6]. Bleaching is the most significant pre-treatment process carried out prior to dyeing for removing colouring impurities and to increase the fabric whiteness. Bleaching has to be performed on all fabrics whether sold as white or 
coloured. Among other bleaching agents like sodium hypochlorite, hydrogen peroxide has dominant share in industrial bleaching process [7]. It has been found that $38 \%$ of water in textile wet processing industry is used during bleaching process [8]. So a huge magnitude of wastewater is released from the bleaching process. Approximately 70 billion tons of wastewater is generated every year by textile industry [9]. Treatment of textile wastewater prior to its discharge into naturally occurring water bodies is highly desirable.

Many physicochemical and biological techniques like filtration, adsorption, coagulation, flocculation, oxidation and electrochemical methods are being exercised to treat textile wastewater. However, these methods have limitations with respect to operational and maintenance cost, requirement of skilled man power and generation of hazardous sludge that creates huge problem of its safe disposal [4]. In comparison to these capital and labour intensive physicochemical ways, bioremediation is an eco-friendly, less expensive and handy approach to clean textile wastewater from both organic and inorganic pollutants. It is based on plants, microbes and their partnership for wastewater treatment. In this technique bacteria boosts up the plant growth due to catabolism. In return plants provide nutrients, metabolites and habitats to microbes in their (endo)rhizoshpere. This plant-bacteria synergistic interaction results in enhanced degradation of hydrocarbons containing pollutants [10]. In this partnership plants contribute towards phyto-extraction, phytovolatilization, phytouptake, phytodegradation, rhizofiltration, phytostabilization (figure 1) while microbes take part in plant growth promotion activities and metabolization of organic pollutants and mineralization of inorganic pollutants. The application of this plant-microbe interactive mechanism has been suggested as an efficient mean to treat many kinds of wastewater and considered to have in situ applicability [11].

Floating treatment wetlands (FTWs) technique, being economical and low energy consuming, provide a green solution to clean polluted water. This method has been successfully applied to treat municipal, sewage, storm, domestic, industrial and poultry processing wastewater [12-17] while efficacy of constructed wetlands have been explored for general textile water [18]. However, to the best of our knowledge, floating treatment wetlands, vegetating with free floating aquatic plants, has not been assessed until now for cleaning textile bleaching enriched wastewater. Hence the current study has been conducted to remediate $\mathrm{H}_{2} \mathrm{O}_{2}$ enriched bleaching water of textile industry applying plant-microbe augmented FTWs technique.

\section{MATERIAL AND METHODS}

\section{Collection of plants and development of their nursery}

Plant selection for this technique is of utmost importance. The plants having dense root system are preferable for phytoremediation. In addition, native plants are more favorable to use as they are better tolerant to existing climate conditions. Therefore, two local plants which are found in abundance in the surroundings of Lahore and Faisalabad (the textile industry hub in Pakistan) "Eichhorniacrassipes (Water hyacinth)and Pistia stratiotes (Water lettuce)", were selected for the present research study. Adult plants were collected from local water bodies and stored in water tubs of circular shape having $76 \mathrm{~cm}$ diameter and $30 \mathrm{~cm}$ depth under ambient conditions for the development of their nursery (figure 2). In order to survive in textile wastewater they were immuned by feeding them with the textile wastewater for one week with increasing ratio of tap water and textile

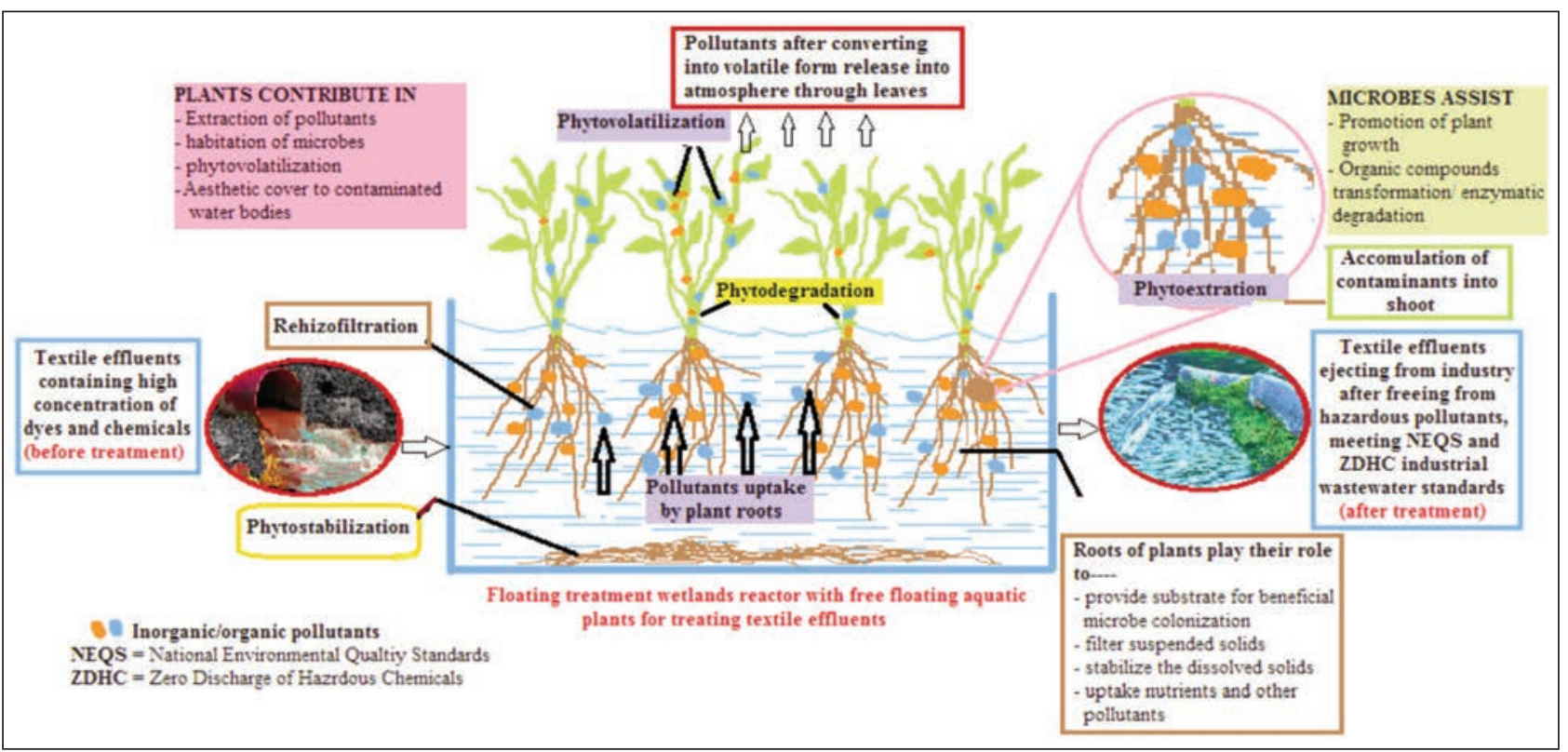

Fig. 1. Schematic view of FTW based phytoremediation mechanism proposed for the remediation of textile bleaching effluents 


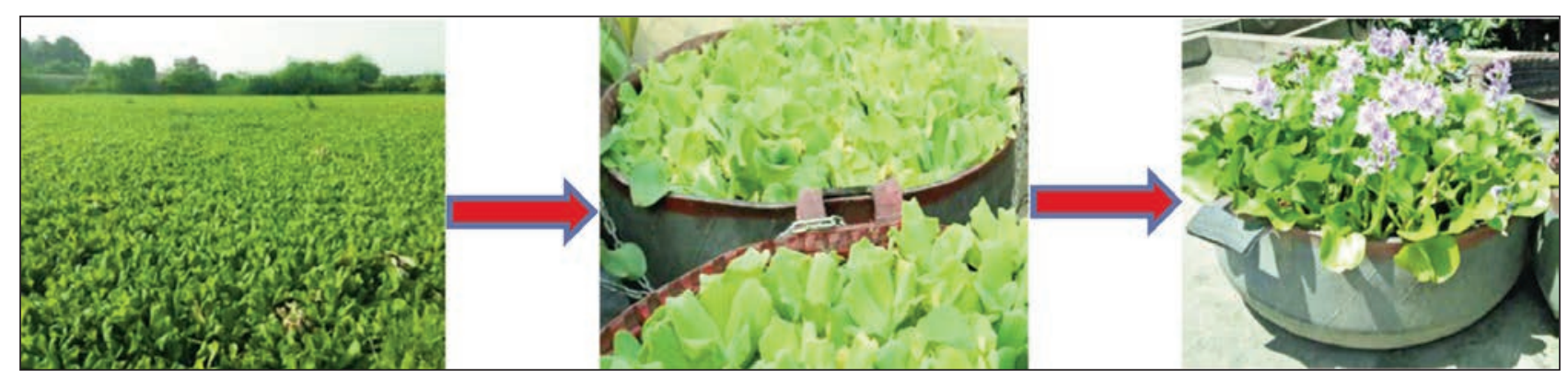

Fig. 2. Plants collection, their storage in tubs and development of their nursery

wastewater i.e. 0:100, 20:80, 40:60, 60:40, 80:20 and $100: 0$ respectively. After getting immunity the plants flourished well in pure textile wastewater and increased their population to double within 10 days.

\section{Collection of wastewater degrading bacterial strains}

Previously isolated and characterised [19] pollutant degrading bacterial strains, "Bacillus cereus" and "Bacillus subtilis", were selected and developed using general purpose agar media (glucose peptone agar media) applying dilution plate technique. Inoculation of media plates was made with soil solution and these plates were then incubated at $28 \pm 2^{\circ} \mathrm{C}$ for 72 hours. From each soil sample the colony farming units (CFU/g soil) were calculated. The isolates of bacteria were examined for their polycyclic aromatic hydrocarbon biodegrading prospective using BushnellHaas broth in 24-well microtiter plates [20]. The efficacy of these bacterial isolates for plant growth promoting was also verified by testing their ACC-deaminase activity through method described by Jacobson [21]. Performance evaluation of these bacterial strains in respect to their textile effluent degradation and plant growth promotion activities has also been acknowledged in many other studies [22-23].

\section{Hydrogen per oxide $\left(\mathrm{H}_{2} \mathrm{O}_{2}\right)$ enriched bleaching} solution preparation

The bleaching solution of $0.2 \%$ concentration was prepared according to the recipe; Hydrogen per oxide $\left(\mathrm{H}_{2} \mathrm{O}_{2}\right)$ [50\% concentrated solution] and Sodium carbonate $\left(\mathrm{Na}_{2} \mathrm{CO}_{3}\right) 0.6 \mathrm{~g} / \mathrm{L}$.

\section{Designing and development of FTWs}

FTWs system was designed in transparent polyethylene containers $(39 \mathrm{~cm} \times 28 \mathrm{~cm} \times 20 \mathrm{~cm})$ of 10 liter capacity. Lab scale treatment reactors were developed for this research in order to evaluate the performance of the selected plants and bacterial strains for remediation of $\mathrm{H}_{2} \mathrm{O}_{2}$ enriched bleaching water. Nine treatment reactors for each color were developed. Their details are given below:

$\mathrm{C}=$ control (only bleaching solution)

$\mathrm{T} 1$ = solution + P1 (plant 1; Eichhoriniacrassipes)

$\mathrm{T} 2=$ solution $+\mathrm{P} 1+\mathrm{B} 1$ (bacteria $1 ;$ Bacillus cereus)

$\mathrm{T} 3$ =solution + P1 + B2 (bacteria 2; Bacillus subtilis)

$\mathrm{T} 4$ = solution + P2 (plant 2; Pistiastratiotes)

$\mathrm{T} 5=$ solution $+\mathrm{P} 2+\mathrm{B} 1$

$\mathrm{T} 6=$ solution $+\mathrm{P} 2+\mathrm{B} 2$

$\mathrm{T} 7=$ solution $+\mathrm{B} 1$

$\mathrm{T} 8=$ solution $+\mathrm{B} 2$

The reactors according to the above cited details were developed by vegetating 5 plants of each type having nearly equal mass in transparent polyethylene containers. Before vegetation the plants roots were thoroughly washed. After this the selected bacterial strains were inoculated in these containers according to the designed specifications of the reactors. For the development of plant-bacteria interaction, the plants were dipped in $500 \mathrm{ml}$ broth of each bacterium for 40 minutes. Then these plants were transferred to each treatment reactor (figure 3).

\section{Testing of textile effluents}

$500 \mathrm{ml}$ sample was taken from each reactor after four retention time intervals (TM1 0 hours, TM2 24 hours, TM3 48 hours and TM4 72 hours) in transparent plastic bottles after washing them thoroughly with distilled water and analysis were performed for examining
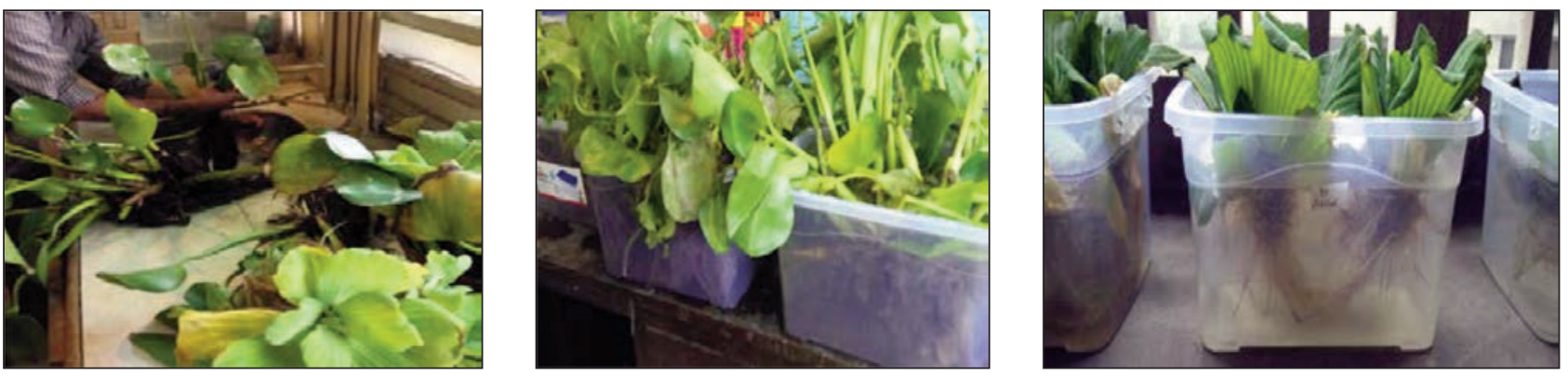

Fig. 3. Washing of plant's roots before vegetation and development of treatment reactors 
the effects of selected treatments and retention times on physicochemical parameters i.e. pH, EC (electric conductivity), TDS (total dissolved solids), TSS (total suspended solids), $\mathrm{BOD}_{5}$ (biological oxygen demand) after five days, COD (chemical oxygen demand) for hydrogen per oxide enriched bleaching wastewater, table 1, according to standard procedures [24].

Table 1

\begin{tabular}{|c|c|}
\hline \multicolumn{2}{|c|}{$\begin{array}{c}\text { APHA STANDARD METHODS USED TO EXAMINE } \\
\text { THE WASTEWATER QUALITY PARAMETERS }\end{array}$} \\
\hline Parameter & APHA method \\
\hline $\mathrm{pH}$ & Method 4500-H+B \\
\hline Electric conductivity (EC) & Method 2510 \\
\hline Chemical oxygen demand (COD) & Method 5220 D \\
\hline Biological oxygen demand (BOD) & Method 5210 D \\
\hline Total dissolved solids (TDS) & Method 2540 C \\
\hline Total suspended solids (TSS) & Method 2540 D \\
\hline
\end{tabular}

\section{Statistical analysis}

The statistical tests were conducted using the SAS program version STAT 9.1 of SAS Institute [25]. All the selected water quality parameters were analyzed employing General Linear Model (GLM) whereas multiple comparisons were made using the least significant difference (LSD) test for differences between means. A significance level of $p<0.05$ was used for all statistical tests. Furthermore, regression analysis was also carried out in order to analyze the effect of time on quality parameters of textile wastewater.

\section{RESULTS AND DISCUSSION}

$\mathrm{pH}$ value of wastewater as affected by various treatments and hydraulic retention times

LSD (least significant difference) test along with comparison of individual treatment means of $\mathrm{pH}$ value for variant retention times are presented in table 2 . The results reflect significantly ( $\alpha=0.05)$ highest value of $\mathrm{pH}$ along column wise for control treatment $\mathrm{C}$ (9.64) and lowest for treatment T2 (9.30). Similarly along row wise the greatest value of $\mathrm{pH}$ was noted for retention time TM1 (9.87) while lowest value was observed for retention time TM4 (9.22). These findings clearly indicate a good reductionof $8.8 \%$ in $\mathrm{pH}$ value (figure $4, a$ ) of the solution for reactor T2 (Bacillus cereus + Eichhorniacrassipes) at retention time TM4 (72 hours) when compared with that of control reactor $(\mathrm{C})$. These results exhibit considerable effect of Eichhorniacrassipes and Bacillus cereus in synergy to reduce $\mathrm{pH}$ of the bleaching solution.

The analysis of variance (ANOVA) for regression with respect to time (table 3 ) for bleaching solution disclosed a significant impact $(\alpha=0.05)$ on the reduction of $\mathrm{pH}$ of the solution. The regression model so developed narrated an inverse affect of time on the $\mathrm{pH}$ values at the rate of 0.009 . There came high degree of certainty $\left(r^{2}=0.67\right)$ that ensured the best representation of the data observed by the predicted equation (1).

$$
\mathrm{pH}=9.74-0.009 \times \mathrm{TM}
$$

It is derived from all the above findings that interactive action of Eichhorniacrassipes and Bacillus cereusis responsible for greater reduction in $\mathrm{pH}$ of bleaching solution and bringing it towards neutral side matching with the standards set by for industrial wastewater. This reduction in $\mathrm{pH}$ from alkaline side towards neutral is due to the production of carbonic acid in solution as a result of degradation of organic pollutants in the effluents. Similar conclusions were also predicted in previous studies [26-27] for nonbleach processes. Additionally the bacterial addition in this system enhanced the performance of this mechanism by promoting the growth of the plants resulting in their ability to take up contaminants. Moreover, rise in the degradation of organic pollutants

\begin{tabular}{|c|c|c|c|c|c|c|}
\hline \multicolumn{7}{|c|}{ EFFECT OF VARIOUS TREATMENTS (T) AND TIME (TM) ON PH VALUE OF BLEACHING SOLUTION } \\
\hline \multirow{2}{*}{ Treatment } & \multicolumn{4}{|c|}{$\mathrm{pH}$} & \multirow{2}{*}{ Mean } & \multirow{2}{*}{ LSD (0.05) } \\
\hline & TM1 & TM2 & TM3 & TM4 & & \\
\hline C & $9.89^{a}{ }_{a}$ & $9.59_{\mathrm{b}}{ }^{\mathrm{a}}$ & $9.55_{b c}^{a}$ & $9.51_{c}^{a}$ & $9.64 \mathrm{a}$ & 0.0580 \\
\hline T1 & $9.88_{a}^{a}$ & $9.37_{\mathrm{b}}^{\mathrm{c}}$ & $9.28_{c}{ }^{c}$ & $9.23_{\mathrm{C}}{ }^{\mathrm{c}}$ & $9.44_{c}$ & 0.0580 \\
\hline $\mathrm{T} 2$ & $9.86_{a}^{a}$ & $9.25_{b}{ }^{d}$ & $9.08_{c}{ }^{f}$ & $9.02_{c}^{f}$ & $9.30_{f}$ & 0.0632 \\
\hline T3 & $9.87_{a}^{a}$ & $9.31_{b}{ }^{c d}$ & $9.20_{C}$ de & $9.16_{c}$ de & $9.39_{\mathrm{de}}$ & 0.0595 \\
\hline T4 & $9.87_{a}^{a}$ & $9.47 b^{b}$ & $9.39_{b c}^{b}$ & $9.33_{c}^{b}$ & $9.52_{b}$ & 0.0873 \\
\hline T5 & $9.85_{a}^{a}$ & $9.30_{b}{ }^{c d}$ & $9.18_{c}{ }^{e}$ & $9.13_{c}^{e}$ & $9.37_{e}$ & 0.0685 \\
\hline T6 & $9.86_{\mathrm{a}}{ }^{a}$ & $9.36_{b}{ }^{c}$ & $9.24_{c}$ cde & $9.18_{c}^{\text {cde }}$ & $9.41_{\mathrm{cd}}$ & 0.0692 \\
\hline T7 & $9.86_{a}^{a}$ & $9.33_{b}{ }^{c}$ & $9.26_{b c}{ }^{c d}$ & $9.20_{C}{ }^{c d}$ & $9.41_{\mathrm{cd}}$ & 0.0873 \\
\hline T8 & $9.88_{a}^{a}$ & $9.35_{b}{ }^{c}$ & $9.27_{b c}{ }^{c}$ & $9.22_{c}{ }^{c d}$ & $9.43_{c}$ & 0.0873 \\
\hline Mean & $9.87^{a}$ & $9.37^{b}$ & $9.27^{c}$ & $9.22^{d}$ & 9.43 & 0.0207 \\
\hline LSD (0.05) & 0.0586 & 0.0756 & 0.0611 & 0.0657 & 0.0311 & \\
\hline
\end{tabular}

Superscripts ( $a, b, c, d, e, f)$ showed comparison among means vertically in columns and subscripts showed comparison among means horizontally along rows. Any two values not sharing a letter in common differ significantly at $p<0.05$. 
ANOVA FOR REGRESSION ANALYSIS FOR TIME FOR BLEACHING SOLUTION

\begin{tabular}{|c|c|c|c|c|c|c|c|c|c|c|c|c|c|}
\hline \multirow{2}{*}{ Source } & \multirow{2}{*}{ DF } & \multicolumn{2}{|c|}{ Dep. Var. pH } & \multicolumn{2}{|c|}{ Dep. Var. EC } & \multicolumn{2}{|c|}{ Dep. Var. TDS } & \multicolumn{2}{|c|}{ Dep. Var. TSS } & \multicolumn{2}{|c|}{ Dep. Var. BOD } & \multicolumn{2}{|c|}{ Dep. Var. COD } \\
\hline & & MS & $P>F$ & MS & $P>F$ & MS & $P>F$ & MS & $P>F$ & MS & $P>F$ & MS & $P>F$ \\
\hline Model & 1 & 5.6427 & 0.0001 & 45.3618 & 0.0001 & 10069607 & 0.0001 & 26882 & 0.0001 & 6283.27 & 0.0001 & 6636.02 & 0.0001 \\
\hline Error & 106 & 0.0260 & & 0.4063 & & 115907 & & 253.5377 & & 24.4660 & & 45.1909 & \\
\hline $\begin{array}{l}\text { Corr } \\
\text { Total }\end{array}$ & 107 & & & & & & & & & & & & \\
\hline
\end{tabular}

by these bacteria is due to their metabolic properties that results in release of organic acids which reduced the $\mathrm{pH}$ of the solution.

\section{Effect of various treatments and hydraulic} retention time on EC value of bleaching solution The results presented in table 4 regarding the comparison of individual mean values of EC was analyzed statistically by applying LSD test. It indicates significantly ( $\alpha=0.05)$ greatest value of EC (4.99 $\mathrm{dS} / \mathrm{m}$ ) along column wise for control treatment (C). While the lowest value of EC (3.80 dS/m) along row wise was noted for T2 treatment. Similarly for various retention times the greatest value of EC (5.42 dS/m) along row wise was observed for TM1 while lowest value of EC (3.51 dS/m) was noted for TM4.

The ANOVA for regression (table 3 ) related to time disclosed a significant $(\alpha=0.05)$ effect of retention time on the EC value of the solution. The developed regression model indicated an inverse effect of time on EC value at the rate of 0.024 . The degree of certainty was found higher $\left(r^{2}=0.51\right)$ clearly indicating the best representation of data by the predicted equation (2)

$$
\mathrm{EC}=4.88-0.024 \times \mathrm{TM}
$$

All these findings clearly exhibit the dominant effect of Eichhorniacrassipes and Bacillus cereus synergy to reduce $\mathrm{EC}$ value of the solution as compared to that of other treatment combinations. Maximum reduction in EC value of $40.63 \%$ was observed for this combination (T2) (figure 4,b). This decrease in EC value of bleaching solution under the plant-bacteria partnership is attributed towards the decrease of soluble salts that might be taken up by the plant through its root and shoot system. Similar decrease in EC was also reported previously for non-textile application [28]. Basically plants provide habitat to bacteria and in return bacteria add up the plant growth due to their catabolic activities which improves the nutrient up take ability of plants through their root and shoots. This plant-microbe combination enhanced the reduction of EC value of wastewater.

\section{Effect of various treatments and hydraulic retention time on TDS value of bleaching solution}

The statistical analysis of data regarding TDS value of the bleaching solution, table 5 , clearly indicates the significant $(\alpha=0.05)$ effect of selected treatments on TDS. The comparison of individual treatment reflects highest value of TDS along column wise for control treatment C $(2737 \mathrm{mg} / \mathrm{L})$ while the lowest value for treatment T2 $(1958 \mathrm{mg} / \mathrm{L})$. In the same line the greatest TDS value was noted for TM1 (2809 mg/L) while lowest value was recorded for TM4 (1911 mg/L) along row wise.

The analysis of data applying regression analysis (table 3 ) described significant $(\alpha=0.05)$ effect of time

\begin{tabular}{|c|c|c|c|c|c|c|}
\hline \multicolumn{7}{|c|}{ EFFECT OF VARIOUS TREATMENTS (T) AND TIME (TM) ON EC VALUE OF BLEACHING SOLUTION } \\
\hline \multirow{2}{*}{ Treatment } & \multicolumn{4}{|c|}{ EC } & \multirow{2}{*}{ Mean } & \multirow{2}{*}{ LSD (0.05) } \\
\hline & TM1 & TM2 & TM3 & TM4 & & \\
\hline C & $5.44_{a}^{a}$ & $4.89_{b}^{a}$ & $4.83_{c}^{a}$ & $4.80_{c}{ }^{a}$ & $4.99_{a}$ & 0.0541 \\
\hline T1 & $5.43^{a}$ & $3.49_{b}^{b c}$ & $3.43_{b c}^{b c}$ & $3.41_{c}^{b c}$ & $3.94_{b c}$ & 0.0692 \\
\hline T2 & $5.40 a^{a}$ & $3.33_{b}{ }^{f}$ & $3.27_{c}^{f}$ & $3.23_{c}^{f}$ & $3.80_{f}$ & 0.0580 \\
\hline T3 & $5.42 a^{a}$ & $3.39_{b}$ ef & $3.34_{b c}$ de & $3.31_{c}$ de & $3.87_{\mathrm{e}}$ & 0.0541 \\
\hline T4 & $5.44 a^{a}$ & $3.51_{\mathrm{b}}^{\mathrm{b}}$ & $3.46_{b c}^{b}$ & $3.43_{c}^{b}$ & $3.96_{b}$ & 0.0610 \\
\hline T5 & $5.41_{a}^{a}$ & $3.40_{b}$ de & $3.31_{c}$ ef & $3.29_{c}{ }^{e}$ & $3.85_{e}$ & 0.0645 \\
\hline T6 & $5.43_{\mathrm{a}}^{\mathrm{a}}$ & $3.43_{b}$ de & $3.39_{b c}{ }^{c d}$ & $3.36_{c}^{c d}$ & $3.90_{d}$ & 0.0541 \\
\hline T7 & $5.41_{a}^{a}$ & $3.46_{b}^{b c d}$ & $3.40_{c}{ }^{c}$ & $3.37_{c}^{c}$ & $3.91_{d}$ & 0.0541 \\
\hline T8 & $5.42^{a}$ & $3.48_{b}^{b c}$ & $3.41_{b c}{ }^{b c}$ & $3.39_{c}^{b c}$ & $3.93_{\mathrm{cd}}$ & 0.0810 \\
\hline Mean & $5.42^{a}$ & $3.60^{b}$ & $3.54^{\mathrm{c}}$ & $3.51^{d}$ & 4.02 & 0.0178 \\
\hline LSD (0.05) & 0.0428 & 0.0654 & 0.056 & 0.0583 & 0.0267 & \\
\hline
\end{tabular}


EFFECT OF VARIOUS TREATMENTS (T) AND TIME (TM) ON TDS VALUE OF BLEACHING SOLUTION

\begin{tabular}{|c|c|c|c|c|c|c|}
\hline \multirow{2}{*}{ Treatment } & \multicolumn{4}{|c|}{ TDS } & \multirow{2}{*}{ Mean } & \multirow{2}{*}{ LSD (0.05) } \\
\hline & TM1 & TM2 & TM3 & TM4 & & \\
\hline C & $2810^{a}$ & $2747_{b}^{a}$ & $2701_{c}^{a}$ & $2689_{d}^{a}$ & $2737_{a}$ & 5.4081 \\
\hline $\mathrm{T} 1$ & $2809_{a}^{a}$ & $1920_{b}{ }^{c}$ & $1909_{\mathrm{c}}^{\mathrm{bc}}$ & $1906_{c}^{b}$ & $2136_{c}$ & 6.9180 \\
\hline T2 & $2808^{a}$ & $1700_{b}{ }^{f}$ & $1669_{\mathrm{c}} \mathrm{g}$ & $1656_{c}^{f}$ & $1958_{g}$ & 14.7960 \\
\hline T3 & $2808^{a}$ & $1860_{b}^{d}$ & $1815_{c}^{e}$ & $1797_{c}^{d}$ & $2070_{\mathrm{e}}$ & 19.7250 \\
\hline T4 & $2810^{a}$ & $1968_{b}^{b}$ & $1911_{c}^{b}$ & $1903_{c}^{b}$ & $2148_{b}$ & 19.2930 \\
\hline T5 & $2808_{a}^{a}$ & $1760_{b}^{e}$ & $1695_{C}{ }^{f}$ & $1683_{c}^{e}$ & $1987_{f}$ & 15.1800 \\
\hline T6 & $2809_{a}^{a}$ & $1867_{b}^{d}$ & $1823_{C}^{e}$ & $1800_{C}^{d}$ & $2075_{e}$ & 25.2080 \\
\hline T7 & $2809_{a}^{a}$ & $1913_{b}{ }^{c}$ & $1889_{C}{ }^{d}$ & $1883_{c}{ }^{c}$ & $2124_{d}$ & 19.6350 \\
\hline T8 & $2809_{a}^{a}$ & $1919_{b}{ }^{c}$ & $1893_{c}{ }^{c d}$ & $1886_{c}^{c}$ & $2127_{d}$ & 24.8190 \\
\hline Mean & $2809^{a}$ & $1962^{b}$ & $1923^{c}$ & $1911^{d}$ & 2151 & 5.1945 \\
\hline LSD (0.05) & 16.153 & 17.67 & 17.522 & 14.099 & 7.7918 & \\
\hline
\end{tabular}

on TDS value of the solution. The developed regression model in this respect indicated an inverse relation between time and TDS value at the rate of 11.38. The high degree of certainty $\left(r^{2}=0.45\right)$ ensures the best representation of the data observed by the predicted equation (3).

$$
\text { TDS }=2560.83-11.38 \times \mathrm{TM}
$$

It is obvious from the results that Eichhorniacrassipes and bacillus cereus combination under treatment T2 made significant reduction $(41.07 \%)$ in TDS value of bleaching solution after 72 hours retention time (figure $4, c)$. This substantial decrease in TDS is attributed to plant-bacteria partnership due which plant's roots provide more spaces for bacteria attachment. These spaces also motivate the adsorption and accommodation in plant tissues for both organic and inorganic matters while the bacteria presence enhance the efficacy of these processes due to its ability to degrade contaminants by transforming and mineralization.
Effect of various treatments and hydraulic retention time on TSS value of bleaching solution

Table 6 depicts significantly $(\alpha=0.05)$ greatest value of TSS (139 mg/L) along column wise at control treatment $\mathrm{C}$ and lowest $(98 \mathrm{mg} / \mathrm{L})$ at treatment $\mathrm{T} 2$. The overall mean value of TSS along row wise was noted greatest at retention time TM1 (140 mg/L) and lowest at retention time TM4 (96 mg/L).

The ANOVA, table 3, highlighted significant $(\alpha=0.05)$ impact of time on TSS value of the solution. The developed regression model in this respect showed inverse effect of time on TSS at the rate of 0.59 while the high degree of certainty $\left(r^{2}=0.50\right)$ made the best representation of data by the predicted equation (4).

$$
\text { TSS }=131.61-0.59 \times \text { TM }
$$

It is clear from all these facts that under the treatment T2 (Eichhorniacrassipes and Bacillus cereus) high reduction in TSS value (45.39\%) of bleaching solution was observed (figure $4, d$ ). This high level reduction

\begin{tabular}{|c|c|c|c|c|c|c|}
\hline \multicolumn{7}{|c|}{ EFFECT OF VARIOUS TREATMENTS (T) AND TIME (TM) ON TSS VALUE OF BLEACHING SOLUTION } \\
\hline \multirow{2}{*}{ Treatment } & \multicolumn{4}{|c|}{ TSS } & \multirow{2}{*}{ Mean } & \multirow{2}{*}{ LSD (0.05) } \\
\hline & TM1 & TM2 & TM3 & TM4 & & \\
\hline C & $141_{\mathrm{a}}^{\mathrm{a}}$ & $140 a^{a}$ & $138 a^{a}$ & $137 \mathrm{a}^{\mathrm{a}}$ & $1399_{a}$ & 6.92 \\
\hline T1 & $140^{a}$ & $110_{b}^{b}$ & $102_{c}^{b}$ & $99_{\mathrm{c}}^{\mathrm{bc}}$ & $113_{b c}$ & 5.80 \\
\hline T2 & $139^{a}$ & $94_{b}{ }^{d}$ & $81_{c}^{c}$ & $77_{c}^{e}$ & $98_{e}$ & 6.92 \\
\hline T3 & $140_{a}^{a}$ & $97_{b}^{c}$ & $86_{c}{ }^{e}$ & $81_{C}^{d e}$ & $101_{d}$ & 7.65 \\
\hline T4 & $140^{a}$ & $113_{b}^{b}$ & $105_{c}^{b}$ & $104_{c}^{b}$ & $116_{b}$ & 5.41 \\
\hline T5 & $139^{a}$ & $97_{b}^{c}$ & $87_{c}^{c}$ & $83_{C}$ de & $102_{d}$ & 6.92 \\
\hline T6 & $140_{a}^{a}$ & $99_{b}{ }^{c}$ & $88_{c}{ }^{c}$ & $85_{C}^{d}$ & $103_{d}$ & 8.73 \\
\hline T7 & $140^{a}$ & $108_{b}^{b}$ & $100_{c}^{b}$ & $97_{\mathrm{c}}^{\mathrm{c}}$ & $111_{\mathrm{c}}$ & 6.10 \\
\hline T8 & $140_{a}^{a}$ & $109_{b}^{b}$ & $101_{c}^{b}$ & $99_{\mathrm{C}}^{\mathrm{bc}}$ & $112_{c}$ & 5.80 \\
\hline Mean & $140^{a}$ & $107^{b}$ & $99^{c}$ & $96^{d}$ & 110 & 1.95 \\
\hline LSD (0.05) & 5.86 & 5.63 & 7.03 & 6.05 & 2.92 & \\
\hline
\end{tabular}




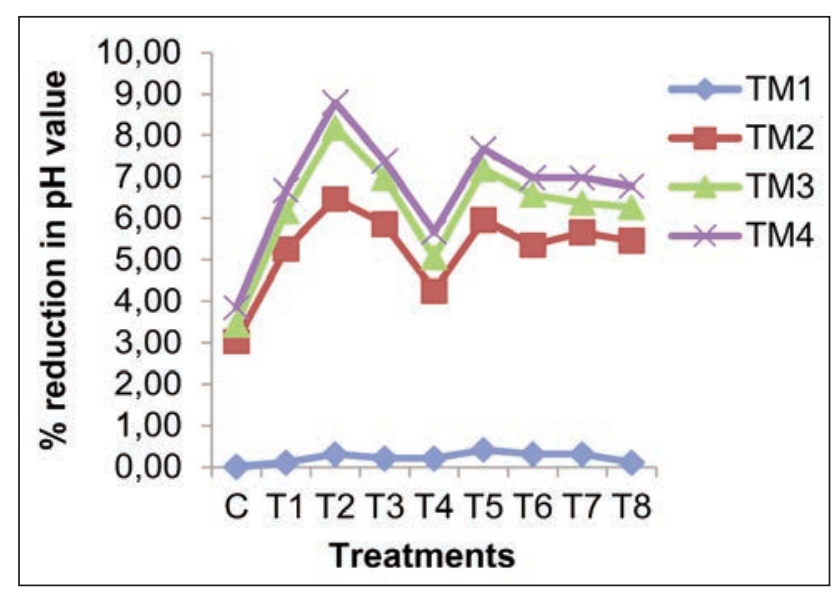

a

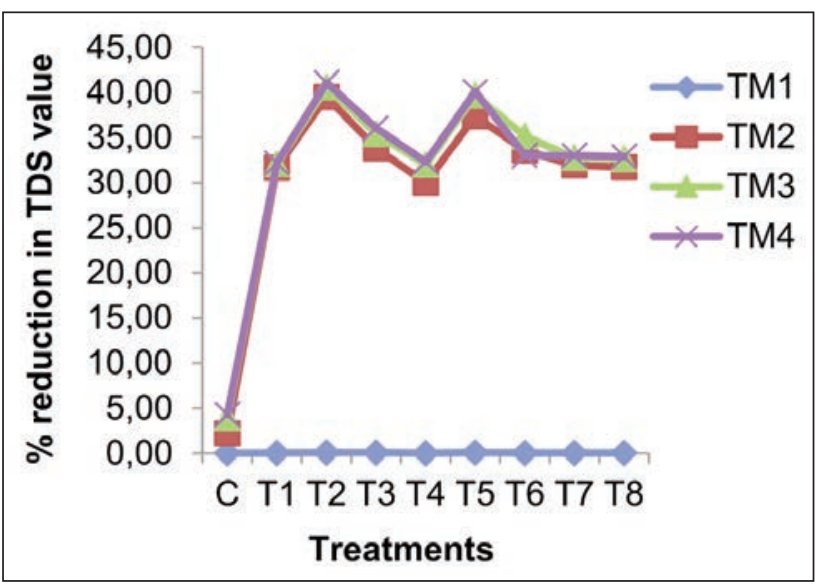

c

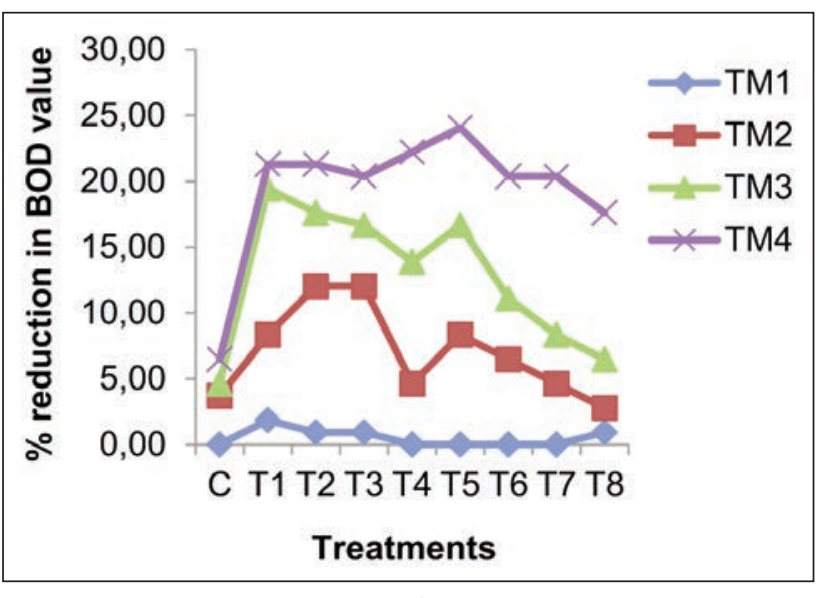

e
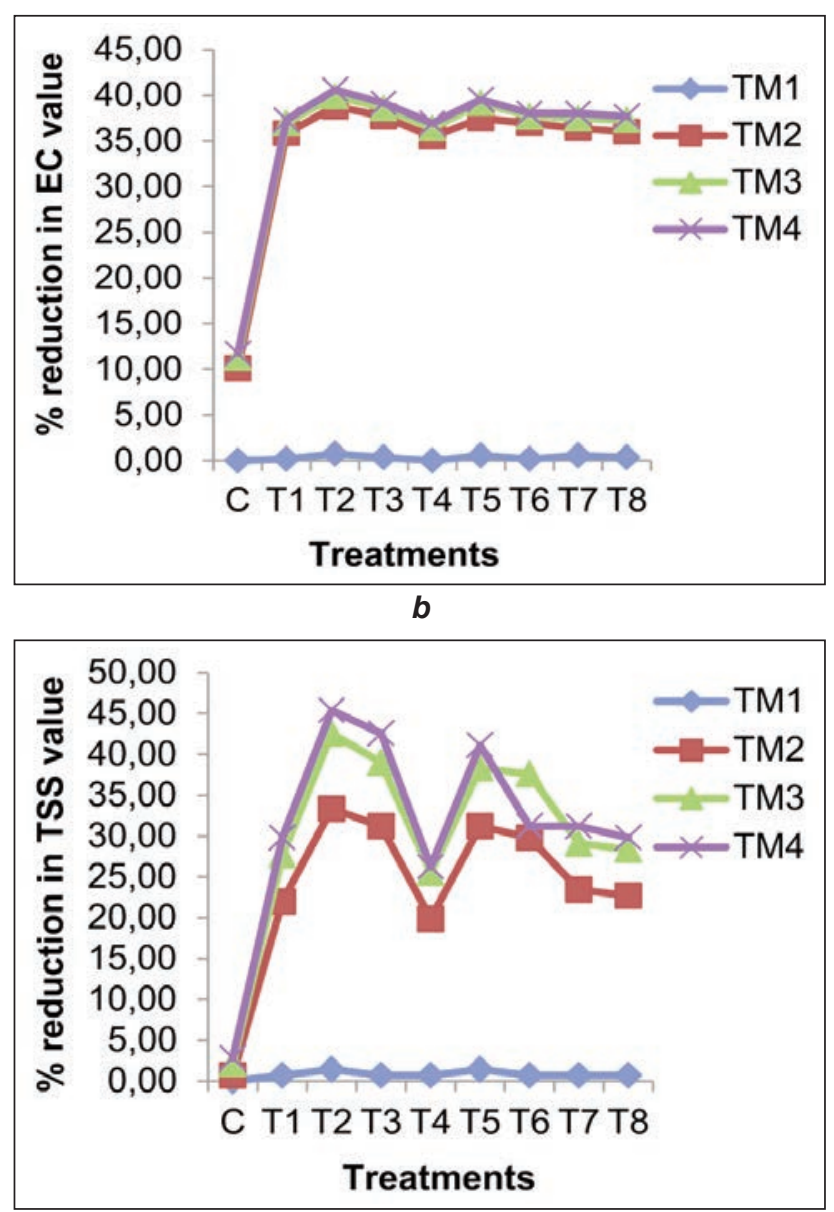
d

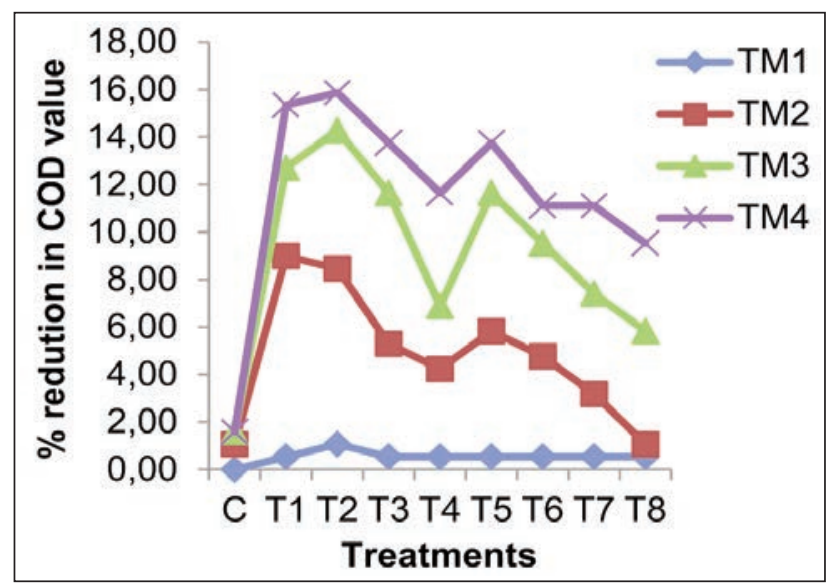

$f$

Fig. 4. Percentage ofreduction in physicochemical properties of bleaching solution for various treatments (T) and retention times (TM)

in TSS is accredited towards the dense root system of plants that makes availability of more places for filtering, settlement and trapping of suspended particles. Moreover, the presence of plant growth promoting and pollutant degrading bacteria enhanced this factor by boosting up plant's biomass.

Effect of various treatments and hydraulic retention time on BOD value of bleaching solution

The analysis of data demonstrated significant impact $(\alpha=0.05)$ of selected treatments on the BOD value of bleaching solution (table 7). Highest value BOD along column was recorded for control treatment $\mathrm{C}$ (104 mg/L) while lowest value was noted for treatment T2 (93 mg/L). Following the same trend along row, the highest value of BOD was reflected at time TM1 (107 mg/L) while lowest one was resulted for TM4 (87 mg/L).

The regression analysis of data exposed off an inverse impact of time on BOD value of the solution at the rate of 0.28 as shown in ANOVA, table 3. The high degree of certainty $\left(r^{2}=0.71\right)$ stamped the best presentation of the data observed by the predicted equation (5)

$$
\mathrm{BOD}=107.46-0.28 \times \mathrm{TM}
$$


EFFECT OF VARIOUS TREATMENTS (T) AND TIME (TM) ON BOD VALUE OF BLEACHING SOLUTION

\begin{tabular}{|c|c|c|c|c|c|c|}
\hline \multirow{2}{*}{ Treatment } & \multicolumn{4}{|c|}{ BOD } & \multirow{2}{*}{ Mean } & \multirow{2}{*}{ LSD (0.05) } \\
\hline & TM1 & TM2 & TM3 & TM4 & & \\
\hline C & $10 a^{a}$ & $104_{b}^{a b}$ & $103_{b}^{a}$ & $101_{b}{ }^{a}$ & $104_{a}$ & 3.65 \\
\hline T1 & $106_{a}^{a}$ & $99_{b}^{b c}$ & $87_{\mathrm{c}}^{\mathrm{e}}$ & $85_{c}^{b c}$ & $94_{\mathrm{e}}$ & 4.71 \\
\hline T2 & $107^{a}$ & $95_{b}{ }^{c}$ & $89_{\mathrm{C}}^{\mathrm{de}}$ & $82_{c}^{b c}$ & $93_{\mathrm{e}}$ & 4.98 \\
\hline T3 & $107_{a}^{a}$ & $95_{b}{ }^{c}$ & $90_{b c}$ de & $86_{c}^{b c}$ & $95_{e}$ & 5.41 \\
\hline T4 & $10 a^{a}$ & $103^{a b}$ & $93_{b}^{c d}$ & $85_{c}^{b c}$ & $97_{\mathrm{cd}}$ & 5.41 \\
\hline T5 & $108^{a}$ & $99_{b}^{b c}$ & $90_{C}^{d e}$ & $83_{d^{c}}$ & $95_{\mathrm{de}}$ & 6.92 \\
\hline T6 & $10 a^{a}$ & $101_{\mathrm{b}}^{\mathrm{ab}}$ & $96_{b}^{b c}$ & $84_{c}{ }^{c}$ & $97_{\mathrm{cd}}$ & 5.80 \\
\hline T7 & $108^{a}$ & $103_{a b}^{a b}$ & $99_{b}^{a b}$ & $86_{c}^{b c}$ & $99_{b c}$ & 6.92 \\
\hline T8 & $107_{a}^{a}$ & $105^{a}$ & $101_{a^{a}}^{a}$ & $89_{b}^{b}$ & $101_{b}$ & 6.92 \\
\hline Mean & $107^{a}$ & $100^{b}$ & $94^{c}$ & $87^{d}$ & 97 & 1.65 \\
\hline LSD (0.05) & 5.15 & 5.24 & 4.75 & 5.72 & 2.48 & \\
\hline
\end{tabular}

All these results unrevealed the best performance of Eichhorniacrassipes and Bacillus cereus combination with maximum reduction in the value of BOD $(21.29 \%)$ of bleaching solution (figure $4, e)$. The high performance of this partnership regarding the reduction of BOD value could be due to the desirable rate of oxygen transfer through the roots of plants and high accumulation of microbes in rhizo/endo sphere of plants that resulted in degradation of organic pollutants.

\section{Effect of various treatments and hydraulic} retention time on COD value of bleaching solution

The results in table 8 pointed out significant $(\alpha=0.05)$ effects of all selected treatments on the COD value of the bleaching solution. The highest COD value along column (187 mg/L) was noted for control treatment C, while the lowest value $(170 \mathrm{mg} / \mathrm{L})$ was found for treatment T2. Similarly along row the highest value of
COD was noted for TM1 (187 mg/L) and lowest one was observed for TM4 (167 mg/L).

The effect of time on COD value was analyzed by applying regression analysis. The results represented in ANOVA, table 3, and the developed regression model described significant $(\alpha=0.05)$ inverse effects of time on COD value of the solution at the rate of 0.29 . The best representation of data ensured by high degree of certainty $\left(r^{2}=0.58\right)$, observed by the predicted equation (6)

$$
\mathrm{COD}=187.10-0.29 \times \mathrm{TM}
$$

These results disclosed the supremacy of Bacillus cereus augmented Eichhorniacrassipes based FTW system to have maximum reduction $(15.87 \%)$ in COD (figure 4,f) when compared with control treatment reactor. $C O D$ is an important pollutant indicating parameters and it reflects the amount of oxidizable contaminants present in wastewater. The reduction in COD is attached with the decomposition of these oxidizable pollutants due to the addition of oxygen by

EFFECT OF VARIOUS TREATMENTS (T) AND TIME (TM) ON COD VALUE OF BLEACHING SOLUTION

\begin{tabular}{|c|c|c|c|c|c|c|}
\hline \multirow{2}{*}{ Treatment } & \multicolumn{4}{|c|}{ COD } & \multirow{2}{*}{ Mean } & \multirow{2}{*}{$\operatorname{LSD}(0.05)$} \\
\hline & TM1 & TM2 & TM3 & TM4 & & \\
\hline C & $189_{a}^{a}$ & $187_{a}^{a}$ & $186_{a}^{a}$ & $186^{a}$ & $187_{\mathrm{a}}$ & 4.80 \\
\hline T1 & $18 \mathrm{a}^{\mathrm{a}}$ & $172_{b}{ }^{d}$ & $165_{c}{ }^{\text {ef }}$ & $160_{C}^{\text {de }}$ & $170_{\mathrm{e}}$ & 5.41 \\
\hline T2 & $187_{a}^{a}$ & $173_{b}^{c d}$ & $162_{c}^{f}$ & $159^{e}{ }^{e}$ & $170_{\mathrm{e}}$ & 6.59 \\
\hline T3 & $188_{a}^{a}$ & $179_{b}^{b c}$ & $167_{C}^{\text {de }}$ & $163_{\mathrm{C}}^{\text {cde }}$ & $174_{d}$ & 6.92 \\
\hline T4 & $188_{a}^{a}$ & $181_{b}^{a b}$ & $176_{b}^{b}$ & $167_{c}^{b c d}$ & $178_{c}$ & 6.92 \\
\hline T5 & $188_{a}^{a}$ & $178_{b}^{b c d}$ & $167_{\mathrm{c}}^{\mathrm{de}}$ & $163_{\mathrm{c}}^{\mathrm{bc}}$ & $174_{d}$ & 5.16 \\
\hline T6 & $18 a^{a}$ & $180_{b}^{b}$ & $171_{c}^{c d}$ & $165_{c}^{\text {bcde }}$ & $176_{c d}$ & 6.92 \\
\hline T7 & $188^{a}$ & $183_{a b}^{a b}$ & $175_{b c}^{b c}$ & $168_{C}^{b c}$ & $179_{c}$ & 10.18 \\
\hline T8 & $188^{a}$ & $187^{a}$ & $178_{\mathrm{b}}^{\mathrm{b}}$ & $171_{c}^{b}$ & $182_{b}$ & 6.32 \\
\hline Mean & $187^{a}$ & $180^{b}$ & $172^{c}$ & $167^{d}$ & 177 & 1.94 \\
\hline LSD (0.05) & 5.21 & 6.91 & 4.78 & 7.30 & 2.92 & \\
\hline
\end{tabular}


plants because of their photosynthetic activity as previously accredited [29]. Moreover inoculation of bacteria in the system boosted up this oxidation process by adding up plant growth that resulted in increase of photosynthetic activity and increasing of oxygen rate in the solution as reported earlier [27].

\section{Comparison of results of treated solution with NEQS and ZDHC standards}

A comparison of physicochemical quality parameters of treated $\mathrm{H}_{2} \mathrm{O}_{2}$ enriched textile bleaching wastewater by applying plant-bacteria synergized FTWs technique was made with industrial and municipal wastewater quality standards set by NEQS (National Environmental Quality Standards of Pakistan) and ZDHC (Zero Discharge of Hazardous Chemicals). All the parameters were found within the set limit,

Table 9

COMPARISON OF RESULTS WITH NEQS AND ZDHC INDUSTRIAL AND MUNICIPAL WASTEWATER STANDARDS

\begin{tabular}{|c|c|c|c|c|}
\hline $\begin{array}{c}\text { Textile } \\
\text { effluent } \\
\text { properties }\end{array}$ & For T2 and TM4 & Units & NEQS & ZDHC \\
\cline { 2 - 4 } & Bleaching solution & & & \\
\hline $\mathrm{pH}$ & $9.02 \pm 0.023$ & - & $6-10$ & $6-9$ \\
\hline $\mathrm{EC}$ & $3.23 \pm 0.017$ & $\mathrm{dS} / \mathrm{m}$ & - & - \\
\hline $\mathrm{TDS}$ & $1656 \pm 3.468$ & $\mathrm{mg} / \mathrm{L}$ & 3500 & - \\
\hline $\mathrm{TSS}$ & $77 \pm 2.312$ & $\mathrm{mg} / \mathrm{L}$ & 150 & $30-150$ \\
\hline $\mathrm{BOD}$ & $82 \pm 1.156$ & $\mathrm{mg} / \mathrm{L}$ & 80 & $30-150$ \\
\hline $\mathrm{COD}$ & $159 \pm 2.890$ & $\mathrm{mg} / \mathrm{L}$ & 150 & $40-400$ \\
\hline
\end{tabular}

The values in \pm are the standard errors. table 9, demonstrating the considerable efficacy of this technology to clean textile effluents.

\section{CONCLUSIONS}

The present study successfully investigates the efficacy of floating aquatic plants and their growth promoting and pollutant degrading bacteria in combined form by applying FTWs phytoremediation technique to degrade $\mathrm{H}_{2} \mathrm{O}_{2}$ enriched bleaching solution of textile industry. This technique marked itself a plausible approach to remediate textile bleaching effluents by making comprehensive reduction in major physicochemical parameters of effluent. After 72 hours retention time the combination of Eichhorniacraccipes and Bacillus cereus made extensive reduction in $\mathrm{pH}$ (8.80\%), EC (40.63\%), TDS (41.07\%), TSS (45.39\%), BOD (21.29\%) and COD (15.87\%) values of bleaching solution and consequently, bring them within the limits set by NEQS and ZDHC industrial wastewater standards. This embossed the efficacy of FTWs amplified with pollutant degrading and plant growth promoting bacteria to degrade textile bleaching effluents. Moreover, use of floating aquatic plants made FTWs technique more economical by the involvement of less infrastructure. It demonstrated the suitability of this technique to be applied directly on existing wastewater ponds, lakes, and drains or even in the running wastewater treatment plants in textile industry. Hence this technique can be a chemical free, less expensive, aesthetically pleasant and sustainable substitute to the existing expensive and complex wastewater techniques for textile effluents.

\section{REFERENCES}

[1] Kim, J.O., Traore, M.K., Worfield, C., The textile and apparel industry in developing countries, In: Textile Progress, 2006, 38,1-64

[2] Zahrim, A.Y., Hilal, N., Treatment of highly concentrated dye solution bycoagulation/flocculationes and filtration and nanofiltration, In: Water Resources and Industry, 2013, 3, 23-34

[3] Kadam, K.S., Watharkar, D.A., Chandanshive, V.V., Khandare, V. R., Jeon, B.H., Jadhav, J.P., Govindwar, S.P., Co-planted floating phyto-bed along with microbial fuel cell for enhanced textile effluent treatment, In: Journal of Cleaner Production, 2018, 203, 788-798

[4] Kurade, M.B., Waghmode, T.R., Khandare, R.V., Jeon, B.H., Govindwar, S.P., Biodegradation and detoxification of textile dye Disperse Red 54 by Brevibacilluslaterosporus and determination of its metabolic fate, In: Journal of Bioscience and Bioengineering, 2016, 121, 442-449

[5] Moga, I.C., Matache, M.G., Covaliu, I.C., Advanced wastewater treatment stage for textile industry, In: Industria Textila, 2018, 69, 6, 478-482, https://doi.org/10.35530/IT.069.06.1501

[6] Tzanov, T., Calafell, M., Guebitz, G.M., Cavaco-Paulo, A., Biopreparation of cotton fabrics, In: Enzyme Microbial Technology, 2001, 29, 357-362

[7] Varadarajan, G., Venkatachalam, P., Sustainable textile dyeing processes, In: Environmental Chemistry Letters, 2016, 14, 113-122

[8] Vineta, S., Silvana, Z., Sanja, R., Golomeova, S., Methods for wastewaters treatment in textile industry, In: International Scientific Conference "UNITECH 2014" - Gabrovo, 21-22 November

[9] Moga, I.C., Ardelean, I., Petrescu, G., Craciun, N., Popa, R., The potential of biofilms from moving bed bioreactors to increase the efficiency of textile industry wastewater treatment, In: Industria Textila, 2018, 69, 5, 412-418, https://doi.org/10.35530//IT.069.05.1500

[10] Rehman, K., Imran, A., Amin, I., Afzal, M., Inoculation with bacteria in floating treatment wetlands positively modulates the phytoremediation of oil field wastewater, In: Journal of Hazardous Material, 2018, 349, 242-251 
[11] Anuprita, D.W., Khandare, R.V., Waghmare, P.R., Jagadale, A.D., Govindwar, S.P., Jadhay, J.P., Treatment of textile effluent in a developed phytoreactor with immobilized bacterial augmentation and subsequent toxicity studies on Etheostomaolmstedi fish, In: Journal of Hazardous Material, 2015, 283, 698-704

[12] Arshad, A., Ali, S., Khan, S.N., Riaz, M., Arshad, S., Arslan, Ch, Noor, S., Waqas, M.M., Design of floating wetland for treatment of municipal wastewater and environmental assessment using emergy technique, In: Proceedings of the International Academy of Ecology and Environmental Sciences, 2017, 7, 3, 78-89

[13] Todd, J., Brown, E.J., Wells, E., Ecological design applied, In: Ecological Engineering, 20, 421-440

[14] Headley, T., Tanner, C.C., Council, A.R., Application of Floating Wetlands for Enhanced Stormwater Treatment: $A$ Review for Auckland Regional Council, In: Auckland Regional Council Technical publication TP324, Hamilton, 2008, 93, available at www.arc.govt.nz/plans/technical-publications/technical-publications-301-350.cfm

[15] Faulwetter, J., Burr, M., Cunningham, A., Stewart, F., Camper, A. and Stein, O., Floating treatment wetlands for domestic wastewater treatment, In: Water Science and Technology, 2011, 64, 2089-2095

[16] Li, H., Hao, H.L., Yang, X.E., Xiang, L.C., Zhao, F.L., Jiang, H., He, Z.L., Purification of refinery wastewater by different perennial grasses growing in a floating bed, In: Journal of Plant Nutrition, 2012, 35, 93-110

[17] Smith, M., Kalin, M., Floating Wetland Vegetation Covers for Suspended Solids Removal, In: Quebec 2000 Conference Proceedings. Treatment Wetlands for Water Quality Improvement, 2000

[18] Hussain, Z., Arslan, M., Malik, M.H., Mohsin, M., Iqbal, S., Afzal, M., Treatment of the textile industry effluent in a pilot-scale vertical flow constructed wetland system augmented with bacterial endophytes, In: Science of Total Environment, 2018, 645, 966-973

[19] Rafique, H.M., Bioremediation of petroleum hydrocarbon contaminated soil in association with plant (dissertation), 2015, Institute of Soil and Environmental Sciences, University of Agriculture Faisalabad Pakistan

[20] Hanson, K.G., Desai, J.D., Desai, A.J.,A rapid and simple screening technique for potential crude oil degrading microorganisms, In: Biotechnology Techniques, 1993, 7, 10, 745-748

[21] Jacobson, C. B., Pasternak, J. J., Glick, B.R., Partial purification and characterization of 1-aminocyclopropane-1carboxylate deaminase from the plant growth promoting rhizobacterium Pseudomonas putida GR12-2, In: Candian Journal of Microbiology, 1994, 40, 12, 1019-1025

[22] ljaz, A., Shabir, G., Khan, Q.M., Afzal, M., Enhanced remediation of sewage effluent by endophyte-assisted floating treatment wetlands, In: Ecological Engineering, 2015, 84, 58-66

[23] Nair, S.S., Swarnalatha, D.K., Biodegradation of laundry wastewater, In: International Journal of Engineering and Technology, 2015, 2, 789-793

[24] APHA. Standard Methods for the Examination of Water and Wastewater, In: 20th edition, 2005, American Public Health Association, Washington, DC

[25] Clark, V., SAS/STAT 9.1, In: User's Guide, 2004, North Carolina, SAS institute Inc. Cary. NC. USA

[26] Chang, Y., Cui, H., Huang, M., He, Y., Artificial floating islands for water quality improvement, In: Environmental Reviewes, 2017, 25, 350-357

[27] Tara, N., Iqbal, M., Khan, Q.M., Afzal, M., Bioaugmentation of floating treatment wetlands for the remediation of textile effluent. In: Water and Environmental Journal, 2019, 33, 1, 124-134

[28] Seenivasan, R.,Prasath, V., Mohanraj, R., Restoration of sodic soils involving chemical and biological amendments and phytoremediation by Eucalyptus camaldulensis in a semiarid region, In: Environmental Geochemistry and Health, 2015, 37, 575-586

[29] Abed, S.N., Almuktar, S.A., Scholz, M., Remediation of synthetic grey water in mesocosm - Scale floating treatment wetlands, In: Ecological Engineering, 2017, 102, 303-319

\section{Authors:}

MUHAMMAD TUSIEF QAMAR ${ }^{1,2}$, HUSSAN MALIK MUMTAZ², MUHAMMAD MOHSIN³, HAFIZ NAEEM ASGHAR ${ }^{4}$, MUHAMMAD IQBAL ${ }^{5}$, MAHMOOD NASIR ${ }^{1}$

${ }^{1}$ Department of Fibre and Textile Technology, University of Agriculture, Faisalabad, Pakistan

${ }^{2}$ School of Textile and Design, University of Management and Technology Lahore, Pakistan

${ }^{3}$ Department of Textile Engineering, University of Engineering and Technology Lahore, Faisalabad campus, Pakistan ${ }^{4}$ Institute of Soil and Environmental Sciences, University of Agriculture Faisalabad. Pakistan

${ }^{5}$ Department of Food Engineering, University of Agriculture, Faisalabad, Pakistan

\section{Corresponding author:}

MUHAMMAD MOHSIN

e-mail: mohsinmalikntu@yahoo.com 


\title{
Investigating the effect of self-cleaning treatment on the air permeability, stain removal and water repellency properties of functionalized double jacquard woven upholstery fabrics
}

\author{
DOI: $10.35530 / I T .070 .06 .1483$
}

\section{ABSTRACT - REZUMAT}

Investigating the effect of self-cleaning treatment on the air permeability, stain removal and water repellency properties of functionalized double jacquard woven upholstery fabrics

Self-cleaning is the important and required function for the upholstery fabrics. At this research, which was not studied in the references, nano $\mathrm{TiO}_{2}$ coating was appliqued on 18 double faced woven fabrics produced with jacquard weaving technique with three different weft density, two different raw materials of warp yarns that are polyester and rayon, three different face weave pattern under the same conditions by using sol-gel method. All fabrics were stained with the same amount of coffee. Self-cleaning efficiency of the applied fabrics were tested at spectrophotometer by using K/S (Colour/Strength) values after waiting 6, 12 and 24 hours under artificial sunlight and stain removal ratios were calculated. The effects of the fibre type, weft setting and weave pattern on the air permeability of upholstery fabrics were investigated by variance analysis by means of Minitab 17.0. $\mathrm{TiO}_{2}$ application caused air permeability reduction of $18-40 \%$ in polyester warp fabrics and $30-47 \%$ in rayon warp fabrics. It was seen that self-cleaning property can be got at double faced polyester/cotton and rayon/cotton fabrics by using nano $\mathrm{TiO}_{2}$. After 24 hours sunlight exposure, the average stain removal rates were found as $74.8 \%$ for polyester warp fabrics and $66.7 \%$ for rayon warp fabrics. Also, it has been observed that $\mathrm{TiO}_{2}$ application imparts hydrophobic properties to all rayon and polyester warp fabrics.

Keywords: double woven fabrics, nanoTiO ${ }_{2}$, self-cleaning, sol-gel method, fabric construction, air permeability, stain removal ratio, contact angle

Investigarea influenței tratamentului de autocurățare asupra proprietăților de permeabilitate la aer, îndepărtarea petelor și impermeabilitate la apă ale țesăturilor jacard duble pentru tapițerie funcționalizate

Autocurățarea este o funcție importantă și necesară țesăturilor pentru tapițerie. În cadrul acestei cercetări, un nanostrat de $\mathrm{TiO}_{2}$ a fost aplicat, în aceleași condiții, pe 18 țesături cu două fețe realizate prin tehnica de țesere cu mecanism jacard, cu trei desimi diferite ale bătăturii, două materii prime diferite pentru firele de urzeală, și anume poliester și viscoză, trei legături diferite pe fața țesăturii, folosind metoda sol-gel. Toate țesăturile au fost pătate cu aceeași cantitate de cafea. Eficiența de autocurățare a țesăturilor tratate a fost testată la spectrofotometru, prin utilizarea valorilor K/S (Culoare/Rezistență), după expunere timp de 6, 12 și 24 de ore, sub lumină artificială și calculul raportului de îndepărtare a petelor. Au fost analizate influențele tipului de fibră, ale desimii în bătătură și ale legăturii asupra permeabilității la aer a țesăturilor pentru tapițerie prin analiza varianței cu Minitab 17.0. Aplicarea de TiO ${ }_{2}$ a determinat reducerea permeabilității la aer cu 18-40\% pentru țesăturile cu urzeală din poliester și cu 30-47\% pentru țesăturile cu urzeală din viscoză. S-a observat că proprietatea de autocurățare poate fi obținută la țesăturile cu două fețe din poliester/bumbac și din viscoză/bumbac cu legături identice, folosind nano $\mathrm{TiO}_{2}$. După 24 de ore de expunere la soare, s-a constatat că raporturile medii de îndepărtare a petelor au fost de $74,8 \%$ pentru țesăturile cu urzeală din poliester și

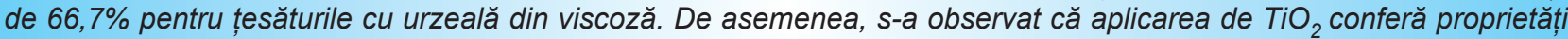
hidrofobe tuturor țesăturilor cu urzeală din viscoză și din poliester.

Cuvinte-cheie: țesături duble, nano $\mathrm{TiO}^{2}$, autocurățare, metoda sol-gel, structura țesăturii, permeabilitatea la aer, raport de îndepărtare a petelor, unghiul de contact

\section{INTRODUCTION}

Researches and applications of eco-friendly functions as self-cleaning property has been rising recently by increasing of awareness to the environment. The usage of these materials is in electronic, automotive, glass, dye, construction, textile industry as well as in various industrial areas like filters, packaging, metal anticorrosion, etc.

The semiconductor photo catalyst technology is the most efficient method which is favoured at decreasing of the nature pollution. At this technology, which can be activated by the help of sunlight, $\mathrm{TiO}_{2}, \mathrm{ZnO}$, $\mathrm{Fe}_{2} \mathrm{O}_{3}, \mathrm{CdS}, \mathrm{WO}_{3}, \mathrm{SnO}_{2}$ and $\mathrm{ZnS}$ can be used as photo catalysts. The semiconductors can mineralize the adsorbed biodegradable organic compounds and convert to $\mathrm{CO}_{2}$ and $\mathrm{H}_{2} \mathrm{O}$ by using sunlight [1].

The most common photo catalyst in textile is $\mathrm{TiO}_{2}$. It gets ahead because of many advantages like (1) its low toxicity, (2) applicability at ambient temperature and pressure, (3) mineralization ability of organic 
compounds without bringing on a secondary pollution, (4) low operation cost, (5) ability to destroy various pollutant, (6) activation capability under indoor or outdoor light [1].

Self-cleaning surfaces can be appliqued by several methods like electrospinning, etching, moulding, etc. [2]. Besides, by coating method (dip-coating, spincoating, spray-coating), it can be appliqued to all surfaces in a cheaper and faster way. Another coating method is sol-gel which has wide usage at transparent coating. By using this method, chemical and physical properties of chemical compounds can be adapted according to intended hydrophobicity, stability, flexibility and porosity [3].

Qui et al. [4], made experiments about an atase $\mathrm{TiO}_{2}$ application on cotton fabric by sol-gel process. At their study, transparent thin film was obtained on fibre surface with dip-pad-dry-cure process. It is seen that rigidity was increased by $13 \%$ and the air permeability was reduced by $0.76 \%$ after $\mathrm{TiO}_{2}$ treatment. Also it was tested degradation of coffee, red wine and curry stains on treated fabrics.

Factors like raw material, yarn properties, fabric type, knitting structure and fabric thickness effect the air permeability of fabrics as well as determine their physical, mechanic, sensory properties [5].

Gupta et al. [6] applied Nano $\mathrm{TiO}_{2}$ on the cotton fabric (plain weave; $113 \mathrm{~g} / \mathrm{m}^{-2}$; and EPI×PPI, $110 \times 82$ ) by sol-gel method without using any cross-linkers or adhesives. It was seen that cotton fabrics after $1 \mathrm{wt} \%$ $\mathrm{TiO}_{2}$ application had showed considerable self-cleaning activity for coffee stain when exposed to light for 12-48 hours. They had seen fast cleaning in the first 12 hours and stabilization after 48 hours. The decrease in the K/S value on the cotton fabric treated with the water-treated Nano-solution of $\mathrm{TiO}_{2}$ was $64.1 \%$ after 12 hours, $73.0 \%$ after 24 hours, and $76.5 \%$ after 48 hours.

Shahba et al. [7] investigated the effects of weaving construction of PES fabrics and its blend with cotton yarn on the self-cleaning efficacy after treatment with $\mathrm{TiO}_{2}$ nanoparticles. Three different blending ratio fabrics were formed by using two types of yarn material. Three kind of weaving construction and picks number were used for each blending ratio. It was seen that, the highest degree of self-cleaning properties was observed with satin-4 weaving construction, whereas the least degree of self-cleaning was seen at plain $1 / 1$ weaving construction. In addition, intermediate values of self-cleaning was observed at twill 4/4 weaving construction. It has been observed that in the same weaving construction, when the number of peaks was raised from 24 to 36 pick $/ \mathrm{cm}$, the selfcleaning properties of the fabrics showed a decrease in the degree of self-cleaning. It was also noted that $100 \%$ PES fabrics treated with $\mathrm{TiO}_{2}$ nanoparticles have the highest self-cleaning properties compared to the PES/cotton blend fabrics at the same picks number and weaving construction.

Ignat et al. [8] used synthesized $\mathrm{TiO}_{2}$ nanoparticles doped with different elements which have shown an improvement of the photocatalytic decomposition of organic pollutant models such as Orange II, Methylene Blue or ball pen ink in solution or on leather surface exposed to UV and/or Vis radiations. The use of doped $\mathrm{TiO}_{2}$ nanoparticles on leather surface showed soil repellency through contact angle increased values and self-cleaning properties under UV-Vis radiation exposure.

Zhang, Cai and Wang [9] introduced a photocatalytic material (the nano-sized titanium dioxide) into poly (lactic acid) (PLA) to produce films with self-cleaning function. Prototypes containing 0, 5, 10, 15 and 20 $w t \%$ nano filler were prepared and then etched with proteinase $\mathrm{K}$ to expose the nano particles on the surface. The self-cleaning function was assessed by the discoloration of methylene blue (MB) in aqueous condition via a UV-vis spectrophotometer. The samples containing $15 \mathrm{wt} \%$ nano filler could totally degrade the methylene blue after $24 \mathrm{~h}$ UV irradiation.

Although there are many studies on the application of $\mathrm{TiO}_{2}$ on fabric, a similar study comparing fabric construction on the basis of double weaving has not been encountered. At this study, $\mathrm{TiO}_{2}$ had been appliqued on polyester/cotton, rayon/cotton fabrics which had various weft density and face weave pattern by solgel method. The changes on air permeability and self-cleaning properties of fabrics according to their raw material, weft density and face weave pattern were investigated.

\section{EXPERIMENTAL}

\section{Materials}

Acetic Acid (Glacial 100\%-EMSURE, Amerikan Chemical Society, International Organization for Standardization, Reagents the European Pharmacopoeia-anhydrous for analysis) and Nitric Acid 65\% (extra pure) were purchased from Merck. Titanium (IV) Isopropoxide (\%97) was supplied from Sigma Aldrich.

In this research 18 kinds of self-stitched double woven fabric samples, whose face weave pattern have been 5 s sateen, 10 s sateen, 20 s sateen and back weave has been $5 \mathrm{~s}$ sateen, were been produced in Mega Textile Industry and Trade Inc. by Dornier machine with rapier picking mechanism. 150 denier of filament polyester yarn with twist of $160 \mathrm{tpm}$ in S direction and of filament rayon yarn with twist of $500 \mathrm{tpm}$ in S direction were used as warp yarns. In addition to this, Ne 30/2 cotton yarn with twist of $710 \mathrm{tpm}$ in $\mathrm{S}$ direction was planned as weft yarns. Warp settings of fabric samples were $66 \mathrm{~cm}^{-1}$, weft settings of fabric samples were $32 \mathrm{~cm}^{-1}, 35 \mathrm{~cm}^{-1}$ and $38 \mathrm{~cm}^{-1}$ [10]. Fabric samples were coded according to weft density, raw material of warp yarns and of weft yarns, face weave pattern as in table 1. The numbers in fabric codes represent weft densities, raw materials of warp yarns and of weft yarns, face weave patterns respectively. These are square unit weaves, so the number of each warp and weft yarn interlacing is equal to each other, namely the average yarn interlacing is equal to number of yarn interlacing. 
The fabric property, the weave interlacing coefficient, defined by Galcerán [11] has been calculated by:

$$
K L=\frac{i}{w_{1} \times w_{2}}
$$

where $i$ is the number of interlacing points in weave repeat, $w_{1}$ - the number of ends in weave repeat, $w_{2}$ - the number of picks in weave repeat.

And also the average float length of warp yarn is equal to the average float length of weft yarn. The average float length $F$ has been calculated according to Ashenhurst [12] by equation (2):

$$
F_{1 / 2}=\frac{R_{2 / 1}}{t_{1 / 2}}
$$

where: $R_{2 / 1}$ is the weft (2) or warp (1) repeat; $t_{2 / 1}$ - the number of warp of weft intersections in the weave repeat. Type of weave pattern can be seen in figure 1.

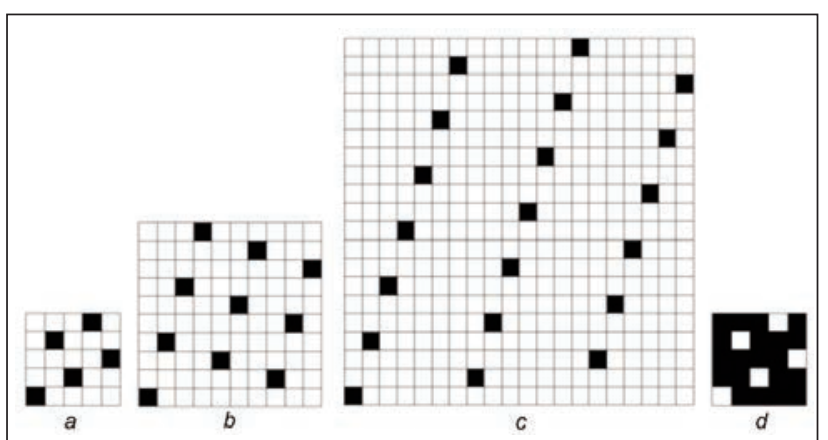

Fig. 1. Weave patterns: $a-5$ s sateen; $b-10$ s sateen; $c-20$ s sateen; $d-5$ s satin
The technical properties of sample fabrics are introduced in table 1.

\section{Method}

\section{Preparing of Sol-Gel}

Chemical applied on fabrics was prepared by sol-gel method at laboratories of YÜNSA Worsted and Woollen Production and Trading Co. Softened water inside the beaker was put on heater. While it was being mixed violently with mechanic stirrer at 1200 rpm, Acetic Acid, Nitric Acid and Titanium (IV) Isopropoxide (TTIP) were added into the solution. Heater was set to $80^{\circ} \mathrm{C}$. It is being gone on stirring at this temperature until homogeny, transparent view occurs in the solution. A few hours later, $\mathrm{TiO}_{2}$ nanoparticles (NP) were obtained [13].

\section{Application Method}

The application of the prepared solution on fabrics is performed at mini stenter which was placed in finishing department of YÜNSA Worsted \& Woollen Production and Trading Co. Washed and dried fabrics were passed into the solution diluted in the ratio of $1 / 2$. After squeezing at 7.5 bar pressurized cylinder, they were passed through drying and fix cabins at $180{ }^{\circ} \mathrm{C}$ with $1 \mathrm{~m} / \mathrm{min}$ velocity. The velocity of fans was set at 1800 cycle/min.

\section{Air Permeability Test Method}

The fabric samples were conditioned at standard atmosphere conditions $\left(20 \pm 2^{\circ} \mathrm{C}, \% 65 \pm 2\right.$ relative humanity) for 24 hours. Air permeability of fabrics

\begin{tabular}{|c|c|c|c|c|c|c|}
\hline Number & $\begin{array}{c}\text { Weft } \\
\text { density }\end{array}$ & $\begin{array}{l}\text { Raw material } \\
\text { of warp yarns }\end{array}$ & $\begin{array}{l}\text { Raw material } \\
\text { of weft yarns }\end{array}$ & $\begin{array}{l}\text { Face weave } \\
\text { pattern }\end{array}$ & $\begin{array}{l}\text { The weave } \\
\text { interlacing coefficient }\end{array}$ & $\begin{array}{l}\text { The average } \\
\text { float length }\end{array}$ \\
\hline 1 & 32 & Polyester & Cotton & 5s sateen & 0.4 & 2.5 \\
\hline 2 & 32 & Polyester & Cotton & 10s sateen & 0.2 & 5 \\
\hline 3 & 32 & Polyester & Cotton & 20s sateen & 0.1 & 10 \\
\hline 4 & 35 & Polyester & Cotton & 5 s sateen & 0.4 & 2.5 \\
\hline 5 & 35 & Polyester & Cotton & 10s sateen & 0.2 & 5 \\
\hline 6 & 35 & Polyester & Cotton & 20s sateen & 0.1 & 10 \\
\hline 7 & 38 & Polyester & Cotton & 5 s sateen & 0.4 & 2.5 \\
\hline 8 & 38 & Polyester & Cotton & 10s sateen & 0.2 & 5 \\
\hline 9 & 38 & Polyester & Cotton & 20s sateen & 0.1 & 10 \\
\hline 10 & 32 & Rayon & Cotton & 5s sateen & 0.4 & 2.5 \\
\hline 11 & 32 & Rayon & Cotton & 10 s sateen & 0.2 & 5 \\
\hline 12 & 32 & Rayon & Cotton & 20s sateen & 0.1 & 10 \\
\hline 13 & 35 & Rayon & Cotton & 5 s sateen & 0.4 & 2.5 \\
\hline 14 & 35 & Rayon & Cotton & 10s sateen & 0.2 & 5 \\
\hline 15 & 35 & Rayon & Cotton & 20s sateen & 0.1 & 10 \\
\hline 16 & 38 & Rayon & Cotton & 5s sateen & 0.4 & 2.5 \\
\hline 17 & 38 & Rayon & Cotton & 10s sateen & 0.2 & 5 \\
\hline 18 & 38 & Rayon & Cotton & 20s sateen & 0.1 & 10 \\
\hline
\end{tabular}

TECHNICAL PROPERTIES OF SAMPLE FABRICS 
was tested in reference to TS 391 EN ISO 9237 standard.

Textile material is put under the head of test device the way that it is not wrinkle. $5 \mathrm{~cm}^{2}$ experiment space is placed on the surface of circular fabric holder. The air vacuum system is run and the test is gone on until the pressure difference between two faces of the fabric reaches to $200 \mathrm{~Pa}$ by gradually increasing the air flow which is passed from inside of specific area of the sample. The air flow amount which is passed from inside of the fabric is recorded as $\mathrm{I} /\left(\mathrm{m}^{2} \cdot \mathrm{s}\right) .10$ tests were done by taking homogeny samples from side-middle-side areas of the fabrics.

\section{Self-CleaningFunctionality Test Method}

Treated fabrics were soiled with $0.4 \mathrm{ml}$ coffee. To evaluate the self-cleaning functionality of stained fabrics, they were left under the artificial sunlight irradiation (xenon arc lamp) for 6, 12, and 24 hours. K/S values of the stained fabrics were measured before and after exposing the sunlight by spectrophotometer.

The effectiveness of stain degradation was tested using Q-Sun light fastness measurement device. After some periods of time sunlight exposure, the changes on K/S values of stained fabrics were monitored by Data colour 600 dual-beam spectrophotometer.

\section{Statistical evaluation}

Obtained air permeability results were analysed statistically by the help of Minitab 17 program. It was verified that general linear model of before and after finishing had worked with $95 \%$ precision level. During variance analyses, it was realized that "*” marked $P$ values were statistically important for $95 \%$ precision level.

\section{RESULTS AND DISCUSSIONS}

The air permeability of untreated and treated fabrics was tested. The decrease of the air permeability values of all fabrics after self-cleaning application can be seen in figure 2 . While decreasing ratio at polyester warp fabrics were seen between 18 and $40 \%$, as for $30-47 \%$ at rayon warp fabrics.

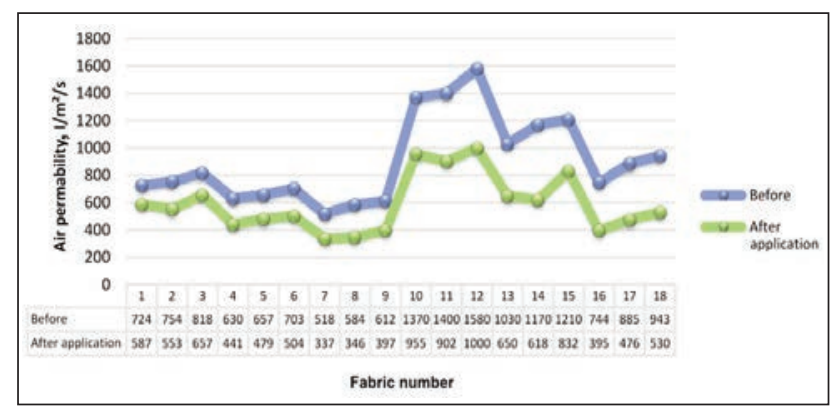

Fig. 2. The average air permeability of the fabrics as before and after application

Variance analyses of before and after application on fabrics are given in table 2 .

Interaction comparison graphics of the fabrics before self-cleaning application are presented in figure 3, a. As seen in figure $3, a$, the air permeability values

\begin{tabular}{|l|c|c|c|c|}
\hline \multicolumn{5}{|c|}{ VARIANCE ANALYSES } \\
\hline \multicolumn{1}{|c|}{ Source } & \multicolumn{1}{|c|}{ Before finishing } & \multicolumn{2}{c|}{ After finishing } \\
\cline { 2 - 5 } & $\mathbf{F}$ & $\mathbf{P}$ & $\mathbf{F}$ & $\mathbf{P}$ \\
\hline Weft density & 383.450 & $0.000^{*}$ & 103.9 & $0.000^{*}$ \\
\hline $\begin{array}{l}\text { Raw material } \\
\text { of warp yarns }\end{array}$ & 1720.880 & $0.000^{*}$ & 124.07 & $0.000^{*}$ \\
\hline $\begin{array}{l}\text { Face weave } \\
\text { pattern }\end{array}$ & 49.700 & $0.001^{*}$ & 8.89 & $0.034^{*}$ \\
\hline $\begin{array}{l}\text { Weft density } \\
\text { Raw Material } \\
\text { of warp yarns }\end{array}$ & 98.500 & $0.000^{*}$ & 12.02 & $0.020^{*}$ \\
\hline $\begin{array}{l}\text { Weft density* } \\
\text { Face weave } \\
\text { pattern }\end{array}$ & 2.040 & 0.254 & 0.74 & 0.609 \\
\hline $\begin{array}{l}\text { Raw Material of } \\
\text { warp yarns } \\
\text { weave pattern }\end{array}$ & 7.450 & $0.045^{*}$ & 0.93 & 0.466 \\
\hline
\end{tabular}

decreased by increasing weft density. When we compare polyester and rayon warp fabrics, it is seen that rayon warp fabrics which is produced from regenerated cellulose fibres as filament, softy and flexible structure, and has similar touch and brightness properties with silk had more air permeability than polyester which has synthetic structure. This is due to the fact that regenerated cellulous yarn, namely rayon, is more fibrous and porous than polyester yarn. Therefore, the porosity of the fabrics woven by rayon warps increase because of the air pressure during the air permeability test and these fabrics become more permeable.

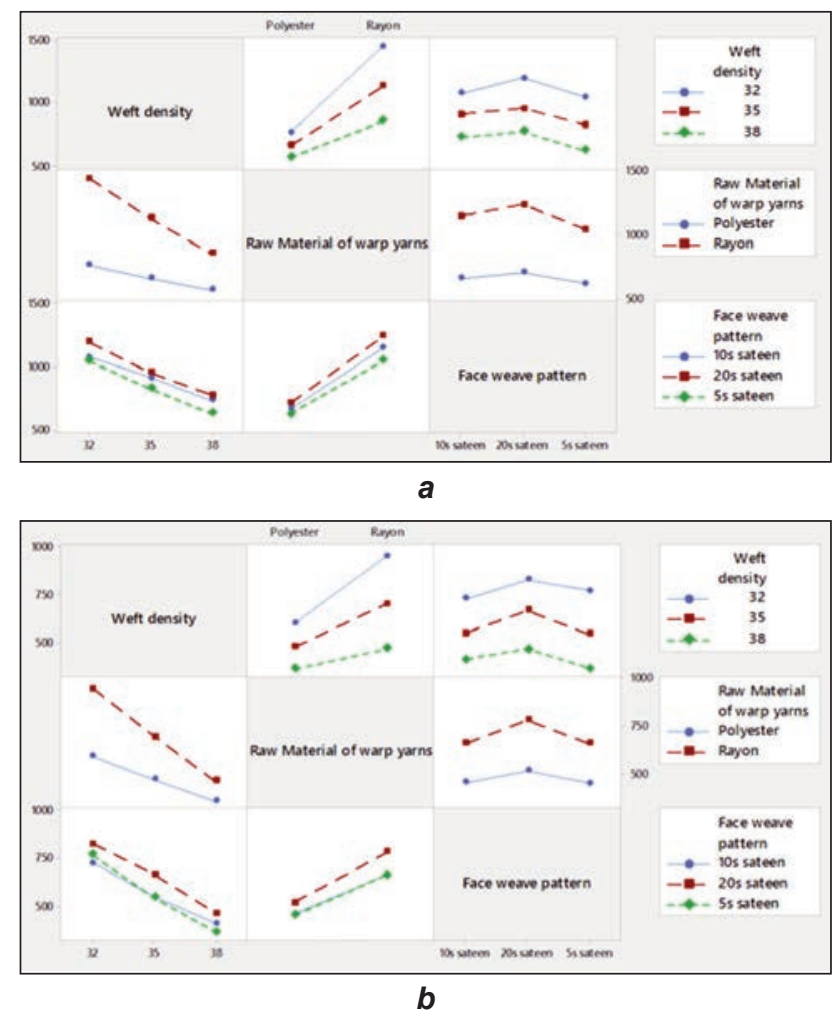

Fig. 3. Interaction plot of air permeability of fabrics: $a$ - before and $b$ - after finishing 
At Hristian's work [14], after testing the air permeability of the fabrics woven with Wool, Wool/Polyester, Wool/Polyester/Dorlastan and Polyester/Rayon yarns, they had seen that rayon content fabrics had more air permeability than others.

When the face weave sateen numbers are compared, a rise is obtained at air permeability by increasing the average float length and decreasing weave interlacing coefficient. As it was expected, it is monitored that the fabrics have more air permeability values by having more open area on surface.

It can be followed from figure $3, b$ that the air permeability of all fabrics goes down after self-cleaning application but the interactions between weft density, raw material and face weave sateen numbers look similar at before and after application.

After self-cleaning application, polyester warp specimens showed a reduction of $29.06 \%$ in air permeability averages, while Rayon warp specimens showed a reduction of $49.43 \%$. The reason is that there were more chemical attraction and adhesion at the cellulose-based regenerated fibre, Rayon, than polyester. Due to the high ratio of polyester crystalline region and polar structure, the moisture retention is low. Water molecules can only attach to the fibre surface in the form of a molecular film layer. It absorbs up to $0.4 \%$ moisture at room temperature and under standard conditions. Because of its structural condition, the rate of decrease in air permeability was observed less due to the less adherent coating.

Existence of self-cleaning functionality on the stained fabrics is tested before and after 6, 12 and 24 hour's artificial sunlight exposure. As seen in figure 4, K/S values of all stained fabrics at $400 \mathrm{~nm}$ are falling down as time passes by.

When we look at first states of fabrics called as unexposed, despite the same amount of coffee being spilled, after 4 hours minimum take-over is seen at fabric 4 which was woven with weft density of 35 , polyester warp yarns and 5 s sateen face weave pattern and fabric 18 which was woven with weft density of 38 , rayon warp yarns and 20 s sateen face weave pattern.

Among the fabrics exposed to the sunlight for 6 and 12 hours, the ones having the least stain are the fabrics 12 and 3 respectively. After 24 hours sunlight exposure, minimum stain mark is seen at fabric 3 which was woven with weft density of 35 , polyester warp yarns and 20 s sateen face weave pattern. The

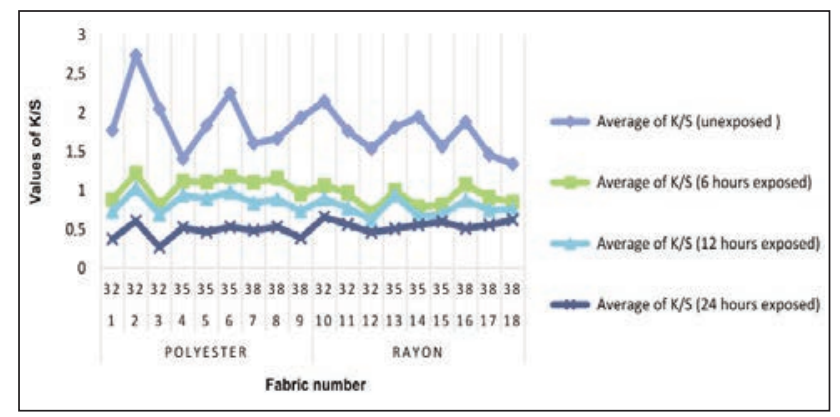

Fig. 4. K/S values of stained fabrics at $400 \mathrm{~nm}$ reason for not seeing any further decrease in the K/S values of the fabric numbered 12 after 24 hours is due to the natural brightness of rayon.

To check the self-cleaning ability according to fabric variety, stain removal percentage was calculated by using equation (3):
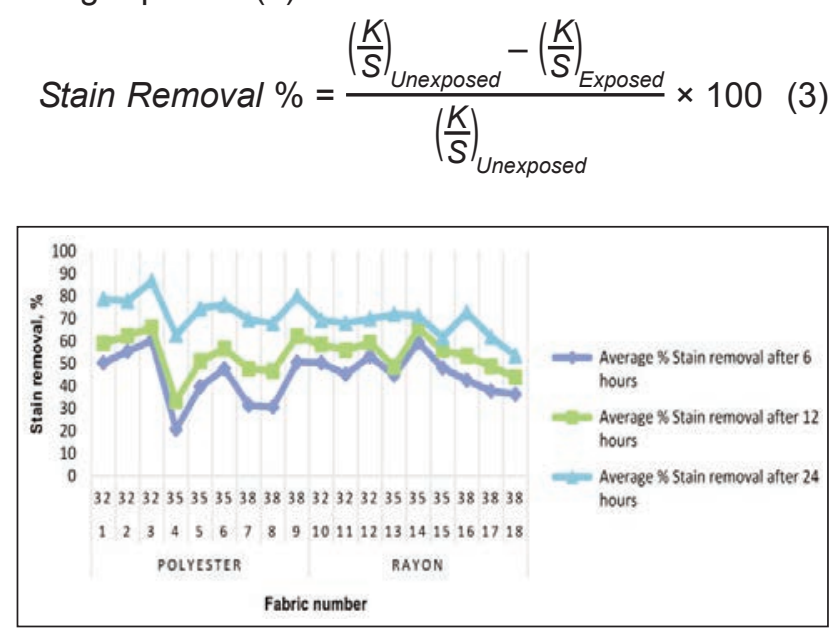

Fig. 5. Percentage change of stain removal due to fabric variety

As can be followed from figure 5 , stain removal ratios at polyester warp fabrics from 1 to 9 rise with increasing sateen number. We see the highest stain removal ratios at fabrics which were woven with weft density of 32 and also that polyester warp fabrics which were woven weft densities of 35 and 38 give similar results. When we look at rayon warp fabrics, it is seen the changes at sateen number did not affect the stain removal ratio forfabrics woven with weft density of 32. On the other hand, fabrics woven with weft densities of 35 and 38 , the stain removal falls down by rising sateen numbers. A slight decline is seen by increasing weft density at rayon warp fabrics but not like as being at polyester warp fabrics.

When we compare the stain removal ratios between polyester and cotton warp fabrics, the results show us the polyester warp fabrics are able to eliminate the stains more than the rayon warp fabrics at 32 weft density. On the other hand, the stain removal ratios of the rayon fabrics get close to the polyester fabrics results at 35 weft density. The results show that different removal ratios can be got for polyester and Rayon fabrics woven with weft density of 38 .

All fabrics were soiled with $0.4 \mathrm{ml}$ coffee. The initial and waited state $(6,12$ and 24 hours under artificial sunlight) of the fabric samples were presented in figure 6 and figure 7 respectively. The removal ratios were also promoted with the colour change visuals of stained fabrics as time progresses.

Besides of self-cleaning property, contact angles were tested to obtain water repellency effect of $\mathrm{TiO}_{2}$ between polyester and rayon warp fabrics. The results are given in figure 8 . Although rayon yarns have attraction to the water, rayon warp fabrics give similar contact angles with polyester warp fabrics after $\mathrm{TiO}_{2}$ application. Since all raw fabrics are 


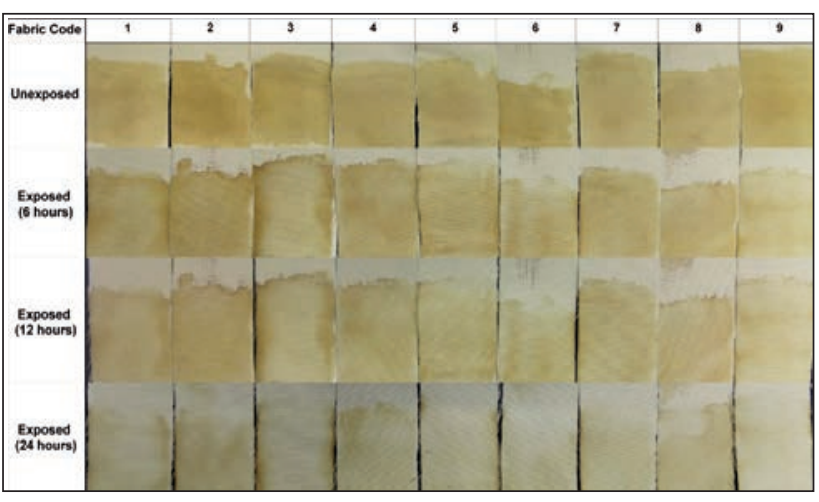

Fig. 6. Colour change of stained fabrics (1-9)

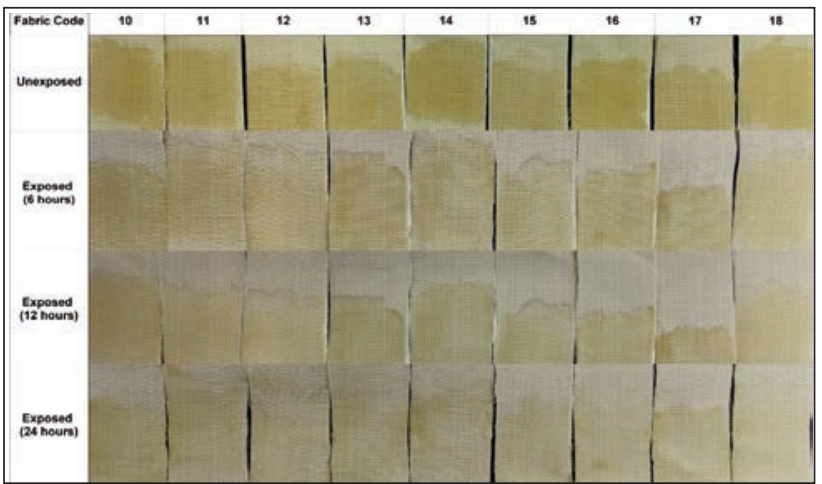

Fig. 7. Colour change of stained fabrics (10-18)

hydrophilic, all contact images are flat. All treated fabrics show hydrophobic property; even some of them are very close to being super hydrophobicity.

When contact angles are compared according to the raw materials warp yarn, the arithmetic average of the rayon warp fabrics was found to be lower 1 degree than that of polyester warp fabrics, but there was not found any statistical significance.

\section{CONCLUSION}

Air permeability and easy clean ability are the most desirable features in the upholstery fabrics. In this work, the double-faced upholstery fabrics are provided with self-cleaning properties without significantly reducing air permeability. After $\mathrm{TiO}_{2}$ application by sol-gel method, air permeability values of polyester and rayon warp fabrics decreased by $29.06 \%$ and $49.43 \%$, respectively. To test the self-cleaning feature, the fabrics stained with coffee were kept under artificial sunlight. The stain removal values $\%$ were calculated from the $\mathrm{K} / \mathrm{S}$ values measured in the spectrophotometer. Stain removal rates of stained polyester and rayon warp fabrics exposed to sunlight

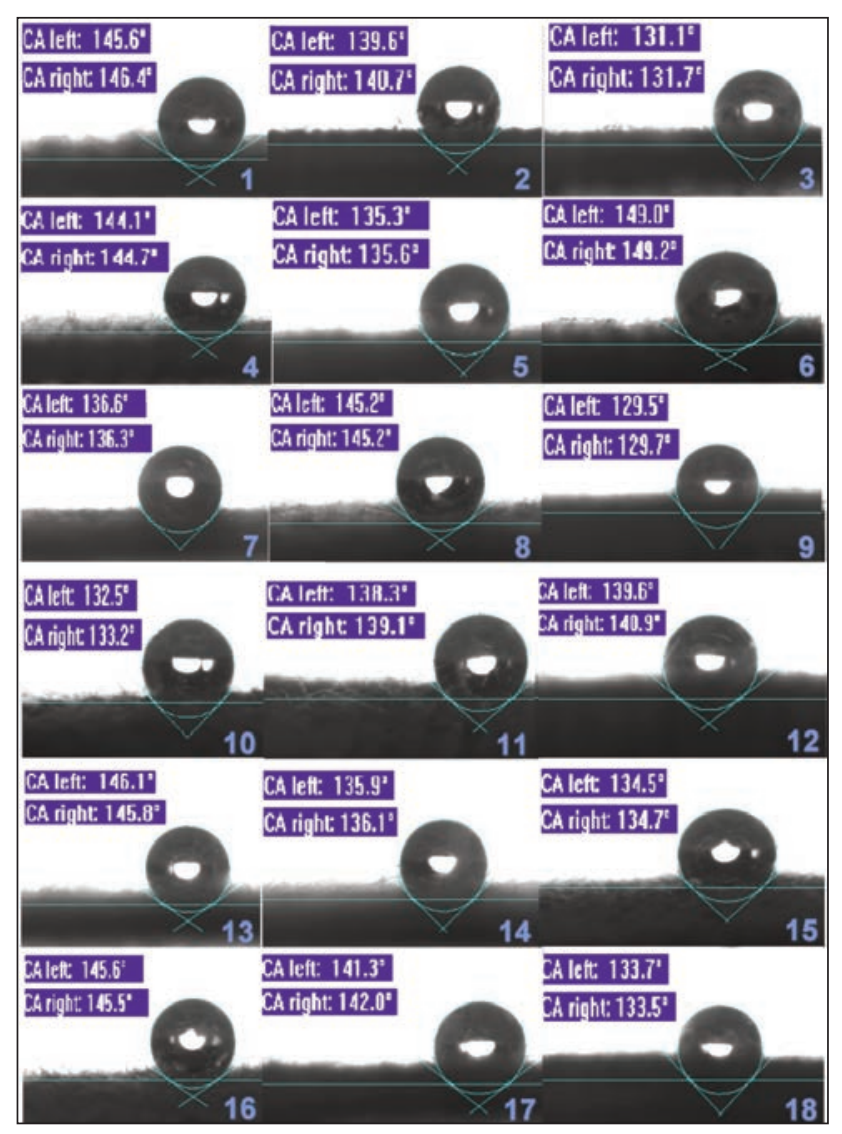

Fig. 8. Contact angle test results of $\mathrm{TiO}_{2}$ treated fabrics

were $42.9 \%$ and $46.4 \%$ after 6 hours, $53.9 \%$ and $54.4 \%$ after 12 hours, $74.9 \%$ and $66.7 \%$ after 24 hours, respectively. The K/S values of the rayon warp fabric do not fall more after a certain period of time, the reason is that the rayon has natural brightness. From the contact angle measurements, it was observed that $\mathrm{TiO}_{2}$ application caused hydrophobic effect on all fabrics which were hydrophilic before the application; even some fabrics have become super hydrophobic. Polyester warp fabric with 20 s sateen face weave pattern with 35 weft density and rayon warp fabric with $5 s$ sateen face weave pattern with 38 weft density were found the most suitable ones to be used as home textile upholstery fabric which is desired to be easily cleaned. As a continuation of the work, different warp and weft yarn raw materials, different face weave patterns can be tried or this work can also be done in single layer fabrics.

\section{ACKNOWLEDGEMENTS}

The author would like to thanks to workers of Yünsa Worsted \& Woollen Production and Training Co. for helps during experimental phase of this study.

\section{REFERENCES}

[1] Wang, J., Zhao, J., Sun, L., Wang, X., A Review on the Application of Photocatalytic Materials on Textiles, In: Textile Research Journal, 2015, 85, 10, 1104-1118

[2] Chen, J., Zhong, X., Lin, J., Wyman, I., Zhang, G., Yang, H., Wang, J., Wu, J., Wu, X., The Facile Preparation of Self-Cleaning Fabrics, In: Composites Science and Technology, 2016, 122, 1-9 
[3] Power, A.C., Barrett, A., Abubakar, J., Suarez, L.J., Ryan, L., Wencel, D., Sullivan, T., Regan, F., Versatile SelfCleaning Coating Production through Sol-Gel Chemistry, In: Advanced Engineering Materials, 2016, 18, 1, 76-82

[4] Qi, K., Wang, X., Xin, J.H., Photocatalytic self-cleaning textiles based on nanocrystalline titanium dioxide, In: Textile Research Journal, 2011, 81,1, 101-110

[5] Turan B veOkur A., Air Permeability in Fabrics, In: TMMOB Journal of Textile and Engineer, 2015, 72, 16-25

[6] Gupta, K.K., Jassal, M., Agrawal, A.K., Sol-gel derived titanium dioxide finishing of cotton fabric for self-cleaning, In: Indian Journal of Fibre \& Textile Research, 2008,33, 443-450

[7] Shahba, A.F., Bisi, M.E., Effect of weaving construction and blending ratio on self-cleaning properties of polyester and polyester/cotton blend fabrics treated with TiO2 nanoparticles, In: International Journal of Advance Research in Science and Engineering, 2015, 4, 6, 147-157

[8] Ignat, M., Petica, A., Gaidau, C., Dumitrescu, I., Surdu, L., Dinca, L., Ma, J.Z., Gao, J.J., Photocatlytic nanomaterials based on doped $\mathrm{TiO}_{2}$ for leather garments and upholstery with self-cleaning properties, In: Industria Textila, 2016, 67, 5, 308-313

[9] Zhang, C., Cai, X., Wang, F., Preparation and evaluation of the self-cleaning poly (lactic acid) (PLA) film blended with Titanium dioxide $\left(\mathrm{TiO}_{2}\right)$ nanoparticles, In: Industria Textila, 2016, 67, 2, 121-126

[10] Yavuzkasap D., A research on the mechanical properties of upholstery fabrics, MSc Thesis Dokuz Eylül University. The Graduate School of Natural and Applied Sciences, İzmir, Turkey, 2011

[11] Galceran, V., Weaving Technology, Technical University of Catalonia, Terrassa, (in Spanish), 1962

[12] Ashenhurt, T.R., A treatise on textile calculations and the structure of fabrics, Broadbent, Huddersfield, Yorkshire, 1884

[13] Palamutcu, S., Akman, O., Gulmez, S., Aydın, I., Selcuk, H. Functionalization of Wool Blend Fabrics Using TiO UTIB Turkish Textile and Clothing Sector VI. International R\&D Brokerage Event. Bursa, 3-4 April 2014

[14] Hritian, L., Researches Concerning The Air Permeability of Woven Fabrics Made from Combed Wool Yarns, In: Buletinul Institutului Politehnic din Iaşi, publicat de Universititatea Tehnica 'Georghe Asachi' din Iaşi, 2011, 57, 61, 2, 29-37

\section{Authors:}

\section{DUYGU YAVUZKASAP AYAKTA ${ }^{1}$, NAZLI ÇAĞLAR CINPERI ${ }^{1}$, HAKAN ÖZDEMIR ${ }^{2}$}

${ }^{1}$ Yünsa Worsted \&Woolen Production and Training Co, R\&D Center, 59500 Tekirdağ/Turkey

e-mail: dayakta@yunsa.com, textilengineer.duygu@gmail.com,ncinperi@yunsa.com, webpage: http://yunsa.com/en/

${ }^{2}$ Dokuz Eylül University, Department of Textile Engineering, $35390 \mathrm{Izmir} / T u r k e y$

e-mail: h.ozdemir@deu.edu.tr

Corresponding author:

DUYGU YAVUZKASAP AYAKTA

e-mail: dayakta@yunsa.com, textilengineer.duygu@gmail.com 


\section{A new method: the usage of natural zeolite as a killer chemical for hydrogen peroxide during the hydrogen peroxide bleaching}

DOI: 10.35530/IT.070.06.1523

CANDAN AKCA

\section{ABSTRACT - REZUMAT}

\section{A new method: the usage of natural zeolite as a killer chemical for hydrogen peroxide during the hydrogen peroxide bleaching}

In the study, the usage possibility of natural zeolite as hydrogen peroxide killer during the hydrogen peroxide bleaching was investigated. Natural zeolite from Gördes region with $30 \mu \mathrm{m}$ particle size was used during the hydrogen peroxide bleaching of the cotton fabric as a hydrogen peroxide killer agent. ICP-MS elemental analysis of the natural zeolite was performed. Hydrogen peroxide concentration of the bleaching liquor was performed by quantitative analysis. It was seen that natural zeolite is so efficient to decrease in hydrogen peroxide concentration in the bleaching bath. It is thought that natural zeolite can be an alternative to antiperoxide enzymes and the other hydrogen peroxide killers which are commonly used in the industry.

Keywords: natural zeolite, hydrogen peroxide, bleaching, antiperoxide enzyme, peroxide titration, ICP-MS

Metodă nouă: utilizarea zeolitul natural pentru eliminarea chimică a peroxidului de hidrogen în timpul albirii

În acest studiu s-a investigat posibilitatea utilizării zeolitului natural ca agent de eliminare a peroxidului de hidrogen în timpul albirii. Zeolitul natural din regiunea Gördes cu dimensiunea particulelor de $30 \mu \mathrm{m}$ a fost utilizat în timpul albirii cu peroxid de hidrogen a țesăturii de bumbac. A fost efectuată analiza ICP-MS a zeolitului natural. Concentrația de peroxid de hidrogen a flotei de albire a fost determinată prin analiza cantitativă. S-a observat că, zeolitul natural este foarte eficient pentru a scădea concentrația de peroxid de hidrogen în baia de albire. Se consideră că, zeolitul natural poate fi o alternativă la enzimele antiperoxid și la ceilalți agenți de eliminare a peroxidului de hidrogen, care sunt utilizate frecvent în industrie.

Cuvinte-cheie: zeolit natural, peroxid de hidrogen, albire, enzime antiperoxid, titrare cu peroxid de hidrogen, ICP-MS

\section{INTRODUCTION}

Hydrogen peroxide is commonly used in many practices such as bleaching, disinfection and oxidation. Hydrogen peroxide is an attractive oxidizing agent because its reaction products are water and oxygen. The most commonly used bleaching method in textile industry is hydrogen peroxide bleaching because it produces acceptable reaction products toxicologically and environmentally [1-3].

Even though numerous studies on the degradation of the hydrogen peroxide were done, the reaction still could not be figured out completely [4-5]. But the common opinion is that the ionic degradation products of the hydrogen peroxide have bleaching effect and radical degradation products cause damage. Dannacher and Schlenker suggested that the perhydroxyl radical ion has a bleaching effect. Hydrogen peroxide does not have bleaching effect in acidic environment, bleaching can be realized only by means of particular auxiliary products. Especially alkali environment is required for the conventional peroxide bleaching. When the alkali is added to the hydrogen peroxide solution, perhydroxyl anions occur and the bleaching happens. Sodium hydroxide activates hydrogen peroxide. Because $\mathrm{H}^{+}$ion which is needed for $\mathrm{HO}_{2} \cdot$ release neutralizes with the alkali. When activator and stabilizer are added to the environment in hydrogen peroxide, it is possible to realize the process at a lower temperature, at lower $\mathrm{pH}$, in a shorter period and with lower peroxide considerations and in more moderate conditions with more control and without damaging the fabric. Also, the risk of damage of the fabric is reduced by removing the hydrogen peroxide from the environment by means of various chemicals or antiperoxide enzymes quickly in the end of the process, and efficiency and quality of the next dying process is enhanced [5-8].

Zeolite is a mineral which is abundantly found in nature and of which handling is easier and cheaper compared to other minerals. Zeolite mineral is a remarkable mineral due to its high ion exchanging capacity, adsorption capacity and other features and its usage area gets larger every passing day. Today, its main usage areas are contamination control, energy production, agriculture and stock raising, mining and metallurgy, paper industry, health sector, detergent industry, besides, it is thought that its usage area will get larger as a results of the studies carried out in this respect [9].

Due to outstanding characteristics of zeolite which is abundantly found in our country, it is important to 
investigate the usage areas of the zeolite the field of textile finishing and improve the implementation opportunities, in terms of enabling the eco-friendly textile production and turning our rich zeolite reserve into added-value [9].

Finnegan et al. analyzed the degradation of hydrogen peroxide by adding zeolite and sodium citrate to the environment in the process of hydrogen peroxide bleaching in one of the study they performed in 1998. It was reported that the zeolite could not prevent the degradation of the hydrogen peroxide degradation in an alkali environment, besides it accelerated the degradation by interact with hydrogen peroxide. It was suggested that the manganese cations which are a transfer product between manganese ions of the sodium citrate and zeolite helped the movement of the manganese cations towards the zeolite structure. It was also stated that the change of the sodium citrate quantities in the environment changed the manganese -citrate complex quantities [10].

In this study, the effect of the peroxide on the hydrogen peroxide bleaching was examined.

\section{MATERIAL AND METHOD}

In this study, natural zeolite consisting 90\% clinoptilolite, originating from Gördes region, with $30 \mu \mathrm{m}$ particle size was used. Weighing $5 \mathrm{~g}, 139 \mathrm{~g} / \mathrm{m}^{2}$, $100 \%$ cotton raw jersey fabric was used in the process. The process was carried out by using the prescription written below and adopting the process conditions and process graphic (table 1). In this way, the peroxide killer effect of the zeolite was analyzed. The processes were carried out in Termal branded sample dyeing machine.
During the process, hydrogen peroxide quantity in the bath assessed iodometrically with 15 minuteintervals.

\section{Method}

In the stage I, $10 \mathrm{ml}$ bleach flotte whose concentration will be analyzed is acidified with $40 \mathrm{ml}, 10 \%$ sulfuric acid solution $\left(\mathrm{H}_{2} \mathrm{SO}_{4}\right)$ in an erlenmayer. After that, 2-drops of $10 \%$ potassium iodide $(\mathrm{KI})$ solution are added and kept in dark for 5 minutes after 2-3 pieces of ammonium molybdate $\left(\left(\mathrm{NH}_{4}\right)_{6} \mathrm{Mo}_{7} \mathrm{O}_{24}\right.$. $4 \mathrm{H}_{2} \mathrm{O}$ ) particle added. Meanwhile, $\mathrm{H}_{2} \mathrm{O}_{2}$ in the flotte oxidizes an equivalent quantity of iodide $\left(\mathrm{I}^{-}\right)$to molecular iodine $\left(\mathrm{I}_{2}\right)$. In the stage II, the solution remains colorless until the first thiosulphate drops to the bath even though starch is added. However, a dark blueblack color is seen as soon as the thiosulphate is dropped. Until the color is disappeared, $\mathrm{H}_{2} \mathrm{O}_{2}$ concentration in the flotte is calculated by titrating with $0.1 \mathrm{~N}$ sodium thiosulphate solution and based on the thiosulphate quantity spent. Every $1 \mathrm{ml} 0.1 \mathrm{~N}$ sodium thiosulphate solution spent corresponds to 1.7008 $\mathrm{mg} \mathrm{H}_{2} \mathrm{O}_{2}$ and $0.8 \mathrm{mg}$ active oxygen [11].

\section{RESULTS AND DISCUSSION}

When table 3 and figure 1 indicating the peroxide quantity depending on time from different prescriptions are examined, it is seen that the peroxide contraction decreased rapidly during first 15 minutes and the decrease rate in peroxide concentration reduces with the extension of the time. However, the degradation rate of hydrogen peroxide in R3 prescription consisting $\mathrm{NaOH}$ and zeolite along with the hydrogen peroxide in first 15 minutes is higher than the all other prescriptions. In first 15 minutes, a significant part of

Table 1

\begin{tabular}{|c|c|c|c|}
\hline \multicolumn{4}{|c|}{ PROCESS PRESCRIPTIONS AND PROCESS TERMS } \\
\hline Prescription 1 & Prescription 2 & Prescription 3 & Prescription 4 \\
\hline $\begin{array}{l}6 \mathrm{ml} / \mathrm{l} \text { Hydrogen peroxide } \\
2,5 \mathrm{~g} / \mathrm{l} \mathrm{NaOH} \\
\mathrm{pH} 11 \\
\mathrm{FO} 1 / 40 \\
60 \mathrm{~min} \text {. at } 95^{\circ} \mathrm{C}\end{array}$ & $\begin{array}{l}6 \mathrm{ml} / \mathrm{l} \mathrm{Hydrogen} \mathrm{peroxide} \\
2,5 \mathrm{~g} / \mathrm{l} \mathrm{NaOH} \\
1 \mathrm{~g} / \mathrm{l} \mathrm{stabilizer} \\
\mathrm{pH} 11 \\
\mathrm{FO} 1 / 40 \\
60 \mathrm{~min} \text {. at } 95^{\circ} \mathrm{C}\end{array}$ & $\begin{array}{l}6 \mathrm{ml} / \mathrm{l} \mathrm{Hydrogen} \mathrm{peroxide} \\
2,5 \mathrm{~g} / \mathrm{l} \mathrm{NaOH} \\
30 \mathrm{~g} / \mathrm{l} \mathrm{Zeolite} \\
\mathrm{pH} 11 \\
\mathrm{FO} 1 / 40 \\
60 \mathrm{~min} \text {. at } 95^{\circ} \mathrm{C}\end{array}$ & $\begin{array}{l}6 \mathrm{ml} / \mathrm{l} \text { Hydrogen peroxide } \\
30 \mathrm{~g} / \mathrm{l} \text { Zeolite } \\
\mathrm{pH} 6 \\
\mathrm{FO} 1 / 40 \\
60 \mathrm{~min} \text {. at } 95^{\circ} \mathrm{C}\end{array}$ \\
\hline \multicolumn{4}{|c|}{ Following Processes } \\
\hline \multicolumn{4}{|c|}{$\begin{array}{l}10 \mathrm{~min} \text {. rinse at } 95^{\circ} \mathrm{C} \\
10 \mathrm{~min} \text {. rinse at } 95^{\circ} \mathrm{C} \\
5 \mathrm{~min} \text {. cold rinse }\end{array}$} \\
\hline
\end{tabular}

Table 2

\begin{tabular}{|c|c|c|c|c|c|c|c|c|c|c|c|}
\hline \multicolumn{12}{|c|}{ ICP-MS ELEMENTAL ANALYSIS RESULTS OF THE NATURAL ZEOLITE } \\
\hline & $\begin{array}{c}\mathrm{Pb} \\
\mathrm{mg} / 10 \mathrm{~g}\end{array}$ & $\begin{array}{c}\mathrm{Ca} \\
\mathrm{mg} / 10 \mathrm{~g}\end{array}$ & $\begin{array}{c}\mathrm{Mn} \\
\mathrm{mg} / 10 \mathrm{~g}\end{array}$ & $\begin{array}{c}\mathrm{Ag} \\
\mathrm{mg} / 10 \mathrm{~g}\end{array}$ & $\begin{array}{c}\mathrm{Zn} \\
\mathrm{mg} / 10 \mathrm{~g}\end{array}$ & $\begin{array}{c}\mathrm{Cu} \\
\mathrm{mg} / \mathrm{g}\end{array}$ & $\begin{array}{c}\mathrm{Na} \\
\mathrm{mg} / 10 \mathrm{~g}\end{array}$ & $\begin{array}{c}\mathrm{Fe} \\
\mathrm{mg} / 10 \mathrm{~g}\end{array}$ & $\begin{array}{c}\mathrm{Mg} \\
\mathrm{mg} / 10 \mathrm{~g}\end{array}$ & $\begin{array}{c}\mathrm{Al} \\
\mathrm{mg} / 10 \mathrm{~g}\end{array}$ & $\begin{array}{c}\mathrm{K} \\
\mathrm{mg} / 10 \mathrm{~g}\end{array}$ \\
\hline $\begin{array}{l}\text { Natural } \\
\text { zeolite }\end{array}$ & 0,57 & 89,07 & 3,89 & - & - & - & 20,85 & 134,59 & 72,52 & 539,84 & 300,76 \\
\hline
\end{tabular}


THE CHANGE OF THE HYDROGEN PEROXIDE CONCENTRATIONS

\begin{tabular}{|c|c|c|c|c|}
\hline $\begin{array}{c}\text { Time } \\
\text { (min) }\end{array}$ & $\begin{array}{c}\mathbf{R}-1 \mathbf{H}_{\mathbf{2}} \mathbf{O}_{\mathbf{2}} \\
(\mathbf{m g})\end{array}$ & $\begin{array}{c}\mathbf{R}-2 \mathbf{H}_{\mathbf{2}} \mathbf{O}_{\mathbf{2}} \\
(\mathbf{m g})\end{array}$ & $\begin{array}{c}\mathbf{R}-3 \mathbf{H}_{\mathbf{2}} \mathbf{O}_{\mathbf{2}} \\
(\mathbf{m g})\end{array}$ & $\begin{array}{c}\mathbf{R}-4 \mathbf{H}_{\mathbf{2}} \mathbf{O}_{\mathbf{2}} \\
(\mathbf{m g})\end{array}$ \\
\hline 0 & 29.764 & 29.764 & 29.764 & 29.764 \\
\hline 15 & 16.1576 & 17.008 & 2.5512 & 17.008 \\
\hline 30 & 12.756 & 15.3072 & 1.7008 & 13.6064 \\
\hline 45 & 11.9056 & 12.756 & 1.7008 & 12.756 \\
\hline 60 & 9.3544 & 11.0552 & 1.7008 & 10.2048 \\
\hline
\end{tabular}

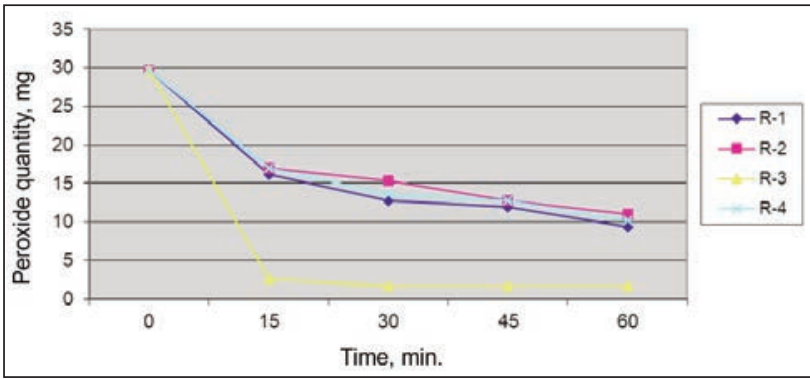

Fig. 1. Peroxide Quantity in the Baths Acquired by means of Peroxide Titration

the peroxide in the bath is degraded in R3 prescription. The degradation rates and characteristics of $\mathrm{R} 1$, R2 and R4 prescriptions are quite similar. The most significant difference of $\mathrm{R} 4$ prescription from $\mathrm{R} 3$ is its $\mathrm{pH}$. Alkalinity of the R3 prescription ( $\mathrm{pH} 11)$ accelerates the degradation rate together with zeolite. Degradation rate of peroxide of R4 is lower comparing to R3 prescription, because weak acidic environment $(\mathrm{pH} 6)$ of $\mathrm{R} 4$ enables the stabilization of hydrogen peroxide in spite of zeolite.

Here $\mathrm{H}_{2} \mathrm{O}_{2}$ oxides zeolite with its oxidizing effect and degrades itself, turns into water, on the other hand, the cage structure of zeolite dissolves as a result of oxidizing [12]. Regarding the antiperoxide enzymes and chemicals, it is intended to neutralize $\mathrm{H}_{2} \mathrm{O}_{2}$ as soon as possible in the end of the process in order to protect the cotton fabric from being damaged and eliminate their decreasing effects on dye efficiency, after $\mathrm{H}_{2} \mathrm{O}_{2}$ bleaching.

$\mathrm{H}_{2} \mathrm{O}_{2}$ concentration in the bath was assessed iodimetrically in every 15 minutes and point data are evaluated by means of regression analysis and the curves in the figures $2-5$ were acquired. Due to the fact that the line functions having the highest correlation coefficient was chosen while determining the line expressing the degradation ideally, the lines acquired can be as logarithmic, exponential or polynomial function. This shows that hydrogen peroxide can be dissolved in different ways depending on the process terms and flotte content [13].

$$
\ln \left(C_{t} / C_{0}\right)=-k \cdot t
$$

In this equality, $k$ shows rate constant of the reaction, $C_{0}$ - original concentration of the product reacting, $C_{t}$ - the concentration in the end of the $t$ time.
As a result of applying the data acquired as consequence of the titration to number (1) equality, the functions in figures $2-5$ are obtained and the values at table 3 obtained as a result of these function lines.

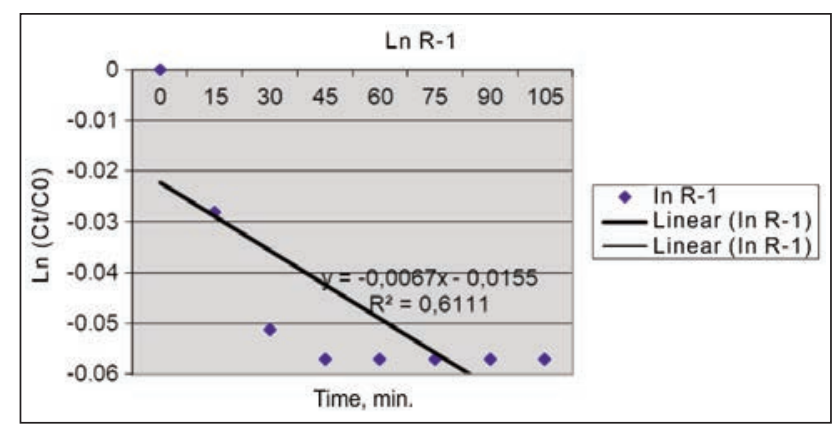

Fig. 2. Determining the reaction rate constant of the degradation of $\mathrm{H}_{2} \mathrm{O}_{2}$ in Prescription 1

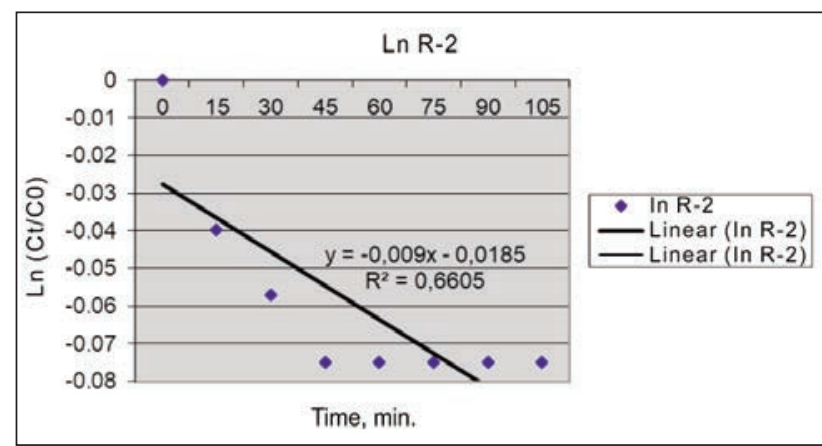

Fig. 3. Determining the reaction rate constant of the degradation of $\mathrm{H}_{2} \mathrm{O}_{2}$ in Prescription 2

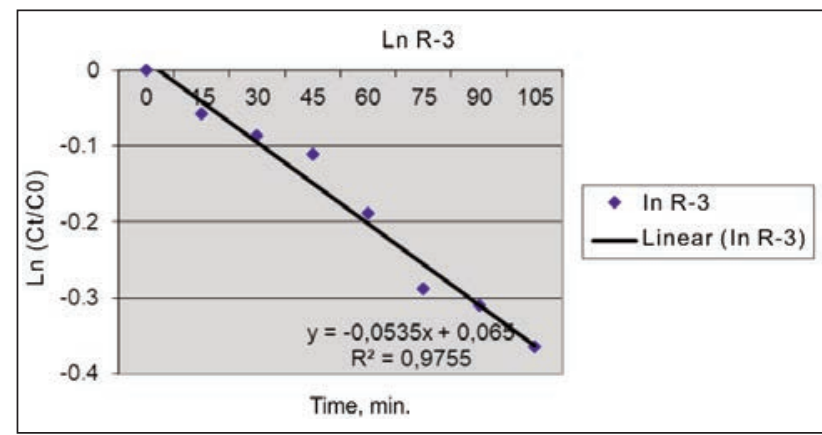

Fig. 4. Determining the reaction rate constant of the degradation of $\mathrm{H}_{2} \mathrm{O}_{2}$ in Prescription 3

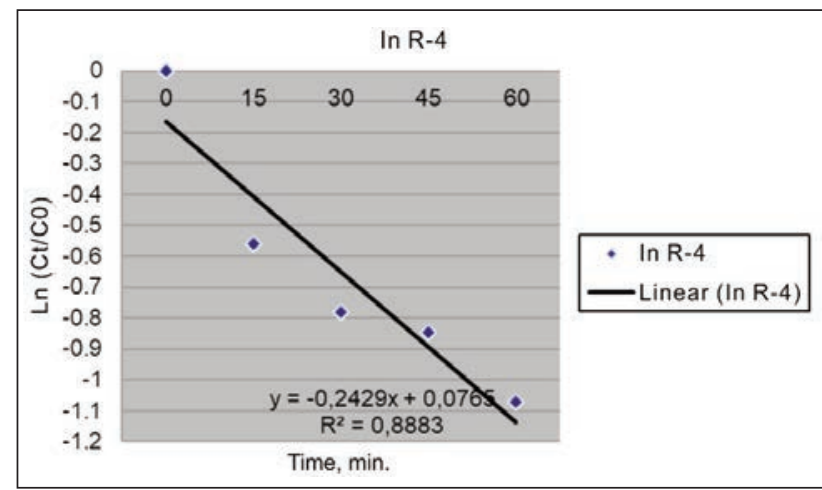

Fig. 5. Determining the reaction rate constant of the degradation of $\mathrm{H}_{2} \mathrm{O}_{2}$ in Prescription 4 
constant was 1.16 in this case when there were $\mathrm{H}_{2} \mathrm{O}_{2}$ and zeolite in flotte, because there was not any alkaREACTION RATE CONSTANTS OF $\mathrm{H}_{2} \mathrm{O}_{2}$ DEGRADATION IN PRESCRIPTIONS

\begin{tabular}{|c|c|c|}
\hline Prescriptions & PH & $\boldsymbol{k}\left(\mathbf{s n}^{-\mathbf{1}}\right) \cdot \mathbf{1 0}^{\mathbf{- 4}}$ \\
\hline 1 & 11 & 1.34 \\
\hline 2 & 11 & 1 \\
\hline 3 & 11 & 7.98 \\
\hline 4 & 6 & 1.16 \\
\hline
\end{tabular}
li addition. When Prescription 3 and 4 were reviewed, it was seen that the rate constant of degradation of $\mathrm{H}_{2} \mathrm{O}_{2}$ decreased rather a lot comparing to the alkali environment when any alkali was not added to the environment.

\section{CONCLUSIONS}

Zeolite is a natural mineral that is water-insoluble. The fact that zeolite is water-insoluble is a big problem during its usage in textile finishing processes

According to the table 4, rate constant in Prescription 2 was calculated as 1 when there were $\mathrm{NaOH}, \mathrm{H}_{2} \mathrm{O}_{2}$ and stabilizer in flotte. In prescription 3 , the degradation of $\mathrm{H}_{2} \mathrm{O}_{2}$ accelerated and rate constant reached 1.34 when there were only $\mathrm{NaOH}$ and $\mathrm{H}_{2} \mathrm{O}_{2}$ in flotte in Prescription 2. There was $\mathrm{NaOH}, \mathrm{H}_{2} \mathrm{O}_{2}$ and zeolite in flotte in Prescription 3. In this case, the degradation of $\mathrm{H}_{2} \mathrm{O}_{2}$ accelerated and rate constant reached 7.98. When Prescription 2 and Prescription 3 were reviewed it was seen that average zeolite addition accelerated the degradation of $\mathrm{H}_{2} \mathrm{O}_{2}$ almost 6 times more. This situation shows us clearly that zeolite can be used as $\mathrm{H}_{2} \mathrm{O}_{2}$ killer in $\mathrm{H}_{2} \mathrm{O}_{2}$ bleaching. When Prescription 4 was reviewed, $\mathrm{pH}$ was 6 and the rate because any homogeneous application cannot be done on the surface of the textile material.

This study shows us that we can use the natural zeolite as hydrogen peroxide killer in hydrogen peroxide bleaching process, however, there is a need of optimization in terms of preparing the prescriptions, and a mechanism design which will have a special place in the machine and which will enable the zeolite to move through flotte without dissolving in bleaching bath.

And use of the natural zeolite as hydrogen peroxide killer in hydrogen peroxide bleaching process is a better alternative because Turkey has a large amount of zeolite reserve.

\section{REFERENCES}

[1] Ahn, B.J., Kondo, R., Sakai, K., Effect of activator on hydrogenperoxidebleaching of White ledger, In: Ind. Chem., 2001, 5(7), 285-291

[2] Brooks, R.E., Moore, S.B., Alkaline hydrogenperoxidebleaching of cellulose, In: Cellulose, 2000, 7, 263-286

[3] Kumbasar, E.P., Körlü, A.E., Can, C., The effects of activator on whiteness and hydrophility during the hydrogen peroxide bleaching, In: Tekstil ve Konfeksiyon, 2011, 1, 50-57

[4] Westbroek, P., Kiekens, P., Electrochemical behaviour of hydrogen peroxide oxidation: kinetics and mechanisms, In: Anayltical electrochemistry in textiles, Woodhead Publishing Limited, Cambridge, 2005, 92-94

[5] Eren, H.A., Aniş., P., Yılmaz, D., Kirişci, Ş., İnkaya, T., Combined used of laccase, ozone, and hydrogen peroxide for cotton bleaching, In: Tekstil ve Konfeksiyon, 2009, 4, 299-303

[6] Rouette, H.K., Letter h", Enyclopedia of textilefinishing, Springer-Verlag, Heidelberg, 2002, 82-86 (cd book)

[7] Karmakar, S.R., Bleaching of Textiles Chemical Technology in the Pre-Treatment Processes of Textiles, Elsevier, Amsterdam, 1999, 170-172

[8] Cai, J.Y., Esans, D.J., Guadine derivatives used as a peroxide activators for bleaching cellulosic textiles, In: Color Technology, 115-118

[9] Özaydın, S., Doğal Klinoptilolitlerin Türkiye'deki Kullanım Olanakları ve Gördes Klinoptilolitlerinin Isıl Özelliklerinin Belirlenmesi Üzerine Bir Araştırma, Ege Üniversitesi, Fen Bilimleri Enstitüsü, Doktora Tezi, 2005

[10] Finnegan, D., Stock, K., Dunn, L., Peroxide Bleaching Using Zeolites Part I: Peroxide Decomposition, In: Appita Journal, 1998, 51, 219-223

[11] Bilgin, E., Selüloz Esaslı Kumaşlarda Ön Terbiye Iş̧/emleri Sırasında Meydana Gelen Kimyasal Zararlar ve Analiz Yöntemleri, Ege Üniversitesi Fen Bilimleri Enstitüsü, Yüksek Lisans Tezi, 2003

[12] Dyhr, K., Sterte J., Effects of Zeolite Addition on the Manganese Catalyzed Decomposition of Hydrogen Peroxide, In: Journal of Porous Materials, 1999, 6, 275-282

[13] Kleinscheck, K.S., Golcer, M., Ribitsch, V. Dolecek, V., An alternative way to monitor $\mathrm{H}_{2} \mathrm{O}_{2}$ decomposition in bleaching solutions, In: Textile Res. J., 1998, 68, 5, 320-326

\section{Authors:}

\section{CANDAN AKCA}

Celal Bayar University, Salihli Vocational School, Textile Technology Department, Salihli, Manisa, Turkey

\section{Corresponding author:}

CANDAN AKCA

e-mail: candanakca@yahoo.com 


\title{
Fire safety in textile industries - A Review
}

\author{
DOI: $10.35530 / I T .070 .06 .1615$
}

\section{ABSTRACT - REZUMAT}

\section{Fire safety in textile industries - A Review}

Over the past decades, textile industries are playing an important role in the Indian economy, and moreover it is the second largest revenue source for the country. The textile industry is the only industry that offers massive employment for both skilled and unskilled labour. Fire accidents cost hundreds of workers' lives and livelihoods along with huge equipment and material loss. The stipulation of proper safety system would be the only option to increase the production rate and quality of the product which in turn amplify the profit and good will of the company. In spite of various initiatives taken to prevent fire accidents in the textile industry, there are still a significant number of fire occurrences in this industry. Fire accident is the major source of accident in case of textile industries, and preventing the fire accident would be the first and foremost choice and also it is mandatory to alleviate the fire accidents to safe guard raw materials and employees. This paper presents a review on various hazards in textile industries. This article intends at studying each of these issues in textile industries, along with the existing possible solutions for these problems. This study is essential in exposing safety concerns in factories around the world.

Keywords: cotton, machinery, risk, combustion, precaution

\section{Siguranța privind incendiile în industria textilă - studiu bibliografic}

În ultimele decenii, industria textilă joacă un rol important în economia indiană și, în plus, este a doua cea mai mare sursă de venit pentru această țară. Industria textilă este singura care oferă locuri de muncă, atât pentru personalul calificat, cât și cel necalificat. Incendiile afectează sute de vieți omenești și traiul muncitorilor, alături de pierderi mari de echipamente și materiale. Stipularea unui sistem de siguranță adecvat ar fi singura opțiune de a crește productivitatea și calitatea produsului care, la rândul său, mărește profitul și bunăstarea companiei. În ciuda diferitelor inițiative luate pentru prevenirea incendiilor în industria textilă, există încă un număr semnificativ de cazuri de apariție în această industrie. Incendiul este principala sursă de accident în industria textilă, iar prevenirea acestuia ar fi prima și cea mai importantă alegere, pentru a asigura paza materiilor prime și a angajaților. Acest studiu prezintă o analiză asupra diverselor pericole din industria textilă. Acest articol are ca scop studiul fiecărei probleme din industria textilă, împreună cu soluțiile posibile existente pentru acestea. Studiul este esențial pentru expunerea problemelor de siguranță în fabricile din întreaga lume.

Cuvinte-cheie: bumbac, utilaje, risc, ardere, prevenție

\section{INTRODUCTION}

In India, textile industries play an important role in the economic life of the country. The GDP generated in India has been fund to boost up the worldwide business to a greater extent as it has brought high revenue. The textile industry contributes 14 percent to the total industrial production in India and hence proved itself as leading sector in Indian earning and it has also claimed to be the biggest revenue earners in terms of foreign exchange among other sectors in India. Despite the economic growth and bright prospects, textile industries are facing challenges in the form of industrial accidents especially fire accidents [1]. Majority of fire accidents occur as a result of carelessness and elimination. The fire is the most unmanageable and the biggest danger to the textile industry [2]. The main causes of fire include static electricity, overheating, human error, atmospheric conditions and machine failures [3]. The workers are not aware of health and safety as they are not properly educated and also the management does not give due importance to promote Occupational Health and Safety in textile industries [4]. The problems can be best avoided by in-depth study and understanding of the manufacturing process and the environment. Hazards in cotton industry are of varying degree right from the inception stage till its finishing process. Understanding the areas of risks in the storage of textile materials and goods as well as the related factors can largely help in the prevention of fire accidents [5]. The textile flammability is generally defined with processes such as burning rates, flame spread rates, characteristics for ignition [6]. The thermal protection of the fabric is influenced by weight, thickness, construction, water vapour, permeability and these properties are related to each other [7]. 


\section{HISTORY AND DEVELOPMENT OF TEXTILE INDUSTRY}

In India, during 400 AD the silk was introduced, while cotton traces back to $3000 \mathrm{BC}$ [8]. The traditional textile industry of India was virtually decayed during the colonial regime. The cotton textile industry, however, made its real beginning in Bombay, in 1850s. The cotton textile industry made rapid progress in the second half of the nineteenth century and by the end of the century there were 178 cotton textile mills. Globalization has had a positive impact on textile exports of India. Countries producing and exporting textiles have increased investment in spinning and weaving equipment [9]. The Indian textile and clothing industry provides a valuable wealth of craftsmanship both skilled and semi-skilled work force which is the major contributor towards the development of apparel units.

\section{LITERATURE REVIEW}

Wan [10] reported on implementing the statutory elements of an occupational safety and health management system model in the working environment of a textile testing laboratory in Hong Kong and suggested that suitability of the established occupational safety and health management system has to be measured and monitored so that improvements could be identified. According to Padmini and Venmathi [11] the causes of fire accidents in Tirupur garment industries include electric short circuit, faulty electrical wiring, smoking materials, boiler explosion, kitchen stove and carelessness. Akhter et al. [12] discussed problem of health and safety issues of female workforce of garment industries in Bangladesh based upon the industry environment, causes of fire accident and their medical facilities.

Nazia Malik et al. [13] studied the role of hazards control measures in Occupational Health and Safety in textile industry using multistage random sampling technique. Wen-hui Ju [14] summarized the fire safety aspects referring to a hundred cotton logistics warehouse fires, based on the relevant provisions of the cotton logistics warehouse. Although in recent years, there have been significant efforts to improve the structural elements of fire safety; there still is a large scope to improve the fire safety in the textile industries [15].

\section{MAJOR SECTORS IN TEXTILE INDUSTRY}

The world's second largest industry is the textile industry next to agriculture, with massive employment for both skilled and unskilled labour. Textile industry includes five major sectors namely ginning, spinning, weaving, dyeing and garment industry [16]. Despite the benefits, workplace safety in this highly labor intensive industry is not satisfactory [17]. Ginning industry is the main sector subject to fire accidents due to reasons like electrical sparks and storing of raw cotton in sun light. Smoking in such areas can cause fire very easily. Textiles that are usually organic may be readily burnt and can actively spread flame. Weaving creates a fair amount of lint, dust and fibre flying which can represent fire hazards if the fibres are combustible [18]. The fire hazards found in a dye works are the flammable solvents used in the processes and certain flammable dyestuffs. The textile industry produces various products out of different natural and artificial fibres. The production of cloth holds many risks of fire. Sparks, glowing embers or overheated particles can be generated along the entire production chain and easily cause fire and dust explosions. Fires that broke out in the storage place of textile materials and textile goods, especially in open storage places, accounts for a relatively large proportion in the fire cases occurred in warehouses.

\section{FIRE HAZARDS IN VARIOUS UNITS OF TEXTILE INDUSTRY}

All the materials that are used in the textile industry are flammable to some extent. The hazards happening in the textile industries are mechanical hazards, physical hazards, chemical hazards, ergonomic hazards and physiological hazards.

In ginning industry, the ginning machine separates cotton fiber in the raw cotton from the cotton seeds for making yarn. Electrical problems in the ginning machine, man made errors, sparks from the machine, and exposure of cotton to sunlight forms the reasons for fire incidents.

In spinning industry, cotton fiber is fabricated in to clothes. Since the raw cotton catches fire easily, the fire hazards in spinning mills are more when compared to the other sectors of textile industry.

When yarn is passed through electrical heating elements in yarn singeing machines to burn out the protruding fibers, electrical spark can be caused. In preparing pigment for printing the fabric, about $70 \%$ of kerosene if used together with other binders. The printed fabric, containing this percentage of kerosene, is then evaporated and fabric is dried. Probabilities of disastrous explosions with resulting fires exist in this process.

Fires due to electrical faults have been more in cotton industry than any other industry. Cotton fluff is easily ignited by a spark by a faulty installation, which could be the cause of a serious fire. Modern machineries are driven by electricity and require power at high pressure. Accumulation of heat in the layer of dust and lint leads to the sudden acceleration of the exothermic oxidation reactions leading eventually to fire spots. These fire spots can migrate through a layer of dust and when they encounter a flammable substance they can trigger fires [19]. 


\section{CAUSES OF FIRE IN TEXTILE INDUSTRY}

Industrial fires and explosions cost companies and governments billions of rupees every year, not to mention the loss of life, which can't be described in monetary terms. The main causes in textile industries include the following.

Combustible Raw Materials: The basic raw material used in textile industries is raw cotton which is itself a combustible material. Cotton is capable of getting ignited even with a small spark and cotton fire spreads very rapidly and causes serious consequences. Other raw materials including bleaching agents, dyes and chemicals can also cause fire.

Sparks: Sparks find their way into dust collector systems from the industrial process. They enter through the hoods and ducts in the collector system.

Type of Building: Nature of construction of a cotton textile industry may pose fire hazards when fire proof class of construction is not made and largely depends on nature of external walls and roof of a building.

Spontaneous combustion: Due to spontaneous combustion of coal in the coal yard and excessive heat in the boiler of the factory, explosion can occur and subsequently break out in the factory. In thermal fluid heaters, oil is heated, circulated, recovered and re-circulated. This process is also susceptible to explosion hazard and subsequent fire.

Electrical Machineries: Faults in electrical circuits can easily ignite the cotton fluff which can cause a serious fire. Heat produced due to the operations of machineries and electrical installation can lead to fire.

\section{PREVENTION OF FIRE ACCIDENTS IN TEXTILE INDUSTRY}

It is the essential to prevent the fire source from warehouses through personnel management and fire protection technology. In case of fire incident, owner, management, government and employees are responsible for controlling the same [20].

The precautionary measures to be adopted at the time of stacking the cotton bales include adequate ventilation and proper stacking of the bales, temperature and humidity control, equipping the warehouse with thermometer and hygrometer to keep the temperature below $308 \mathrm{~K}$ and the humidity below $70 \%$, preventing the possibilities of spontaneous heat and combustion and storing hazardous chemicals away from non-hazardous chemicals. The transportation vehicles, storage vehicles, equipment in warehouses must be installed with flameproof enclosure or choke to ensure no sparks.

The type of building plays an important role in preventing fire in textile industry. Fire risk can be minimized by avoiding materials like wooden partitions, roof linings and false ceilings.

The coal storages are to be kept away from the surrounding and boiler houses must be segregated from the adjacent blocks. Electrical installations must comply with standard requirements and frequent maintenance and inspection of electrical equipments are required. Good housekeeping practices must be observed inside and outside the industry to prevent fire.

Automatic fire alarm systems must be installed to control the spread of the fire or even extinguish fire by automatic sprinkler system.

\section{CONCLUSION}

The article sums up the fire safety issues related to textile industries by analyzing the causes and situations in various sectors of a cotton textile mill leading to fire hazards. The risk of fire pertaining to the materials, type of building, manufacturing processes, machineries and electrical equipments used were discussed. The preventive measures that can be adopted to avoid the incidence of fire were also presented.

\section{REFERENCES}

[1] Mizanuzzaman, M., Loss and Damage Assessment in the Context of Fire Hazards: A Study on Selected Garment Factories in Bangladesh, In: International Journal of Finance and Banking Research, 2016, 2, 2, 24-39

[2] Vasim, K., Avikumar, S., Karbhari, T., The Pioneer Study on Identification of Fire Hazards in Cotton Ginning Industries of Nandurbar Region of Maharashtra, In: International Journal of Scientific Research, 2013, 2, 10, 1-4

[3] Shanmuga, S.P., Raj, Pradeesh T. S., Aravind, Rajand, Jayakrishna, K., A Case Study on Investigation of Fire Accident Analysis in Cotton Mills, 14th international Conference on Humanizing Work and Work Environment, HWWE-2016

[4] Praveen, Kumar, M., Mugundhan, K., Visagavel, K., Occupational Health \& Safety In Textile Industry, In: International Journal of Research in Engineering and Technology, 2014, 3, 11, 168-172

[5] Jian-yun, M., Analysis on the Fire Risk Existing in the Storage of Textile Materials and Textile Goods, In: Procedia Engineering, 2014, 71, 271-275

[6] Gunaydin, K.G., Ceven, E.K., A research on tensile and abrasion properties of fabrics produced from conventional and fire resistant type polyester yarns, In: Industria Textila, 2017, 68, 6, 407-414, https://doi.org/10.35530/ IT.068.06.1484

[7] Muge, D., Ender, Y.B., Yavuz, S., Taner, A., Neural network based thermal protective performance prediction of three-layered fabrics for firefighter clothing, In: Industria Textila, 2019, 70, 1, 57-64, https://doi.org/10.35530/ IT.070.01.1527 
[8] Divya, P., Solanki, A role of textile industry in Indian economy, In: National Journal of Advanced Research, 2017, 3, 3, 60-65

[9] Noopur, T., Eswara, R.E., A Study on Emerging Trends in Textile Industry in India, In: International Journal of Advancements in Research \& Technology, 2013, 2, 7, 267-276

[10] Kan, C.W., Occupational Safety and Health Management System in Textile Industry - A Continual Improvement Approach, RMUTP International Conference: Textiles \& Fashion 2012, July 3-4, 2012, Bangkok Thailand

[11] Padmini, D.S., Venmathi, A., Unsafe Work Environment in Garment Industries, Tirupur, India, In: Journal of Environmental Research and Development, 2012, 7, 1A, 569-575

[12] Akhter, S., Salahuddin, A.F.M., Iqbal, M., Abma, M., Jahan, N., Health and Occupational Safety for Female Workforce of Garment Industries in Bangladesh, In: Journal of Mechanical Engineering, 2010, 41, 1, 65-70

[13] Nazia, M., Ashfaq, A.M., Tariq, S.P., Saira, A., Tanvir A., Role of Hazard Control Measures in Occupational Health and Safety in the Textile Industry of Pakistan, In: Pakistan Journal of Agriculture and Science, 2010, 47, 1, 72-76

[14] Wen-hui, J., Study on Fire Risk and Disaster Reducing Factors of Cotton Logistics Warehouse Based on Event and Fault Tree Analysis, In: Procedia Engineering, 2016, 135, 418-426

[15] Hasan, M., Mahmud, A., Risks Management of Ready-Made Garments Industry in Bangladesh, In: International Research Journal of Business Studies, 2017, 10, 1, 1-13

[16] Karupannan, K.P., Arularasu, M., Devadasan, S.R., Study on Safety Training Programme in Textile Industries, In: International Journal of Control Theory and Applications, 2017, 10, 20, 221-230

[17] Wadud, Z., Huda, F.Y., Fire Safety in the Readymade Garment Sector in Bangladesh: Structural Inadequacy Versus Management Deficiency, In: Fire Technology, 2017, 53, 2, 793-814

[18] Sudha, B., Meenaxi, T., Occupational health hazards in textiles industry, In: Asian Journal of Home Science, 2014, $9,1,267-271$

[19] Olimpiu, S., Dorina, P., Marin, S.N., Alexandru, L.C., Danut, G., Gabriel, T., Catalin, P., Research on the possibilities of reducing the effects of shock waves in case of explosions in environments with dust and textile suspended particulate matter, In: Industria Textila, 2018, 69, 3, 243-248, https://doi.org/10.35530/IT.069.03.1480

[20] Hasan, M.., Mahmud, A., Islam, S., Deadly Incidents in Bangladeshi Apparel Industry and Illustrating the Causes and Effects of These Incidents, In: Journal of Finance and Accounting, 2017, 5, 5, 193-199

\section{Authors:}

PONNUSAMY VENKATARAMANAN ${ }^{1}$, PAULRAJ PRATHAP ${ }^{1}$, PALANISAMY SIVAPRAKASH ${ }^{2}$, KANCHANA SIVAPRAKASH $^{3}$

${ }^{1}$ Anna University, Hindusthan College of Engineering and Technology, Department of Mechanical Engineering, Othakalmandapam via, 641032, Coimbatore, India

e-mail: venkataramananp80@gmail.com; prathu135@gmail.com

${ }^{2}$ Anna University, Dr.N.G.P. Institute of Technology, Department of Mechanical Engineering, 641048, Coimbatore, India

e-mail:drpsivaprakash@gmail.com

${ }^{3}$ Anna University, Sri Ramakrishna Engineering College, Department of Civil Engineering, 641022, Coimbatore, India

e-mail: kash10304@gmail.com

Corresponding author:

PALANISAMY SIVAPRAKASH

e-mail: drpsivaprakash@gmail.com 


\title{
Bivariate analysis of the hydrophobic textiles obtained by plasma treatment
}

\author{
DOI: $10.35530 / I T .070 .06 .1476$
}

RALUCA MARIA AILENI

LAURENTIU DINCA

SILVIA ALBICI

LILIOARA SURDU

\section{ABSTRACT - REZUMAT}

\section{Bivariate analysis of the hydrophobic textiles obtained by plasma treatment}

This paper presents aspects concerning the bivariate analysis of the textiles surfaces treated by RF plasma technologies (Ar RF plasma and SF6 RF plasma) to obtain the hydrophobic effect. Besides this, it was studied the remnant or temporary hydrophobic effect obtained by polytetrafluoroethylene (PTFE) thin-film by physical vapor deposition (PVD) technique and SF6 RF plasma technique. In this paper, there are presented the bivariate analysis of the parameters and characterization of hydrophobic textile samples (cotton $100 \%$ with mass $401 \mathrm{~g} / \mathrm{m}^{2}$ ) by investigation of the water contact angle using the device VCA OPTIMA and resistance to surface wetting by James Heal spray tester. The morphological modification of the textile was evaluated by scanning electron microscope with magnification x8000. Following these investigations there has been observed that the treatment with polytetrafluoroethylene is even more harmful to the environment, offering a hydrophobic effect resistant in time, for approximative 101 days, and the treatment by SF6 RF plasma confer a temporary effect for 24 hours.

Keywords: plasma, bivariate analysis, hydrophobicity, contact angle, resistance to surface wetting

Analiza bivariată a materialelor textile hidrofobe obținute prin tratarea în mediu de plasmă

Această lucrare prezintă aspecte privind analiza bivariată a suprafețelor textile tratate prin intermediul tehnologiilor RF plasmă (RF plasmă Ar şi RF plasmă SF6), pentru a obține efectul hidrofob. În plus, a fost studiat efectul remanent sau temporar hidrofob obținut prin depunerea unei pelicule subțiri de politetrafluoroetilenă (PTFE), prin tehnologia de depunere fizică sub formă de vapori (PVD) și RF plasma SF6. În această lucrare, sunt prezentate analiza bivariată a parametrilor și caracterizarea probelor textile hidrofobe (bumbac 100\% cu masă $401 \mathrm{~g} / \mathrm{m}^{2}$ ), prin determinarea unghiului de contact la apă cu ajutorul dispozitivului VCA OPTIMA și a rezistenței la umezire prin metoda Spray test (James Heal). Evaluarea modificărilor morfologice a fost realizată prin microscopie electronică SEM cu magnifiere x8000. În urma acestor investigații, s-a observat că tratamentul cu politetrafluoroetilenă este dăunător pentru mediu şi conferă un efect de hidrofobizare rezistent în timp pentru aproximativ 101 zile, iar tratamentul cu RF plasmă SF6 are un efect de hidrofobizare temporară pentru 24 de ore.

Cuvinte-cheie: plasmă, analiza bivariată, hidrofobicitate, unghiul de contact, rezistența la umezire

\section{INTRODUCTION}

The challenges to finding solutions for surface functionalization by low cost in materials, energy, and time, boost the research in textile to multidisciplinarity and new versatile technologies such as RF plasma technology or magnetron sputtering to deposit thinfilm on the textile surface. The new approach of PVD coating on the cotton textile surface [1-3] offers a new perspective for textile functionalization to obtain antibacterial [4], the hydrophobic [5-7], hydrophilic or conductive effect [8-9]. The magnetron sputtering [10] is high-rate vacuum coating technique for depositing metals, alloys, and compounds on the materials surface, with film thicknesses. The coating techniques based on vacuum deposition are chemical vapor deposition (CVD) [11] and physical vapor deposition (PVD) [12-14]. By CVD coating technology, a thin film was obtained by the chemical reaction between precursors. The inconvenient is that this technique requires a high-temperature medium. By PVD technique, the surface can be modified by evaporation and sputtering. This technique is eco-friendly and dry technology [15-17] that can be used for obtaining functional surfaces with hydrophobic, hydrophilic, antibacterial, electrical, mechanical properties improved. However, the most commonly used plasma technology for textile functionalization, such as hydrophobization and hydrophilic [18-19], still remains low pressure RF plasma technology.

\section{EXPERIMENTAL PART AND METHODS}

The goal of our experiments was to investigate the hydrophobic character, permanent or temporary, obtained by using RF plasma treatments based on Argon (Ar) and fluoropolymers such as PTFE (Polytetrafluoroethylene) or plasma treatments based SF6 (Sulfur hexafluoride). In order to achieve these objectives there were used several parameters that define the samples (cotton $100 \%$, mass $401 \mathrm{~g} / \mathrm{m}^{2}$ ) and experiments such as gas flow rate $(15-120 \mathrm{sccm})$, pressure $\left(1.0 \times 10^{-3}-8.8 \times 10^{-4} \mathrm{mbar}\right)$, time (5-15 $\left.\mathrm{min}\right)$, power $(40 \mathrm{~W} ; 80 \mathrm{~W}$ ) and gas type (SF6 or Argon for magnetron sputtering used for PTFE thin-film deposition). By RF plasma Ar and PTFE were prepared 
9 samples $\left(P_{1}-P_{9}\right)$ and by SF6 RF plasma were provided 6 samples $\left(P_{10}-P_{15}\right)$.

To investigate the resistance to surface wetting using a spray test qualitative method (SR EN ISO 4920: 2013) that allows appreciating, by ISO scale or photographic scale AATCC, the resistance of the fabric to surface wetting by water at temperature $21^{\circ} \mathrm{C}$. Using this method several tests were performed during 101 days. Figure 1 presents the values obtained by photographic scale AATCC during the 101 days for samples treated with PTFE in Ar RF plasma, and figure 2 presents the values for 3 days for samples treated with $\mathrm{SF}_{6} \mathrm{RF}$ plasma. By performing these tests, we observed that the fabric treated in RF plasma acquires a temporary hydrophobic character. Also, in the case of $\mathrm{SF}_{6} \mathrm{RF}$ plasma, the hydrophobic character was active only for $24 \mathrm{~h}$, and after 48 hours the fabrics become initial hydrophilic characters (figure 2). However, in case of the treatments obtained by $\mathrm{Ar}$ plasma with thin-film PTFE deposition the hydrophobic character (figure 1) was longtime remnant and on several samples was still active after 101 but with very weak values.

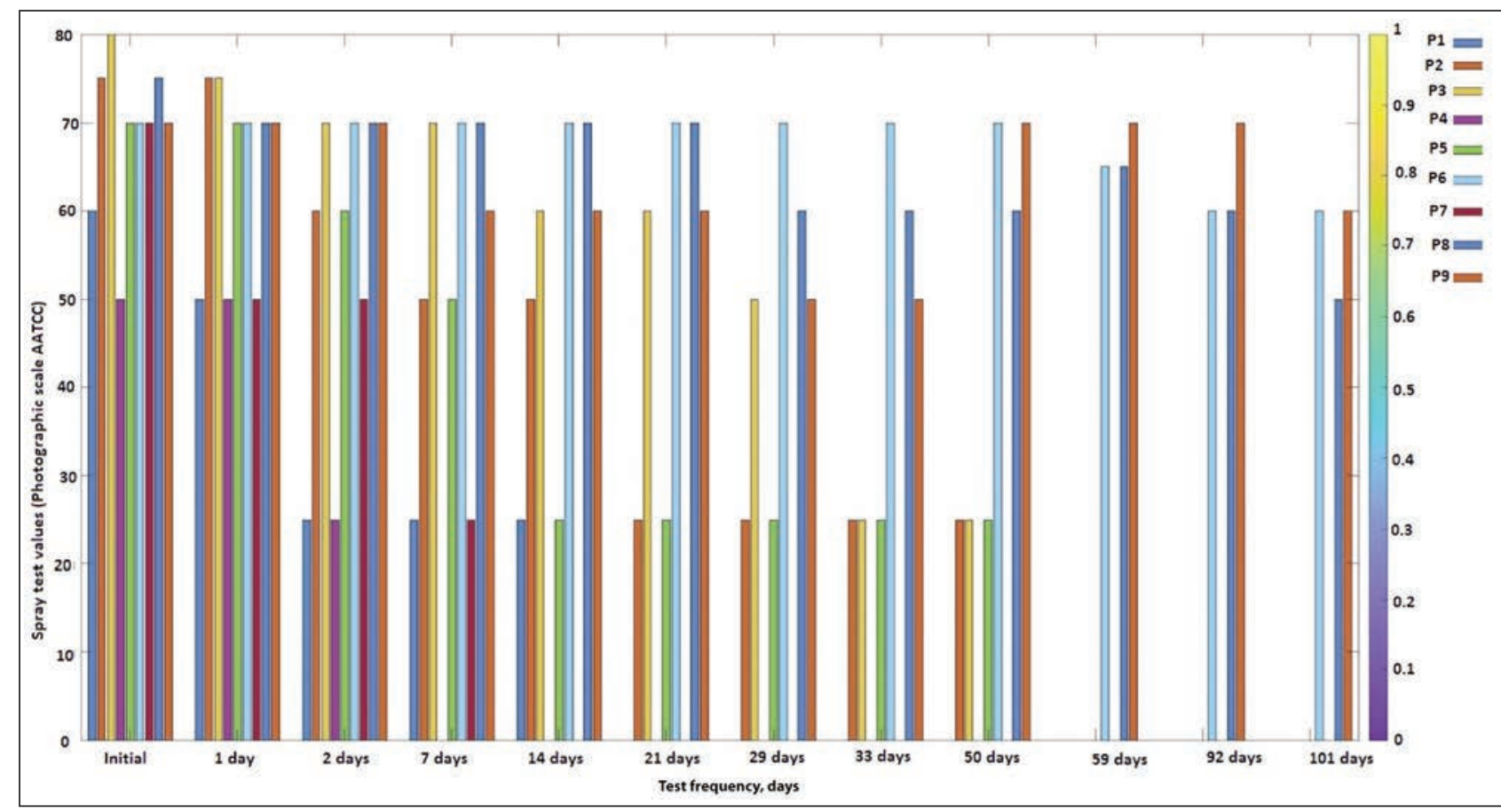

Fig. 1. Spray tests for samples $P_{1}-P_{9}$ treated in Ar plasma and coated with PTFE

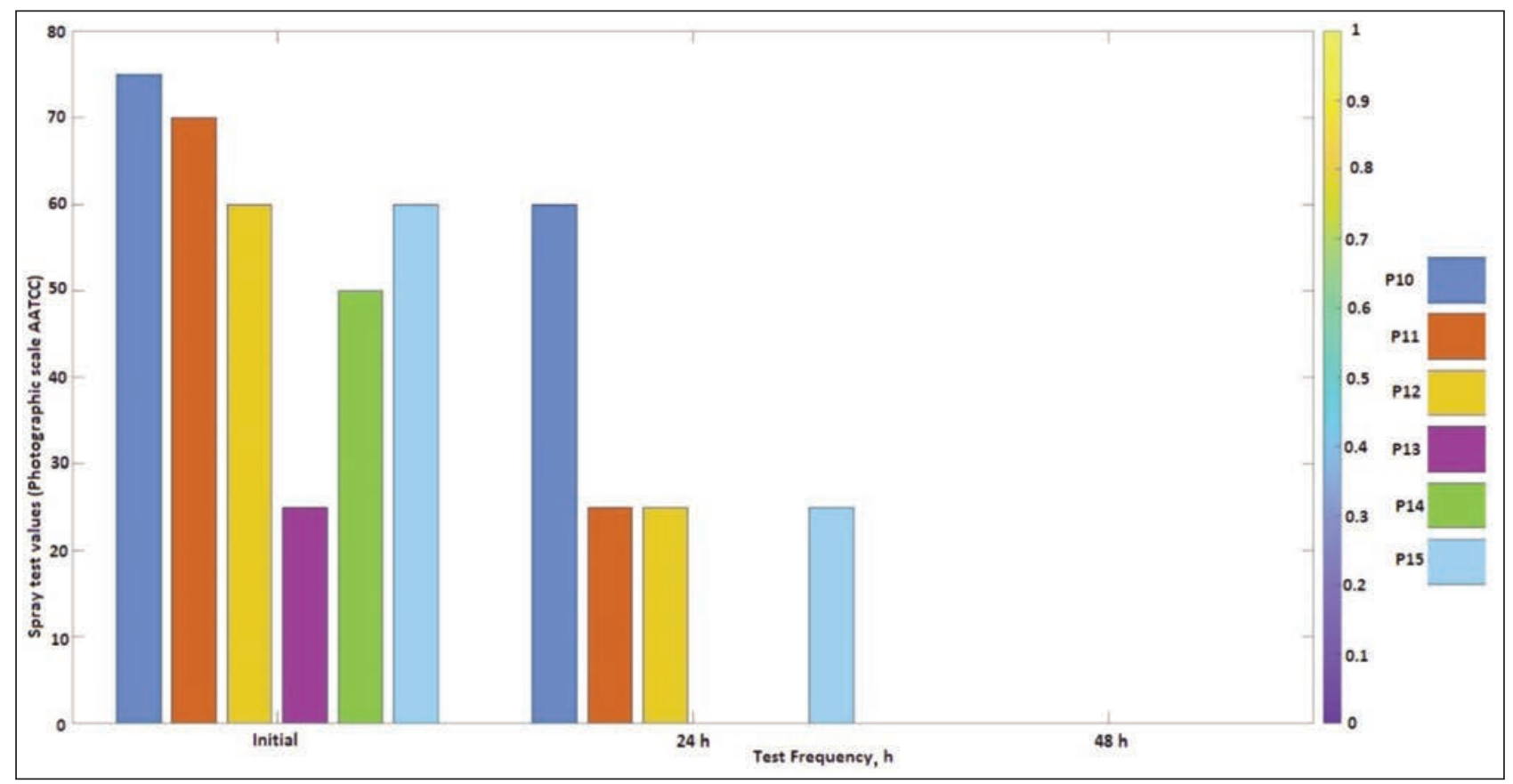

Fig. 2. Spray tests for samples $\mathrm{P}_{10}-\mathrm{P}_{15}$ treated using $\mathrm{SF}_{6} \mathrm{RF}$ plasma 


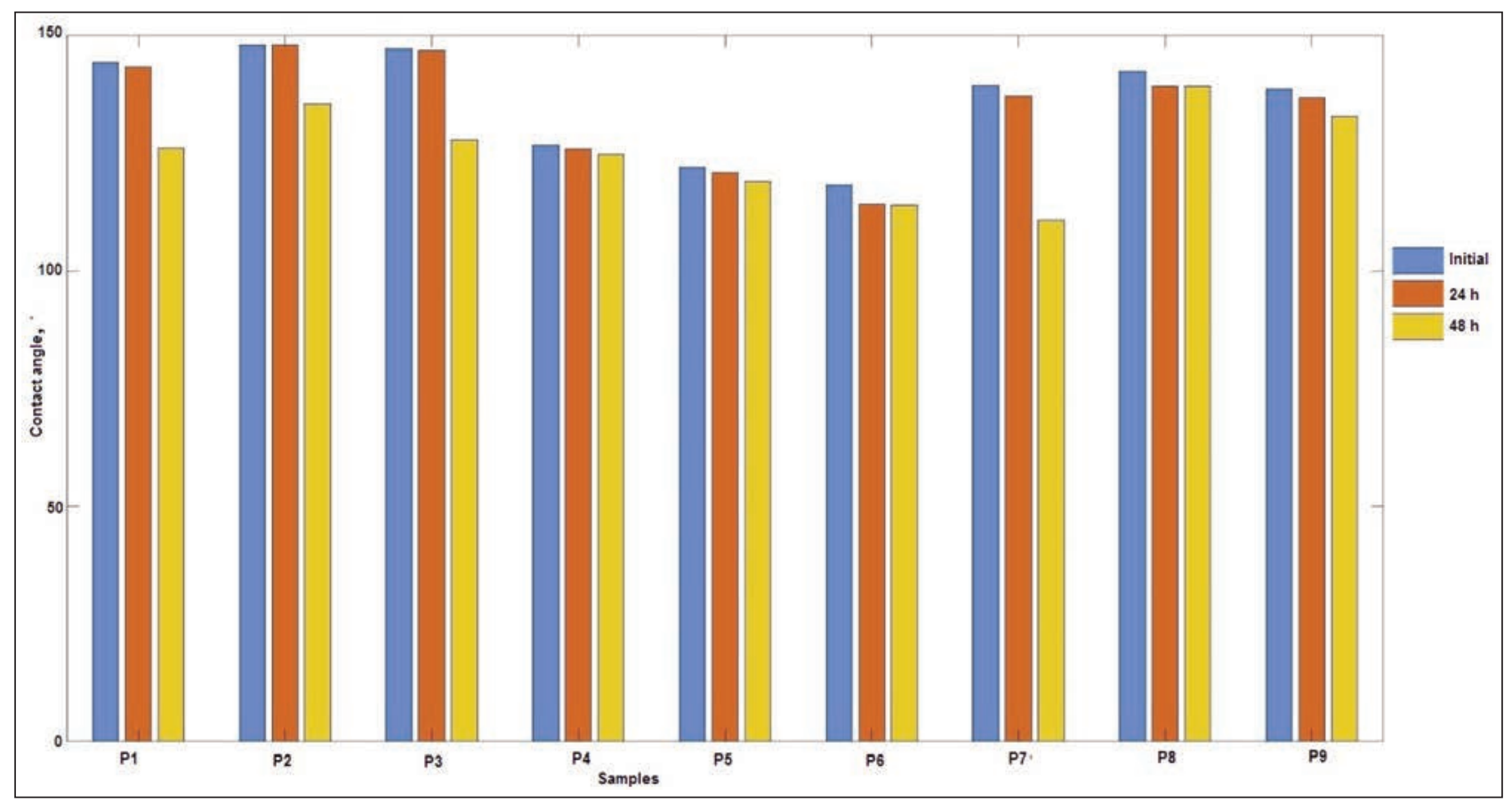

Fig. 3. Contact angles for samples P1-P9 for 3 days

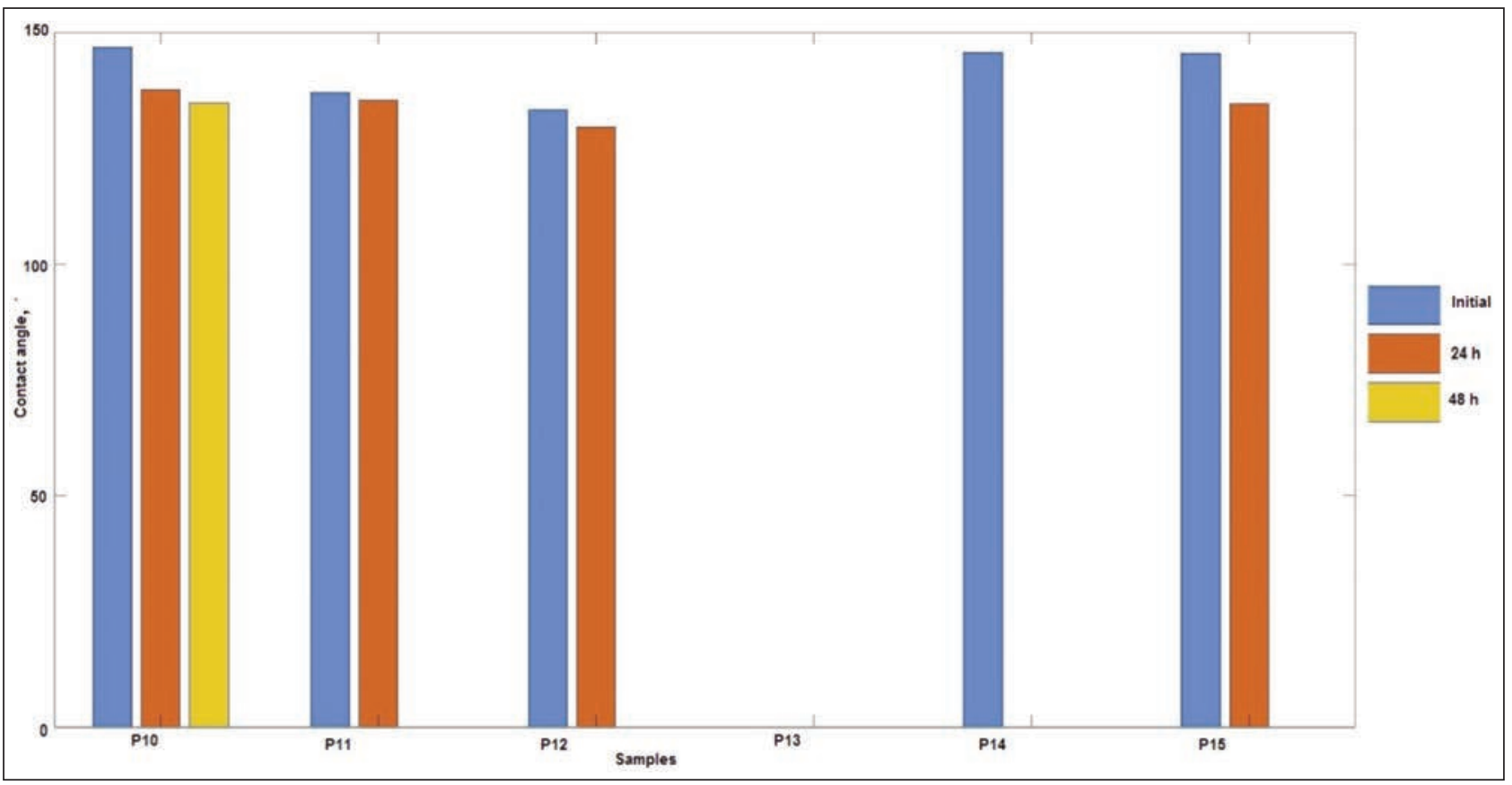

Fig. 4. Contact angles for samples P10-P15 for 3 days

Also, we analyzed the contact angle for samples with hydrophobic properties obtained by Ar RF plasma with thin-film PTFE (figure 3) and $\mathrm{SF}_{6}$ RF plasma (figure 4). The thickness of the PTFE thin-film was varied using the argon flow injected during the sputtering process (in the range $80-120 \mathrm{sccm}$ ), and respectively by the deposition time (5-15 min).

The hydrophobic effect of the coated textile surfaces was investigated by the water contact angle using the device VCA OPTIMA (figure 5) according to ASTM D7490-08 (table 1) and spray rating tester (resistance

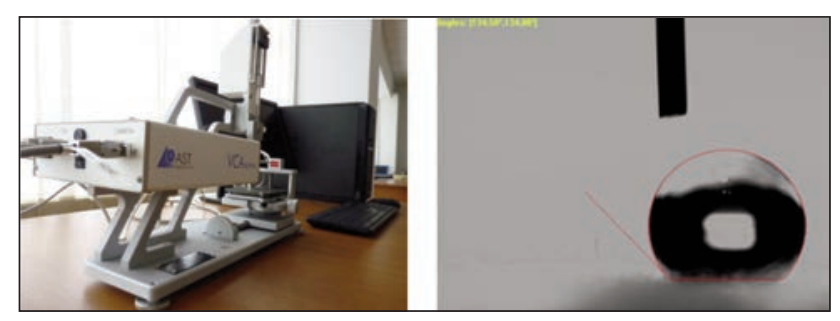

Fig. 5. Optima VCA - contact angle test

to surface wetting tester - figure 6) from James Heal according to SR EN ISO 4920/2013 (table 1). 


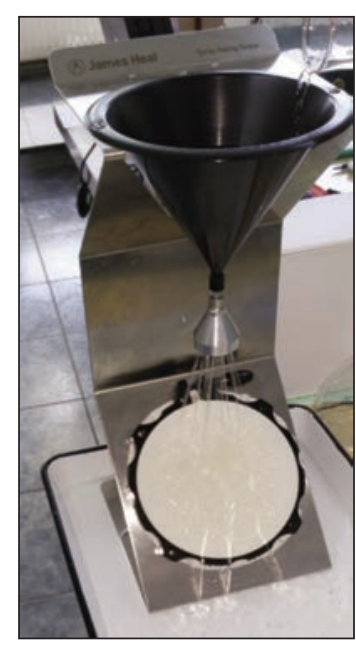

Fig. 6. Resistance to surface wetting tester James Heal
The morphological analysis was performed by using an electron scan microscope (SEM) with a view at $50 \mu \mathrm{m}$ scale with magnitude X8000 to highlight the morphological modifications (figure 7).

From all samples treated by RF plasma, the samples (M-etalon sample, P8, and P9 are samples coated by PTFE and Ar RF plasma technology) with the best values obtained to resistance to surface wetting test after 101 days, respective to water contact angle are presented in table 1.

$$
f(x)=a^{*} x^{4}+b^{*} x^{3}+c^{*} x^{2}+d^{*} x+e
$$

where: $x=P_{S F 6} ; f(x)=R_{S W} ; a=-26.82 ; b=3.213$; $c=89.43 ; d=-6.259 ; e=23.67$.

Besides, analyzing the covariations (cov) $\operatorname{cov}\left(R_{S W}\right.$ $\left.P_{S F 6}\right)(3)$ between resistance to surface wetting $\left(R_{S W}\right)$ and work pressure $\left(P_{S F 6}\right)$, respective $\operatorname{cov}\left(R_{S W}, \Phi_{S F 6}\right)$ (4) between $R_{S W}$ and gas flow rate $\left(\Phi_{S F 6}\right)$ we observed that resistance of surface wetting is in inverse proportionality report with both gas flow rate and gas pressure. That means that at the increasing of the values for pressure, respective floe rate, the resistance of surface wetting will have a decreasing trend.

$$
\begin{aligned}
& \operatorname{cov}\left(R_{S w^{\prime}}, P_{S F \sigma}\right)=\left|\begin{array}{ll}
0.0000 & -0.0011 \\
-0.0011 & 316.6667
\end{array}\right| \\
& \operatorname{cov}\left(R_{S w^{\prime}} \Phi_{S F \sigma}\right)=\left|\begin{array}{ll}
87.5000 & -85.0000 \\
-85.0000 & 316.6667
\end{array}\right|
\end{aligned}
$$

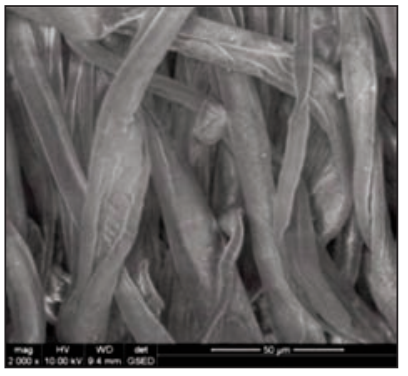

Etalon (M)

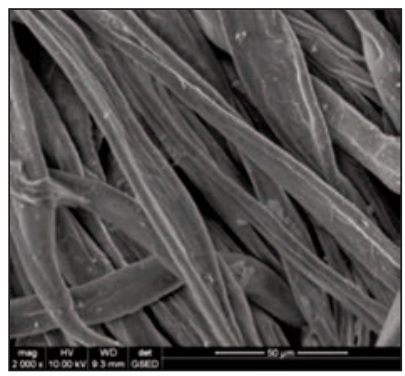

P6

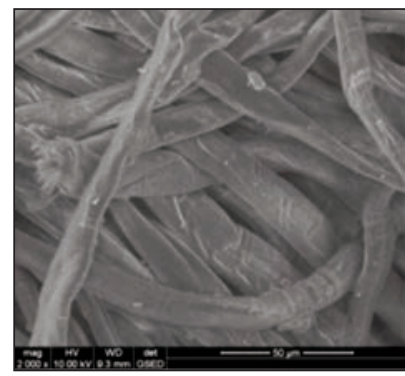

P8

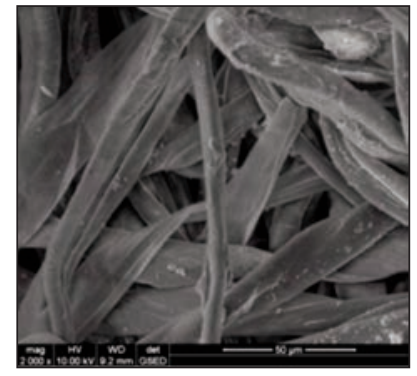

P9

Fig. 7. Morphological analysis for samples P6, P8, and P9 in comparison with the etalon

Table $1 \quad$ By analyzing data for samples treated

SAMPLE WITH HYDROPHOBIC CHARACTER OBTAINED IN

\begin{tabular}{|c|c|c|c|c|c|}
\hline \multirow{2}{*}{\multicolumn{2}{|c|}{ Tests }} & \multicolumn{3}{|c|}{ Results } & \multirow{2}{*}{ Standards } \\
\hline & & \multirow{2}{*}{$\frac{M}{0}$} & \multirow{2}{*}{$\begin{array}{c}\text { P8 } \\
2\end{array}$} & \multirow{2}{*}{$\begin{array}{l}\text { P9 } \\
2.5\end{array}$} & \\
\hline $\begin{array}{l}\text { Resistance } \\
\text { to surface }\end{array}$ & $\begin{array}{l}\text { Degree scale } \\
\text { ISO }\end{array}$ & & & & \multirow{2}{*}{$\begin{array}{l}\text { SR EN ISO } \\
4920 / 2013\end{array}$} \\
\hline $\begin{array}{l}\text { wetting } \\
\text { (Spray test) }\end{array}$ & $\begin{array}{l}\text { Photographic } \\
\text { scale AATCC }\end{array}$ & 0 & 70 & 75 & \\
\hline \multicolumn{2}{|c|}{ Contact angle } & $<1$ & 142.4 & 138.6 & ASTM D7490-08 \\
\hline
\end{tabular}
PLASMA AND PERSISTENT HYDROPHOBIC CHARACTER FOR APPROX. 100 DAYS with RF plasma Ar (Argon) and PTFE, we observed that these could not provide a bivariate linear analysis and a multivariate analysis of data (figure 10) was performed. Figure 10 presents the multivariate analysis graph for resistance to surface wetting (photographic scale AATCC) depending on gas volume $\left(V_{A r}\right)$ (5) during the experiment time $(t)$ and pressure $\left(P_{A r}\right)$.

$$
V_{A r}=\Phi_{A r}{ }^{*} t
$$

\section{BIVARIATE ANALYSIS OF THE EXPERIMENTAL DATA}

We used bivariate analysis (figures 8 and 9) of two variables (resistance to surface wetting reported to gas flow rate and pressure) to investigate the dependence or the difference between two variables.

By bivariate analysis the resistance to surface wetting $\left(R_{s w}\right)=f\left(\Phi_{S F 6}\right)$ resulted the linear model (1):

$$
f(x)=a^{*} x^{5}+b^{*} x^{4}+c^{*} x^{3}+d^{*} x^{2}+e^{*} x+f
$$

where: $x=\emptyset_{\mathrm{SF} 6} ; f(x)=R_{s w} ; a=-50.61 ; b=-14.04$; $c=128.9 ; d=40.65 ; e=-74.43 ; f=39.67$.

By bivariate analysis the resistance to surface wetting $\left(R_{s w}\right)=f\left(P_{S F G}\right)$ resulted the linear model (2):
By multivariate analysis of the parameters, the resistance to surface wetting $\left(R_{s w}=f\left(P_{A r}, V_{A r}\right)\right.$ resulted the linear model (6):

$$
f(x, y)=a+b^{*} x+c^{*} y+d^{*} x^{2}+e^{*} x^{*} y+f^{*} y^{2}
$$

where: $\quad R_{s w}=f(x, y) ; \quad x=V_{A r} ; \quad y=P_{A r} ; \quad a=66.15$; $b=-2.992 ; c=7.208 ; d=8.75 ; e=-2.059 ; f=-4.913$. By analyzing the covariations $\operatorname{cov}\left(R_{S W}, P_{A r}\right)$ (7) between resistance to surface wetting $\left(R_{S W}\right)$ and work pressure $\left(P_{A r}\right)$, respective $\operatorname{cov}\left(R_{S W}, V_{A r}\right)(8)$ between $R_{s w}$ and gas volume $\left(V_{A r}\right)$ we observed that resistance of surface wetting is in direct proportionality report with gas volume, respective gas pressure, but the most substantial influence has the gas volume inserted in plasma installation. 


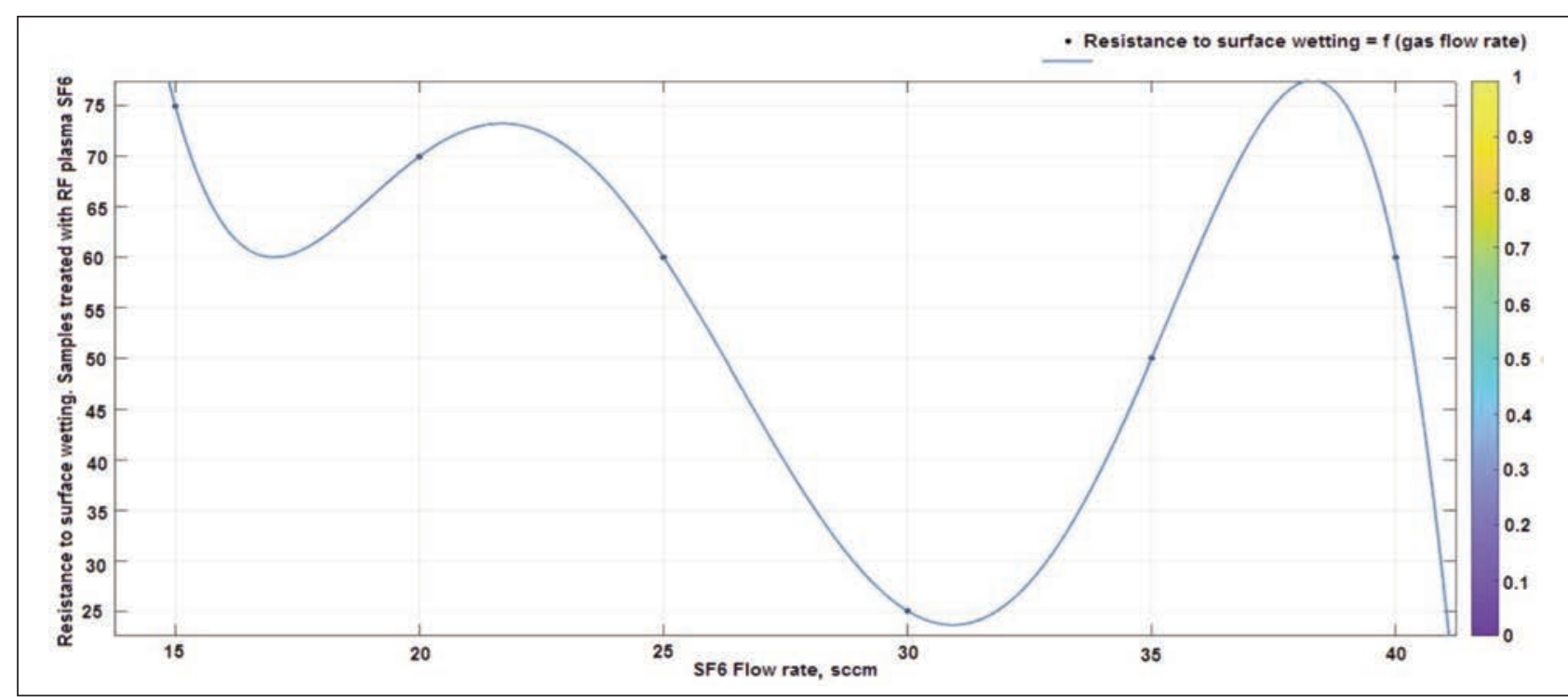

Fig. 8. Bivariate analysis $\rightarrow$ resistance to surface wetting $\left(R_{\text {sw }}\right)$ depending on the SF6 flow rate $\left(\Phi_{\text {SF } 6}\right)$-samples treated by $\mathrm{SF}_{6} \mathrm{RF}$ plasma

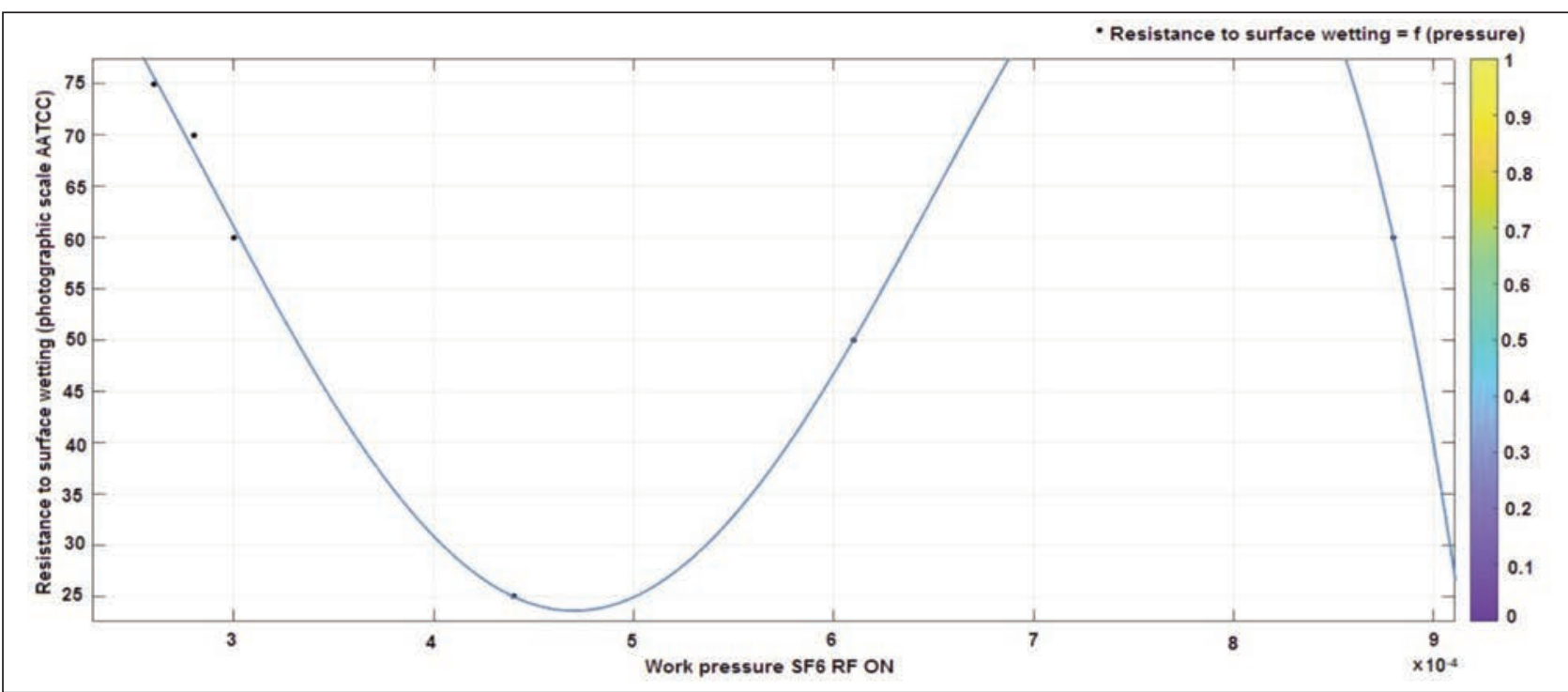

Fig. 9. Bivariate analysis $\rightarrow$ resistance to surface wetting $\left(R_{s w}\right)$ depending on the work pressure $\left(P_{S F 6}\right)$-samples treated by $\mathrm{SF}_{6} \mathrm{RF}$ plasma

$$
\begin{gathered}
\operatorname{cov}\left(R_{s w}, V_{A r}\right)=1.0 e+05 *\left|\begin{array}{cc}
2.2250 & 0.0225 \\
0.0225 & 0.0008
\end{array}\right| \\
\operatorname{cov}\left(R_{s w^{\prime}}, P_{A r}\right)=\left|\begin{array}{cc}
0.0000 & 0.0001 \\
0.0001 & 79.8611
\end{array}\right|
\end{gathered}
$$

\section{CONCLUSIONS}

The hydrophobic effect obtained by RF plasma technology has a temporary character (2-101 days) and has the advantages of reducing environmental waste and that it is a clean procedure. The substances used in plasma treatment are already reported harmful to human health. The resistance to surface wetting depends on the gas flow rate, time, and work pressure. In case of the samples treated by Ar RF plasma and PTFE was observed direct dependence between the resistance to surface wetting and the variations of gas volume, respective gas pressure used during the experiment. However, in the case of the samples treated with SF6 RF plasma it was observed an inverse dependence between the resistance of the surface wetting and the as flow rate or gas pressure variations during the experiment. Concerning the durability of the hydrophobization treatment it was observed that in case of the samples treated with SF6 the effect was temporary only for 24 hours, and after 48 hours was observed that samples become hydrophilic. Also, in case of the samples treated with Ar plasma and PTFE film deposition, the samples acquire a longtime hydrophobic effect, the last observations, after 101 days, indicating for two of the samples a remnant weak hydrophobic effect. In conclusion, the resistance to surface wetting and contact angle values are in a strong dependence, and the principal influence factors are time, drop speed, gas type, and temperature. 


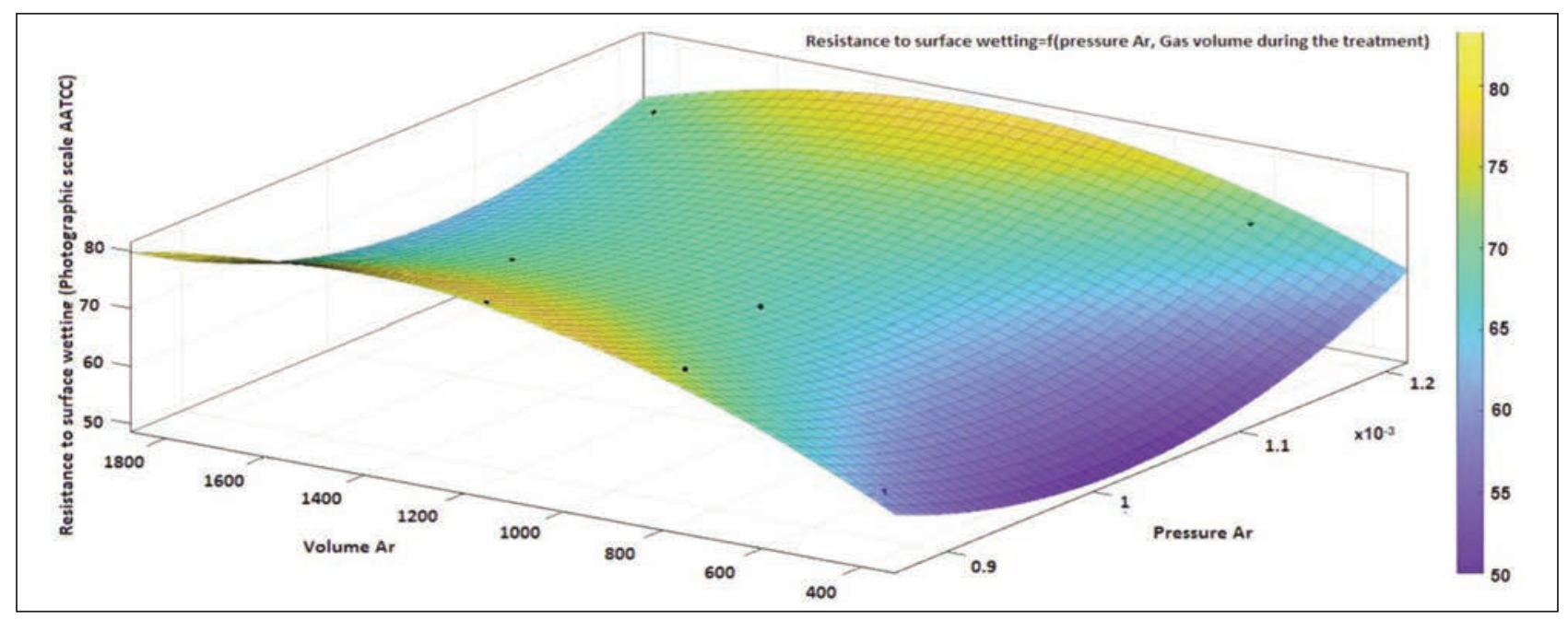

Fig. 10. 3D representation - resistance to surface wetting $\left(R_{s w}\right)$ related to the gas volume $\left(V_{A r}\right)$ and gas pressure $\left(P_{A r}\right)$

\section{ACKNOWLED GMENTS}

This research presented in this paper prepared in the INCDTP laboratories was funded by ANCSI, National Project "The assessment of the life cycle of the hydrophobic textile materials", Contract PN 16340407 . The treatments of the samples by SF6 RF plasma, Ar plasma, and PTFE deposition were performed by contract, using plasma equipment available at INFLPR.

\section{REFERENCES}

[1] Gulrajani, M.L., Deepti, G., Emerging techniques for functional finishing of textiles, 2011

[2] Vančo, M., Krmela, J., Pešlová, F., The use of PVD coating on natural textile fibers, In: Procedia Engineering, 2016, 136, 341-345

[3] Shahidi, S., Moazzenchi, B., Ghoranneviss, M., A review-application of physical vapor deposition (PVD) and related methods in the textile industry, In: The European Physical Journal Applied Physics, 2015, 71, 3, 31302

[4] Dubas, S.T., Kumlangdudsana, P., Potiyaraj, P., Layer-by-layer deposition of antimicrobial silver nanoparticles on textile fibers, In: Colloids and Surfaces A: Physicochemical and Engineering Aspects, 2006, 289, 1-3, 105-109

[5] Gashti, M.P., Alimohammadi, F., Shamei, A., Preparation of water-repellent cellulose fibers using a polycarboxylic acid/hydrophobic silica nanocomposite coating, In: Surface and Coatings Technology, 2012, 206, 14, 3208-3215

[6] Kabir, H., Matthess, J., Dietzel, Y., Offermann, P., Nocke, G., Matthess, K., PVD-coating for the processing of textiles, In: Research Journal of Textile and Apparel, 2004, 8, 1, 32-37

[7] Wei, Q., Xu, Y., Wang, Y., Textile surface functionalization by physical vapor deposition (PVD), In: Surface Modification of Textiles, 2009, ed Woodhead Publishing, 58-90

[8] Maity, S., Singha, K., Debnath, P., Singha, M., Textiles in electromagnetic radiation protection, In: Journal of Safety Engineering, 2013, 2, 2, 11-19

[9] Fu, K.K., Padbury, R., Toprakci, O., Dirican, M., Zhang, X., Conductive textiles, In Engineering of High-Performance Textiles, 2018 ed Woodhead Publishing, 305-334

[10] Kelly, P.J., Arnell, R.D., Magnetron sputtering: a review of recent developments and applications, In: Vacuum, 2000, 56, 3, 159-172

[11] Pierson, H. O., Handbook of chemical vapor deposition: principles, technology and applications, William Andrew, 1999

[12] Mattox, D. M., Handbook of physical vapor deposition (PVD) processing, William Andrew, 2010

[13] Seshan, K., Handbook of Thin Film Deposition, William Andrew, 2001

[14] Nee, A.Y.C., Handbook of manufacturing engineering and technology, Springer, 2015

[15] Lv, J., Zhou, Q., Zhi, T., Gao, D., Wang, C., Environmentally friendly surface modification of polyethylene terephthalate (PET) fabric by low-temperature oxygen plasma and carboxymethyl chitosan, In: Journal of cleaner production, 2016, 118, 187-196

[16] Shishoo, R. ed., Plasma technologies for textiles, Elsevier, 2007

[17] Romdhani, Z., Hamdaoui, M., Baffoun, A., Roudesli, S., General behavior and parameters affecting the Ink jet printing phenomenon on woven polyester fabric, In: Industria Textila, 2017, 68, 1, 37-46, https://doi.org/10.35530/IT.068.01.1327

[18] Haji, A., Shoushtari, A.M., Natural antibacterial finishing of wool fiber using plasma technology, In: Industria Textila, 2011, 62, 5, 244-247

[19] Haji, A., Qavamnia, S.S., Bizhaem, F. K., Optimization of oxygen plasma treatment to improve the dyeing of wool with grape leaves, In: Industria Textila, 2016, 67, 4, 244-249

\section{Authors:}

RALUCA MARIA AILENI, SILVIA ALBICI, LAURENTIU DINCA, LILIOARA SURDU

National Research \& Development Institute for Textiles and Leather,

Lucretiu Patrascanu no.16, 030508 Bucharest, Romania

\section{Corresponding author:}




\title{
Aspects concerning the mathematical distribution of metal microparticles on the textile surfaces with electroconductive properties obtained by printing method
}

\author{
DOI: 10.35530/IT.070.06.1605
}

\section{ABSTRACT - REZUMAT}

\section{Aspects concerning the mathematical distribution of metal microparticles on the textile surfaces with electroconductive properties obtained by printing method}

This paper presents the aspects concerning the mathematical distribution of metal microparticles on the textile surfaces to model the electroconductive properties of the textiles obtained by a printing method using electroconductive paste based on polyethylene glycol (PEG)/polyurethane (PU) and micro/nanoparticle (nickel, silver, and copper). A direct relationship between surface conductivity and surface $\mathrm{pH}$ and an inverse relation surface resistance and $\mathrm{pH}$ was observed. Besides this, in this paper, we analyzed the dependences between conductivity, $\mathrm{pH}$ and surface resistance by using covariance between two vectors $(\operatorname{cov}(p H, R s), \operatorname{cov}(C, p H), \operatorname{cov}(C, R s))$. The purpose of this research is to define a particles distribution that could be useful in establishing the correct distribution of the microparticles for obtaining the surface with antistatic/dissipative, and conductive properties for sensors or electromagnetic shields.

Keywords: textiles, electroconductive, plasma technology, microwave, printing, coating, padding

Astecte privind distribuţia matematică a microparticulelor de metal, cu proprietăţi electroconductive depuse pe suprafaţa textilă prin printare

Această lucrare prezintă aspecte referitoare la distribuția matematică a microparticulelor de metal pe suprafața textilă, în scopul modelării proprietăților electroconductive obținute prin metoda printării pastei conductive pe bază de polietilenglicol (PEG)/poliuretan (PU) şi micro/nanoparticule (nichel, argint şi cupru). S-a observat o dependență directă între conductivitatea suprafeței şi pH şi o relație de dependență inversă între rezistența de suprafață şi pH. În plus, în această lucrare s-au analizat dependențele dintre conductivitate, $\mathrm{pH}$ şi rezistența de suprafață, prin intermediul covariaței între doi vectori $(\operatorname{cov}(p H, R s), \operatorname{cov}(C, p H), \operatorname{cov}(C, R s))$. Scopul acestei cercetări a fost de a defini distribuția particulelor, care ar putea fi utilă în stabilirea unei distribuții corecte a microparticulelor în scopul obținerii de suprafețe cu proprietăți antistatice/disipative şi conductive, pentru senzori sau ecrane de protecție electromagnetică.

Cuvinte-cheie: materiale textile, electroconductiv, tehnologia plasmei, microunde, printare, fulardare

\section{INTRODUCTION}

The functionalization of the fabrics is based on pretreatments by microwave [1-3] or RF plasma [4-6], followed by treatment for the submission of micro/ nanoparticles dispersion/paste by padding method (foulard) [7], thin film deposition or direct printing [8-9]. Also, another approach consists of using RF plasma technology to improve the electrical conductivity of the fabric by carbon nanotubes functionalization on poly(ethylene terephthalate) [10-11]. The content of micro/nanoparticule of solution/paste influence finally the electroconductive properties of the surface. Thus, increasing the content of micro/nanoparticles can lead to the effect of the electroconductive surface, when using a low content of micro/nano.

The padding method [7] consists of immersing the textile material in solution or dispersion and squeezing between the drive cylinders and squeezing. By immersion of the textile in dispersion based on metal micro/nanoparticles the distribution of the micro/ nanoparticles will be on both sides of the material, by one or more than one pass. These metal micro/ nanoparticles can lead to antistatic or dissipative effects. Another method used to improve the electrical conductivity of the composite materials consists of mixing sol-gel method and padding technique using organo-silicon sol with graphene particles [12] or using a "dip and dry" method for textile coating with graphene oxide [13]. Besides, it can be used coating polyester fabric with polypyrrole and doped with graphene oxide [14] in order to obtain conductive polyester fabric.

Fabric coating [15], also named knife coating [16] or doctor blade [17-18], means the application of one or more thin-films using a knife moving over blanket [18]. Based on this method, the thin-film can be applied on one side or both sides of the textile product.

For the submission of micro/nanoparticle by printing [19] using polymeric pasta containing metals (particle 
size nano and micro) a metallic or PES screen is used. The method of printing conductive material is the fastest finishing method with low energy consumption and costs. The most used techniques of print are printing on the rotary film, printing on flat film and thermal transfer printing.

To reduce the wastewater and carbon footprint can be used RF plasma oxygen or argon to improve the hydrophily of the fabric and the deposition of the metallic micro/nanoparticles using padding, coating, or screen printing [20].

\section{EXPERIMENTAL PART}

To obtain the textile models functionalized by submission of nano/microparticles there were used standard technologies such as padding method, coating and printing, and advanced technology (microwave) for textile drying and polymer cross-linking. To obtain the electroconductive properties there were used several polymers, such as polyurethane (PU), polyethylene glycol (PEG), and polyvinyl alcohol (PVA) with the content of silver (Ag) micro/nanoparticles.

In our experiment based on the padding method, we used dispersions based on polyethylene glycol (PEG) with Ag nanoparticles (<150 nm), copper (Cu) microparticles $(14-75 \mu \mathrm{m})$ and nickel $(\mathrm{Ni})(<50 \mu \mathrm{m})$. These samples with different compositions of the metal micro/nanoparticle have been determined the conductivity and $\mathrm{pH}$ of the solution (1).

Also, in the laboratory it was tested the surface resistance of the ratio of the direct voltage applied between the two parallel electrodes on the surface of a test-pieces and the current between these electrodes, neglecting any phenomena of polarization of the electrodes, as described in table 1.

$$
C=G^{*} k
$$

where:

$\mathrm{C}$ is the conductivity of the paste $[\mu S]$;

$\mathrm{G}$ - the conductance of the paste [S];

$k$ - the constant of the sensor, $k=0.1 \mathrm{~cm}^{-1}$

For thin-film deposition a laboratory coating device type SV was used. Using the coating method for deposition of the thin-films based on polyurethane (PU) and alcohol polyvinyl (PVA), with $\mathrm{Ag}_{1}$ microparticles (2-3.5 $\mu \mathrm{m}), \mathrm{Ag}_{2}(<45 \mu \mathrm{m}), \mathrm{Ni}(<50 \mu \mathrm{m}), \mathrm{Cu}(14-75$ $\mu \mathrm{m})$ and graphite $(\mathrm{C})$ there were obtained the textile surface functionalized according to table 2 .

For experimental models obtained by the coating method based on microparticle (figure 1) the resistance of the surface has been measured using the appliance PROSTAT PRS 801 [21] (figure 2) and values in the range of values specific to conductive

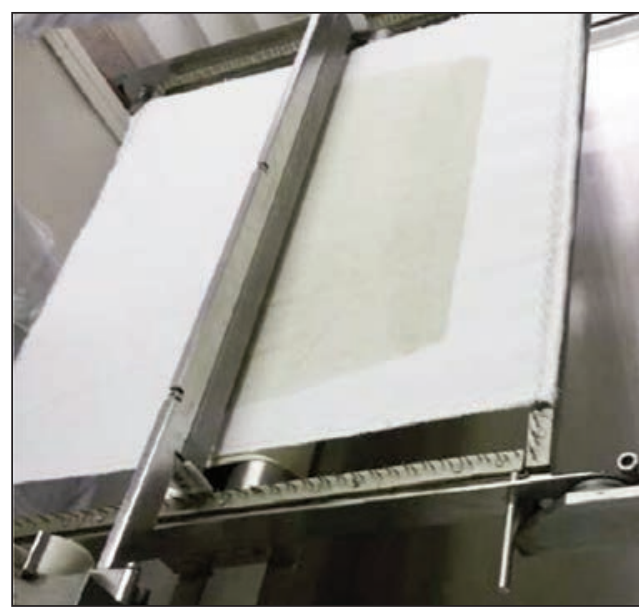

Fig. 1. Thin-film based on metal microparticle deposition using laboratory coating device type SV

Table 1

\begin{tabular}{|c|c|c|c|c|c|c|c|c|c|}
\hline \multicolumn{10}{|c|}{} \\
\hline Sample & Ag & Ni & Cu & PEG & Ethanol & $\mathbf{H}_{2} \mathbf{O}$ & $\begin{array}{c}\text { Conductivity C } \\
(\mu S)\end{array}$ & pH & $\begin{array}{c}\text { Surface resistance Rs } \\
(\Omega)\end{array}$ \\
\hline 1 & & & $\mathrm{x}$ & $\mathrm{x}$ & & $\mathrm{x}$ & 155 & 5.9 & $1.3 \times 10^{10}$ \\
\hline 2 & $\mathrm{x}$ & & & $\mathrm{x}$ & & $\mathrm{x}$ & 191 & 7.5 & $1.2 \times 10^{9}$ \\
\hline 3 & & $\mathrm{x}$ & & $\mathrm{x}$ & & $\mathrm{x}$ & 268 & 7.1 & $1.1 \times 10^{9}$ \\
\hline 4 & & & $\mathrm{x}$ & $\mathrm{x}$ & $\mathrm{x}$ & $\mathrm{x}$ & 129 & 5.4 & $1.4 \times 10^{11}$ \\
\hline 5 & $\mathrm{x}$ & $\mathrm{x}$ & $\mathrm{x}$ & $\mathrm{x}$ & $\mathrm{x}$ & $\mathrm{x}$ & 164 & 5.7 & $1.2 \times 10^{10}$ \\
\hline
\end{tabular}

\begin{tabular}{|c|c|c|c|c|c|c|c|c|c|}
\hline \multicolumn{10}{|c|}{ TEXTILE SURFACE WITH THIN-FILM DEPOSITED } \\
\hline Sample & $\mathbf{A g}_{1}$ & $\mathbf{A g}_{2}$ & $\mathbf{C u}$ & $\mathbf{N i}$ & $\mathrm{PU}$ & PVA & $\mathbf{C}$ & $\begin{array}{c}\text { Synthetic } \\
\text { thickening agent }\end{array}$ & $\begin{array}{c}\text { Surface resistance Rs } \\
(\Omega)^{*}\end{array}$ \\
\hline 1 & $\mathrm{x}$ & $\mathrm{x}$ & & & $\mathrm{x}$ & $\mathrm{x}$ & & $\mathrm{x}$ & $2.3 \times 10^{1} \div 6.6 \times 10^{5}$ \\
\hline 2 & & & $\mathrm{x}$ & & & $\mathrm{x}$ & $\mathrm{x}$ & $\mathrm{x}$ & $2.0 \times 10^{10} \div 4.0 \times 10^{12}$ \\
\hline 3 & $\mathrm{x}$ & & & & & $\mathrm{x}$ & $\mathrm{x}$ & $\mathrm{x}$ & $1.9 \times 10^{10} \div 3.1 \times 10^{12}$ \\
\hline 4 & $\mathrm{x}$ & $\mathrm{x}$ & & $\mathrm{x}$ & & $\mathrm{x}$ & & $\mathrm{x}$ & $2.9 \times 10^{12} \div 5.9 \times 10^{12}$ \\
\hline
\end{tabular}

* Minimum and maximum limits of the resistance values of the surface obtained by individual measurements 


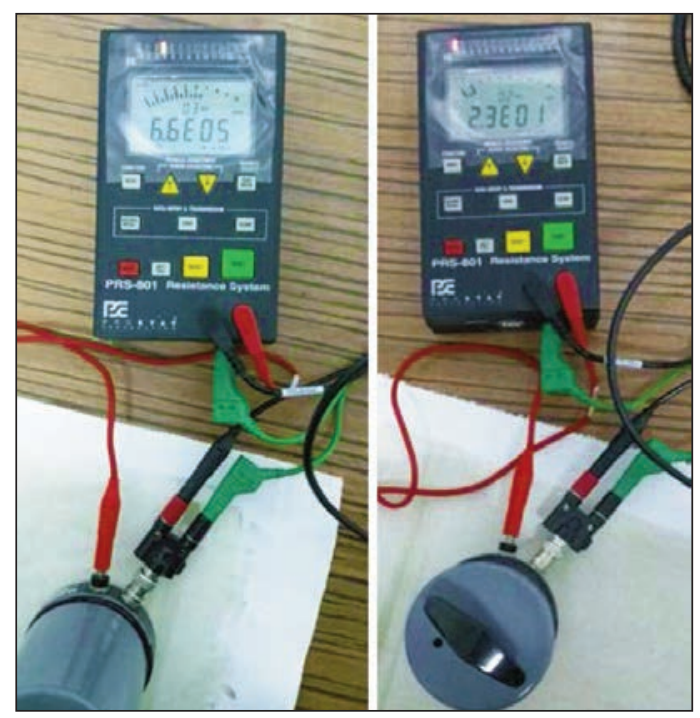

Fig. 2. Surface resistance measurement for sample coated

materials $\left(10^{2}-10^{5}\right)$ were obtained. In addition, for these samples the main physico-mechanical characteristics that are presented in table 3 have been evaluated.

Table 3

\begin{tabular}{|c|c|c|c|c|}
\hline \multicolumn{5}{|c|}{ PHYSICO-MECHANICAL CHARACTERISTICS FOR } \\
SAMPLE NO. 1 \\
\hline Sample & $\begin{array}{c}\text { Mass } \\
{\left[\mathbf{g} / \mathbf{m}^{2}\right]}\end{array}$ & $\begin{array}{c}\text { Thickness } \\
{[\mathrm{mm}]}\end{array}$ & $\begin{array}{c}\text { Air } \\
\text { permeability } \\
\left(1 / \mathbf{m}^{2} / \mathbf{s e c}\right)\end{array}$ & $\begin{array}{c}\text { Surface } \\
\text { resistance } \\
\text { Rs }(\Omega)^{*}\end{array}$ \\
\hline 1 & 596.5 & 0.821 & 16.28 & $\begin{array}{c}2.3 \times 10^{1} \div \\
6.6 \times 10^{5}\end{array}$ \\
\hline
\end{tabular}

* Minimum and maximum limits of the resistance values of the surface obtained by individual measurements

Also, it was used the morphological analysis by electron microscopy in order to present the surface of the before metal particles deposition (figure 3 ) and after metal nano/microparticles deposition (figure $3, b$ ).

Using printing technology, with paste containing $\mathrm{Cu}$ microparticles $(14-75 \mu \mathrm{m}), \mathrm{Ni}(<50 \mu \mathrm{m}), \mathrm{Ag}(2-45$ $\mu \mathrm{m}$ graphite), graphite (C), PVA (polyvinyl alcohol) and synthetic thickener, samples have been carried out following table 4.

Controlled drying of the samples (30 seconds1 minute) has been carried out in the field of the

Table 4

FUNCTIONALISED SAMPLES BY MICROPARTICLE SUBMISSION USING PRINTING METHOD

\begin{tabular}{|c|c|c|c|c|c|c|}
\hline Sample & Cu & Ni & Ag & PVA & C & $\begin{array}{c}\text { Thickening } \\
\text { agent }\end{array}$ \\
\hline M1 & & & & $x$ & $x$ & $x$ \\
\hline M2 & $\mathrm{x}$ & & $\mathrm{x}$ & $\mathrm{x}$ & $\mathrm{x}$ & $\mathrm{x}$ \\
\hline M3 & $\mathrm{x}$ & & & $\mathrm{x}$ & $\mathrm{x}$ & $\mathrm{x}$ \\
\hline M4 & & $\mathrm{x}$ & & $\mathrm{x}$ & $\mathrm{x}$ & $\mathrm{x}$ \\
\hline M5 & & & $\mathrm{x}$ & $\mathrm{x}$ & $\mathrm{x}$ & $\mathrm{x}$ \\
\hline
\end{tabular}

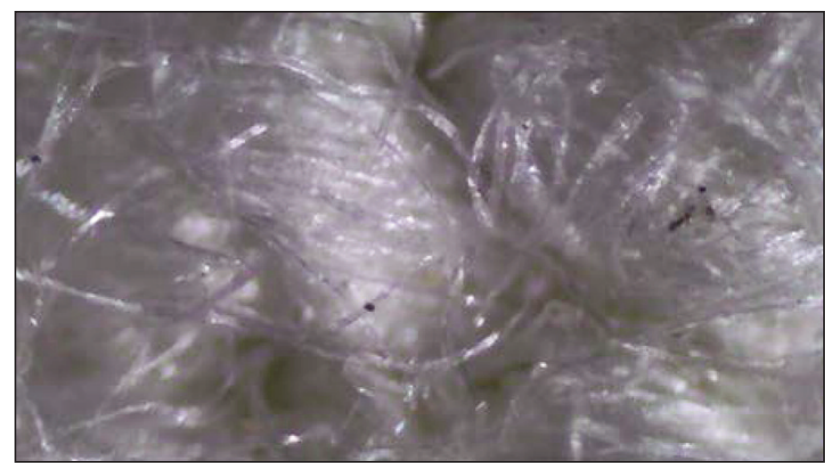

a

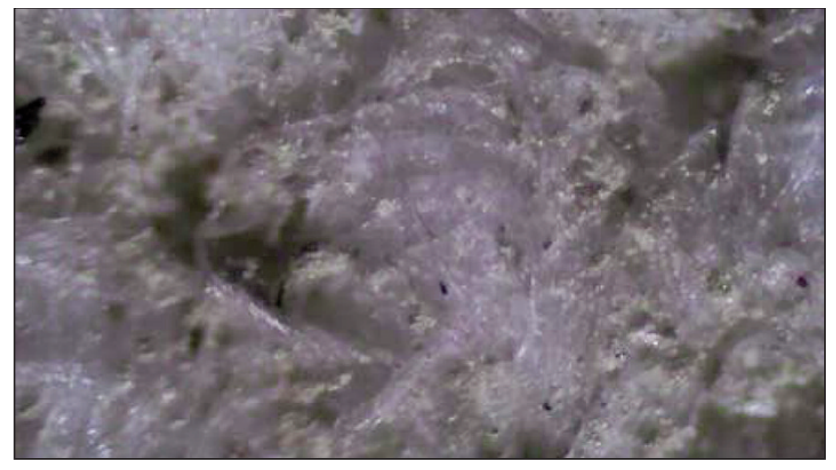

b

Fig. 3. Textile sample analysis based on electron microscopy: a - initial textile sample;

$b$ - textile surface coated with a thin film

microwave power generated by a high voltage generator (magnetron) which converts the current continuously into radiofrequency energy (frequency 2.4 $\mathrm{GHz}$, power $700 \mathrm{~W}$ ).

\section{RESULTS AND DISCUSSIONS}

In figure 4 is presented the representation of the 3D surface resistance of the samples obtained by padding method in the function of the $\mathrm{pH}$ and dispersion conductivity using Matlab software and multivariate analysis of the surface resistance (Rs) in the function of the dispersion conductivity (C) and $\mathrm{pH}$.

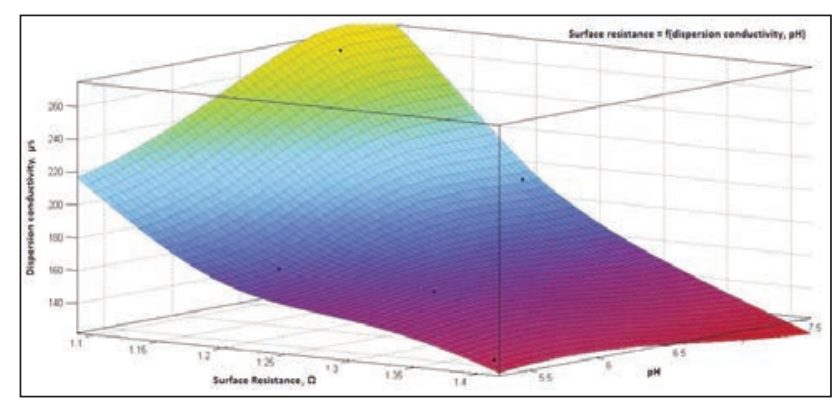

Fig. 4. 3D representation of the surface resistance according to the $\mathrm{pH}$ and dispersion conductivity $(R s=f(C, p H))$

Based on analysis of the covariation between $p H$, the surface resistance $\left(R_{S}\right)$ and the dispersion electroconductivity $(C)(2,3,4)$ it was demonstrated that between the surface resistance and $\mathrm{pH}$ it is an inverse proportionality, and between the $\mathrm{pH}$ and dispersion conductivity it is a direct proportionality. 


$$
\begin{gathered}
\operatorname{cov}(p H, R s)=\left|\begin{array}{cc}
0.8520 & -0.0760 \\
-0.0760 & 0.0130
\end{array}\right| \\
\operatorname{cov}(C, p H)=1.0 e+03 *\left|\begin{array}{cc}
0.8343 & 0.0372 \\
0.0372 & 0.0009
\end{array}\right| \\
\operatorname{cov}(C, R s)=1.0 e+03 *\left|\begin{array}{cc}
2.8343 & -0.0054 \\
-0.0054 & 0.0000
\end{array}\right|
\end{gathered}
$$

For the assessment of the electromagnetic shielding effectiveness $\left(S E_{d B}\right)$ the fabrics have been cut in the shape with an outer diameter of $100 \mathrm{~mm}$ and an inner diameter of $30 \mathrm{~mm}$ to be able to be fitted inside the measuring cell used. After they have been cut, on the edges of the samples has been coated with conductive paint based on the silver to ensure a suitable electrical contact with the measuring cell. The tests have to be performed at a temperature of $22^{\circ} \mathrm{C}$ and humidity $40 \%$. For the investigation of the electromagnetic shielding attenuation [22-23], we have used the following specific equipment (of the equipping INCD-ICPE-CA): coaxial cell model TEM 2000 (figure 5); oscilloscope Tektronix MDO model 3102; power amplifier Model SMX5; signal generator type E8257D. To evaluate the electromagnetic shielding efficiency the Schelkunoff equation (5) it was used:

$$
S B_{d B}=10 \log _{10} \frac{P_{1}}{P_{2}}
$$

where:

$P_{1}[\mathrm{~dB}]$ is the power of the signal detected in the absence of the electromagnetic screen;

$P_{2}[\mathrm{~dB}]$ - the power of the signal detected in the presence of the electromagnetic screen.

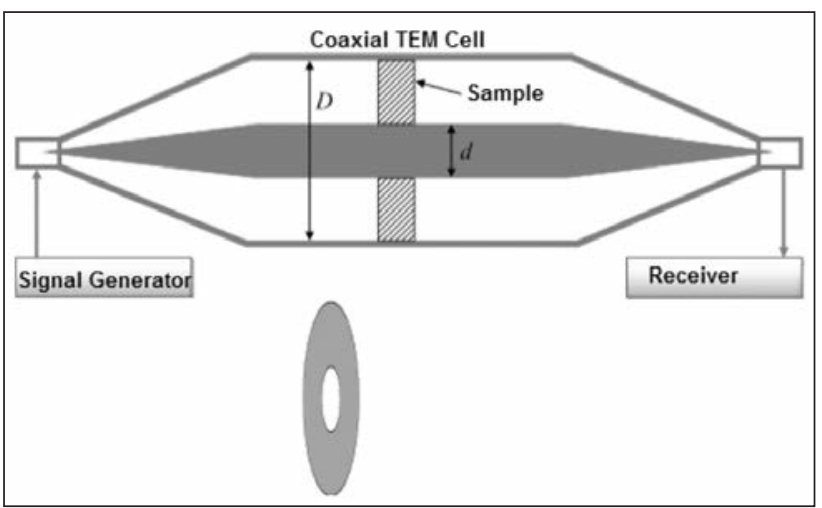

Fig. 5. Schematic representation of the sample and coaxial measuring cell TEM 2000

$S E_{d B}$ represents the difference between the measured signal without the sample and the signal level measured with the sample mounted inside the cell, and both measured in $\mathrm{dB}$ (according to the standard IEEE Std 299-2006). The tests were based on the following standards: ASTM D4935-89, ASTHMA ES783, IEEE Std 299-2006. The electromagnetic shielding effectiveness depending on the frequency in the field $0.3 \mathrm{MHz}-1 \mathrm{GHz}$ is presented in figure 6. During the investigation for electromagnetic shielding, only the samples M4 and M5 have proved useful.

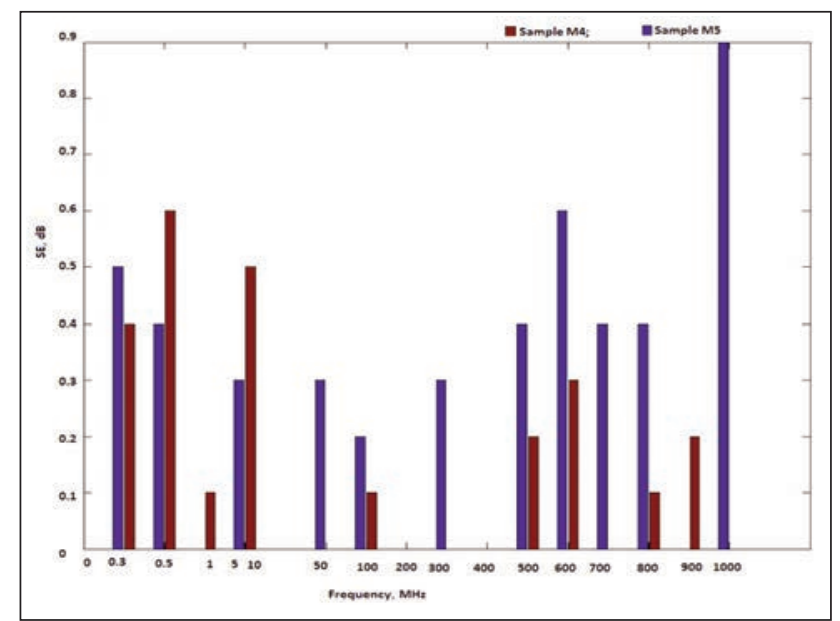

Fig. 6. 2D representation of the electromagnetic efficiency attenuation vs. frequency

\section{CONCLUSIONS}

As a result of the evaluation of the results (experimental models) the textiles with electroconductive properties can be classified as a conductive, antistatic, or EM shields.

The experimental models obtained by padding method with dispersions based on Ni microparticles in polyethylene glycol, have the best antistatic properties because the resistances of the surface for the samples are within the range of $10^{9}$ to $10^{10}$. It can be concluded that the experimental models obtained by the padding method have the surface resistance within the range specific to the materials with antistatic properties $\left(1.0 \times 10^{5}-1.0 \times 10^{12}\right)$.

The experimental models obtained by printing based on polimeric solutions (alcohol polyvinyl and polyurethane) with graphite and $\mathrm{Ni}$ microparticles content present the best value for the electromagnetic shielding effectiveness $\left(S E_{d B}\right)$.

The experimental models made by thin film deposition based on silver microparticles dispersed in the polymer such as polyurethane (PU) and alcohol polyvinyl (PVA), show the lowest values for resistance $\left(2.3 \times 10^{1}-6.6 \times 10^{5}\right)$ and the most significant default values for the electrical conductivity having the potential for use for the constituents of the sensors. In conclusion, the increase in the $\mathrm{pH}$ value or the amount of conductive microparticles particle causes an increase in conductivity of the solution, which leads by default to obtain conductive surfaces with low surface resistivity. The surface resistance variation for the same sample can be explained by the fact that the distribution of the nano/microparticle in pastes used for printing/coating or in the dispersions used for padding method is not uniform.

\section{ACKNOWLEDGMENTS}

The research presented in this paper was prepared in the INCDTP laboratories. Funds support this work from $\mathrm{MCl}$, National Project "Optimizing the performance of the functional textile by advanced technologies", Contract PN 1823 0105 . The evaluation of the electromagnetic shielding effectiveness has been performed by using the equipment available in INCD-ICPE-CA, Contract 2048/11.2018. 


\section{REFERENCES}

[1] Katović, D., Microwaves in Textile Finishing Yes or No, In: Journal of Textile Scence \& Engineering, 2011, 1, 1, 1-5

[2] Haggag, K., Ragheb, A., Nassar, S.H., Hashem, M., El Sayed, H., Abd El - Thalouth, I., Microwave Irradiation and its Application in Textile Industries, In: Science Publishing Group, 2014

[3] Hudson, Rolow, A., Microwave sanitization of textile, MASTER' THESIS, Kansas State University, 1977

[4] Zille, A., Oliveira, F.R., Souto, A.P., Plasma treatment in textile industry, In: Plasma processes and Polymers, 2015, 12, 2, 98-131

[5] Hossain, M.M., Herrmann, A.S, Hegemann, D., Plasma hydrophilization effect on different textile structures, In: Plasma Processes and Polymers, 2006, 3, 3, 299-307

[6] Hegemann, D., Plasma polymerization and its applications in textiles, 2006

[7] Veugelers, W.J., Woerlee, G.F., Gooijer, H., Gerritsen, J.W., Stork Prints, B.V., Method for dyeing textile materials in a supercritical fluid, 2003, U.S. Patent 6, 620, 211

[8] Kara, S., Yesilpinar, S., Senol, Y., Akkan, T., Design of an electronically equipped sailing garment for improved safety, In: Industria Textila, 2017, 68, 1, 23-30, https://doi.org/10.35530/IT.068.01.1319

[9] Dumitrescu, I., Nello, L.P., Iordache, O.G., Bima, G., The influence of the textile materials structure on the screen printed circuits' characteristics, In: Industria Textila, 2014, 65, 6, 310-317

[10] Haji, A., Rahbar, R.S., Shoushtari, A.M., Plasma assisted attachment of functionalized carbon nanotubes on poly (ethylene terephthalate) fabric to improve the electrical conductivity, In: Polimery, 60(5), 2015, 337-342

[11] Haji, A., Rahbar, R.S., Shoushtari, A.M., Improved microwave shielding behavior of carbon nanotube-coated PET fabric using plasma technology, In: Applied Surface Science, 311, 2014, 593-601

[12] Kowalczyk, D., Brzezinski, S., Kaminska, I., Wrobel, S., Mizerska, U., Fortuniak, W., Piorkowska, E., Svyntkivska, M., Makowski, T., Electrically conductive composite textiles modified with graphene using sol-gel method, In: Journal of Alloys and Compounds, 784, 2019, 22-28

[13] Shateri-Khalilabad, M., Yazdanshenas, M.E., Fabricating electroconductive cotton textiles using graphene, Carbohydrate polymers, 96(1), 2013, 190-195

[14] Molina, J., Zille, A., Fernández, J., Souto, A.P., Bonastre, J., Cases, F., Conducting fabrics of polyester coated with polypyrrole and doped with graphene oxide, In: Synthetic Metals, 204, 2015, 110-121

[15] Singha, K., A review on coating \& lamination in textiles: processes and applications, In: American Journal of Polymer Science, 2012, 2, 3, 39-49

[16] Liu, S., Deng, F., DuPont Teijin Films US LP, Film coating composition and method, U.S. Patent Application 2019, $16 / 256,297$

[17] Conway, R., Coating of textiles, In: Handbook of Technical Textiles, ed. Woodhead Publishing, 2016, 211-229

[18] Sen, A.K., Coated Textiles Principles and Applications, Technomic Pub. Co. Inc, Lancaster, Pa, 2001

[19] Gehrke, I., Tenner, V., Lutz, V., Schmelzeisen, D., Gries, T., Smart Textiles Production: Overview of Materials, In: Sensor and Production Technologies for Industrial Smart Textiles, 2019, MDPI

[20] Aileni, R.M., Chiriac, L., Radulescu, R.I., Surdu, L., Life cycle assessment of the electroconductive textiles functionalized by advanced technologies (plasma) and metallic micro/nanoparticles deposition, Industria Textila, 70(3), 2019, 205-210

[21] User Manual Prostat PRS Meter 801, [online] Available at: http://www.prostatcorp.com/files/manuals/en-us/ prs801manual_en.pdf [Accessed 6 August 2018]

[22] Ceven, E.K., Karaküçük, A., Dirik, A.E., Yalçin, U., Evaluation of electromagnetic shielding effectiveness of fabrics produced from yarns containing metal wire with a mobile based measurement system, In: Industria Textila, 2017, 68, 4, 289-295, https://doi.org/ 10.35530/IT.068.04.1372

[23] Turksoy, H.G., Bilgin, S., Electromagnetic shielding effectiveness of spacer knitted hybrid fabrics, In: Industria Textila, 2016, 67, 5, 297-301

\section{Authors:}

RALUCA MARIA AILENI, LAURA CHIRIAC, ELENA PERDUM, ELENA CORNELIA MITRAN, LILIOARA SURDU

National Research \& Development Institute for Textiles and Leather Lucretiu Patrascanu no.16, 030508 Bucharest, Romania

\section{Corresponding author:}

RALUCA MARIA AILENI

e-mail: raluca.aileni@incdtp.ro 


\title{
Predicting the fabric width of single jersey cotton knitted fabric using appropriate software
}

\author{
DOI: 10.35530/IT.070.06.1597
}

\section{ABSTRACT - REZUMAT}

\section{Predicting the fabric width of single jersey cotton knitted fabric using appropriate software}

Prediction of any property of the material has attracted the attention of many scientists all over the world in order to produce better products. Information Technology (IT) field has many applications and plays dominant role in the production of various products in the industry. Knitted fabric should satisfy a number of requirements of consumer. Fabric width is a very important property which affects knitted fabric comfort properties. The deviation from the fabric width will either lead to more consumption of raw material or affect profit of the company. Hence, controlling the width of the fabric has an adverse effect on company's profit and usage of raw materials. An investigation of the prediction of the width of the single jersey cotton knitted fabric in a fully relaxed state using Data mining technique in Rough set Computational based Priority Prediction Model (RCPPM) is reported. The inputs were yarn count, machine diameter, required GSM, machine gauge, actual yarn count, lea weight, lea strength, twist multiplier, loop length, course per $\mathrm{cm}$, wales per $\mathrm{cm}$, length shrinkage, width shrinkage, and fabric width. The real-time textile dataset consisted of 7,505 single jersey cotton knitted fabric samples. The results showed that the fabric width obtained by using aforesaid model was found to yield very accurate values and compared favourably with the measured ones. This study will lead to the production of the knitted fabric with better comfort and dimensional stability.

Keywords: data mining, dimensional stability, IT, prediction model, rough set, textile dataset

\section{Proiectarea lățimii tricotului glat din bumbac utilizând software-ul adecvat}

Predicția oricărei proprietăți a materialului a atras atenția multor oameni de știință din întreaga lume pentru a obţine produse performante. Domeniul Tehnologiei Informației (IT) are multe aplicații și joacă un rol dominant în fabricarea de produse diverse din industrie. Materialul tricotat ar trebui să satisfacă o serie de cerințe ale consumatorului. Lățimea tricotului este o proprietate foarte importantă, care influenţează proprietățile de confort. Abaterea de la lățimea tricotului va conduce fie la un consum mai mare de materie primă, fie va afecta profitul companiei. Prin urmare, controlul lățimii tricotului are efect negativ asupra profitului și utilizării materiei prime ale companiei. Este studiată predicţia lățimii tricotului glat din bumbac într-o stare complet relaxată, folosind tehnica de extragere a datelor în Modelul de predicție cu prioritate bazat pe calcul aproximativ (RCPPM). Intrările au fost reprezentate de finețea firului, diametrul mașinii, GSM-ul necesar, fineţea mașinii, finețea reală a firului, masa, rezistența la tracţiune, multiplicatorul de torsiune, lungimea buclei, rânduri per cm, șiruri de ochiuri per cm, contracția lungimii, contracția lățimii și lățimea tricotului. Setul de date real a constat din 7.505 de probe de tricot glat din bumbac. Rezultatele au arătat că lățimea tricoturilor obținute prin utilizarea modelului menționat anterior a înregistrat valori foarte precise și comparabile cu cele măsurate. Acest studiu va duce la producerea de tricoturi cu proprităţi îmbunătăţite de confort și stabilitate dimensională.

Cuvinte-cheie: extragerea datelor, stabilitate dimnesională, IT, model de predicție, set aproximativ, set de date

\section{INTRODUCTION}

It is very important to take into account the optimum width of the knitted fabric for tailoring purposes. Changes in fabric width will have an adverse effect on the comfort properties of fabrics and spoil the reputation of the company that manufactures them. The software for predicting fibre areal density was developed by Gravas et al. [1]. Panda et al. [2] dealt with the prediction of fabric width of single jersey cotton knitted fabrics by an artificial neural network. A number of publications on soft computing, data mining techniques and others are available [3-12]. Kalkanci et al. [13] have predicted the dimensional change in finished fabric through an artificial neural network. The usefulness of the Starfish technique has been pointed out by Hossain et al. [14]. The fabric width is calculated for single jersey cotton knitted fabric using the following formulae [15]

$$
\begin{aligned}
& \text { Fabric width }(\mathrm{cm})= \\
& \quad=\text { number of needles * wale spacing }
\end{aligned}
$$

Fabric width $(\mathrm{cm})=$ course length $/ K_{w}$, where course length $=n$ *I ( $n$ - number of needles, $I-$ loop length in $\mathrm{cm}, K_{w}-$ fabric dimensional constant)

$$
\begin{aligned}
& \text { Fabric width }(\mathrm{cm})= \\
& \quad=\text { number of needles * yarn diameter }(\mathrm{cm}) * 4
\end{aligned}
$$

This paper is concerned with the prediction of fabric width using new approaches such as rough set and data mining technique which have not been exploited by previous research workers. 


\section{EXPERIMENTAL}

For this study, extensive data were collected from Tirupur knitting units. From those data, we have taken 7,505 fabric sample values of dataset. The summary of the dataset is given in table 1. It should be mentioned that all the fabric samples considered are plain jersey, jet dyed and made of $40^{\mathrm{s}}$ (15 Tex) carded cotton yarns in a ring frame. They were fully relaxed as per the Starfish recommendations. Out of 7,505 fabric sample values of dataset, one group consisted of 6,432 fabric sample values of dataset using for the software learning (training purpose) and another group consisted of 1,073 fabric sample values of dataset for testing purposes. A list of parameters used for training and for testing is given in tables 2 and 3 .
Rough Computational based Priority Prediction Model (RCPPM)

Data science is a process used to discover hidden patterns from a large amount of data using statistical and machine learning approaches. Data science classification techniques are used in a number of applications like customer analytics, marketing analytics, water quality analytics, healthcare analytics, textile production analytics, manufacturing analytics and textile waste analytics. The proposed idea is to predict the fabric width based on the various parameters of textile data using rough computational based priority prediction model (RCPPM). A novel Gaussian Bayesian method is one of the important data science classification methods which are used to develop the proposed prediction model. Figure 1 shows the architecture of the proposed framework.

SUMMARY OF PARAMETERS OF ENTIRE DATASET (FOR 7,505 FABRIC SAMPLES)

\begin{tabular}{|l|c|c|c|c|}
\hline \multicolumn{1}{|c|}{ Parameters } & Mean & $\begin{array}{c}\text { Standard } \\
\text { deviation }\end{array}$ & $\begin{array}{c}\text { Maximum } \\
\text { value }\end{array}$ & $\begin{array}{c}\text { Minimum } \\
\text { value }\end{array}$ \\
\hline Nominal linear density (tex) & 14.76 & - & 14.76 & 14.76 \\
\hline Actual linear density (tex) & 15.32 & 0.33 & 17 & 1.55 \\
\hline Lea weight (gms) & 1.68 & 0.04 & 1.87 & 33.68 \\
\hline Lea strength (lbs) & 57.29 & 8.27 & 78.49 & 0 (due to missing values) \\
\hline Twist multiplier (tpcm* tex ${ }^{0.5}$ ) & 35.10 & 0.38 & 36.98 & 21.67 \\
\hline Loop length (mm) & 2.18 & 0.05 & 2.42 & 16.48 \\
\hline Course per cm & 24.98 & 0.72 & 27.98 & 357.22 \\
\hline Wales per cm & 18.31 & 0.39 & 19.88 & 0.02 \\
\hline Stitch density (cm ${ }^{2}$ ) & 457.71 & 23.05 & 556.30 & 1.87 \\
\hline Tightness factor (tex ${ }^{0.5 *} \mathrm{~mm}^{-1}$ ) & 1.80 & 0.03 & 5 & 0 (due to missing values) \\
\hline Length shrinkage (\%) & 4.99 & 0.06 & 5 & 0 (due to missing values) \\
\hline Width shrinkage (\%) & 4.99 & 0.06 & 19 & 0 (due to missing values) \\
\hline Machine diameter (inches) & 18.99 & 0.22 & 24 & 0 (due to missing values) \\
\hline Machine gauge (inches) & 23.99 & 0.28 & 157.31 & 1.18 (due to missing values) \\
\hline Actual GSM & 152.43 & 2.11 & 88.91 & 80.28 \\
\hline Fabric width (cm) & 83.67 & 0.89 & & \\
\hline
\end{tabular}

SUMMARY OF PARAMETERS USED FOR TRAINING DATASET (FOR 6,432 FABRIC SAMPLES)

\begin{tabular}{|l|c|c|c|c|}
\hline \multicolumn{1}{|c|}{ Parameters } & Mean & $\begin{array}{c}\text { Standard } \\
\text { deviation }\end{array}$ & $\begin{array}{c}\text { Maximum } \\
\text { value }\end{array}$ & $\begin{array}{c}\text { Minimum } \\
\text { value }\end{array}$ \\
\hline Actual linear density (tex) & 15.31 & 0.33 & 17 & 14.10 \\
\hline Lea weight (gms) & 1.68 & 0.04 & 1.87 & 68.30 \\
\hline Lea strength (Ibs) & 57.28 & 8.31 & 78.49 & 33.68 \\
\hline Twist multiplier (tpcm* tex ${ }^{0.5}$ ) & 35.09 & 0.37 & 36.98 & 2.01 \\
\hline Loop Length (mm) & 2.18 & 0.05 & 2.42 & 21.67 \\
\hline Course per cm & 24.99 & 0.72 & 27.98 & 16.48 \\
\hline Wales per cm & 18.32 & 0.39 & 19.88 & 19 \\
\hline Machine diameter (inches) & 19 & - & 19 & 24 \\
\hline Machine gauge (inches) & 24 & - & 24 & 80.28 \\
\hline Fabric width (cm) & 83.67 & 0.89 & 88.91 & \\
\hline
\end{tabular}


SUMMARY OF PARAMETERS USED FOR TESTING DATASET (FOR 1,073 FABRIC SAMPLES)

\begin{tabular}{|l|c|c|c|c|}
\hline \multicolumn{1}{|c|}{ Parameters } & Mean & $\begin{array}{c}\text { Standard } \\
\text { deviation }\end{array}$ & $\begin{array}{c}\text { Maximum } \\
\text { value }\end{array}$ & $\begin{array}{c}\text { Minimum } \\
\text { value }\end{array}$ \\
\hline Actual linear density (tex) & 15.34 & 0.33 & 16.95 & 14.3 \\
\hline Lea weight (gms) & 1.68 & 0.04 & 1.86 & 68.13 \\
\hline Lea strength (Ibs) & 57.36 & 8.08 & 78.49 & 33.91 \\
\hline Twist multiplier (tpcm* tex ${ }^{0.5}$ ) & 35.13 & 0.38 & 36.92 & 2.03 \\
\hline Loop length (mm) & 2.18 & 0.05 & 2.41 & 21.76 \\
\hline Course per cm & 24.91 & 0.73 & 27.43 & 16.54 \\
\hline Wales per cm & 18.28 & 0.39 & 19.60 & 19 \\
\hline Machine diameter (inches) & 19 & - & 19 & 24 \\
\hline Machine gauge (inches) & 24 & - & 24 & 81.28 \\
\hline Fabric width (cm) & 83.89 & 0.82 & 88.30 & \\
\hline
\end{tabular}

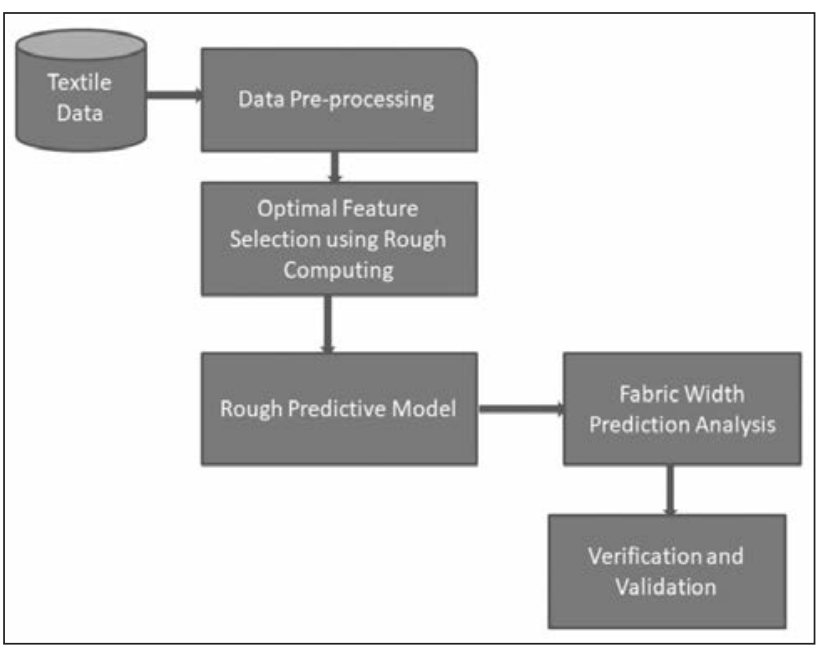

Fig. 1. Rough Computational Based Priority Prediction Model Architecture

\section{Data preprocessing}

Data preprocessing under data mining plays a vital role in data analysis. Various data preprocessing methods such as data cleaning, data transformation, data integration, and data reduction were used to ensure the quality data for data mining models. In data mining, the variables measured at different scales do not contribute equally to the data analysis. To overcome this problem, we need to transform the data to comparable scale values. Data standardizing is one type of data transformation method which converts all variables value into the same scale. The appropriate standardization method depends on the dataset and the conventions of a particular field of study.

In this research work, the textile datasets are preprocessed by using various data preprocessing methods. Z-score data standardization method is used to normalize the textile data.

$$
N T_{D}=\frac{T_{D}-\mu_{T_{D}}}{\sigma_{T_{D}}}
$$

where: $N T_{D}$ is normalized value of the textile attributes;
$T_{D}$ - the actual textile attributes value;

$\mu_{T_{D}}$ - mean of textile attributes value; $\sigma_{T_{D}}$ - standard deviation of textile attributes

Z-score data standardization method works better for large datasets and provides proper scaling than minmax and decimal scaling methods.

\section{Optimal attribute selection using rough set computing}

Soft Computing plays a significant role in scientific applications. Rough set [11, 16, 17, 18, 21] and fuzzy are the two hands of soft computing. The information system consists of many attributes, and these attributes are used to predict the class label. Selection of significance attribute(s) for the classification process yields a good prediction model. Attribute selection process directs to electing a subset of attributes from the broad set of attributes. The aim of the attribute selection is to find the important attribute, remove the irrelevant attribute and construct a novel predictive model. The minimum computation time of the algorithm and excellent accuracy of the predictive model are the two significant advantages of attribute selection. The research community has studied intensively the attribute selection methods for various applications. In this research work, the rough set computing is applied to identify the important attributes from the large dataset of the textile information system.

\section{Rough set attribute dependency}

Attribute dependency in the rough set can be interpreted as the combination of objects in knowing the values of attributes. This checks the degree of dependency between the two attributes. Every attribute produces the indiscernibility among the given two rough sets. Indiscernibility relation concept in the rough sets defines the association between the set of attributes. The same indiscernible objects can be represented redundantly.

Let $U_{s}$ be the universe and let $R S \subseteq U_{s} \times U_{s}$ be an equivalence relation on $U_{s}$, called an indiscernibility 
relation. The pair $A=\left(U_{s}, R S\right)$ is called an approximation space. The lower and upper approximation of set $X$ with respect to $R S$ can be written as:

$$
\begin{aligned}
& \underline{R S}(X)=\left\{x \in U_{S}:[x]_{R S} \subseteq X\right\} \\
& \overline{R S}(X)=\left\{x \in U_{S}:[x]_{R S} \cap X \neq \varnothing\right\}
\end{aligned}
$$

where $[x]_{R S}=\left\{y \in U_{S} \mid x R S y\right\}$ is the equivalence class of $x$; if $[x]_{R S} \subseteq X$, then it is certain that $x \in X$; if $[x]_{R S} \subseteq X-\overline{R S}(X)$ then it is clear that $x \not \subset X$; $[x]_{R S} \subseteq X$ is said to be rough with respect to $R S$ iff $\underline{R S}(X) \neq \overline{R S}(X)$. Otherwise $X$ is $R S$-discernible. A set of attributes $B$ depends on the set of attributes $A$ is given as follows:

$$
A \Rightarrow B
$$

where the attributes of $B$ are uniquely determined by the values of attributes of $A$. $B$ completely depends on the values of $A$ if there exists in the functional dependency relationship in between them. The functional dependency depicts that both the $A$ and $B$ are subsets with each other. Suppose if $B$ depends completely on $C$ then with a degree of $k$ then it can be as $k(0<=k<=1)$ denoted by the positive region,

$$
A \Rightarrow{ }_{k} B
$$

where the positive region $C$ is given as

$$
\operatorname{POS}_{B}(A)=\underset{B \in I / \ln d}{\bigcup} \underline{R B}
$$

So for all the elements in the universe, $I$ in terms of $A$ and $B$ can be given as

$$
\gamma(A, B)=\left|\operatorname{POS}_{A}(B)\right| /|I|
$$

Here the dependency of $B$ on $A$ depends on the value of $k$; if $k=1$ then we can say that $B$ depends on $A$ completely and if $k<1$ then it states that $B$ depends on $A$ but partially. The $k$ expresses the blocks of partition $I / B$ with respect to $A$ and it is termed as the degree of dependency.

\section{Rough set based optimal attributes}

The optimal attributes are determined using the concept of reducts and core in rough set theory. Due to this indiscernibility relation, it becomes ease in finding the redundant values or the redundant attributes of a set. The several set approximation subsets of attributes, which exists in minimal are termed as reducts. The set of all the conditional attributes of set approximations that exists as a set is defined as a core, and in simple, it is the intersection of all the reducts to a set or a system considered. For example, let $T$ be a set of attributes and let the attribute $R$ be the subset of attribute $C$ then it is depicted as below:

$$
T=(U, R, D) / / \text { independent of } C
$$

Then the positive relation is given as

$$
\begin{aligned}
\operatorname{POS}_{R}(D) & =\operatorname{POS}_{C}(D) \\
\text { i.e. } \quad \operatorname{CORE}(C) & =\cap \operatorname{RED}(C)
\end{aligned}
$$

where $\operatorname{CORE}(C)$ defines all the conditional attributes and $\operatorname{RED}(C)$ defines all the set of reducts of attribute $C$. One of the approaches for these reducts or the conditional attributes is done dynamically and depicted by the decision tables. In these decision tables, the attributes are classified in two ways as relevant and often. When the attributes are more often repeated it is given as majority or relevant and the set of attributes appearing as common to the original sets in decision tables are given through as often.

\section{Priority Bayes Classifier}

The Data science has several classification algorithms like Support Vector Machine (SVM), Decision Tree, Back Propagation Neural Network (BP-NN), Rule-based Classification and Naïve Bayesian Classification. Although NN and SVM techniques offer reasonably good solutions for textile problems, researchers have also tried using the Naive Bayes algorithm. Naïve Bayes is one of the well-known and highly scalable classification algorithms, which uses Bayes' theorem to calculate conditional probabilities for the determination of unknown class values of samples. A Naive Bayesian classifier method is a set of a supervised learning algorithm based on applying Bayes' theorem with the "naive" assumption of liberty between each pair of features. Bayes' theorem states the following relationship for a given class variable and a dependent feature vector $x_{1}$ through $x_{n}$ :

$$
P\left(y / x_{1}, \ldots, x_{n}\right)=\frac{P(y) P\left(x_{1}, \ldots, x_{n} \mid y\right)}{P\left(x_{1}, \ldots, x_{n}\right)}
$$

- $P(y / x)$ is the posterior probability of decision attribute class $(y$, target) given predictor ( $x$, attributes).

- $P(y)$ is the prior probability.

- $P(x / y)$ is the likelihood which is the probability of predictor for a given class.

- $P(x)$ is the prior probability.

In our research work, the data were represented as a continuous attribute. To handle such a data, extension version of Naïve Bayes method is used to develop priority based prediction model. This extension of naive Bayes is called Gaussian Naive Bayes. It is also assumed that all the features are following a Gaussian distribution. Instead of assuming conditional independence of $x_{j}$, the dependence relation of $x_{j}$ is encoded in the covariance matrix as in Gaussian distribution $P(x / y)$.

$$
P(x / y)=\frac{1}{\sqrt{(2 \pi)^{D} \operatorname{det}(\Sigma)}} \exp \left(-\frac{1}{2}(x-\mu)^{T} \Sigma^{-1}(x-\mu)\right)
$$

where $\mu$ is mean, $\Sigma$ - covariance matrix and $D-\operatorname{dim}$ $(x)$. In the prediction model, the attributes are assigned priority based on the attribute significance or dependency approximation value while computing posterior probability as shown in table 4.

The rough computational based priority prediction model (RCPPM) algorithm is given below. 
PRIORITY ASSIGNMENT BASED ON ROUGH SET ATTRIBUTES SIGNIFICANCE APPROXIMATION

\begin{tabular}{|l|c|c|}
\hline Name of the attribute & $\begin{array}{c}\text { Attribute } \\
\text { significance } \\
\text { approximation } \\
\text { value }\end{array}$ & $\begin{array}{c}\text { Priority } \\
\text { assignment }\end{array}$ \\
\hline $\begin{array}{l}\text { Nominal linear density } \\
\text { (tex) }\end{array}$ & 0.20 & 10 \\
\hline $\begin{array}{l}\text { Actual linear density } \\
\text { (tex) }\end{array}$ & 1.00 & 1 \\
\hline Lea weight (gms) & 0.72 & 3 \\
\hline Lea strength (lbs) & 0.25 & 9 \\
\hline $\begin{array}{l}\text { Twist multiplier } \\
\text { (tpcm* tex }{ }^{0.5} \text { ) }\end{array}$ & 0.98 & 2 \\
\hline Loop length (mm) & 0.64 & 4 \\
\hline Course per cm & 0.30 & 8 \\
\hline Wales per cm & 0.30 & 7 \\
\hline $\begin{array}{l}\text { Length } \\
\text { shrinkage (\%) }\end{array}$ & 0.15 & 11 \\
\hline Width shrinkage (\%) & 0.15 & 12 \\
\hline $\begin{array}{l}\text { Machine diameter } \\
\text { (inches) }\end{array}$ & 0.35 & 5 \\
\hline Machine gauge (inches) & 0.35 & 6 \\
\hline
\end{tabular}

\section{Proposed RCPPM Algorithm}

\begin{tabular}{ll}
\hline Input: & $T_{D}:$ Textile Data, $n:$ number of attributes \\
Output: & $R C P P M$ Model
\end{tabular}

Step 1: Remove noisy and missing values using data preprocessing methods

Step 2: Standardize the textile data using Z-Score Normalization

$$
N T_{D}=\frac{T_{D}-\mu_{T_{D}}}{\sigma_{T_{D}}}
$$

Step 3: Select the optimal attribute for the prediction model from the large textile data

3.1. Calculate approximation values for all attributes using equation (17),

$\sigma_{(P, Z)}(a)=\frac{\left(\operatorname{card}\left(\operatorname{POS}_{p}(Z)\right)-\left(\operatorname{card}\left(\operatorname{POS}_{p-(a)}(Z)\right)\right)\right.}{\operatorname{card}(U)}$

3.2. Compare the approximation values of each attribute $a j$,

3.3. If both attributes are highly associated then remove the less approximation value attribute(s).

Step 4: For each $j=i+1$ to $n$ Do

4.1. Calculate a value for all class labels

$$
P\left(y / x_{1}, \ldots, x_{n}\right)=\frac{P(y) P\left(x_{1}, \ldots, x_{n} \mid y\right)}{P\left(x_{1}, \ldots, x_{n}\right)}
$$

4.2. Compare the class labels value and predict the fabric width. next $j$
In this research work, the existing Bayesian algorithm is modified and proposed novel rough computational based priority prediction model (RCPPM) algorithm as shown above. RCPPM algorithm has two parts: first part deals with selection of optimal attributes using rough computational based optimal attribute selection (RCOAS) method and second part deals with development of RCPPM prediction model. The real-time textile dataset $T_{D}$ may have missing values and these values are replaced by using missing value analysis. Then the dataset are first standardized (normalized) to overcome the deviation of the scale between the different attributes. Normalization is classified into range normalization-score and decimal scaling. In the proposed algorithm, the Z-score normalization $N T_{D}$ is applied to standardize the dataset. This process helps to improve the accuracy of the prediction model. Then the normalized dataset are given as input to RCOAS algorithm to find the optimal attribute(s) and the output of RCOAS algorithm is supplied to the Gaussian Naive Bayes based RCPPM algorithm to predict the fabric width. The RCPPM proposed model performance is compared with the ground truth textile dataset which is collected from the Tirupur knitting industry. Finally, the RCPPM performance is compared with various prediction models.

\section{RESULTS AND DISCUSSION}

Tirupur is one of the crucial textile export zones in Tamilnadu. The real-time dataset was collected from the Tirupur knitting industry. The summary of the entire dataset is shown in table 1, which consists entirely of 16 textile attributes. The first 15 are conditional attributes and fabric width $(\mathrm{cm})$ is a decision attribute. The data pre-processing procedures such as missing value analysis and data standardization are applied to produce reliable data. Z-score normalization was applied to textile dataset and the corresponding normalized values used for our proposed model. Feature/attribute selection is the most commonly used technique in data mining to reduce redundant or irrelevant data.

The proposed RCPPM algorithm is developed using matlab codes for finding the optimal attribute(s) and for prediction model to predict optimal fabric width for single jersey finished cotton knitted fabric. The first part of the proposed algorithm is to find optimal attributes among the various textile conditional attributes using rough set techniques. The attributes are to be classified based on the attribute significance value which we obtained through the computational program. From the table 5, It should be clear that some of the conditional attributes such as stitch density, tightness factor, actual GSM are not considered because of their less importance during optimal attribute selection and also observed that the significant attribute score of the width shrinkage and length shrinkage are less when compared to the other conditional attributes. Based on the rough set Core and Reduct concepts, all the above-said attributes are 
removed from the input knowledge data and also two reducts (set of 4 and 9 attributes) and one core (set of 4 attributes) are identified. Either use 4 or 9 attributes as optimal attributes based on attribute significance value with decision attribute fabric width as input knowledge data to the prediction model RCPPM.

Table 5

ROUGH SET BASED ATTRIBUTE SIGNIFICANCE APPROXIMATION VALUES

\begin{tabular}{|l|c|}
\hline \multicolumn{1}{|c|}{ Name of the attributes } & $\begin{array}{c}\text { Attribute } \\
\text { significance } \\
\text { approximation } \\
\text { values }\end{array}$ \\
\hline Nominal linear density (tex) & 0.20 \\
\hline Actual linear density (tex) & 1.00 \\
\hline Lea weight (gms) & 0.72 \\
\hline Lea strength (lbs) & 0.25 \\
\hline Twist multiplier (tpcm * tex ${ }^{0.5}$ ) & 0.98 \\
\hline Loop length (mm) & 0.64 \\
\hline Course per cm (CPcm) & 0.30 \\
\hline Wales per cm (WPcm) & 0.30 \\
\hline Length shrinkage (\%) & 0.15 \\
\hline Width shrinkage (\%) & 0.15 \\
\hline Machine diameter (inches) & 0.35 \\
\hline Machine gauge (inches) & 0.35 \\
\hline
\end{tabular}

Based on the RCOAS algorithm output, the optimal attributes obtained, are actual linear density (tex), twist multiplier (tpcm * tex ${ }^{0.5}$ ), lea weight (gms), loop length $(\mathrm{mm})$, machine diameter (inches), machine gauge (inches), WPcm, CPcm and lea strength (lbs) respectively from the supplied textile dataset as summarized in table 1. The importance of each textile attribute is shown in figure 2 based on their attribute significance value. Then the selected optimal

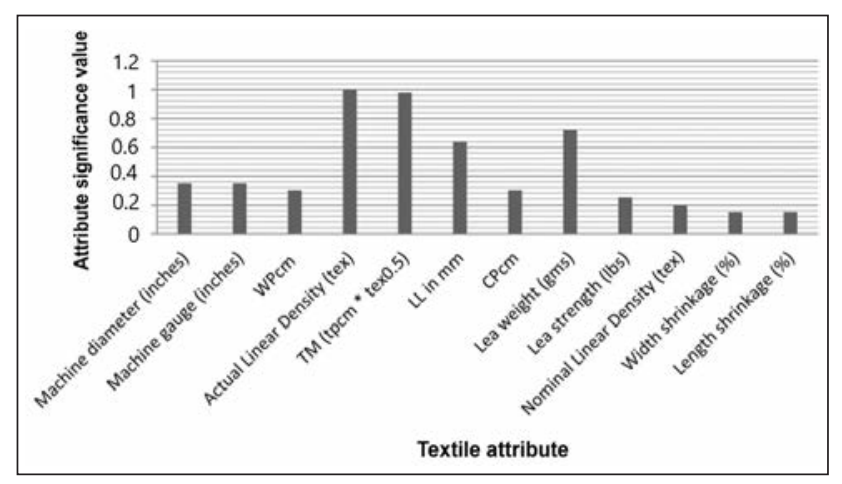

Fig. 2. Textile Attribute Vs Attribute significance value

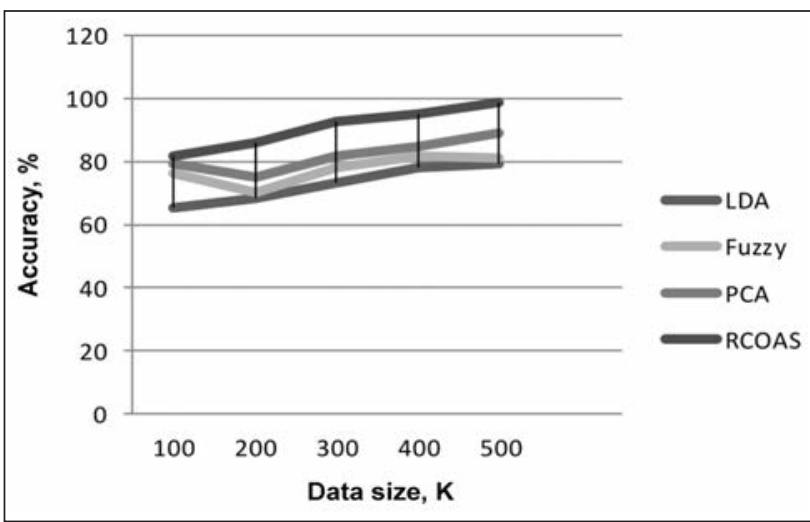

Fig. 3. Performance of various attribute selection methods

attribute(s) are supplied to the RCPPM prediction model to predict the value of fabric width.

Many feature selection methods are used by the research community in various engineering applications such as Principal Component Analysis (PCA) [19], Linear Discriminant Analysis (LDA) [20] and Fuzzy based analysis [21]. The performance of the proposed RCOAS method is compared with the above-said methods. The performance of the proposed method is better than other attribute selection methods as shown in the figure 3 .

Table 6

\begin{tabular}{|c|c|c|c|c|c|c|c|}
\hline \multicolumn{5}{|c|}{ PREDICTED VALUES OF FABRIC WIDTH FOR TESTING DATASET FABRIC SAMPLES } \\
\hline \multirow{2}{*}{$\begin{array}{c}\text { Sample } \\
\text { no. }\end{array}$} & $\begin{array}{c}\text { Actual value } \\
\text { of fabric } \\
\text { width }\end{array}$ & \begin{tabular}{c} 
ANN \\
\cline { 3 - 8 }
\end{tabular} & $\begin{array}{c}\text { Predicted } \\
\text { value }\end{array}$ & Error (\%) & $\begin{array}{c}\text { Predicted } \\
\text { value }\end{array}$ & Error (\%) & \multicolumn{3}{c|}{$\begin{array}{c}\text { Predicted } \\
\text { value }\end{array}$} & Error (\%) \\
\hline 1 & 83.06 & 83.009914 & 0.0603 & 83.01822 & 0.0503 & 83.024865 & 0.0423 \\
\hline 2 & 83.51 & 83.459726 & 0.0602 & 83.451375 & 0.0702 & 83.475677 & 0.0411 \\
\hline 3 & 84.25 & 84.190519 & 0.0706 & 84.190519 & 0.0706 & 84.206358 & 0.0518 \\
\hline 4 & 83.66 & 83.609385 & 0.0605 & 83.592653 & 0.0805 & 83.632810 & 0.0325 \\
\hline 5 & 83.85 & 83.799522 & 0.0602 & 83.824677 & 0.0302 & 83.813022 & 0.0441 \\
\hline 6 & 84.77 & 84.708541 & 0.0725 & 84.759403 & 0.0125 & 84.741856 & 0.0332 \\
\hline 7 & 82.53 & 82.467937 & 0.0752 & 82.486919 & 0.0522 & 82.503177 & 0.0325 \\
\hline 8 & 82.38 & 82.324146 & 0.0678 & 82.326617 & 0.0648 & 82.345894 & 0.0414 \\
\hline 9 & 84.42 & 84.363016 & 0.0675 & 84.37145 & 0.0575 & 84.382433 & 0.0445 \\
\hline 10 & 83.53 & 83.477960 & 0.0623 & 83.503019 & 0.0323 & 83.501850 & 0.0337 \\
\hline
\end{tabular}


Based on the optimal attribute selection, the prediction model was developed as second part of the RCPPM algorithm. The proposed RCPPM algorithm performance is compared with ANN (Artificial Neural Network) Model [8, 9, 10] and ANN with PSO [22] (Artificial Neural Network with Particle Swarm Optimization). All the prediction models are developed with 6,432 training fabric samples and tested with 1,073 testing fabric samples. The cross k-validation method is used to split the textile dataset accurately into training and testing to overcome the unbalanced dataset problem. The prediction is done based on various machine diameters such as 19, 20, 21, 22 and 23 inches. Table 6 contains the actual and predicted values of fabric width for a few testing dataset fabric samples from which it is apparent that predicted values compare favourably with experimental values which shows the reliability of our proposed prediction model RCPPM.

Various critical performance metrics are available to evaluate the performance of the proposed RCPPM model such as Root Mean Square Error (RMSE), Mean Square Error (MSE) and Absolute Error (AE). Our prediction model performance is evaluated using the MSE performance metric. Table 7 shows the MSE

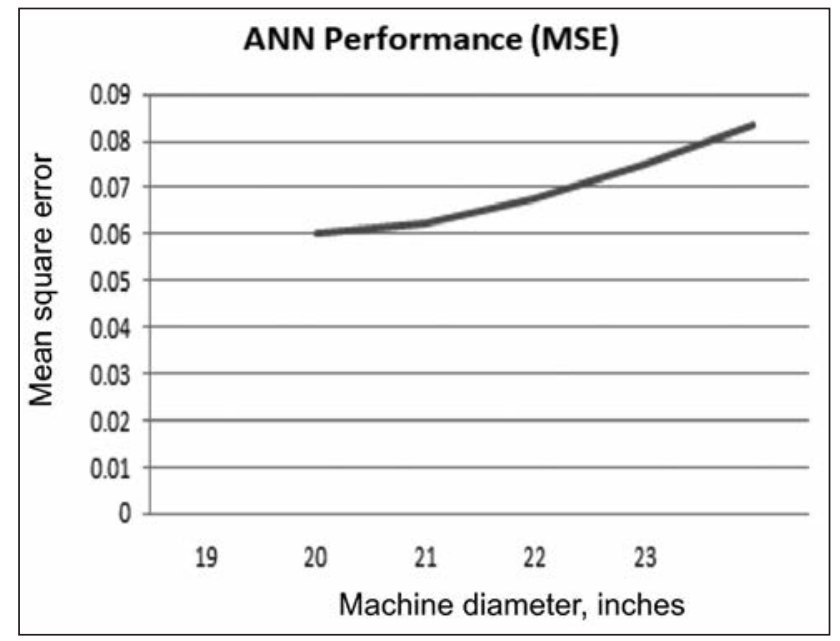

a

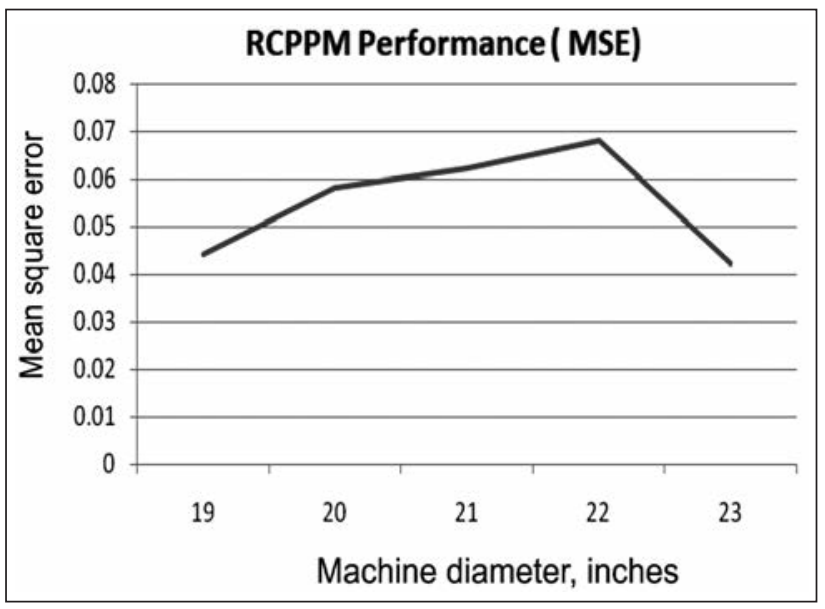

C

\begin{tabular}{|c|c|c|c|}
\hline \multicolumn{2}{|c|}{\begin{tabular}{c} 
Table 7 \\
\hline $\begin{array}{c}\text { COMPARISON OF RCPPM PERFORMANCE (MSE) } \\
\text { WITH OTHER PREDICTION MODELS }\end{array}$ \\
\hline $\begin{array}{c}\text { Machine } \\
\text { diameters } \\
\text { (inches) }\end{array}$
\end{tabular} ANN } & $\begin{array}{c}\text { ANN with } \\
\text { PSO }\end{array}$ & RCPPM \\
\hline 19 & 0.0602 & 0.054 & 0.044 \\
\hline 20 & 0.0621 & 0.057 & 0.058 \\
\hline 21 & 0.0678 & 0.106 & 0.062 \\
\hline 22 & 0.0752 & 0.072 & 0.068 \\
\hline 23 & 0.0836 & 0.081 & 0.0421 \\
\hline
\end{tabular}

value for ANN, ANN with PSO and RCPPM for 5 different machine diameters.

Figures 4, a-d show the performance of ANN, ANN with PSO, RCPPM, and comparison of all three prediction models based on MSE performance metric respectively. The MSE values change based on the machine diameter values. In the case of ANN model, the MSE value increases as the machine diameter value increases. The ANN model is optimized with PSO, where the MSE value is small for 19, 20 machine diameter, and it is very high when machine
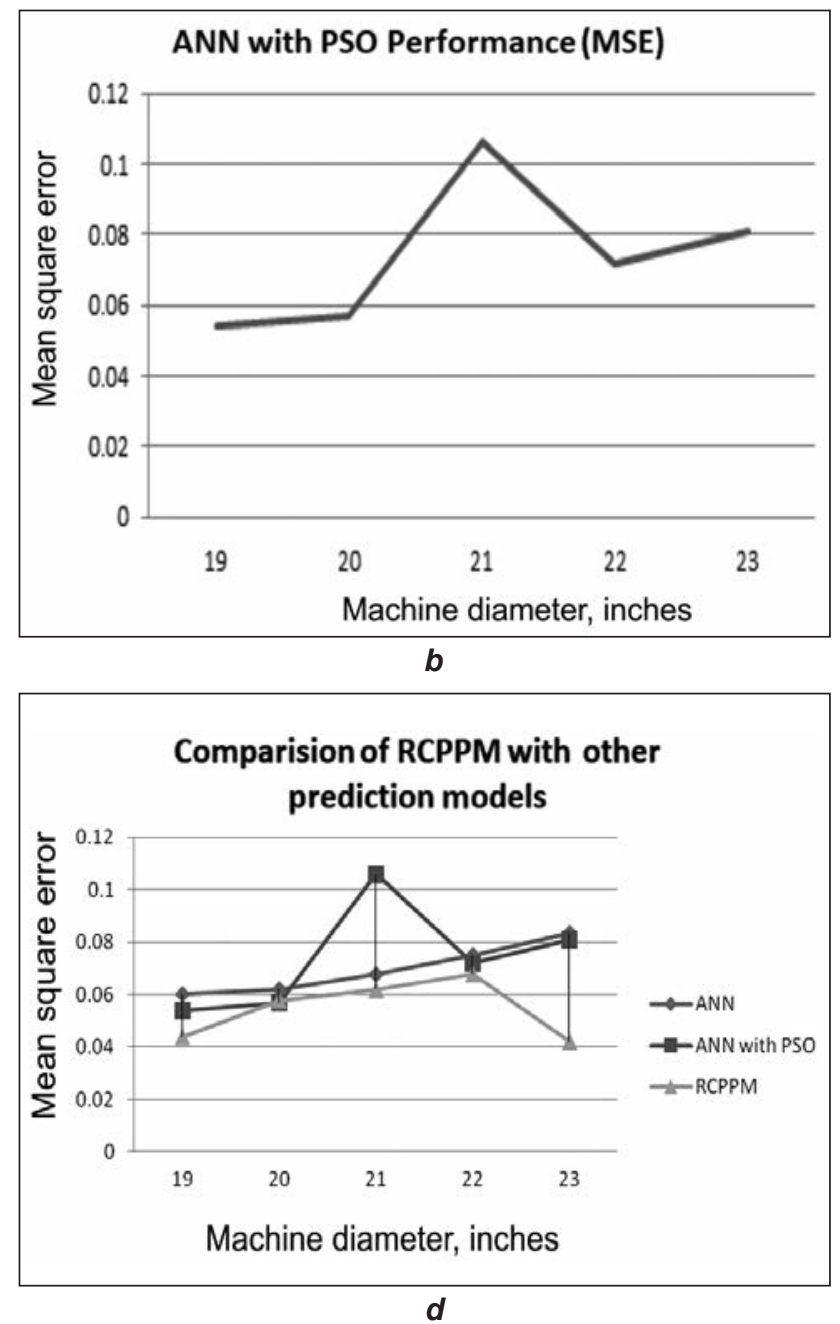

Fig. 4. Dependency of MSE with various approaches: $a-\mathrm{ANN}, b-\mathrm{ANN}$ with PSO, $c-\mathrm{RCPPM}, d-$ comparison of RCPPM with other prediction models 
diameter value is 21 . The performance of the proposed model RCPPM is checked with various machine diameters. The MSE values of the proposed model are less for all the cases of machine diameter compared with ANN and ANN with PSO. The simple ANN model shows a gradual increase in MSE as the machine diameter increases. The ANN with PSO performed on it decreases its error for all machine diameters but one. The comparison graph shows that the proposed RCPPM model outperforms both ANN and ANN with PSO prediction models.

\section{CONCLUSIONS}

Knitted structures offer easy-care property, high elasticity, air permeability, flexibility, etc., in comparison to woven fabrics. During the various stages of knitting, making up and of end use, a lot of problems are encountered. The most important problem is choosing optimum fabric width during the garment manufacturing process. Textile industry needs the model to predict the fabric width accurately to overcome the unwanted textile wastage and provide the smart environment in textile production. In this research work, one of the soft computing techniques namely rough set approach was used for an attribute or feature selection and developed rough computational optimal attribute selection (RCOAS) method to find optimal attributes from a large amount of textile data and its performance is found to be better than those of other existing feature selection methods. Based on the selected optimal attributes, the rough computational based priority prediction model (RCPPM) is developed with the help of Gaussian Naïve Bayes algorithm. This proposed model with the inputs is used to predict fabric width in fabric manufacturing process in the textile domain. Attempts can be made to optimize the developed model further. The results show that the relationship between the predicted width and the measured width is good. The proposed algorithm is tested with real-time textile dataset collected from Tirupur knitting industry and, doubtless, will be of use to manufacturers of the knitted garment. Our future work will be extended to propose a new algorithm for handling big or large textile dataset effectively using Hadoop framework.

\section{REFERENCES}

[1] Gravas, E., Kiekens, P., Langenhove, L., Predicting fabric weight per unit area of single-and double-knitted structures using appropriate software, In: Autex Research Journal, 2006, 6, 4, 223-237

[2] Panda, P.K., Sumanta, B., Single jersey cotton knit: Finished width prediction by ANN, In: The Indian Textile Journal, 2013

[3] Yildirim, P., Birant, D., Alpyildiz, T., Data mining and machine learning in textile industry, In: Wiley Interdisciplinary Reviews: Data Mining and Knowledge Discovery, 2018, 8, 1, 1228

[4] Majumdar, A., Soft computing in fibrous materials engineering, In: Textile Progress, 2011, 43, 1, 1-95

[5] Mozafary, V., Payvandy, P., Application of data mining technique in predicting worsted spun yarn quality, In: The Journal of The Textile Institute, 2014, 105, 1, 100-108

[6] Gsell, E., Heimlich, F., Ehrmann, A., Weber, M.O., Dependence of dry, wet and washing relaxation on knitted structures and fabric parameters, In: Industria Textila, 2017, 68, 2, 121-125, https://doi.org/10.35530// IT.068.02.1333

[7] Akyol, U., Tüfekci, P., Kahveci, K., Cihan, A., A model for predicting drying time period of wool yarn bobbins using computational intelligence techniques, In: Textile Research Journal, 2015, 85, 13, 1367-1380

[8] Matusiak, M., Application of artificial neural networks to predict the air permeability of woven fabrics, In: Fibres \& Textiles in Eastern Europe, 2015

[9] Golob, D., Osterman, D.P., Zupan, J., Determination of pigment combinations for textile printing using artificial neural networks, In: Fibres \& Textiles in Eastern Europe, 2008, 16, 3, 68

[10] Furferi, R., Governi, L., Volpe, Y., Modelling and simulation of an innovative fabric coating process using artificial neural networks, In: Textile Research Journal, 2012, 82, 12, 1282-1294

[11] Przybyła-Kasperek, M., Feature selection based on the rough set theory and dispersed system with dynamically generated disjoint clusters, In: INnovations in Intelligent SysTems and Applications (INISTA), 2017, IEEE International Conference, 223-228

[12] Elzaher, Eltahan, E.A., Sultan, M., Mito, A.B., Determination of loop length, tightness factor and porosity of single jersey knitted fabric, In: Alexandria Engineering Journal, 2016, 55, 2, 851-856

[13] Kalkanci, M., Sinecen, M., Kurumer, G., Prediction of dimensional change in finished fabric through Artificial Neural Networks, In: Tekstil Ve Konfeksiyon, 2018, 28, 1, 51-60

[14] Hossain, A.M., Kabir, A.Z., Customization of Starfish technology in the production of cotton-knit fabrics: A practical approach, In: International Journal of Engineering \& Technology, 2011, 11, 1, 125-139

[15] Anbumani, N., Knitting Fundamentals, Machines, Structures and Developments, In: New Age International Publishers, 2006

[16] Pawlak, Z., Rough set theory and its applications to data analysis, In: Cybernetics \& Systems, 1998, 29, 7, 661-688

[17] Pawlak, Z., Skowron, A., Rudiments of rough sets, In: Information sciences, 2007, 177, 1, 3-27 
[18] Thangavel, K., Pethalakshmi, A., Dimensionality reduction based on rough set theory: A review, In: Applied Soft Computing, 2009, 9, 1, 1-12

[19] Eldessouki, M., Hassan, M., Qashqary, K., Shady, E., Application of principal component analysis to boost the performance of an automated fabric fault detector and classifier, In: Fibres \& Textiles in Eastern Europe, 2014, 22, 51-57

[20] Li, C.H., Kuo, B.C., Lin, C.T., LDA-based clustering algorithm and its application to an unsupervised feature extraction, In: IEEE Transactions on Fuzzy Systems, 2011, 19, 1, 152-163

[21] Arthi, K., Tamilarasi, A., Prediction of autistic disorder using neuro fuzzy system by applying ANN technique, In: International journal of developmental neuroscience, 2008, 26, 7, 699-704

[22] Ding, W., Lin, C.T., Prasad, M., Cao, Z., Wang, J., A Layered-Coevolution-Based Attribute-Boosted Reduction Using Adaptive Quantum-Behavior PSO and Its Consistent Segmentation for Neonates Brain Tissue, In: IEEE Transactions on Fuzzy Systems, 2018, 26, 3, 1177-1191

\section{Authors:}

\section{BHUVANESHWARRI ${ }^{1}$, A. TAMILARASI ${ }^{2}$}

${ }^{1}$ Ph.D., Research Scholar in Information and Communication Engineering, Anna University, Chennai - 600 025, TAMILNADU, INDIA

Assistant Professor (Senior), Department of IT, Institute of Road and Transport Technology,

Vasavi college post, Erode - 638 316, INDIA

e-mail: pbw.irtt@gmail.com

${ }^{2}$ Professor \& Head, Department of Computer Applications, Kongu Engineering College,

Perundurai, Erode - 638 060, INDIA

e-mail: drtamil@kongu.ac.in

Corresponding author:

I. BHUVANESHWARRI

e-mail: pbw.irtt@gmail.com 


\title{
Creativity, innovation and future - the key points regarding the "architecture" for the production of agro-textiles
}

\author{
DOI: 10.35530/IT.070.06.1624
}

EFTALEA CĂRPUS

ANGELA DOROGAN

VALENTIN VLĂDUT

MIHAI-GABRIEL MATACHE

ADRIANA MUSCALU

\section{ABSTRACT - REZUMAT}

\section{Creativity, innovation and future - the key points regarding the "architecture" for the production of agro-textiles}

The twenty-first century represents the period of the most remarkable discoveries and transformations of the human civilization, but also the period of the most important changes regarding the evolution of the environment. At the present stage of the evolution of the society, the knowledge of the behaviour of the world economy cannot be conceived outside the environmental approach, as a system, structure and dynamics, its connections and implications on life on earth. Agriculture is an important source of emission of two greenhouse gases with a significant share in the influence of the global warming process. The key to protecting the environment from the harmful effects of widespread and unsafe farming practices is through implementing sustainable practices. Sustainable agriculture incorporates both the conservation of available resources and the use of agricultural practices aimed at protecting the environment.

Given the increasing awareness of the environment and the specific knowledge of the various interdisciplinary technologies, special attention has been paid to unconventional technical applications, such as the use of textile structures in the agriculture and horticulture sectors to increase the quality and efficiency of agro-food products in terms of ensuring a healthy environment, social economic equity and a profitable economy.

In this context, the textile sector and the field of technical textiles, through the potential of functionalities, can make a special contribution to achieving a level of coherence between agriculture, environment and rural development through the intelligent and sustainable capitalization of agricultural lands and labour force.

For agro-textiles - weight domain for the technical textile sector - design is a problem-solving approach, based on common human technical/scientific skills or knowledge, which starts from understanding and observing the phenomena of the field in which these textile elements/products will be used. In this sense, the paper presents the logical matrix regarding the interactions between the problems that need to be solved, the elements that can influence the studied phenomenon the functions that the designed product has to fulfill and the effects produced by its use under real conditions of use.

Keywords: agro-textiles, sustainability, interaction

\section{Creativitate, inovație și viitor - punctele cheie privind "arhitectura" de realizare a agro-textilelor}

SecoluI XXI reprezintă perioada celor mai notabile descoperiri și transformări ale civilizației umane, dar și perioada celor mai importante schimbări în ceea ce privește evoluția mediului înconjurător. În etapa actuală a evoluţiei societăţii, cunoaşterea comportamentului economiei mondiale, nu poate fi concepută în afara abordării mediului înconjurător, ca sistem, structură şi dinamică, conexiuni şi implicaţiile acestuia asupra vieţii pe pământ.

Agricultura reprezintă o importantă sursă de emisie a două gaze cu efect de seră, cu pondere semnificativă în influențarea procesului de încălzire globală. Cheia protejării mediului împotriva efectelor dăunătoare ale practicilor agricole extinse și nesigure este prin implementarea unor practici durabile. Agricultura durabilă încorporează atât conservarea resurselor disponibile, cât și utilizarea practicilor agricole care vizează protecția mediului.

Având în vedere creșterea gradului de conștientizare a mediului și cunoașterea specifică a diferitelor tehnologii interdisciplinare, o atenție deosebită a fost acordată aplicațiilor tehnice neconvenționale, cum ar fi utilizarea structurilor textile în sectoarele agriculturii și horticulturii pentru a spori calitatea și randamentul produselor agroalimentare în condițiile asigurării unui mediu sănătos, a unei echități economice sociale și a unei economii profitabile.

În acest context sectorul textil, respectiv domeniul textilelor tehnice, prin potențialul funcționalităților, poate avea o contribuție deosebită la atingerea unui nivel de coerență între agricultură, mediu și dezvoltare rurală, prin valorificarea inteligentă și durabilă a terenurilor agricole și a forței de muncă.

Pentru agro-textile - domeniu de pondere pentru sectorul textilelor tehnice - proiectarea este o abordare de soluționare a problemelor, bazată pe capacități/cunoștințe tehnice/științifice umane comune, ce pornește de la înțelegerea și observarea fenomenelor domeniului în care se vor utiliza aceste elemente/produse textile. În acest sens, lucrarea prezintă matricea logică privind interacțiunile dintre problemele ce se impun rezolvate, elementele ce pot influența fenomenul studiat, funcțiile pe care trebuie să le îndeplinească produsul proiectat, precum și efectele produse de utilizarea acestuia în condiții reale de utilizare.

Cuvinte-cheie: agro-textile, sustenabilitate, interacțiune 


\section{INTRODUCTION}

Megatrends that will change the world in the coming years - demographic change, globalization, resource scarcity, climate change, dynamic technology and innovation, knowledge-based society, mass customization, global responsibility - define the critical moment in history [1]. Of these, the environmental changes, which will continue in the coming decades, represent growing challenges for food, health and welfare systems and include climate changes, increased ozone at the ground level, changes in water availability, increased carbon dioxide levels, soil degradation, deforestation and land use change. In these circumstances, Europe must embrace a new logic of global socio-economic sustainability, which, in essence, addresses economic success, population well-being and contributes to the conservation of the environment and resources and which is based on adaptation and mitigation strategies aimed at overcoming and/or reversing these changes.

Currently, Romania is in an important moment in which it must adopt a strategic position towards the challenges and the opportunities of wide. In this respect, Romania must maximize the favourable global and European trends, as well as its own competitive advantages. To meet the climate challenges it is necessary to apply the existing interdisciplinary knowledge, as well as to develop a new range of technical and institutional innovations. The research and development activity to facilitate the development of solutions regarding the challenges we have to face can be divided into two categories. One of these is defined from the point of view of a type of research in the field of social sciences, by which can be analyzed the ways chosen by a society to respond in case of future specific changes and can anticipate the types of actions to prevent the occurrence of problems and conflicts. The other is essentially established by the research and development applied strictly in the field of technology and its development. Many technologies can be developed in laboratories, but they will not bring benefits if there is no market price and force to enable and promote their dissemination [2].

The Intergovernmental Panel on Climate Change (IPCC) has a long-term approach, analyzing the potential effects of climate change in relation to their determinants. Table 1 presents these elements synthesized by the IPCC for Europe [3].

Agriculture is an important source of emission of two greenhouse gases with a high potential for global warming: nitrogen oxide $\left(\mathrm{N}_{2} \mathrm{O}\right)$ - with a potential of 310 times higher than $\mathrm{CO}_{2}$ and methane $\left(\mathrm{CH}_{4}\right)$ - with a potential of 21 times higher than $\mathrm{CO}_{2}$. Adaptation to climate change must be fully in line with the activities of the agricultural sector, promote and protect food security and support the sustainable development of the rural environment [4].

To support the development of the agricultural sector, a strategic approach is required, which takes into account, on the one hand, the effects of climate change, by increasing pressures on primary resources - of water and soil and, on the other hand, on the increase in demand of agricultural products and food, related to the prospects of population growth at global level.

The EU pursues three objectives through the Common Agricultural Policy (CAP):

- ensuring a viable food production;

- ensuring the sustainable management of natural resources and actions in the field of climate;

- balanced territorial development.

Member states and regions develop their rural development programs based on the needs of their territories and address at least four of the following common EU priorities set for 2021-2027 [5].

The activity of the CAP, for the period 2012-2027, will focus on nine general objectives that reflect the

\begin{tabular}{|c|c|c|}
\hline \multicolumn{3}{|c|}{ RISKS - ESTIMATIONS - DETERMINING FACTORS } \\
\hline Risks & Estimations & Determining factors \\
\hline $\begin{array}{l}\text { Negative impact due to climate change } \\
\text { on: } \\
\text { - grain yields; } \\
\text { - increasing the variability of yields. }\end{array}$ & $\begin{array}{l}\text { - The estimated impact varies according to the } \\
\text { cultures, region and adaptation scenarios, with } \\
\text { approximately } 10 \% \text { of the projections for the } \\
\text { period } 2030-2049 \text {. } \\
\text { - After } 2050 \text { the risk of a more severe impact } \\
\text { increases and depends on the level of heating. }\end{array}$ & $\begin{array}{l}\text { - Heating trend; } \\
\text { - Drought trend; } \\
\text { - } \mathrm{CO}_{2} \text { fertilization; } \\
\text { - Extreme temperatures; } \\
\text { - Extreme precipitation. }\end{array}$ \\
\hline $\begin{array}{l}\text { - Increasing water restrictions. } \\
\text { - Significant reduction of the amount } \\
\text { of water available from rivers and } \\
\text { underground sources; } \\
\text { - Increasing the demand for water (for } \\
\text { irrigation, energy and industry, } \\
\text { population consumption); } \\
\text { - Increasing the evaporation } \\
\text { phenomenon, especially in southern } \\
\text { Europe. }\end{array}$ & $\begin{array}{l}\text { - Potential of adaptation proven by adopting more } \\
\text { efficient technologies in terms of water use and } \\
\text { water saving strategies; } \\
\text { - Implementation of best practices and } \\
\text { governance tools in river basin management } \\
\text { plans and integrated water management }\end{array}$ & $\begin{array}{l}\text { - Heating trend; } \\
\text { - Drought trend; } \\
\text { - Extreme temperatures. }\end{array}$ \\
\hline
\end{tabular}


importance of the policy from the economic and social point of view and from the environmental point of view [5]:

- supporting a reliable income and the resilience of farms throughout the EU, in order to improve food security;

- improving market orientation and increasing competitiveness, including a strong emphasis on research, technology and digitization;

- improving the position of farmers within the value chain;

- contribution to sustainable energy, as well as mitigation and adaptation to climate change;

- promoting the sustainable development and efficient management of natural resources such as water, soil and air;

- contribution to the protection of biodiversity, improvement of ecosystem services and conservation of habitats and landscapes;

- attracting young farmers and facilitating the development of enterprises in rural areas;

- promoting employment, growth, social inclusion and local development in rural areas, including bioeconomy and sustainable forestry;

- improving the response that EU agriculture offers to the demands of society in terms of food and health, including safe, nutritious and obtained foods through sustainable production, as well as animal welfare.

The key to protecting the environment from the harmful effects of widespread and unsafe farming practices is through sustainable practices. Sustainable agriculture incorporates both the conservation of available resources and the use of agricultural practices aimed at protecting the environment.

Given the increasing awareness of the environment and the specific knowledge of the various interdisciplinary technologies, special attention has been paid to unconventional technical applications, such as the use of textile structures in the agriculture and horticulture sectors to increase the quality and efficiency of agro-food products in the conditions of a healthy environment, of a social economic equity and a profitable economy.
In this context, the textile sector and the field of technical textiles, through the potential of functionalities, can make a special contribution to achieving a level of coherence between agriculture, environment and rural development through the intelligent and sustainable capitalization of agricultural lands and labour force.

\section{METHODOLOGY}

The "agro-textile sector" includes the application of textile products in agriculture, forestry, horticulture, floriculture, fishing segments, landscape, gardening, animal husbandry, aquaculture and agro-engineering and it offers solutions for the major problems in the field, namely: globalization, demographic pressure, resource constraints (water, energy), environmental protection and human health. Agro-textile products can be woven, non-woven or knitted [6] and offers multidimensional solutions for the variety of problems in the agro-food industry as a result of the advantages held by textile structures (flexibility, strength, light weight, protection, etc.).

Agriculture is considered the "backbone of a country" and agro-textiles can be considered "the backbone of agriculture" [7].

According to the report published by Credence Research, "Agro Textile Market - Growth, Future Prospects and Competitive Analysis, 2016-2024", the agro-textile market is expected to grow over $\$ 14,363.2$ by 2025 , with an average annual growth rate (CAGR - compound annual growth rate) of 5.5\% from 2017 to 2025.

In a conceptual century - based on knowledge - the new social, technological and cultural contexts demand a new perspective through a new approach to innovation. The need for new products, with multiple functionalities, able to balance the economic, social and environmental needs, must receive the answers based on a new way of thinking - putting the same concept of human needs, technological resources and constraints, establishing the cognitive link between the knowledge, processes/technologies and the requirements of the field of use.

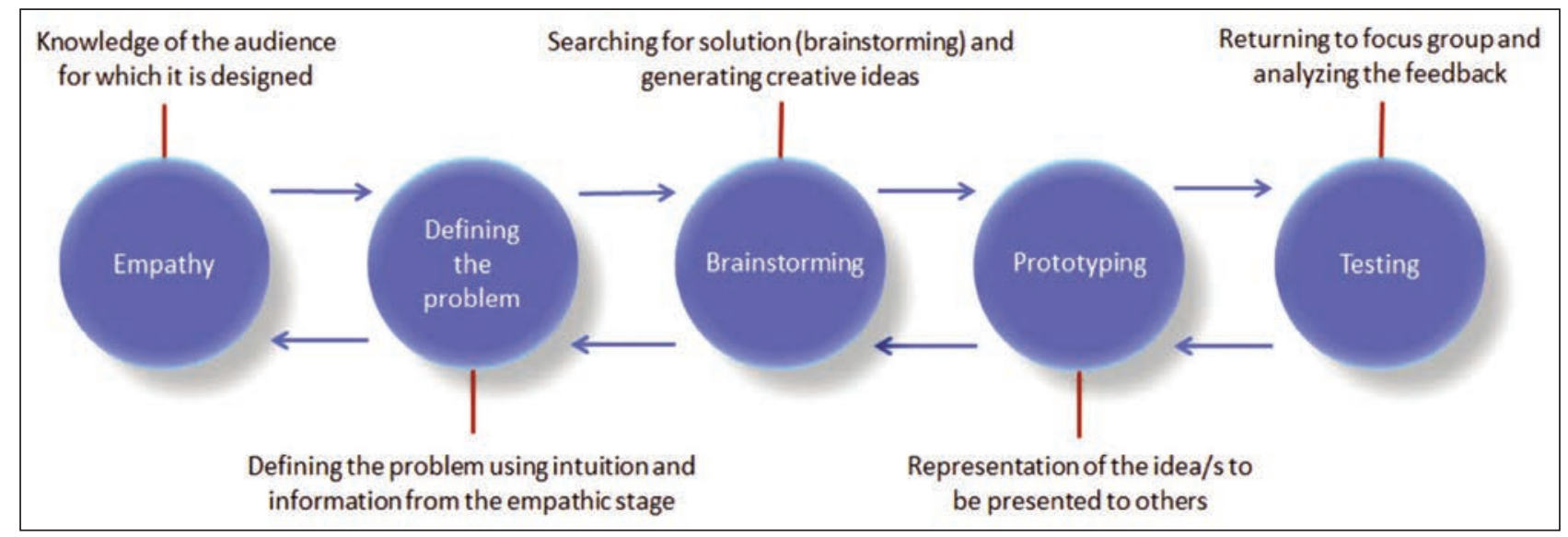

Fig. 1. Design Process Scheme [8] 


\begin{tabular}{|c|c|c|c|}
\hline $\begin{array}{l}\text { Problems that } \\
\text { require } \\
\text { complementary } \\
\text { solutions }\end{array}$ & $\begin{array}{c}\text { Starting points } \\
\text { in the designing/ } \\
\text { production } \\
\text { of agro-textile } \\
\text { elements/products }\end{array}$ & $\begin{array}{l}\text { Key functions of } \\
\text { agro-textiles }\end{array}$ & Effects of agro-textile use \\
\hline $\begin{array}{l}\text { - globalization; } \\
\text { - demographic } \\
\text { pressure; } \\
\text { - limiting resources; } \\
\text { - reducing } \\
\text { greenhouse gas } \\
\text { emissions (GHG); } \\
\text { - adaptation to the } \\
\text { anticipated effects } \\
\text { of climate change; } \\
\text { - the extension of } \\
\text { cultivable areas } \\
\text { (mowing, drying, } \\
\text { etc.); } \\
\text { - increasing the } \\
\text { acute, sub-acute } \\
\text { and indirect toxic } \\
\text { effects of the } \\
\text { chemicals used } \\
\text { on individuals and } \\
\text { ecosystems. }\end{array}$ & $\begin{array}{l}\text { - soil type; } \\
\text { - the required limits } \\
\text { of protection; } \\
\text { - climate and } \\
\text { irrigation } \\
\text { requirements. }\end{array}$ & $\begin{array}{l}\text { - wind resistance; } \\
\text { - resistance to } \\
\quad \text { microorganisms; } \\
\text { - light weight; } \\
\text { - resistance to solar } \\
\text { radiation; } \\
\text { - resistance to } \\
\text { ultraviolet radiation; } \\
\text { - long life; } \\
\text { - biodegradability; } \\
\text { - water conservation; } \\
\text { - stable construction; } \\
\text { - elasticity; } \\
\text { - abrasion resistance; } \\
\text { - protective properties. }\end{array}$ & $\begin{array}{l}\text { - improving the quality of agricultural products; } \\
\text { - preventing the growth and spreading of the } \\
\text { weeds; } \\
\text { - reducing the effects due to the climatic changes } \\
\text { (wind, hail, high temperatures); } \\
\text { - reducing heating and cooling costs by } 10-40 \% \\
\text { in a greenhouse, improving the microclimate; } \\
\text { - adjusting the soil temperature; } \\
\text { - reducing the consumption of chemical } \\
\text { substances; } \\
\text { - enhancing the intensive character through } \\
\text { timeliness, production and high quality, with } \\
\text { minimal costs; } \\
\text { - adjusting the humidity in the soil, maintaining } \\
\text { the phytosanitary status; } \\
\text { - reduces soil fertilizer losses; } \\
\text { - reducing soil compaction; } \\
\text { - reducing of root cutting; } \\
\text { - protecting crops against UV radiation; } \\
\text { - protection of workers to chemical substances; } \\
\text { - reducing the amount of work that the worker } \\
\text { must do; } \\
\text { - reducing the 'cocktail' effect of pesticide mixtures; } \\
\text { - raising the awareness of the population } \\
\text { regarding the correct use of pesticides based } \\
\text { on the principle of respect for the environment } \\
\text { and human health and promoting alternative } \\
\text { methods of plant protection. }\end{array}$ \\
\hline
\end{tabular}

Designing, in the case of agro-textiles, is a problem solving approach based on common human technical/scientific skills or knowledge, which starts from understanding and observing the phenomena of the field in which these textile elements/products will be used. Innovation (discovery through empathy - empathy being a way of looking at the world through many other eyes), designing, experimentation and realization are steps that impose a significant order in the process of making agro-textiles (figure 1).

In this sense, the selection of the textile structure/ fibrous composition/technology for the production of agro-textiles, it is made taking into account the requirements of the domain of use based on a logical matrix regarding the interactions between the problems that need to be solved, the elements that can influence the studied phenomenon, the functions that must be fulfilled by the designed product and the effects produced by its use under real conditions of use (table 2).

The choice of the fibrous composition for the yarns intended for the realization of the textile structures (fabric, knit, non-woven) is a distinct step of the conceptual design, result of the correlation of the requirements of use with the characteristics of the fibers/yarns and not lastly with the specific of the processing technologies.
The fibers/yarns used for the production of agro-textiles must ensure certain functionalities of the final product (table 3) [9].

Table 3

\begin{tabular}{|l|l|}
\hline \multicolumn{2}{|c|}{$\begin{array}{c}\text { CORRESPONDENCE REQUIREMENTS } \\
\text { OF FIBER-PRODUCT/AGRO-TEXTILE }\end{array}$} \\
\hline $\begin{array}{c}\text { Fiber characteristic - } \\
\text { "required" }\end{array}$ & $\begin{array}{l}\text { Agro-textile characteristic - } \\
\text { "expected" }\end{array}$ \\
\hline $\begin{array}{l}\text { Resistance and elongation } \\
\text { at break }\end{array}$ & $\begin{array}{l}\text { Long-term sustainability and } \\
\text { service life }\end{array}$ \\
\hline $\begin{array}{l}\text { Resistance to solar } \\
\text { radiation }\end{array}$ & $\begin{array}{l}\text { Long-term sustainability and } \\
\text { service life }\end{array}$ \\
\hline $\begin{array}{l}\text { Resistance to ultraviolet } \\
\text { radiation }\end{array}$ & $\begin{array}{l}\text { Light permeability between } \\
80-90 \%\end{array}$ \\
\hline Biodegradability & Biodegradation in nature \\
\hline Abrasion resistance & $\begin{array}{l}\text { Long-term sustainability and } \\
\text { service life }\end{array}$ \\
\hline $\begin{array}{l}\text { Resistance to } \\
\text { microorganisms }\end{array}$ & $\begin{array}{l}\text { Resistance to } \\
\text { microorganisms to protect } \\
\text { the living being }\end{array}$ \\
\hline Dimensional stability & $\begin{array}{l}\text { Stability regardless of } \\
\text { application }\end{array}$ \\
\hline Light weight & Easy to use \\
\hline $\begin{array}{l}\text { Resistance to toxic agents } \\
\text { in the environment }\end{array}$ & $\begin{array}{l}\text { Long-term sustainability and } \\
\text { service life }\end{array}$ \\
\hline
\end{tabular}




\section{CONCLUSIONS}

At the planetary level, governments and international bodies are looking for solutions and thinking strategies for the global problems of humanity: food security, climate change, excessive dependence on non-renewable resources, job creation, sustainable economic growth, etc.

The national economy is an extremely complex system requiring the study of economic and social phenomena in a systemic vision as a whole of their interdependencies.

The need for new products, with multiple functionalities, capable of balancing the economic, social and environmental needs, must receive the answers based on a new way of thinking - putting in the same concept human needs, technological resources and constraints, establishing the link between knowledge, processes/technologies and the requirements of the field of use.

The design, in the case of agro-textiles, is an approach to solving problems, based on common human technical/scientific knowledge or skills, which starts from understanding and observing the phenomena of the field in which these textile elements/products will be used. Innovation (discovery through empathy-empathy being a way of looking at the world through many other eyes), designing, experimentation and realization are steps that impose a significant order in the process of making agro-textiles.

The basic characteristics imposed on agro-textiles are:

- Resistance to solar radiation;

- Weatherproof;

- Biodegradation capacity;

- Tensile strength;

- Resistance to ultraviolet radiation;

- High water retention potential;

- Protection properties;

- Light-weight;

- Stable construction, easy to handle.

Agro-textiles are part of the group of complementary, innovative solutions, which can be used in the agricultural field in order to find a balance of the interaction between four systems: economic, human, environmental and technological, in a dynamic and flexible functional process.

\section{ACKNOWLEDGEMENT}

This work was supported by a grant of the Romanian Research and Innovation Ministry, through Sectorial Plan, contract no. 1PS/2019.

\section{REFERENCES}

[1] Roland Berger strategy consultants based on World Bank, OECD, IMF, UNCTAD, EC, UNEP, UNESCO statistics and others - also related to EU documents (EU2020, Lund declaration)

[2] King, P., Green issues - red alert? - Interview with the Chairman of the Nobel Peace Prize winning IPCC (Intergovernmental Panel on Climate Change), In: NATO Review, 2007

[3] Unguru, M., Către o strategie inteligentă pentru agricultură din perspectiva schimbărilor climatice, In: Impactul transformărilor socio-economice și tehnologice la nivel naţional, european și mondial, 2015, 10, 181-192, https://ssrn.com/abstract $=2780327$

[4] Ministerul Agriculturii şi Dezvoltării Rurale, Mediu și schimbări climatice care influențează dezvoltarea rurală, In: Publicaţia Tematică 2014, 9, II

[5] Comisia Europeană, Bugetul UE: politica agricolă comună după 2020, 1 lunie 2018, http://europa.eu/rapid/pressrelease_IP-18-3985_ro.pdf

[6] Chowdhury, J., Nasrin, S., Al Faruque, A., Significance of Agro-Textiles and Future Prospects in Bangladesh, In: European Scientific Journal, 2017, 13, 21 ISSN: 1857-7881, http://dx.doi.org/10.19044/esj.2017.v13n21p139

[7] Sunil, Agrawal,K., Application of textile in agriculture, In: JARSE, 2013, 2, 7, SSN-2319-8354(E)

[8] Pop, T., Design-ul contemporan în fața schimbării paradigmei: gândirea de design, In: Sesiunea de comunicări științifice 2013 "Tendințe în artele vizuale - de la tradiție la experiment" - UNAB 2013, http://dx.doi.org/ 10.13140/2.1.1419.5845

[9] Palamutcu, S., Devrent, N., Technical textiles for agricultural applications, In: International Interdisciplinary Journal of Scientific Research, 2017, 3, 1

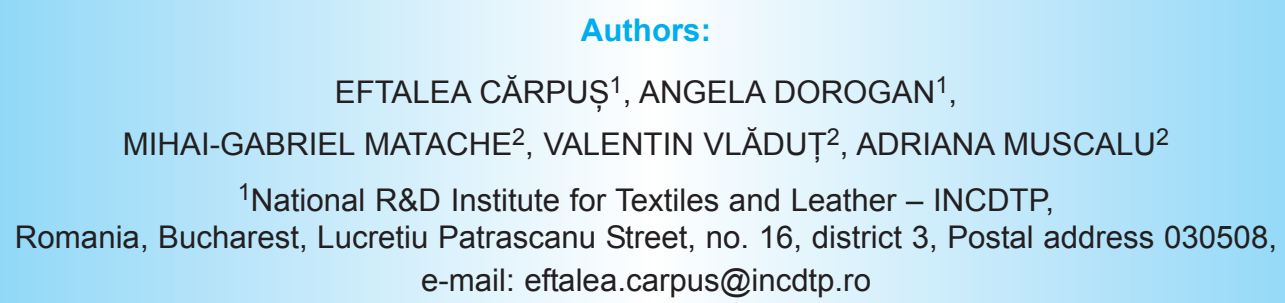

${ }^{2}$ National R\&D Institute for Machines and Installations Designed to Agriculture and Food Industry - INMA, Romania, Bucharest, Ion Ionescu de la Brad Street, no. 6, district 1

e-mail: gabimatache@yahoo.com

Corresponding author:

EFTALEA CĂRPUȘ

e-mail: eftalea.carpus@incdtp.ro 


\title{
The study of 3Rs - Reuse, Repair, and Redesign at Swedish recycling mall
}

\author{
DOI: 10.35530/IT.070.06.1554
}

MANOJ KUMAR PARAS
LARS HEDEGÅRD
ANTONELA CURTEZA

\author{
RUDRAJEET PAL \\ YAN CHEN \\ LICHUAN WANG
}

\section{ABSTRACT - REZUMAT}

The study of 3Rs - Reuse, Repair, and Redesign at Swedish recycling mall

The shopping mall concept has emerged to provide unique mall facets to satisfy consumers that search for the ultimate shopping experience. Under one roof different sellers are assembled together with food outlets and entertainment to fulfill the requirements of consumers. Gradually an awareness of over-consumption has risen together which calls for reuse activities that reduce the consumption of new products. As an answer to the concept of a mall for sustainable practice, a recycling mall has been developed in Eskilstuna, Sweden. This study has been undertaken to understand the practice of the recycling mall and its encompassing reverse value chain activities. This is primarily done in two phases i.e., first to understand the backend operations by visiting collecting and sorting facilities and secondly to comprehend the perspectives of the management team by interviewing them. The findings from the current study suggest that the unique concept of recycling mall create a positive awareness among the customers to reuse, repair and redesign used products. An individual gets a unique experience to donate and purchase clothes, sports equipment, and construction material under one roof.

Keywords: upcycling, redesign, reuse, repair, clothes

\section{Studiul celor 3R - Reutilizare, Reparare și Reproiectare în centrele de recilare din Suedia}

Conceptul de centru pentru cumpărături a apărut pentru a oferi aspecte unice cu scopul de a satisface consumatorii care caută experiența de cumpărături de cea mai bună calitate. Sub același acoperiș, diferiți comercianți sunt grupați cu magazinele alimentare și de divertisment pentru a satisface cerințele consumatorilor. Treptat, a crescut conștientizarea în ceea ce privește supraconsumul, ceea ce necesită activități de reutilizare, care reduc consumul de produse noi. Ca răspuns la conceptul de centru pentru o practică durabilă, un centru de reciclare a fost dezvoltat în Eskilstuna, Suedia. Acest studiu a fost întreprins pentru a înțelege practicile centrului de reciclare și ale activităților sale din lanțul valoric invers. Acesta se realizează în două faze, în primul rând pentru a înțelege operațiunile de backend vizitând unitățile de colectare și sortare și în al doilea rând pentru a înțelege perspectivele echipei de management, prin intervievarea acesteia. Rezultatele studiului sugerează că acest concept de centru de reciclare creează o conștientizare pozitivă a clienților de a reutiliza, repara și reproiecta produsele folosite. O persoană dobândește o experiență unică prin donarea și achiziționarea articolelor de îmbrăcăminte, echipamentelor sportive și materialelor de construcție sub un singur acoperiș.

Cuvinte-cheie: reciclare, reproiectare, reutilizare, reparare, articole de îmbrăcăminte

\section{INTRODUCTION}

Reuse is considered to be one of the most common ways to achieve sustainability in the clothing value chain [1]. 'Reuse' is a process to extend the life of a clothing product by acquiring the products after the end of use or end of life [2]. The reuse can minimize the entry of new products and thus, reduce the environmental impacts [3-4]. The products which are not suitable for direct reuse can be recycled to extract fibres or transformed into rags, wipers, and insulating material [5-9]. The reuse based clothing value chain consists of collection, sorting, and reprocessing. The collection is a process to acquire an end of use or end of life products, whereas sorting and grading operation involves categorization of acquired products according to their condition $[5,7,10]$. The sorted and graded products can be reprocessed such as repair, redesign [11] and washed to improve the aesthetic and/or functional value [7].

Informal exchange of clothes is an old phenomenon between friends and family, however, a formal model has been designed to recover used products[12]. In most of Western Europe and North American countries, the used clothes collection is carried out by charities [13]; whereas the collection of paper, plastic, and glass is performed by the for-profit organization [3]. The collection channel driven by the producer is better than the third party collector [14]. Easy accessibility to collection sites such as near city centre, gas station, housing area is significantly important for consumers to discard useful products for reuse [15-18]. Sorting is the categorization process to provide acquired products with a different path such as direct reuse, recycle or waste stream for the incineration [19]. The used clothes are fractioned into 
superior quality for the domestic market, inferior quality for export, and unwearable quality to repurposed into rags and wipers [5]. The sorting and categorization process for textile and clothing is complex due to the enormous variance of fabric material and its construction into clothes $[5,8]$. The sorting process can be optimized by removal of waste and unwanted products from reverse value chain [20]. This can be achieved by concurrent collection and sorting process [21]. The cost efficiency in sorting process can be achieved by offshoring sorting and grading activities to the developing countries. The functional and aesthetic value of products can be restored or improved by repair, redesign and laundry activities [1, 22-23]. The skill and technical knowledge influence the reprocessing activities [5, 7]. The recycling mall strategy to promote the reuse, repair, and redesign is novel. The purpose of this paper is to understand the management of unique concept of recycling mall based on the reuse-based reverse value chain.

\section{METHOD}

The qualitative method was adopted to perform the research considering its relevance and appropriateness to study inter-organizational relationships. The phenomena of reuse, repair, and recycling of used clothes have been studied at the Swedish recycling mall. Through telephonic discussion and exchange of emails, researchers have able to establish a relationship with mall manager. This provided better access and participation of organization in the research process. Access to personnel and facilities of an organization improved quality of data. Data has been collected from multiple sources within the firm [24].

Data collection for this research has started by reading newspaper articles, reports to understand the unique phenomena of recycling mall. Prior to the visit to the recycling mall, websites of the mall and news reports available on different websites were thoroughly explored. During the visit, in-depth face to face interview was carried out with the mall manager. The interview lasted for more than one hour. The researcher has made a visit to different sections of the mall. Direct observation helped us to understand the process in details. Mall manager guided around different processes involved. One of the researchers is a native speaker of the language spoken by the employee of the recycling mall. This helps us to collect minute information perfectly from various persons in the organization. Follow up interviews were undertaken to strengthen the analysis. During the analysis phase, different logical tools like table, charts and figure were made to understand the trends and phenomena. NVivo 10 was used to analyze the interviews and other collected information. Interviews transcript were systematically analyzed to find out themes, ideas, patterns, concepts to understand the process of recycling mall [25].

\section{FINDINGS}

The Recycling mall is Sweden's - and perhaps the world's - first shopping centre with shops that give used things new life by repairing, transforming and selling. This mall is situated in Eskilstuna Municipality in Södermanl and County in southeast Sweden. The mall was started in August 2015. Currently, the recycling mall is functioned in the $5000 \mathrm{~m}^{2}$ area that can be extended to $15000 \mathrm{~m}^{2}$. At present, the rentable area is $3000 \mathrm{~m}^{2}$. There are four clothes stores. The first clothes store is for high-quality second hand clothes and most of the clothes are for kids. The second store is second hand cloth store that washes and irons the clothes before selling it. The third store is owned by Stockholm based charity organization and this is a normal second hand cloth stores. The fourth store is a safety kids stores that sell second hand products and safety clothes for kids. The other Second hand Stores are for sports and bicycles, building materials, computer and electronics products, furniture and households items.

In the recycling mall, there are other facilities such as redesigning lab for the vocational training school, conference rooms, and cafeteria. A restaurant and café are under construction and are expected to be open soon. In the mall, two conference rooms are also under construction. The bigger one is for 100 guests and the smaller one for 30 guests. The conferences are hosted by internal and external clients, but the majority of conferences are hosted by internal customers. The bigger conference room is also used as an event area and at the time of the observation, a change-your-toys-event was planned to the following Saturday. The vocational school associated with recycling mall has 16 students and offers a one-year program in re-design. The students work with paper, plastic and furniture. An example of a current project that the student worked with was the design of a hotel lobby. The reverse value chain process of recycling mall is depicted in the below figure 1.

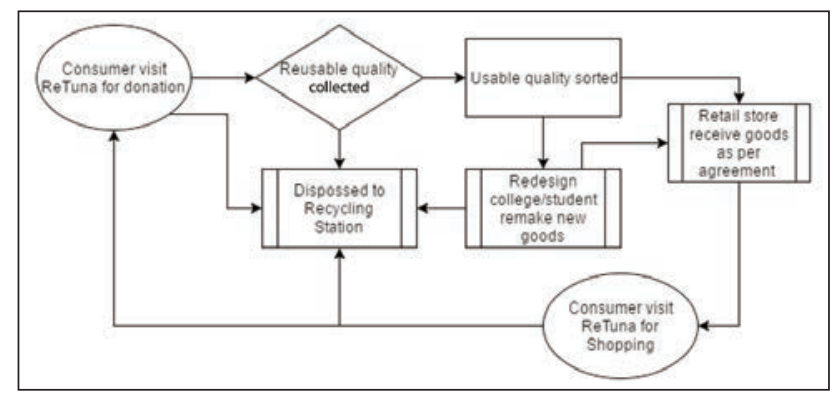

Fig. 1. Process at recycling mall

Below are the details of collection, sorting and reprocessing activities done at the recycling mall.

\section{Collection}

The mall is situated along with a waste recycling station and has a collection area on the ground floor for individual residents. The mall does not accept industrial waste. A person can drive to the mall to drop 
unwanted stuff. There are total two gates which accept the donation. A third gate is meant for different kinds of hazardous products. The gate no 2 is opened in winter while gate no 3 is for summer for all kind of items. Mall accepts all kind of items including textiles and furniture. Apart from the in-house collection, the organization has two collection bins located at waste recycling stations in Eskilstuna and Stragnas. Goods are delivered from these external collection centers once a week in peak time and once a month at low season. The stores are not allowed to receive direct donation in-store (exception-high fashion clothing store) since the mall does not want to have any trade activities and risk of black money. The high fashion clothing shop is allowed to collect items in the mall since they already had that service before they moved into the mall. It is a part of their business agreement to collect clothes. Another clothing shop tries to establish collaborations with fashion retail companies to place collection bins at their retail stores, this will able help companies to collect highquality clothes. Adjacent to the Mall, there is recycling station where one can drop all kind of waste (which cannot be reused). In total, the recycling stations are visited by around 400 cars each day. The policy of the mall is to accept all goods that an inhabitant offers for donation, but according to the mall manager, she has got information that the sorting staff in some cases tells the individual that the goods are unwanted and refer them to the waste recycling station.

\section{Sorting}

There are total six people working in the collection and warehouse and they are hired by Eskilstuna municipality. They are either physically challenged persons or suffer from another kind of disability. After receiving the donation, they sort the items in the relevant section of each shop. The Shops person then can come and sort items according to their requirements in the section, but they are not supposed to look into the unsorted donations. The Mall manager had made a list of items meant for different shops as per their agreement. Those lists are revised by the mall manager from time to time. The revision will be done in collaboration with the shops and those who work with the sorting. The school receives goods from the warehouse. The school also has a list, but in addition to this standard list, the students and teacher give a weekly list with the desired object depending on their current work. The School is offered all other goods that none of the other shops wants, an example form the observation was an old piano. Mostly textile based unique collection is offered to training schools. The students show their creativity on unwanted used items.

The inflow of goods to the sorting station varies from day to day and in some periods there are too many goods to care of for the shops. Since the flow is important due to the limited area for storage the mall offers the goods to charity organizations and different churches. The last option is disposing off to the recycling station, something that they try to avoid but sometimes it is necessary as per mall manager. In the beginning, the shops were gentle with each other and took everything that was offered. After three/four months the shops are more careful and it is a bit of competition about the goods. The clothes are first offered to the high fashion shop according to the earlier agreement. All clothes are therefore placed in their area and the staff at that shop will sort it. If it is children clothes it will be placed in the area of the kid's shops. If there are lots of clothes, the staff will not sort it piece by piece, instead, they will divide the plastic bags. At present, the recycling mall does not have data about the goods that are collected and how much goods are sorted per day. Through the sorting, the staffs of the recycling mall have started to know what kind of products each shop wants.

\section{Reprocessing}

Design laboratory for student located inside the recycling mall is the only place that is doing reprocessing or redesign activity on collected textile materials. However, children clothing shop has washing and ironing facility and the space to perform minor processing. Remaining all other shops sells collected goods without performing value addition. High fashion clothing shop washes some items at home. High fashion clothing shop also offers re-designed baby clothes and re-designed hood for strollers. One stroller hood cost between 1000-15000 SEK. The mall manager has great vision in increasing value addition on old products. On 5 years down, mall has planned to sell clothes at an average price of 300 SEK.

\section{DISCUSSION}

The reverse value chains of clothes are influenced by different factors. Paras et al. [20] have identified different factors such as business system, awareness and value creation. Some of the factors have been found relevant to the recycling mall study are discussed as follows:

Business process design: The recycling mall seems to have an excellent business plan. Facilities, as well as vision for the business, are unique and excellent. A municipality-owned company (Eskilstuna Strängnäsenergiochmiljö) owns the recycling mall. The core business for Eskilstuna Strängäsenergiochmiljö is waste management and electricity generation. The whole infrastructure is also owned by the municipality company and the recycling mall hires the area that is needed for the mall. Parts of the total area are then leased to privately owned companies such as charity organizations, social businesses and for-profit shops. The recycling mall is the facilitator for the all second hand stores. Stores are supposed to pay 1400 SEK $/ \mathrm{m}^{2}$ annually. During 2015 and 2016 there was $50 \%$ discount on rent. Beside this, shops are supposed to pay for other services on their own, for example, electricity and internet. The rent cost 
includes the space as well as second hand goods, so the shops pay for both space/area and goods.

During the first two years (2015 and 2016) the municipality gives the recycling mall a subsidy (2.5 million SEK per year) but from 2017 there was a plan to make the recycling mall economically independent. However, the mall is supposed to function by own from 2017 and will get only 50,000 SEK grant from the municipality. So they are looking for a private player like IKEA, H\&M to open recycle or reuse store in the mall. Some of the shops also offered new products, but in this case, the items have to be friendly in some way to be accepted by the mall. The newly produced products may not be a major part of the shop's assortment. Before a shop is allowed to establish in the mall, the business plan of the shop is examined and it is important that the shop has a business perspective of reuse and make a profit out of used products. In this process, the shop representative and the mall manager also discuss and agree on the kind of products the shop shall receive.

Value creation: Focus has been given to givea new look of the old and discarded product. The vocational training school is doing huge efforts to redesign old products.

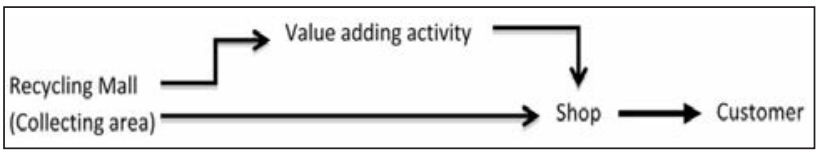

Fig. 2. The process of value addition

Value addition on the old product is a prime focus area for the mall and in the future ambition is that the shops do some value addition on the collected goods. Discarded product seems to be having zero value for consumers without any value addition. Each shop decides the price for the products they sell. At present, clothing product is sold at the average price of 100 SEK. Most of the individual donates good quality clothes. However, they are not keen on purchasing clothes from the mall. They will always criticize the price in spite the price is much lower in the mall shops.

Information: Reaching to people is the prime concern. The financial limitation is found to be the main hindrance in advertisements. Table 1 represents the methods that are followed by the mall to reach to the consumer.

Table 1

\begin{tabular}{|l|}
\hline \multicolumn{1}{|c|}{ ADVERTISEMENT METHODS } \\
\hline Local newspaper advertisement \\
Local broadcast campaigns \\
Social media like Facebook, Instagram and Twitter \\
Inviting students and other people to visit the mall \\
\hline
\end{tabular}

The advertisement is mainly focused on the consumers to raise the awareness of reuse, recycling and the mall. The advertisement budget is currently 50,000 SEK a year so most of the work is done by the mall manager. The owner company (Eskilstuna Strängnäsenerigochmiljö) has an information department that helps the mall a bit, for example with the homepage and social media, but long-term view of the department is that the mall shall manage its own business.

Initially, the mall had the campaign to invite shops in the region, but the budget for that campaign is utilized and the mall will have less money in the future for that kind of campaigns. There have been mostly positive reactions from consumers, companies in the city and other stakeholders. Individual consumers have complained that some products are missing in the mall, but negative comments have been few. The mall manager describes that when a customer visits the mall for the first time often experience a feeling of surprise. The mall manager thinks that they need to improve and expand the communication and advertisements in the future to be successful. She says that "if you shall be a real mall, people must be able to hear you."

\section{CONCLUSION}

The study shows that the recycling mall has been established near a recycling centre to promote the concept of reuse. Instead of disposing of goods to incineration, individuals are encouraged to donate the goods to the mall. The collected products are sorted on the basis of type by mall employees and kept at the different designated location of each tenant of recycling mall in line with their contract. Employees of the tenants visit the warehouse to receive and sort their assigned goods according to conditions and product categories. Some of the tenants have facilities to re-design, repair and wash the garments to improve the functionality of products. The mall management is doing efforts to increase the number of upcycling activities that the tenants perform to increase the value of the reused goods. The reuse mall also provides workshop and laboratory space to the college involved in the education of reuse and re-design. Students of the college experiment with donated goods to redesign new products. Still, redesign practice at the mall is in its initial phases, recycling mall is indeed a revolutionary concept to enhance the practice of reuse. Future research can study the scope of recycling mall across different geographical locations.

\section{ACKNOWLEDGEMENTS}

This research has been done under Erasmus Mundus joint doctoral program (SMDTex), which is financed by European Union. 


\section{REFERENCES}

[1] Paras, M.K., Pal, R., Ekwall, D., Systematic literature review to develop a conceptual framework for a reuse-based clothing value chain, In: The International Review of Retail, Distribution and Consumer Research, 2017, 1-28

[2] Dervojeda, K., et al., Clean technologies circular supply chains, In: EU report, 2014, 248-274

[3] Woolridge, A.C., et al., Life cycle assessment for reuse/recycling of donated waste textiles compared to use of virgin material: An UK energy saving perspective, In:Resources, Conservation \& Recycling, 2006, 46, 1, 94-103

[4] Farrant, L., Olsen, S.I., Wangel, A., Environmental benefits from reusing clothes, In: The International Journal of Life Cycle Assessment, 2010, 15, 7, 726-736

[5] Hawley, J.M., Digging for Diamonds: A Conceptual Framework for Understanding Reclaimed Textile Products, In: Clothing and Textiles Research Journal, 2006, 24, 3, 262-275

[6] Morley, N., Bartlett, C., McGill, I., Maximising reuse and recycling of UK clothing and textiles: $A$ report to the department for environment, Food and rural affairs, Oakdene Hollins Ltd, 2009

[7] Abraham, N., The apparel aftermarket in India-a case study focusing on reverse logistics, In: Journal of Fashion Marketing and Management: An International Journal, 2011, 15, 2, 211-227

[8] Botticello, J., Between classification, objectification, and perception: processing secondhand clothing for recycling and reuse, In: Textile, 2012, 10, 2, 164-183

[9] Ekström, K.M., Salomonson, N., Reuse and Recycling of Clothing and Textiles - A Network Approach, In: Journal of Macromarketing, 2014, 34, 3, 383-399

[10] Rogers, D.S., Tibben-Lembke, R., An examination of reverse logistics practices, In: Journal of Business Logistics, 2001, 22, 2, 129-148

[11] Cuc, S., Tripa, S., Redesign and upcycling-a solution for the competitiveness of small and medium-sized enterprises in the clothing industry, In: Industria Textila, 2018, 69, 1, 31-36, https://doi.org/10.35530/IT.069.01.1417

[12] Besiou, M., Georgiadis, P, Van Wassenhove, L.N., Official recycling and scavengers: Symbiotic or conflicting? In: European Journal of Operational Research, 2012, 218, 2, 563-576

[13] Tojo, N., et al., Prevention of Textile Waste - Material flows of textiles in three Nordic countries and suggestions on policy instruments, In: TemaNord 2012, Nordic Council of Ministers: Copenhagen

[14] Chan, T.Y., Wong, C.W.Y., The consumption side of sustainable fashion supply chain, In: Journal of Fashion Marketing and Management: An International Journal, 2012, 16, 2, 193-215

[15] Min, H., Ko, C.S., Ko, H.J., The spatial and temporal consolidation of returned products in a closed-loop supply chain network, In: Computers \& Industrial Engineering, 2006, 51, 2, 309-320

[16] Ha-Brookshire, J.E., Hodges, N.N., Socially Responsible Consumer Behavior?: Exploring Used Clothing Donation Behavior, In: Clothing and Textiles Research Journal, 2009, 27, 3, 179-196

[17] Morgan, L.R., Birtwistle, G., An investigation of young fashion consumers' disposal habits, In: International journal of consumer studies, 2009, 33, 2, 190-198

[18] Goldsmith, D., The Worn, the torn, the wearable: Textile recycling in union square, In: Nordic Textile Journal, 2012, 1, 16-29

[19] Jayaraman, V., Ross, A.D., Agarwal, A., Role of information technology and collaboration in reverse logistics supply chains, In: International Journal of Logistics: Research and Applications, 2008, 11, 6, 409-425

[20] Paras, M.K., et al., An Exploratory Study of Swedish Charities to Develop a Model for the Reuse-Based Clothing Value Chain, In: Sustainability, 2018, 10, 4, 1176

[21] Moise, M., The importance of reverse logistics for retail activity, In: The Amfiteatru Economic journal, 2008, 10, 24, 192-209

[22] Paras, M.K., Curteza, A., Revisiting upcycling phenomena: a concept in clothing industry, In: Research Journal of Textile and Apparel, 2018, 22, 1, 46-58

[23] Paras, M.K., Pal, R., Application of Markov chain for LCA: A study on the clothes 'reuse' in Nordic countries, In: Int. J. Adv. Manuf. Technol., 2018, 94, 191-201

[24] Yin, R.K., Case study research: Design and methods, SAGE publications, 2013

[25] Czarniawska, B., Social Science Research: From Field to Desk, SAGE Publications, 2014

\section{Authors:}

\section{MANOJ KUMAR PARAS ${ }^{1,2,3}$, LARS HEDEGÅRD ${ }^{3}$, ANTONELA CURTEZA ${ }^{2}$ RUDRAJEET PAL ${ }^{3}$, YAN CHEN ${ }^{1}$, LICHUAN WANG ${ }^{1}$}

${ }^{1}$ College of Textile and Clothing Engineering, Soochow University, Suzhou 215006, China

2"Gheorghe Asachi" Technical University of lasi, Bulevardul Profesor Dimitrie Mangeron 67, lasi, 700050, Romania

${ }^{3}$ Faculty of Textiles, Engineering and Business, University of Borås, Allégatan 1, 50139032 Borås, Sweden

\section{Corresponding author:}

LICHUAN WANG

e-mail: Lcwang@suda.edu.cn 


\section{Computer aided design of knitted and woven fabrics and virtual garment simulation}

DOI: $10.35530 / 1 T .070 .06 .1659$

INDRIE LILIANA

MEHMET METE MUTLU

NILAY ORK EFENDIOGLU
TRIPA SIMONA

PABLO DIAZ GARCIA

MIQUEL SOLER

\section{ABSTRACT - REZUMAT}

\section{Computer aided design of knitted and woven fabrics and virtual garment simulation}

Pattern cutting, sizing and fit are major issues for the clothing brands. All fashion companies are interested on how the product will fit their target customers and this involves making samples that eventually will not look or fit as per the desired design. 3D technology solutions are truly the best to deal with the existing needs of clothing manufacturers in order to diminish the costs and time of the sampling process, to improve the quality and reduce the rejects. In this study, the authors used automation techniques like computer pattern design, computer aided fabric production and $3 D$ Simulation software. Two different fabrics (woven and knitted) were designed and produced. Then their material properties which have to be known by the 3D simulation were determined by official and in-house standards. Finally, 3D visualizations of dresses were created by using pattern and material data of the fabrics. By this study we were able to explain the product development route, from fabric design to garment prototype by using computers, for the companies willing to benefit from the advantages of computer aided design and manufacture.

Keywords: 3D, garment design, garment simulation, woven fabric, knitted fabric.

Proiectarea asistată de calculator a țesăturilor și tricoturilor și simularea în spațiul virtual a îmbrăcămintei

Realizarea tiparelor, stabilirea gamei dimensionale și modul de așezare a produselor pe corpul purtătorilor sunt probleme majore cu care se confruntă firmele producătoare de îmbrăcăminte. Toate companiile de modă sunt interesate de modul în care produsele de îmbrăcăminte sunt adaptate la cerinţele consumatorilor, iar acest lucru implică realizarea de mostre care, la final, s-ar putea să nu arate conform design-ului dorit. În sprijinul producătorilor de îmbrăcăminte vin soluțiile tehnologice $3 D$ care au ca scop diminuarea costurilor și a timpului procesului de eșantionare, îmbunătătirea calității produselor şi eliminarea produselor neconforme (refuzate). În acestă lucrare, autorii au utilizat tehnici de automatizare precum designul materialelor, producerea acestora şi simularea 3D a îmbrăcămintei. Două materiale diferite (țesute și tricotate) au fost proiectate și produse. Apoi au fost determinate proprietățile acestora, proprietăți care, alături de tipare, au fost utilizate pentru realizarea simulării 3D a rochiilor. De asemenea, pentru companiile care doresc să beneficieze de avantajele proiectării și fabricării asistate de calculator, a fost prezentat modulvoltare a unui produs de la proiectarea asistată de calculator a materialelor la prototipul îmbrăcămintei.

Cuvinte-cheie: $3 D$, design vestimentar, simularea îmbrăcămintei, țesătură, tricot

\section{INTRODUCTION}

In front of increasingly demanding consumers, who expect variety, low prices and quality products, the CAD/CAM programs (such as 2D patternmaking and $3 \mathrm{D}$ clothing design and modeling) can improve the flexibility in design, productivity and speed to market [1]. According to garment manufacturers and fashion retailers, the pattern cutting, sizing and fit are major issues for the clothing brands. All fashion companies are interested on how the product will fit their target customers and this involves making samples that eventually will not look or fit as per the desired design [2]. Power J. considers that the product development time can go to $70 \%$ in a typical garment life cycle, while the actual manufacture is $30 \%$ [3]. 3D technology solutions are truly the best to deal with the existing needs of clothing manufacturers in order to diminish the costs and time of the sampling process, to improve the quality and reduce the rejects [2].

Virtual garment design and 3D simulation [4-11] have to take into account not only the physical characteristics of the fabric (density, thickness, deformability) but also it has to combine a large spectrum of techniques such as mechanical simulation, collision detection, and user interface techniques for creating garments. The virtual prototyping can be successful only when all specific characteristics of the textile materials and accurate virtual body models to simulate the garment fit are fully taken into account [12]. Assyst Vidya 3D [13] is a leading software for the 3D simulation of apparel and enables the visualization and simulation of collections, with correct body dimension data, original CAD designs and real material parameters. It simulates persons with realistic 
body measurements, volume and movement behavior. It also uses real material parameters, allowing the natural stretch behavior and the structure of a fabric to be checked on the screen. Drape, elasticity and structure correspond to the fabric's natural movement behavior Human, pattern and material interact perfectly for the simulation and the same body measurements/size tables are used in CAD and for the creation of avatars. The simulated $3 D$ garment consists of the sewn 2D CAD pattern pieces, just like in real life.

The first step in our paper was to generate the Argyle pattern designs in Adobe Illustrator. After the design part, the second step was to realize the woven and the knitted fabrics. The woven and knitted samples were produced on a SMIT Textile GS900 Jacquard Loom respectively on a Shima Seiki Knittingmachine. The designs were transposed in these two types of fabrics because the computer-aided woven fabric design has been the first topic in the automation in textile industry [14]. It has been developed to be one of the most effective processes nowadays, meanwhile it is possible to create products through knitting with outstanding characteristics, such as: knitting to shape, great flexibility in production, controlled properties, and excellent formability [15]. The second step was to determine the properties of knitted and woven fabrics (Thickness, Grammage, Stretching, Bending, and Friction) and to convert them to Vidya 3D Software parameters. Simulations were done by using Human Solutions Assyst Vidya 3D software version 20.17.2.31690. The garment was fitted on a virtual mannequin in order to visualize the draping of the knitted and woven fabrics before the manufacturing. The data collected were used as input for material wizard parameters. In addition, the photos of the fabric were taken and their texture was transferred to the software for realistic visualization. The final step was to make the real prototype of woman's dress according to the real body measurement for size 38 . The aim of the study was to make a lab-scale production to explain automation techniques like computer pattern design, computer aided fabric production and 3D simulation software in an apparel product development route. For this purpose, two different kinds of fabrics (woven and knitted) were designed and produced. The material properties required for the 3D simulation software were determined by using various standard and in-house test methods. The measured material data were interpreted to the $3 D$ software considering behaviors of the clothes in the visualization and 3D prototypes of clothes by these materials were obtained. The detailed explanation of methodology will be beneficial for the companies who are going to implement computer aided design and manufacturing into their manufacturing line.

\section{MATERIALS AND METHODS}

\section{Argyle pattern designs}

Taking into account the fashion trends, in the present paper the authors intended to create different Argyle

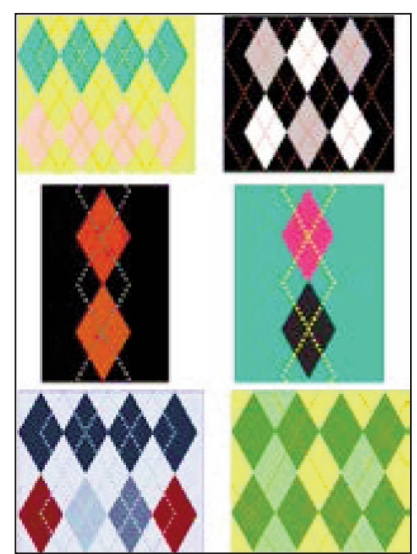

Fig. 1. Argyle Patterns in Adobe Illustrator
Patterns designs, using the instruments of Adobe Illustrator (figure 1). Next step was to make the woven and knitted fabrics.

\section{Woven fabric}

The woven fabric has been weaved on a SMIT Textile GS900 Jacquard Loom (figure 2). This is an appropriate loom for a large variety of applications [16], from garment fabrics to home textiles, terry cloths and technical fabrics. Provided with an electronic jacquard machine Stäubli DX-100 of 1.408 hooks, the harnesses are built in straight tie order, which allows the correct ordering of the yarns for interlacing and thus obtaining the required drawing. Regarding the fabric structure, the width of the loom is $160 \mathrm{~cm}$, and the beam is composed by 9,600 threads, with a set of 60 picks $/ \mathrm{cm}$ in the comb. The count of the warp thread used is polyester 17 TEX, in brown colour. The weft is composed by two different yarns with the same count 12.4 TEX, made of polyester fibre, in different colours in relation 1:1, one sky colour multifilament and the other one is white multifilament colour. The fabric has a weft density of 72 picks/cm and the structure of the fabric is double face by weft. This design has been achieved by combining three different weaving types of the fabric, and with the correct combination of colours of the warp and weft threads. To obtain the complete design, the pattern repeats every $11.4 \mathrm{~cm}$.

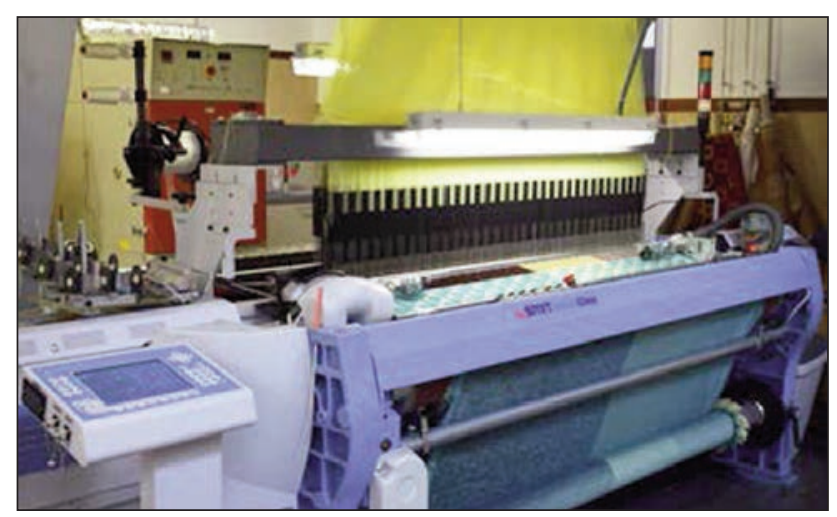

Fig. 2. The fabric made by Smit Textile GS900 Jacquard Loom

\section{Knitted fabric}

The proposed design was transposed into a jacquard knit, made on a Shima Seiki knitting machine. The knits with Jacquard drawings are characterized by large and very large drawings the first step was to decide the size of the pattern or design. Thus, was decided that the drawing ratio should have a width of 
$6 \mathrm{~cm}$ and a height of $24 \mathrm{~cm}$, repeating itself on the entire surface of the knit.

After that was draw on the computer screen, the pattern on a grid, with the help of a specific design program for knitting machines, in which each square will be a stitch (in our case the 'KNIT' program has been used from the manufacturer SHIMA-SEIKI) (figure 3). The design was done drawing in the first phase the ground structure, and on it, the different colours that will form the final drawing are incorporated successively. The colours used for the design are not random, but must be selected from a colour tablet proposed by the software manufacturer, and each colour has a specific meaning. When the stitch design has been completed, the instructions for the machine must be incorporated into the drawing on the screen: speed, take down, yarn feeder used for each colour, stitch quality, cycles, etc.

Once the design is completed and all the commands have been analyzed by the software to detect possible failures, the program generates a file in the machine-language that can be transferred to the knitting machine through a wire from the programming computer, or with the help of an external memory (pen-drive).

After feeding the knitting machine with the yarns used, the actual knitting was performed. The knitwear has a horizontal width of 27 strings $/ 50 \mathrm{~mm}$ and a vertical 25 rows $/ 50 \mathrm{~mm}$, which gives the knitwear the necessary properties to be used in subsequent fabrication of many types of outwear products.

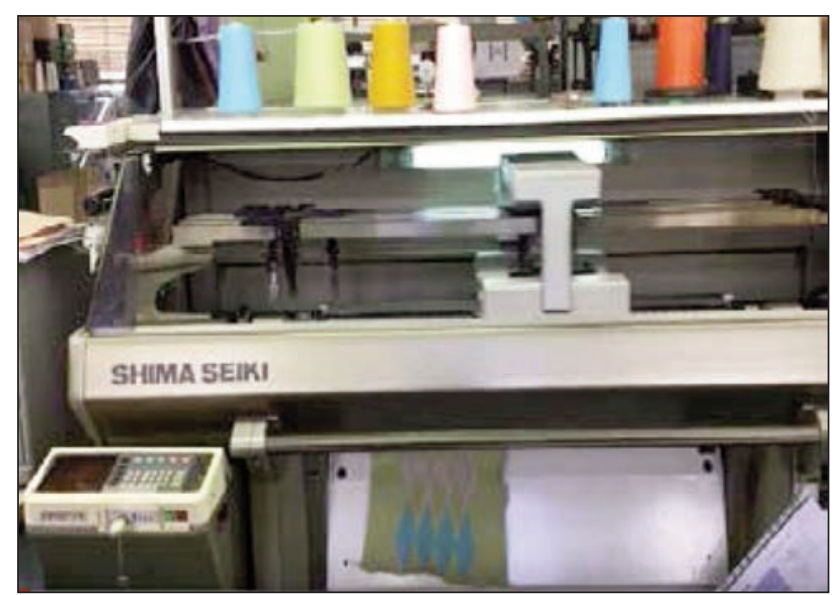

Fig. 3. The knitted fabric made by SHIMA-SEIKI

Determining properties of fabrics and converting them to Vidya 3D Software parameters

Analyzing the mechanical properties can enhance to determine the behaviour of the fabrics during clothing exploitation [17]. Samples of woven fabric and knit obtained were analyzed and subjected to tests that determined the following properties (Thickness, Grammage, Elongation, Bending, and Friction Coefficient).

The thicknesses of test samples were measured by Satra-Thickness gauge according to ISO 2589:2016 (IULTCS/IUP 4standard. The grammage of test samples were measured by Analytical balance according to ISO 3801 standard.

Shimadzu AG-IS Tensile Tester and Trapezium-2 software were used for elongation test according to EN ISO 13934-1 standard. Five samples were taken with the size of $50 \mathrm{~mm} \times 250 \mathrm{~mm}$ per weft, warp and diagonal direction. Clamping width was $50 \mathrm{~mm}$ and clamping length was $200 \mathrm{~mm}$. The test started without any pre-load. Testing speed was $100 \mathrm{~mm} / \mathrm{min}$. In Vidya 3D, to determine the force, the garment fit has to be considered. The closer the garment fits to the body, the higher the value for this parameter. Following forces occur while wearing clothing. Value Explanation: $20 \mathrm{~N} / \mathrm{m}$ : Loose fitting, $40 \mathrm{~N} / \mathrm{m}$ : Tight fitting, $60 \mathrm{~N} / \mathrm{m}$ : Shape wear, $80 \mathrm{~N} / \mathrm{m}$ : Compression wear. Dress model was chosen and thus defined force was selected $20 \mathrm{~N} / \mathrm{m}$. In stress-strain diagram, the elongation at $20 \mathrm{~N} / \mathrm{mm}$ was observed and noted as Elongation \%.

Fabric bending rigidity is one of the most important factors, which has effect on handling, and comfort of apparel; in 1930, the bending behaviour has been explored quite extensively, beginning by Peirce [18]. On the other hand, bending rigidity is one of the most important properties of fabrics and is a key component in deciding fabric handle and drape. It is an important contributor to fabric's formability [19], buckling behaviour [20], wrinkle-resistance [21] and crease resistance [22].

Shirley stiffness tester is used for bending stiffness according to ASTM D1388 standard. The principle of this test is to measure the length of the strip-cut sample with a horizontal angle of $41.5^{\circ}$. The device has a smoothly slippery plate $\mathrm{P}$ on the surface and an $\mathrm{S}$ slider with a rough surface millimeter. Width of $S$ slider is 2.5 centimeters and length is 15 centimeters. In the horizontally placed section of the sample prepared with dimensions of $2.5 \times 15$ centimeters, the sample was allowed to be released from one end while it was allowed to be released by its own weight on the other hand. Observation lines have been drawn on the lateral transparent covers of the device, which pass through the leading edge of the upper plane and make an angle of $41.5^{\circ}$. When the tip of the sample reaches a slope of $41^{\circ}$ below the horizontal, the hanging length is twice the length of the bending length. Bending rigidity was calculated for each sample at the front and back of fabrics. The bending properties of the woven and knitted fabrics govern many aspects of the fabric's performance, such as the hand and drape, and they are an essential part of complex fabrics deformation analysis.

FricTorq device is an improved system for the determination of dynamic friction coefficient. The device is used to determine the dynamic friction coefficient based on the torque of the rotation. For the friction coefficient test, two samples were taken from each sample with the help of the template with the diameter of 13 centimeters. The top plate is removed so that the test sample can be placed in the device. The sample was placed on the centre of the main disc. The sample was compacted onto the main disc by 


\begin{tabular}{|c|c|c|c|c|c|c|}
\hline \multicolumn{7}{|c|}{ THE PROPERTIES OF THE FABRICS } \\
\hline \multirow[b]{2}{*}{ Fabrics } & \multicolumn{3}{|c|}{ Knitted } & \multicolumn{3}{|c|}{ Woven } \\
\hline & & & & & & \\
\hline \multicolumn{7}{|c|}{ Datasheet specifications } \\
\hline Knit type and Weave type & \multicolumn{3}{|c|}{ Jacquard Jersey } & \multicolumn{3}{|c|}{ Plain fabric (Jacquard) } \\
\hline Fibre content & \multicolumn{3}{|c|}{ Acrylic fiber } & \multicolumn{3}{|c|}{ Polyester fiber } \\
\hline Width $(\mathrm{cm})$ & \multicolumn{3}{|c|}{75} & \multicolumn{3}{|c|}{160} \\
\hline Weight $\left(\mathrm{gr} / \mathrm{m}^{2}\right)$ & \multicolumn{3}{|c|}{325.54} & \multicolumn{3}{|c|}{235.90} \\
\hline \multirow[t]{2}{*}{ Thickness (mm) } & \multicolumn{3}{|c|}{1.09} & \multicolumn{3}{|c|}{0.38} \\
\hline & Weft & Warp & Bias & Weft & Warp & Bias \\
\hline Elongation at $20 \mathrm{~N} / \mathrm{m}(\%)$ & 61.2985 & 42.7015 & 39.7565 & 4.09 & 5.1505 & 12.647 \\
\hline Bending (mg.cm) & 443.76 & 625.83 & - & 855.63 & 1247.81 & - \\
\hline Friction Coefficient (Back) & \multicolumn{3}{|c|}{0.65} & \multicolumn{3}{|c|}{0.33} \\
\hline
\end{tabular}

the weight of the press ring itself. Four vertical guides restrict it. The centre disk is placed on the press ring. It must definitely be removed before the start of the test. The contact sensor is placed on the sample so that it enters into the round space on the centre disk and the device is operated. The device gives the kinetic friction coefficient $(\mu)$ value of the sample surface. In Vidya 3D, this data means a friction between avatar and the fabric. Because of that, results of the backside of the fabric were chosen.

The thickness of the knit pattern is much larger than the one weighed because of the way the two types of materials are obtained. This is also reflected in the weights of the two material samples - the knit is heavier than the fabric. The elongation of the two types of material (in all directions) is significantly higher for knit - this is one of the main characteristics that differentiate the two types of fabrics. The higher the thickness of the knit affects its ability to be bent the bending knit value is almost half that of the fabric. The coefficient of friction is much higher in the case of knit - which will favour the occurrence of the piling phenomenon on the products made of these materials. Even though there are significant differences between the properties of the two types of materials, both are suitable for use in the fabrication of a wide range of clothing products.

After these properties were determined, they were converted to Vidya 3D Software parameters. Vidya uses real material parameters to display the natural stretch behavior and structure of the fabrics. Human, pattern and material interact perfectly so that drape, elasticity and structure correspond to natural movement behavior.

The data collected were used as input for material wizard parameters. Simulations were done by using Human Solutions Assyst Vidya 3D software version 20.17.2.31690. The data collected were used as input for material wizard parameters. In addition, photos of the fabric were taken by a DSLR camera and their textures were transferred to the software for realistic visualization. Further on was created the $2 \mathrm{D}$ dress patterns (figure 4).

The flat pattern pieces were placed on a virtual body. Our aim was to place the patterns as close as possible to the body surface and, for this, a manual

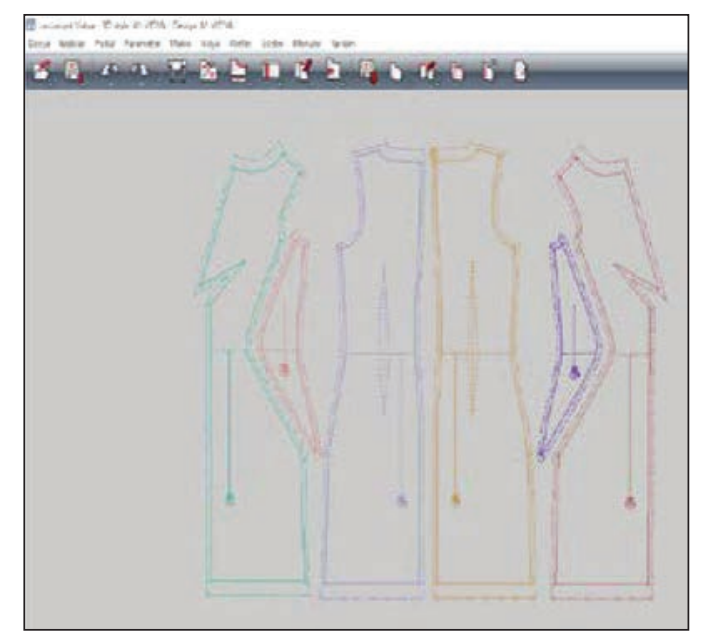

Fig. 4. 2D patterns 


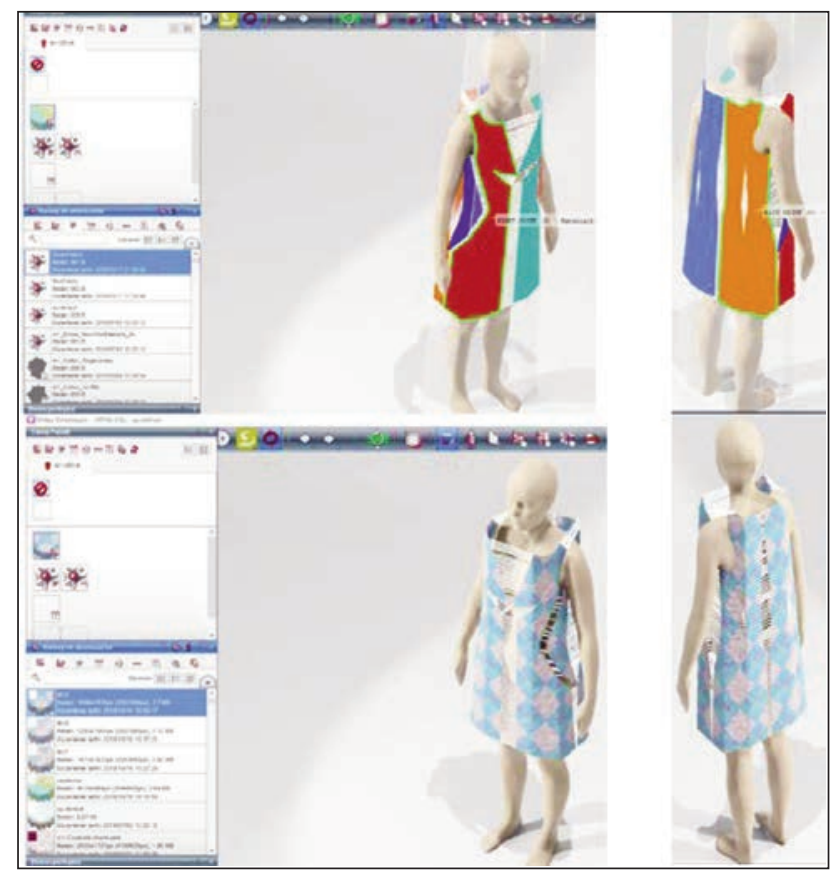

Fig. 5. 2D to $3 \mathrm{D}$ transformation placement with an automatic function was used. Knowing that the seams would bring together the edges of the patterns, it was required to approximate the initial positioning. The space between two seam lines had to be as small as possible in order to get a proper final garment.

The fabrics parameters, and particularly the physical parameters of the knitting and woven texture were adjusted through the garment material wizard panel. There are two categories of parameters in 3D simulation program: global parameters (gravity, collision distance and detection modes) and local parameters (thickness, bending rigidity, friction values and elongation). While global parameters are mainly related with software and how it adjusts the realism in virtualization: local parameters on the other hand are related with the material properties and how the fabric acts in the simulation. The measured fabric parameters of knitted and woven samples were used as input for the garment material wizard panel of the software. Detailed photographs of the samples were taken in well and homogenous-lighted environment,

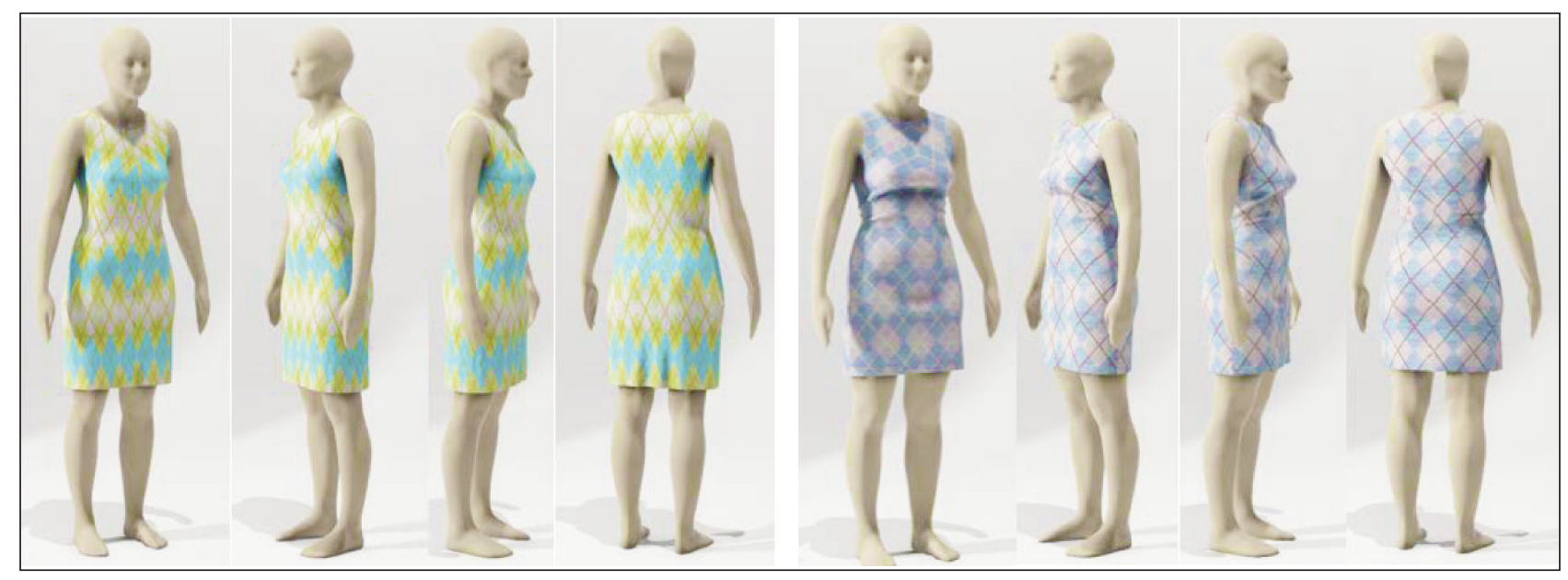

Fig. 6. 3D garments design by using AssystVidya 3D software

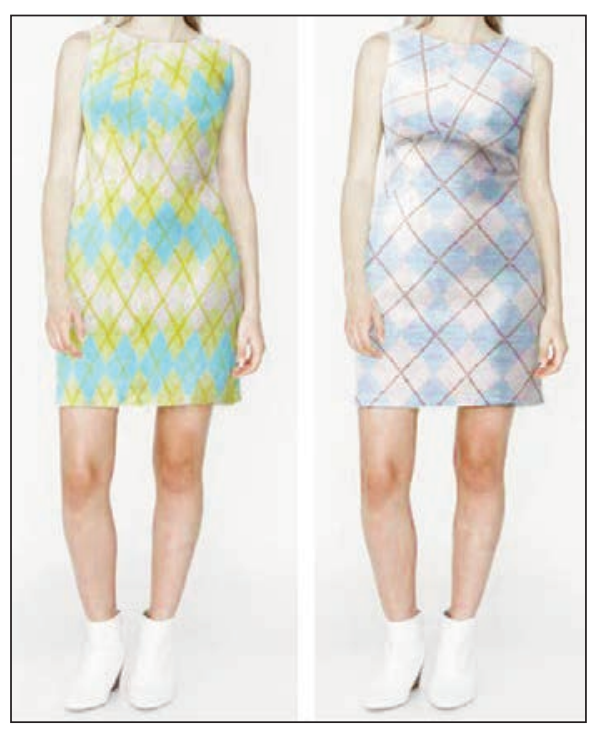

Fig. 7. The final garment they were used as input for the texture panel of the software.

Once the texturing and fabrics parameters were set, the mechanical simulation could be performed in order to observe the "fitting" of the garment. In this way, the surfaces were brought together along the seam lines as shown in figure 5.

After the placement of the patterns around the virtual mannequin, the seaming was executed in order to visualize the virtual product and to simulate fabric drape and fit. Simulation of knitted fabrics can be seen on the left and the woven fabric on the right in figure 6 . The real dresses are shown in figure 7.

\section{CONCLUSIONS}

As a consequence of high-quality clothing demand and strong competition, many manufacturers started to use the automation technology, which enables the 
clothing companies to generate strategy, communicate, and make the whole process quick and precise. Nowadays, the virtual garment simulation is related to an increased speed of the production chain, with great impact on price, on the ability to offer to customers more than two collections in the same year. From the study presented, it can be concluded that the knitted material has a higher thickness and is more voluminous while the woven fabric has more drape and flow resulting from its lower thickness. The knitted loop structure confers high stretch ability and elasticity to the fabric, while the intersection of yarns at right angle gives proper stability and durability to woven fabric. We can say that even though there are significant differences between the properties of the two types of materials analyzed in this paper, both are suitable for use in the design of the dress model proposed in the paper.
3D visualization software allowed us to see and explore the dresses made from woven and the knitted fabrics on a virtual mannequin before the manufacturing. The virtual garment visualization represents an important step in the field of digital design and the apparel manufacturers have shown a special interest in its development. These programs have their own material databases, but apparel companies can also introduce their own materials. The success of this software directly depends on how the material properties and textures are imported into the program which requires experience of the operator. In this study the methods how the material properties were implemented into the program are explained in detail and, by using correct parameters, realistic visualization of dresses were obtained. This automation methodology from fabric design to garment prototype will be beneficial for companies who are willing to save time, labor and cost.

\section{REFERENCES}

[1] Hwang, J.Y., Hahn, K.H., A case study of 2D/3D CAD virtual prototype simulation programs to enhance student performance in student-centered fashion design education, In: Journal of Textile Engineering \& Fashion Technology, 2017, 3, 1, 578-584

[2] Clarke, P., Wilhelm, W., 3D in apparel design: a revolution in the industry, 2011, [Online]. Available: http://www.walterwilhelmassoc.com/news/3D-in-Apparel-Design-A-Revolution-in-the-Industry.cfm

[3] Power, J., Apeagyei, P.R., Jefferson, A.M., Integrating 3D Scanning Data \& Textile Parameters into Virtual Clothing, In: Proceedings of the 2nd International Conference on 3D Body Scanning Technologies, Hometrica Consulting, Lugano, Switzerland, 2011, 213-224. ISBN 978-3-033-03134-0

[4] Durupınar, F., Gudukbay, U., A Virtual Garment Design and Simulation System, [Online]: https://www.researchgate. net/publication/4260995_A_Virtual_Garment_Design_and_Simulation_System

[5] Liu, Y, Zhang, D, Yuen, M.M.,A survey on CAD methods in 3D garment design, In: Computers in Industry, 2010, 61, 6, 576-593

[6] Spahiu, T., Shehi, E., Piperi, E., Personalized avatars for virtual garment design and simulation, In: UNIVERSI International Journal of Education, Science, Technology, Innovation, Health and Environment, Macedonia, 2015, 1, 3

[7] Sayem, A.S.M, Kennon, R., Clarke, N., 3D CAD system for the clothing industry, In: International Journal of Fashion Design, Technology and Education,2010, 3, 2, 45-53

[8] Volino, P., Cordier, F., Magnenat-Thalmann, N., From Early Garment Simulation to Interactive Fashion Design, In: Computer-Aided Design, 2005, 37, 6, 593-608

[9] Ork, N., Mutlu, M., Popescu G., Mocenco A., A study on using 3D visualization and simulation program (Optitex 3D) on leather apparel, In: Annals of the University of Oradea, Fascicle of Textiles, Leatherwork, Oradea, 2016, 16, 2, 191-196

[10] Jevšnik, S., Stjepanović, Z., Celcar, D., Virtual clothes simulations, In: $1^{\text {st }}$ International Conference I Love Inter/ National Fashion, 2009

[11] Harpa, R., Visileanu, E., From fabric design to the dress manufacturing considering the fabric's suitability with the end use, In: Industria Textila, 2018, 69, 6, 434-439, https://doi.org/10.35530/10.35530/IT.069.06.1570

[12] Jevsnik, S., Pilar, T., Stjepanovic, Z., Rudolf, A., Virtual prototyping of garments and their fit to the body, In; DAAAM International scientific book, 2012, 601-618

[13] Fashion in 3D, [Online], Available: https://www.human-solutions.com/vidya/upload/content/weitermachen/ Vidya_Guide_en.pdf

[14] Sungmin, K., Development of a Parametric Design Method for Various Woven Fabric Structures, In: Journal of Engineered Fabrics \& Fibers (JEFF), 2011, 6, 4

[15] Blaga, M., et al., Interactive application for computer aided design of 3d knitted fabrics, In: The 7th International Scientific Conference eLearning and Software for Education, Bucharest, 2011

[16] Indrie, L., Diaz-García, P., Gherghel, S., Development of Jacquard woven fabrics for home decor, In: International Scientific Conference Contemporary Trends and Innovation in the textile industry, 18 May 2018, Belgrade, Serbia, 348-351

[17] Fatahi, I., Yazdi, A.A., Assessment of the relationship between air permeability of woven fabrics and its mechanical properties, In: Surfaces, Fibres and Textiles in Eastern Europe, 2010, 6, 83, 68-71

[18] Peirce, F., The handle of cloth as a measurable quantity, In: Journal of the Textile Institute, 1930, 21, 9, 399 
[19] Allaoui, S., Hivet, G., Wendling, A., Soulat, D., Chatel, S., Experimental Approach for Optimizing Dry Fabric Formability, In: 14th European Conference on Composite Materials, Budapest, Hungary, 2010

[20] Dehkordi, M.T., Nosraty, H., Shokrieh, M.M., Minak, G., Ghelli, D., Low Velocity Impact Properties of Intra-Ply Hybrid Composites Based on Basalt and Nylon Woven Fabrics, In: Materials \& Design, 2010, 31, 8, 3835-3844

[21] Merati, A., Patir, H., Anisotropy in Wrinkle Properties of Woven Fabric, In: The Journal of the Textile Institute, 2011, 102, 7, 639-646

[22] Tohidi, S.D., Jeddi, A., Nosrati, H., Analyzing of the Woven Fabric Geometry on the Bending Rigidity Properties, In: International Journal of Textile Science, 2013, 2, 4, 73-80

\section{Authors:}

\section{LILIANA INDRIE¹, MEHMET METE MUTLU², NILAY ORK EFENDIOGLU²,} SIMONA TRIPA ${ }^{1}$, PABLO DIAZ GARCIA ${ }^{3}$, MIQUEL SOLER ${ }^{4}$

${ }^{1}$ University of Oradea, Faculty of Energy Engineering and Industrial Management, Department of Textiles, Leather and Industrial Management, B.St. Delavrancea 4, Oradea, Romania e-mail: liliindrie@yahoo.com, tripasimona@yahoo.com

${ }^{2}$ Ege University, Engineering Faculty, Department of Leather Engineering, Bornova, Izmir, Turkey e-mail: mete.mutlu@ege.edu.tr, nilay.ork@ege.edu.tr

3Universidad Politécnica de Valencia, Escuela Politécnica Superior de Alcoy, Dpto. Ingeniería Textil y Papelera, Plaza Ferrandiz y Carbonell s/n, 03801 Alcoi, Spain e-mail: pdiazga@txp.upv.es

${ }^{4}$ Centre de Recerca i Transferència de TecnologiaTèxtil de Canet de Mar, Plaça de la Industria, 08360 Canet de Mar, Barcelona, Catalonia, Spain e-mail: solerlm@diba.cat

Corresponding author:

\section{LILIANA INDRIE}

e-mail: liliindrie@yahoo.com 


\title{
Numerical simulation of the effect of flow field in swirl nozzle spinning on yarn performance
}

\author{
DOI: $10.35530 / I T .070 .06 .1422$
}

\section{ABSTRACT - REZUMAT}

Numerical simulation of the effect of flow field in swirl nozzle spinning on yarn performance

Swirl nozzle spinning is an effective method to reduce ring-spun yarn hairiness due to device structure and vortex characteristics. This study establishes a computational domain of a swirl nozzle comprising an air inlet channel and a yarn channel to investigate the characteristics of the vortex in the swirl nozzle and the effects of inlet pressure on the wrapped force of the yarn. Simulation results show that the airflow rotates clockwise toward the two yarn entrance directions; moreover, the pressure at the central area of the yarn channel is lower than that of the surrounding area, which is good for the yarn's steady movement and free fibers wrapping on the yarn surface into the yarn body. When the inlet pressure is high, the pressure spreading to each section of the yarn channel is also high. When the difference between the pressure near the inner wall and the yarn axis is high, the yarn surface has added high pressure, and the velocity and its fluctuation are also high. Experiment result reveals that $0.2 \mathrm{MPa}$ is sufficient in significantly reducing yarn hairiness and that operating the nozzle under a low air pressure is economical. Thus, the numerical simulation can provide the theoretical as well as quantitative reference for the vortex tube design in the coming future.

Keywords: swirl nozzle, vortex, hairiness, free fiber, inlet pressure

Simularea numerică a influenţei câmpului de curgere în filarea cu duze în spirală asupra performanței firului

Filarea cu duze în spirală este o metodă eficientă pentru a reduce pilozitatea firelor filate cu inele datorită structurii dispozitivului și a caracteristicilor sistemului Vortex. Acest studiu stabilește un domeniu de calcul al parametrilor de proiectare a duzelor în spirală, care sunt formate dintr-un canal de intrare a aerului și un canal de fire, pentru a investiga caracteristicile sistemului Vortex în duza în spirală și influenţa presiunii de intrare asupra forței de înfășurare a firului. Rezultatele de simulare arată că fluxul de aer se rotește în sens orar spre cele două direcții de intrare ale firelor; în plus, presiunea în zona centrală a canalului de conducere a firelor este mai mică decât cea a zonei înconjurătoare, ceea ce este corespunzător pentru mișcarea uniformă a firelor și înfășurarea fibrelor libere pe suprafața firelor în corpul firelor. Când presiunea de intrare este ridicată, presiunea distribuită pe fiecare sectiune a canalului de conducere a firelor este, de asemenea, ridicată. Când diferența dintre presiunea din apropierea peretelui interior și presiunea din axa firelor este mare, suprafața firelor prezintă o presiune ridicată, iar viteza și fluctuația sa sunt, de asemenea, ridicate. Rezultatul experimentului arată că o valoare de 0,2 MPa este suficientă pentru a reduce semnificativ pilozitatea firelor, iar funcționarea duzei la o presiune scăzută a aerului este economică. Astfel, simularea numerică poate oferi o referință teoretică, precum și cantitativă pentru proiectarea tubului vortex în viitorul apropiat.

Cuvinte-cheie: duză în spirală, vortex, pilozitate, fibră liberă, presiune de intrare

\section{INTRODUCTION}

Yarn hairiness is a key factor affecting yarn and fabric processes and properties. Some new technologies have been developed to reduce the hairiness of ring spun yarns, such as compact spinning [1-2], jet ring spinning [3] and the use of a contact surface or air nozzle [4]. Initially introduced in 2012, swirl nozzle spinning is a novel method to reduce ring yarn hairiness [5]. Vortex nozzle ring spinning is composed of a yarn channel and an air jet nozzle, and it is attached to a traditional ring spin frame (figure 1). When compressed air from the air jet nozzle to the yarn duct is applied, the swirling airflow tucks the surface fibers of the ring-spun yarn into its body to decrease yarn hairiness. Compared with the other methods above, swirl nozzle spinning is simple to install, easier to operate, and cost lower. This method

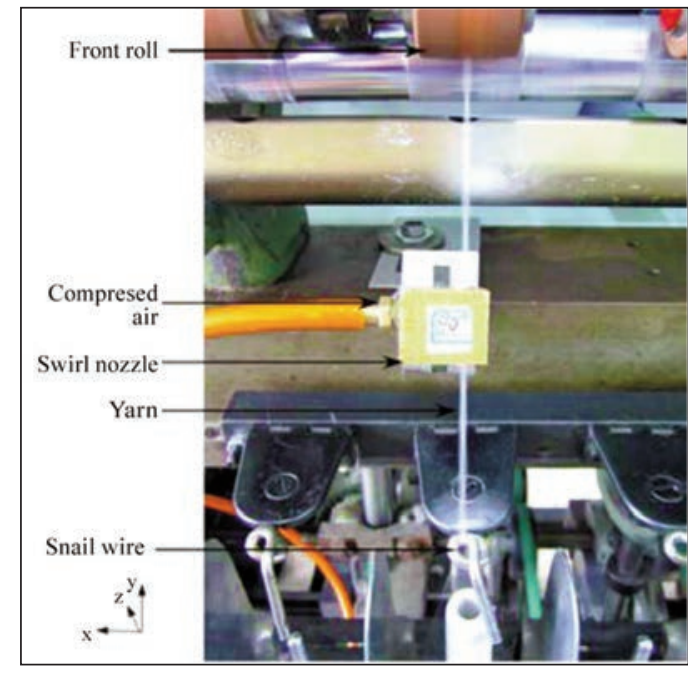

Fig. 1. Swirl nozzle and Installation 
has a remarkable capacity in reducing hairiness [6]. Some studies on reducing ring-spun yarn hairiness have been conducted through experimental methods, but the mechanism remains unclear. Therefore, the present work focused on investigating the effect of airflow in the nozzle and different air inlet pressure on the fiber of the yarn surface using numerical and experimental methods. Numerical simulation can provide the theoretical basis for the experiment result, which plays an important role in optimizing the structure of the nozzle and test parameters.

\section{NUMERICAL SIMULATION}

\section{Simulation model}

Figure 2, a presents the 3D geometric model of a swirl nozzle, including the airflow inlet and yarn guide channels. In the figure, compressed air flows into the yarn path from the air inlet. When the airflow arrives at the junction of the airway and yarn path, it reaches a relatively high pressure. Subsequently, the air vortex possessing axial and circumferential velocities is simultaneously generated in the yarn path to make the yarn hairiness stick take before flowing out from the two outlets. The corresponding Outlets 1 and 2 are simultaneously the exits of the airflow and the import and export of the yarn. Figure 2,b shows the structural parameters of the swirl nozzle. Airway tangents clockwise to the yarn path, which divides the yarn into two unequal parts. Airway diameter is smaller than that of the yarn path.

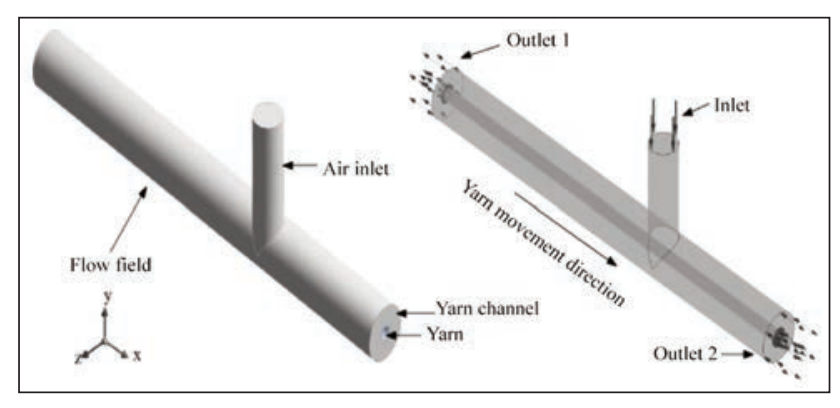

a

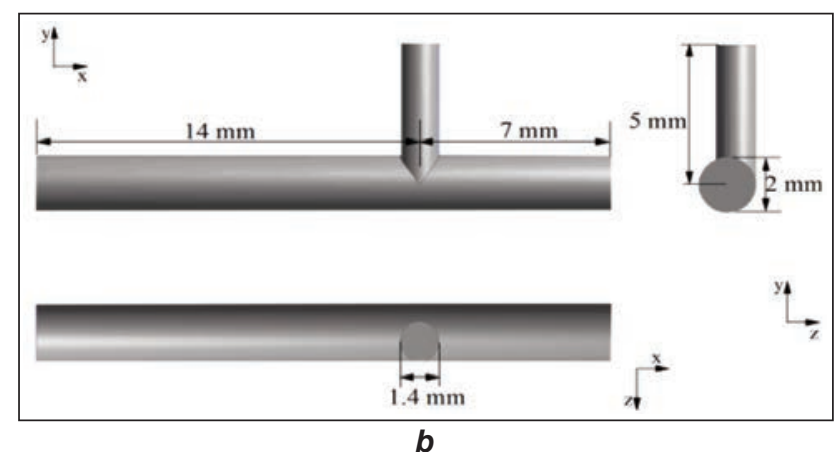

Fig. 2. Fluid domain parameter of the swirl nozzle: $a$ - fluid domain of the swirl nozzle; $b$ - three view drawing of fluid domain of the swirl nozzle

\section{Method of numerical simulation}

Simulation method combined with theoretical analysis and experimental method is widely used to solve application problems in textile, thereby improving the efficiency of problem solving [7-9]. In this study, CFX (CFD software) is used to simulate the airflow in the swirl nozzle. The computational domain is meshed using an unstructured tetrahedral grid. Inflation layer is used inside the yarn channel wall to provide a more accurate prediction of flow characteristics [10]. In addition, the airflow is considered as viscous and incompressible. Turbulence model is adopted for the turbulence.

\section{Boundary conditions}

The simulation model is a computational domain with a fluid inlet and two outlets. Various inlet pressures are set. The pressure, temperature, and velocity of the inlet are set as follows:

$$
\begin{gathered}
P_{\text {in }}=(p+0.1013) \times 0.528 \\
T_{\text {in }}=0.833 T \\
v_{\text {in }}=\sqrt{\gamma R T_{\text {in }}}
\end{gathered}
$$

Where $p$ is the pressure in the store jar $(p=0.05$, $0.10,0.15,0.20,0.25 \mathrm{MPa}), T$ - atmospheric temperature $(T=293 \mathrm{~K}), \gamma$ is specific heat capacity (for ideal gas, $\gamma=1.4), R$ - universal gas constant $(R=$ $287.1 \mathrm{~J} / \mathrm{Kg} \cdot \mathrm{K})$.

The outlet pressure is equal to the atmospheric pressure $(0.1013 \mathrm{MPa})$. All walls are regarded as nonslip, and an adiabatic boundary condition is imposed in the calculation area; thus, the flow velocity is zero and no heat transfer occurs at the wall. The yarn material is considered as structural steel, and airflow cannot pass into the yarn interior; thus, yarn deformation is ignored.

\section{RESULT AND DISCUSSION}

\section{Characteristics of the swirl nozzle vortex}

Figure 3 shows the flow trajectories of the compressed air in the swirl nozzle. As illustrated, a blast of compressed air flows from the air inlet into the yarn channel. The airflow along the circular yarn channel rotates and generates a strong vortex composed of circumferential and axial velocities and exits from the two outlets. Moreover, the airflow immediately enters the yarn channel from the air inlet, the pressure of the

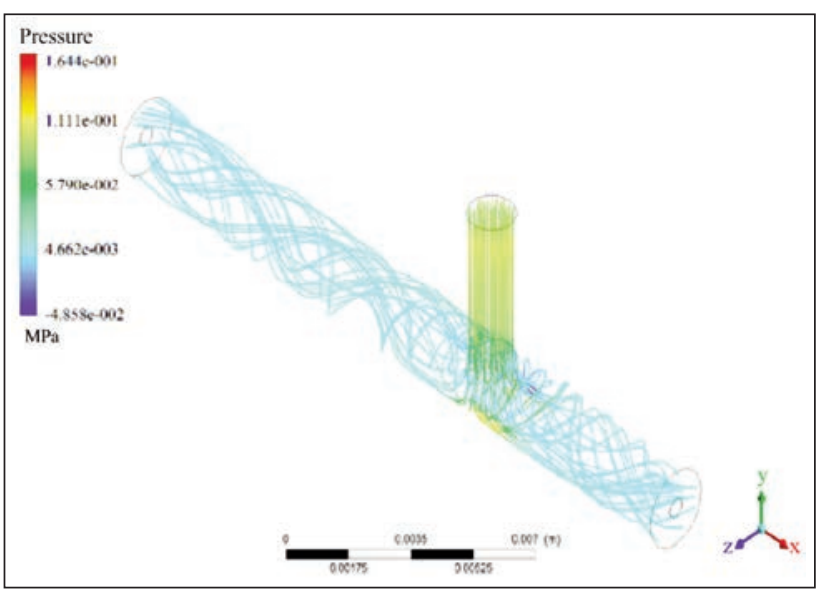

Fig. 3. Flow trajectories in the swirl nozzle 
yarn channel wall peaks and then gradually reduces gradually to flow into the outlets. The pressure at the central area of the yarn channel is lower than that of the surrounding area, which is good for the yarn's steady movement.

The rotating channels on both sides are an asymmetrical structure; thus, the distances of the air inlet to two outlets differ. The longer distance is of the untwisted area; the airflow rotates clockwise toward the yarn entrance direction, which is in the opposite direction of the yarn twist direction. The shorter distance is of the re-twisted area; the airflow rotates clockwise to the yarn exit direction, which is in the same direction of yarn twist direction.

As plotted in figure 4,a, yarn twist zone and twist zone length differ; to analyze the vortex characteristics, 15 cross-sections of the rotating channel are extracted. As shown, section $\mathrm{O}-\mathrm{O}$ is selected to describe the airflow characteristics, which immediately enters the rotating channel from the air inlet. Section $\mathrm{H}-\mathrm{H}$ and $\mathrm{F}^{\prime}-\mathrm{F}^{\prime}$ are chosen because it is located near the outlet of the rotating channel, where yarn enters and exits. The rest of sections are placed to observe the development of the vortex.

Figure 4, $b$ presents the distribution of velocity vector in diferent cross-sections while the inlet pressure is set to $0.5 \mathrm{MPa}$. The two symmetrical sections have the same velocity vector distributions, where an obvious vortex is evident. As shown, longer arrow means faster airflow velocity; high velocity airflow distributes around the surface of the yarn, which is advantageous for wrapping long fibers of yarn surface. In addition, the circumferential velocity decreases along the two sides of the rotating channel.
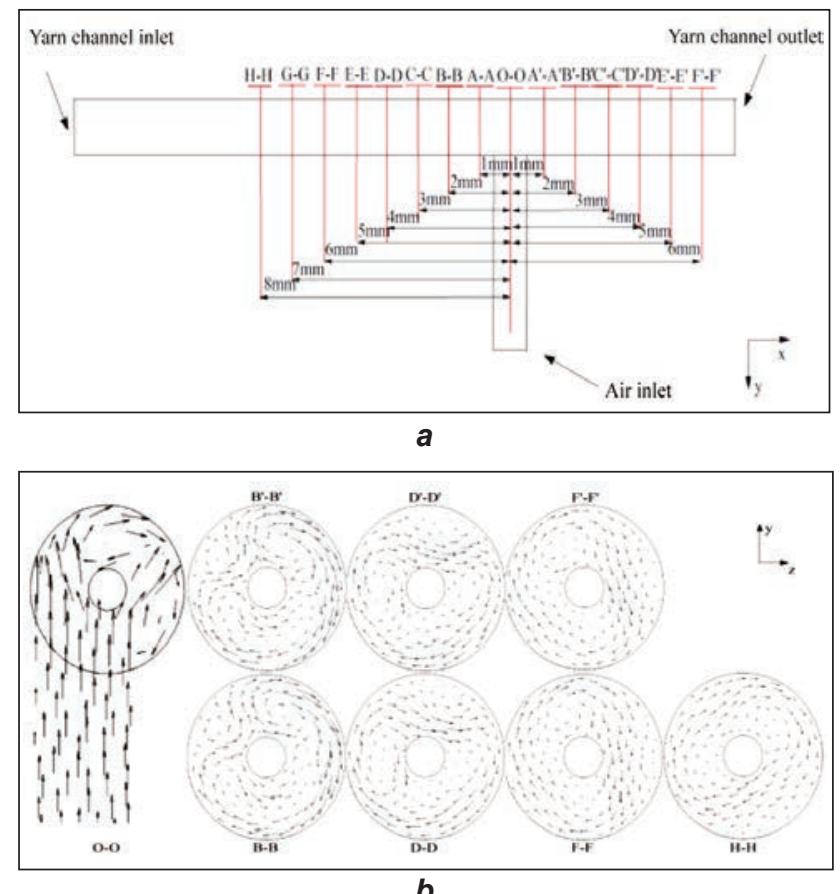

b

Fig. 4. Circumferential velocity vector in the yarn channel: $a$ - cross sections of the yarn channel in different positions; $b$ - circumferential velocity vector in the yarn channel in various cross-section
Effects of the vortex on the fiber on the yarn surface

As shown in figure 5 , the forces generated by the airflow are the wrapped forces $F$ and $F^{\prime}$, which are the resultant forces of $F 1$ (along the $x$-axis), $F 2$ (along the $y$-axis), and $F 3$ (along the z-axis), and $F 1^{\prime}$ (along the $x$-axis), F2' (along the $y$-axis), and F3' (along the $z$-axis), respectively. In addition, the relative revolving action $F_{r}$ and $F_{r} 1^{\prime}$ is also applied on the free end of fiber due to the self-twisting of the yarn. Thus, the total wrapped forces $F_{T}$ and $F_{T}^{\prime}$ acting on the fibers on the yarn surface can be obtained as follows:

In the untwisted area, airflow acts on the consequent hairiness mainly as follows:

$$
\begin{gathered}
F_{T}=F+F_{r}^{\prime} \\
F_{T}=F+F_{r}^{\prime} \vec{F}=\overrightarrow{F 1}+\overrightarrow{F 2}+\overrightarrow{F 3}
\end{gathered}
$$

In the re-twisted area, airflow acts on the consequent hairiness mainly as follows:

$$
\begin{gathered}
F_{T}^{\prime}=F^{\prime}+F_{r} 1^{\prime} \\
\overrightarrow{F^{\prime}}=\overrightarrow{F 1^{\prime}}+\overrightarrow{F 2^{\prime}}+\overrightarrow{F 3^{\prime}}
\end{gathered}
$$

According to the formula of flow around the cylinder, the forces generated by the airflow are related to pressure and airflow velocity [11].

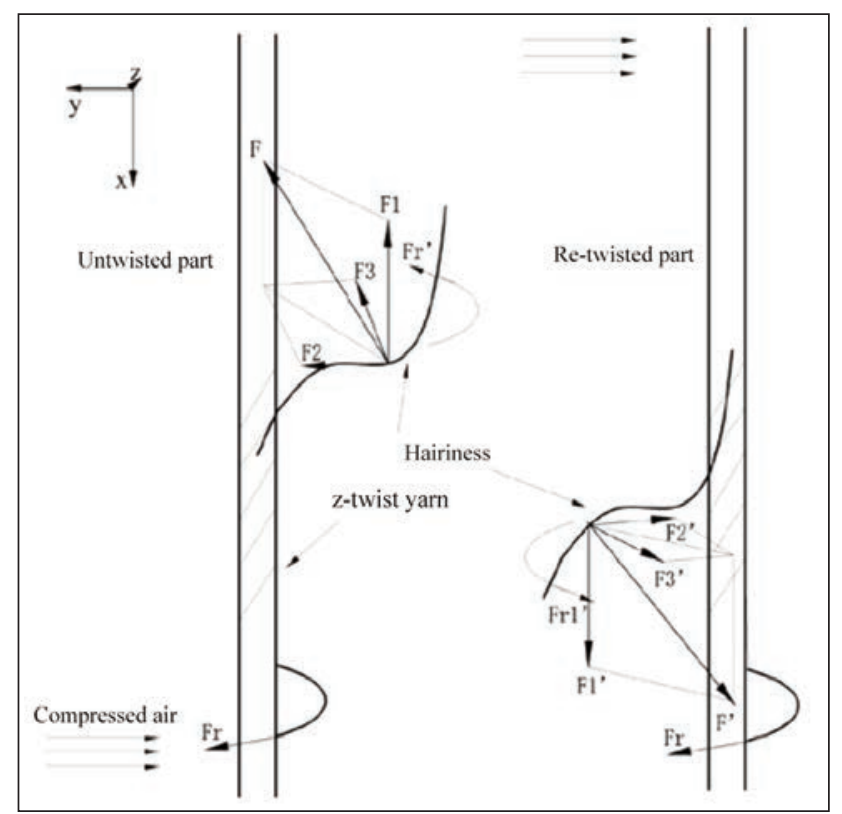

Fig. 5. Force schematic diagram of the yarn under the airflow condition

\section{Effects of inlet pressure on the wrapped force} of the yarn

Considering that yarn requires the proper wrapping force to attach yarn hairiness, the comparisons of the vortex pressure in the different cross-sections under diferent inlet pressures with $0.05,0.10,0.15,0.20$, and $0.25 \mathrm{MPa}$ are presented in figure $6, a$. As shown, the negative pressure zone produced by the airflow acting on the yarn at the yarn channel entrance spreads progressively small with the increase in inlet 
pressure; this phenomenon occurs because when the inlet pressure is higher, the pressure spreading to each section of the yarn channel is higher; the subsequent greater pressure difference existing near the inner wall and yarn axis makes for an easier hold of the yarn, thereby resulting in its steady movement and effective functioning as wrapping fibers. Hair is subjected to a higher total air pressure due to a reducing pressure gradient from the inner wall of the yarn channel to the axis.

Figure $6, b$ shows the yarn surface in the simulated nozzle under different air pressures. Clearly, yarn surface has added high pressure area with the increase in inlet pressure and high and low pressure alternating distribution, thereby easily wrapping the free fibers into the yarn body. However, a significant high pressure would break the yarn structure and blow away some free fibers, which may cause fiber loss. Thus, the air pressure should be properly selected in the actual processing.

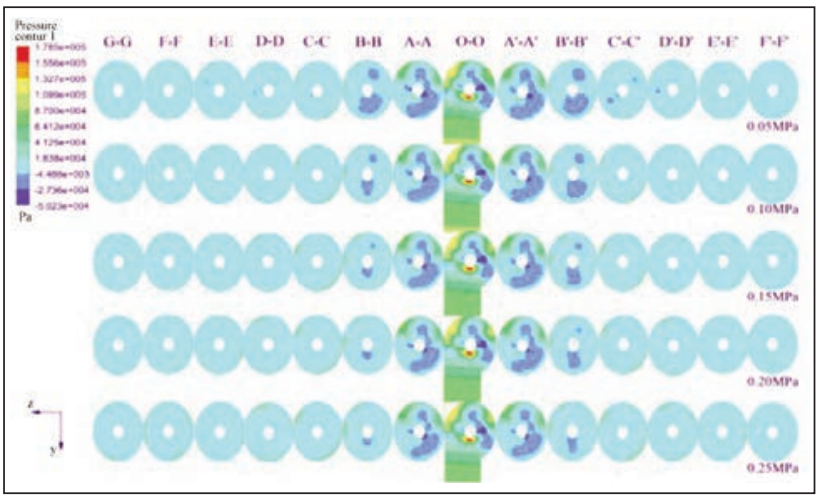

a

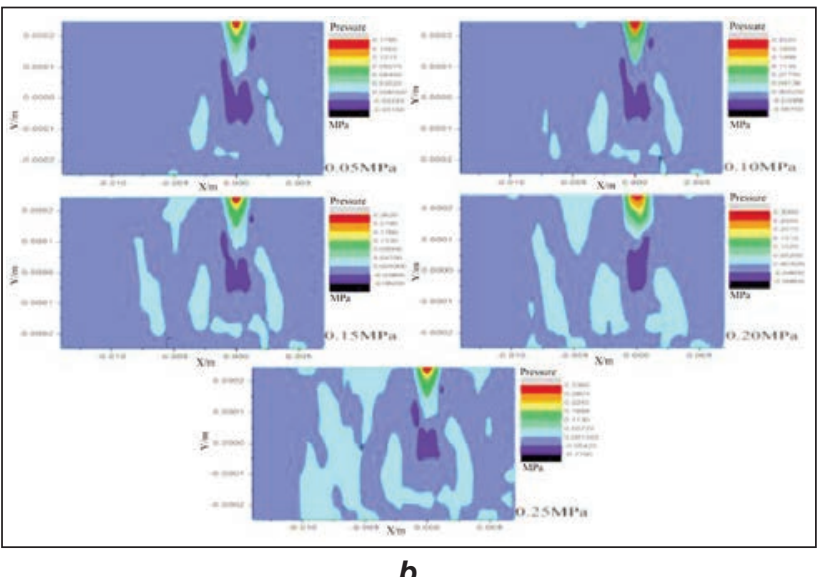

Fig. 6. Pressure distribution of swirl nozzle and yarn surface: $a$ - pressure distribution in various yarn channel sections under different pressure conditions;

$b$ - pressure distribution of yarn surface under different pressure conditions

Wrapped force acting on the yarn surface is known to depend on the surface pressure and velocities $u, v$, and $w$. Four lines on the yarn surface are selected as the research objects to study the effect of inlet pressure on yarn; the lines are marked Line A, Line B, Line $C$ and Line $D$, as shown in figure 7.

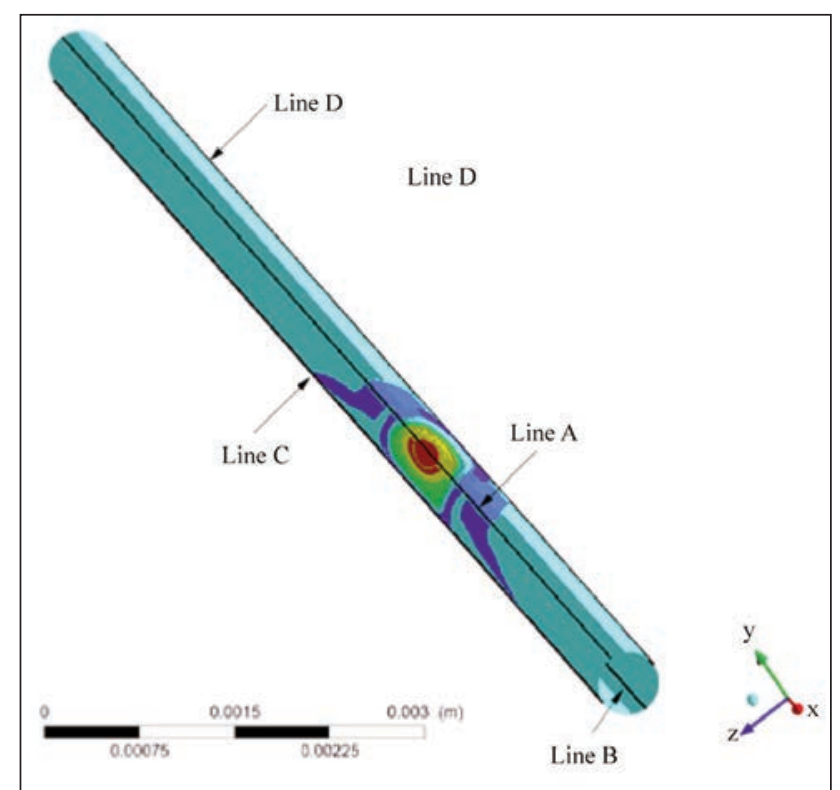

Fig. 7. Position of the four lines selected from the yarn surface

Figure 8 shows the pressure of air acting on the yarn surface under different inlet pressures. The total pressure trend acting on the yarn under different inlet pressure levels are similar. For Line A, the air comes from the air entrance; whereas the pressure suddenly increases near the wall of the yarn channel. This sudden increase in pressure is due to the generation of shock waves, which changes the direction of the airflow movement and creates a swirling effect toward two directions. Then, the pressure decreases due to the presence of two air exits, where air diffuses very quickly and then stabilizes gradually. Under different inlet pressures, the impact of airflow acting on the yarn is greater in the junction of the yarn channel and airway with the increase of inlet pressure. Pressure difference becomes gradually smaller with air flowing out the yarn channel. The pressure generated by Line B increases and decreases; a higher inlet pressure means a greater pressure fluctuation. To some extent, this trend of pressure is advantageous to wrap yarn surface fibers and push down the fiber of the yarn surface from a high-pressure area to a low-pressure area. Lines $C$ and $D$ located on the two sides of the yarn surface have a similar change trend, which generates a high negative pressure, subsequently undergoes pressure recovery, and eventually levels off. Inlet air pressure affects the negative pressure and air pressure fluctuation. To sum up, the yarn surface requires moderate pressure; if too low, the force is insufficient to wrap the yarn; if too high, the free fibers are easily blown away, thereby causing fiber loss and yarn tenacity.

The total air velocity acting on the yarn is resolved into velocity $u$ (along the $x$-axis), velocity $v$ (along the $y$-axis), and velocity $w$ (along the z-axis). Velocity $u$ holds the yarn and makes it move steadily. Velocities $v$ and $w$ play the function of attaching and wrapping free fibers on the yarn surface [12]. Figure 9 shows the axial component of the air velocity on the yarn 
surface under various inlet pressures inside the nozzle. Four lines have similar trends on velocity $u$; whereas axial air velocity suddenly increases near the yarn channel. Then, axial velocity decreases with air flowing out the two exits. Thus, the delivery effect of airflow on the yarn is becoming smaller. For different inlet pressures, no difference exists in a short distance while entering the yarn channel; then, pressure increases with air flowing to the exits. A higher pressure and greater speed at some point means closer to export and more evident difference.
Velocity $v$ (along the $y$-axis) and velocity $w$ (along the $z$-axis) play the function of opening the yarn structure and wrapping free fiber into the yarn body. Figure 10 shows the $y$-axis component of the air velocity on the yarn surface under various inlet pressures inside the nozzle. For Lines A and B, Y axial velocities are irregular wavy lines. The significant fluctuation in Line $B$ indicates that the air at the bottom of the yarn velocity changes more along the $x$-axis. The force acting on each position is uneven, which is good for attaching the surface free fibers. Compared with Lines $A$
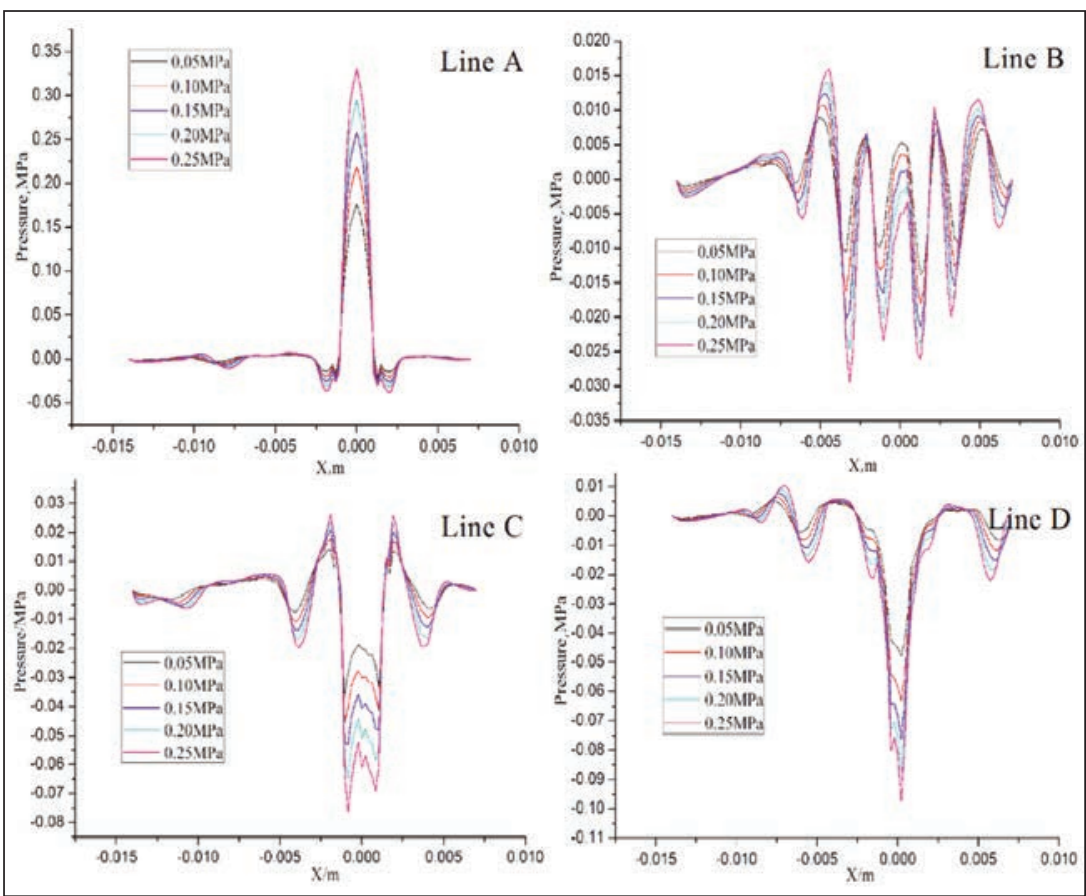

Fig. 8. Pressure distribution of the four lines located on the yarn surface under different pressure conditions

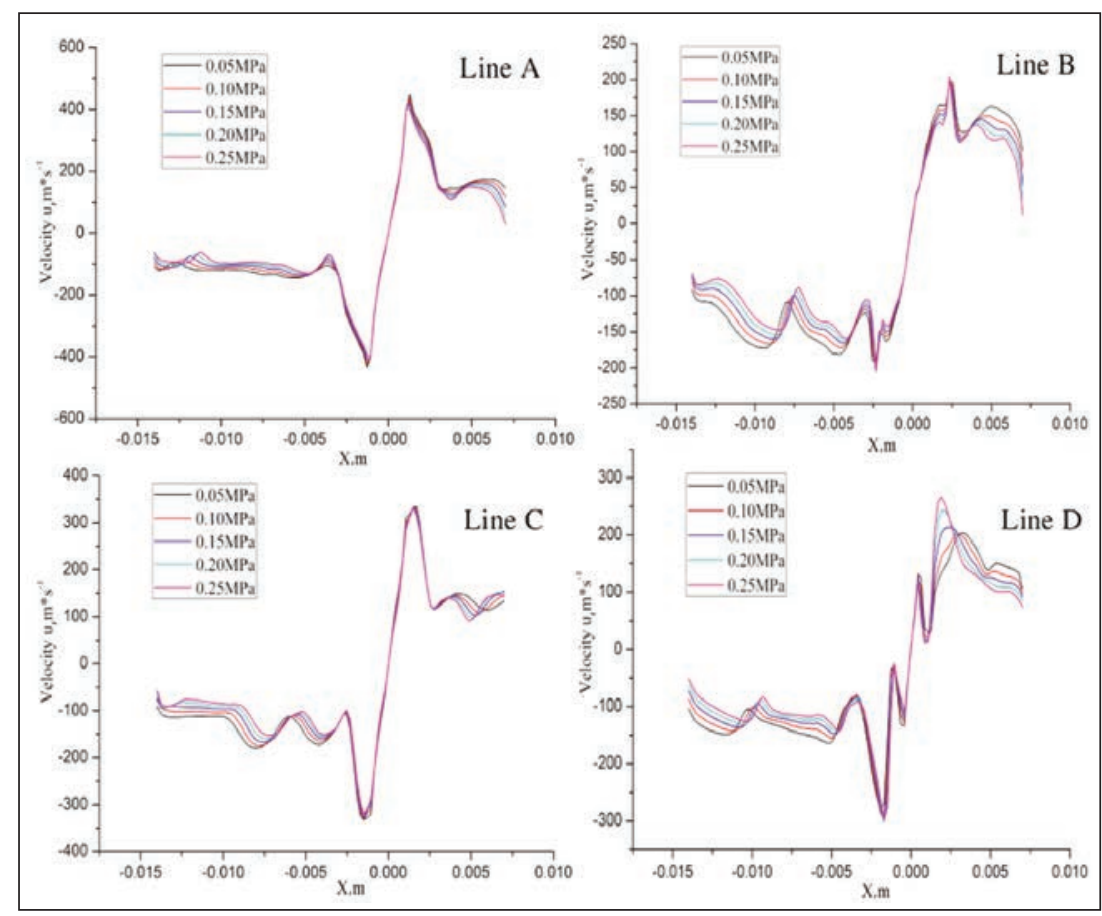

Fig. 9. Velocity $u$ distribution of the four lines located on the yarn surface under different pressure conditions and $B$, Lines $C$ and $D$ have smaller changes, except that the velocity in $x=0$ is high. This phenomenon occurs because the air flow inlet direction moves toward the negative direction of the $y$-axis. Different inlet air pressures create different velocities on the y-direction. A higher inlet pressure means faster speed; however, the overall difference is not evident.

The graph for Line $A$ in figure 11 indicates a great speed fluctuation when the inlet pressure is high. A large difference in velocity is known to have an increased advantage to the wrapped yarn. A higher speed can also create a more sufficient opening for the yarn structure and increase the likelihood of the fiber to be posted on the yarn surface. Under different inlet pressure levels, the fluctuation of velocity $w$ of Lines $B, C$, and $D$ is smaller than that of Line $A$.

\section{EXPERIMENTAL METHOD}

An experimental bench was designed to verify the numerical simulation results. Yarn performance tests based on conventional ring spinning and swirl nozzle spinning were designed to validate the effect of airflow on the yarn hairiness. Alternately, a hairiness tester was used to measure the yarn hairiness index under different inlet pressures, thereby verifying the reasonableness of the theoretical analysis presented in the above section.

The corresponding experimental parameters are listed in table 1. Four types of yarns were produced. Two of these yarns were spun using the conventional ringspinning system (Samples 1 and $3)$, whereas the other two yarn were spun using a ring-spinning machine with a vortex nozzle 

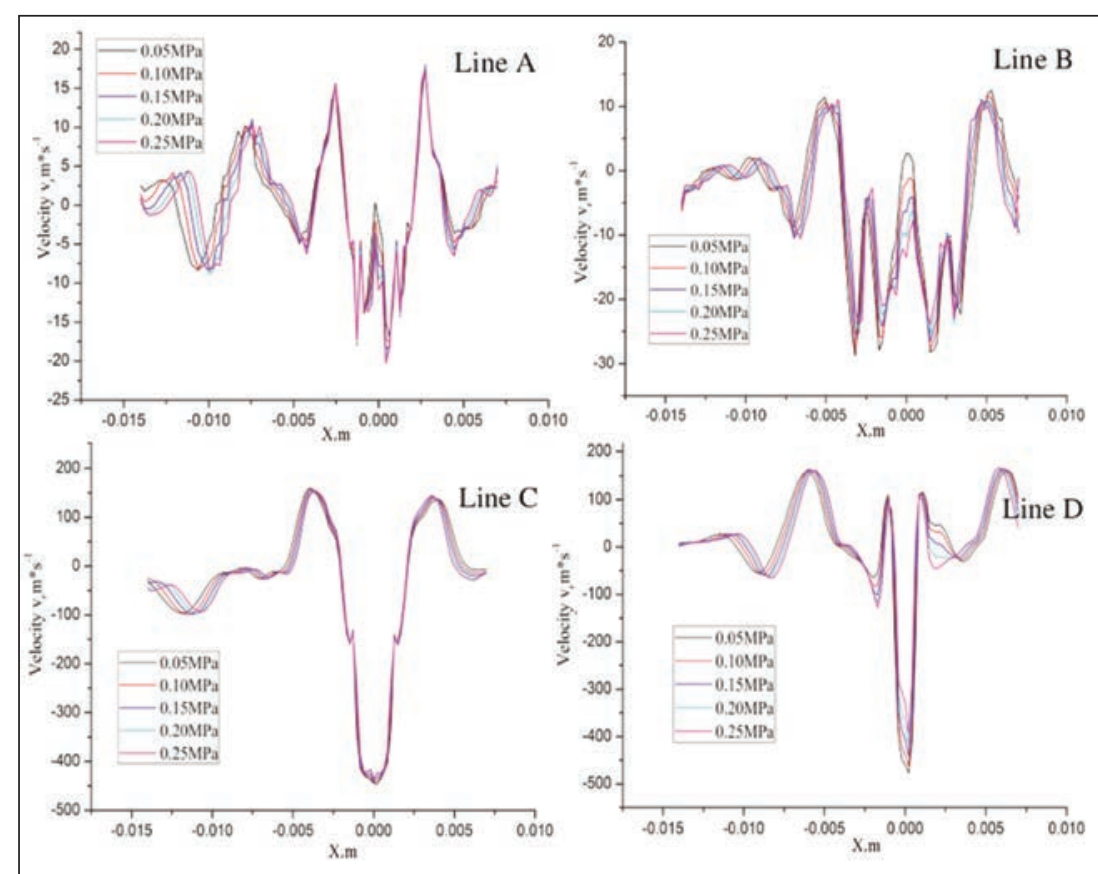

Fig. 10. Velocity $v$ distribution of the four lines located on the yarn surface under different pressure conditions

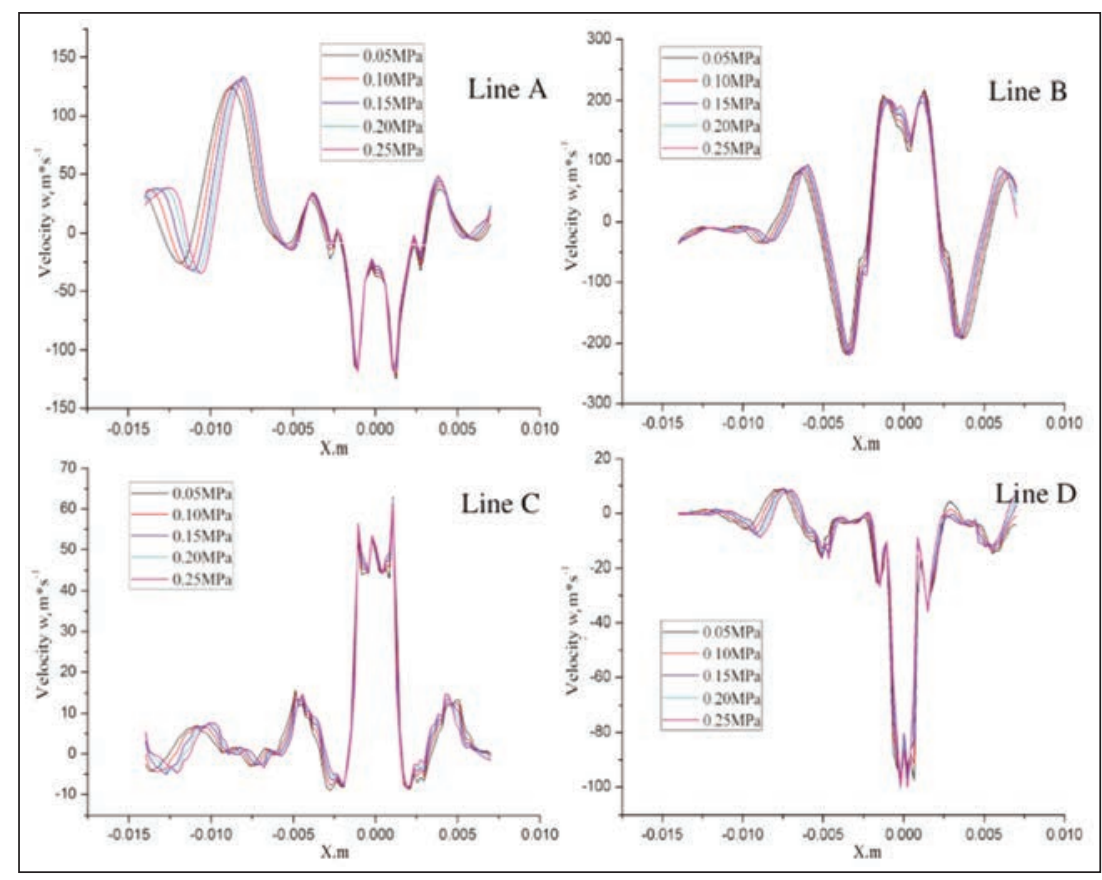

Fig. 11. Velocity $w$ distribution of the four lines located on the yarn surface under different pressure conditions installed between the front roller and the yarn guide of a CZJF-5 multi-function spinning frame (Samples 2 and 4). Samples 1 and 2, as well as Samples 3 and 4 , possessed the same roving and spinning process parameters and were spun into the same specifications.

Yarn hairiness was measured on a YG172A hairiness meter, with reference to the industry standard FZ/T 01086-2000 (the determination method of textile yarn hairiness is the projection-counting method).

The hairiness index (number of hairs on the yarn with a length equal to or exceeding $3 \mathrm{~mm}$ per meter) was used as the means to compare the hairiness level among the different yarns. The hairiness index of yarns spun with and without the vortex nozzle apparatus were compared, as shown in figure 2. Clearly, the hairiness index of vortex-nozzle-spun yarns is less than those of conventionally spun yarns under different air pressure values. The hairiness index under an air pressure of $0.2 \mathrm{MPa}$ is less than those under other air pressure values. With increasing air pressure, the vortex nozzle has a more obvious effect on reducing hairiness at less than 0.2 MPa. Beyond 0.2 MPa, the yarn hairiness number increases. Thus, an air pressure of $0.2 \mathrm{MPa}$ is clearly sufficient in reducing the yarn hairiness, and operating the nozzle at a low air pressure is also economical.

Simulation and experiment results show that yarn hairiness index decreases with the increase of inlet pressure from $0.05 \mathrm{MPa}$ to $0.2 \mathrm{MPa}$. The high pressure creates

\begin{tabular}{|c|c|c|c|c|c|}
\hline \multicolumn{7}{|c|}{ SPINNING EXPERIMENT PARAMETERS } \\
\hline Sample number & Yarn type & Material & $\begin{array}{c}\text { Linear density } \\
\text { (Tex) }\end{array}$ & Twist factor & $\begin{array}{c}\text { Spindle speed } \\
\text { (rpm) }\end{array}$ \\
\hline Sample 1 & Conventional yarn & $\begin{array}{l}20 \% \text { hemp, } \\
80 \% \text { cotton }\end{array}$ & 30 & 450 & 9000 \\
\hline Sample 2 & Vortex nozzle yarn & $\begin{array}{l}20 \% \text { hemp, } \\
80 \% \text { cotton }\end{array}$ & 30 & 450 & 9000 \\
\hline Sample 3 & Conventional yarn & $\begin{array}{l}20 \% \text { hemp, } \\
80 \% \text { cotton }\end{array}$ & 30 & 500 & 9000 \\
\hline Sample 4 & Vortex nozzle yarn & $\begin{array}{l}20 \% \text { hemp, } \\
80 \% \text { cotton }\end{array}$ & 30 & 500 & 9000 \\
\hline
\end{tabular}




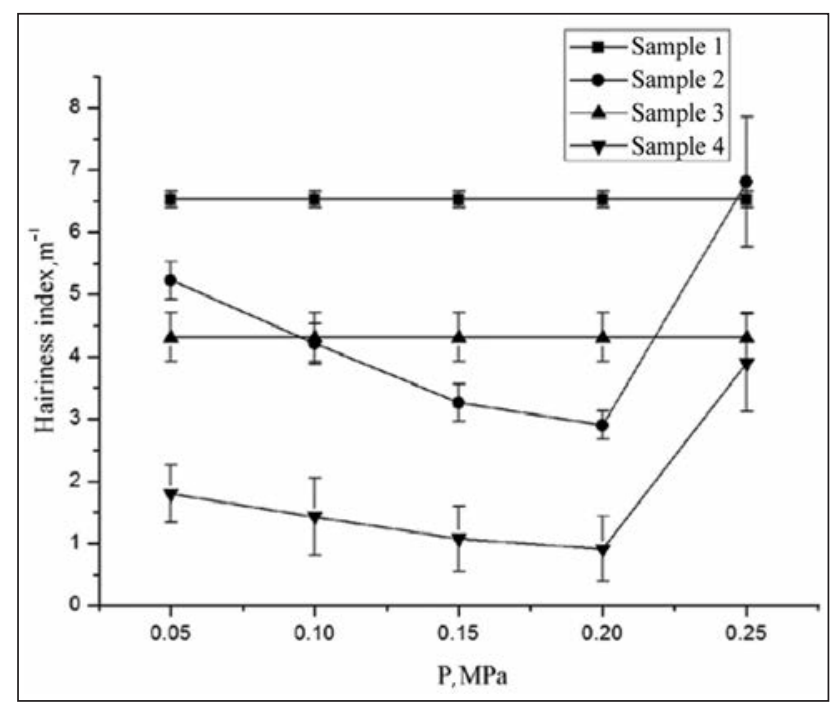

Fig. 12. Comparison of the hairiness index of yarns under different air pressures

a more efficient untwist and re-twist actions; in addition, a stronger wrapped force acts on the yarn surface. However, if the inlet pressure is significantly high, the yarn structure may be blown away and loosened, which will cause a significant loss of fibers and will influence yarn quality.

In order to study the effect of swirl nozzle on other yarn performances at the same time of reducing yarn hairiness under $0.2 \mathrm{MPa}$ air pressure, such as strength, unevenness and the number of short hairiness, breaking strength, unevenness and short hairiness number of four samples were tested, the results showed in table 2. Yarn tenacity was determined on an YG063 automatic single yarn strength tester. Yarn unevenness was measured on YG135G automatic unevenness measurement device.

Table 2

STUDY THE EFFECT OF SWIRL NOZZLE ON OTHER YARN PERFORMANCES

\begin{tabular}{|c|c|c|c|}
\hline $\begin{array}{c}\text { Sample } \\
\text { number }\end{array}$ & $\begin{array}{c}\text { Number of } \\
\text { short hairiness } \\
\text { (1-2 } \mathbf{~ m m})\end{array}$ & $\begin{array}{c}\text { Breaking } \\
\text { strength }\end{array}$ & Unevenness \\
\hline Sample 1 & 61.96 & 226.2 & 11.51 \\
\hline Sample 2 & 72.3 & 201.2 & 12.95 \\
\hline Sample 3 & 69.9 & 242 & 11.45 \\
\hline Sample 4 & 82.4 & 215.6 & 13.5 \\
\hline
\end{tabular}

As shown in table 2, swirl nozzle increase the number of short hairiness as well as yarn unevenness slightly, and decrease the yarn strength. More short hairiness will not affect the quality of yarn and subsequent processing, which makes the yarn and fabric feel fuller. Despite swirl nozzle deteriorate yarn strength and evenness, but the difference is not obvious, and the yarn still meets the requirements of Grade A quality according to standard FZ/T 320042009.

\section{CONCLUSION}

A process of hairiness reduction is explained with the assistance of CFD. The swirling effect of air caused by the nozzle design mainly explains hairiness reduction. Air inlet pressure is an influencing factor in reducing yarn hairiness. The conclusions of this study can be drawn as follows:

(1) The numerical simulation shows the vortex characteristics in the swirl nozzle. The airflow rotates clockwise toward the two yarn entrance directions; moreover, the pressure at the central area of the yarn channel is lower than that of the surrounding area, which is good for the yarn's steady movement and wrapping of free fibers on the yarn surface into the yarn body. The upward movement of the airflow stick takes consequent hairiness and opens the yarn structure; whereas the downward movement of the airflow stick takes reverse hairiness and wraps the fiber into the yarn body.

(2) The forces generated by the airflow acting on the yarn are the wrapped force and the relative revolving action due to the self-twisting of the yarn, which works together to reduce yarn hairiness on the surface.

(3) Numerical simulation reveals the pressure of different yarn channel cross-sections and yarn surface with the increase in the inlet pressure. When the inlet pressure is higher, the pressure spreading to each section of the yarn channel is also higher, and the greater the pressure difference near the inner wall and yarn axis, thereby creating an easier hold for the yarn and then cause its steady movement and effective functioning as wrapping fibers. Furthermore, the velocity along the $x-, y$-, and $z$-axes of the four lines on the yarn surface are revealed. No significant difference is observed in the trends of the four lines; however, velocity and velocity fluctuation are higher under a higher inlet pressure.

(4) Experiment result indicates that the hairiness index of vortex-nozzle-spun yarns is less than those of conventionally spun yarns under different air pressure values. The hairiness index under 0.2-MPa air pressure is less than those under other air pressure values. With increasing air pressure, the vortex nozzle has a more obvious effect on reducing hairiness at less than 0.2 MPa. Beyond 0.2 MPa, the yarn hairiness number increases. Swirl nozzle increase the number of short hairiness slightly, which makes yarn feel fuller. It is also deteriorate yarn strength and evenness, but the difference is not obvious.

(5) Numerical simulation and experiment results indicate that a high inlet pressure creates a more significant effect of reducing hairiness. However, if the inlet pressure is remarkably high, the yarn structure may be easily blown away and loosened, which will cause significant loss of fibers and will influence yarn quality. Thus, an air pressure of $0.2 \mathrm{MPa}$ is clearly sufficient 
in significantly reducing yarn hairiness, and operating the nozzle at a low air pressure is also economical. This work envisions extending its future investigations on the other important factors and interactive efects of these factors to conduct other comprehensive research.

\section{ACKNOWLEDGEMENTS}

The authors are grateful for the financial supported by Prospective Industry-university-research Project of Jiangsu Province (BY2016022-14) and the Fundamental Research Funds for the Central Universities (No. JUSRP51301A).

\section{REFERENCES}

[1] Stalder, H., Rusch, A., Compact spinning wins market acceptance, In: International Textile Bulletin-English Edition, 2002, 48, 1, 42-43

[2] Cheng, K.P.S., Yu, C., Compact spinning wins market acceptance, In: Textile Research Journal, 2003, 73, 4, 345-349

[3] Cheng, K.P.S., Li, C.H.L., JetRing spinning and its influence on yarn hairiness, In: Textile Research Journal, 2002 , 72, 12, 1079-1087

[4] Xia, Z., Xu, W., Zhang, M., Reducing ring spun yarn hairiness via spinning with a contact surface, In: Fibers and Polymers, 2012, 13, 5, 670-674

[5] Qiu, H., Zhang, Y., Xu, Z.L., A novel method to reduce hairiness level of ring spun yarn, In: Fibers and Polymers, 2012, 13, 1, 104-109

[6] Qiu, H., Luan, Q., Jiang, H., Effect of airway angle of a swirl nozzle on performance of ring-spun yarn, In: Industria Textila, 2016, 67, 1, 10-16

[7] Rengasamy, R.S., Patanaik, A., Anandjiwala, R.D., Simulation of airflow in nozzle-ring spinning using computational fluid dynamics: study on reduction in yarn hairiness and the role of air drag forces and angle of impact of air current, In: Textile Research Journal, 2008, 78, 5, 412-420

[8] Rengasamy, R.S., Kothari, V.K., Patnaik, A., Airflow simulation in nozzle for hairiness reduction of ring spun yarns. Part I: Influence of airflow direction, nozzle distance, and air pressure, In: Journal of the Textile Institute, 2006, 97, 1, 89-96

[9] Han, C., Xue, W., Cheng, L., Theoretical analysis on the yarn twist mechanism of self-twist jet vortex spinning, In: Textile Research Journal, 2016, 86, 9, 911-918

[10] Kim, S E., Choudhury, D., A near-wall treatment using wall functions sensitized to pressure gradient, In: Separated and complex flows-1995, 1995, 85, 1, 273-280

[11] Han, C., Xue, W., Cheng, L., Comparative analysis of different jet vortex spinning hollow spindle groove structures on yarn mechanism and yarn properties, In: Textile Research Journal, 2016, 86, 19, 2022-2031

[12] Li, M., Yu, C., Shang, S., Effect of vortex tube structure on yarn quality in vortex spinning machine, In: Fibers and Polymers, 2014, 15, 8, 1786-1791

\section{Authors:}

\section{JIANG YAN, HUA QIU}

Jiangnan University, Faculty of Key Laboratory of Eco-Textiles, Ministry of Education,

Wuxi-214122, Jiangsu-China

e-mail: 849267023@qq.com, qiuhua@jiangnan.edu.cn

\section{Corresponding author:}

HUA QIU

e-mail: qiuhua@jiangnan.edu.cn 


\title{
The impact of intellectual capital, organizational capabilities and innovation on firm performance of textile sector: a moderating effect of GSP Plus
}

DOI: $10.35530 / 1 T .070 .06 .1632$

\author{
MUHAMMAD ZIA-UR-REHMAN \\ SAJJAD AHMAD BAIG \\ MUHAMMAD ABRAR \\ MUHAMMAD HASHIM
}

\author{
FIZA AMJAD \\ IRFAN AHMAD BAIG \\ MUHAMMAD USMAN
}

\section{ABSTRACT - REZUMAT}

\begin{abstract}
The impact of intellectual capital, organizational capabilities, and innovation on firm performance
\end{abstract} of textile sector: a moderating effect of GSP Plus

\begin{abstract}
The objective of this study was to investigate the relationship between intellectual capital, organizational capabilities, Innovations and firm performance through the moderating role of GSP Plus status. The findings show that intellectual capital, organizational capabilities, and Innovations have a significant impact on firm performance. Additionally, the GSP Plus moderates the relationship between intellectual capital and firm performance. The GSP Plus also moderates the relationship between Innovation and firm performance. However, GSP Plus does not moderate the relationship between organizational capabilities and firm performance. The findings of this study would guide the textile exporters to understand how to enhance a firm's performance by giving preference to the intellectual capitals, Organizational Capabilities and Innovations and how to utilize the GSP Plus status effectively.
\end{abstract}

Keywords: GSP Plus, intellectual capital, performance, Organizational Capabilities

Impactul capitalului intelectual, capacităților organizaționale și inovării asupra performanței firmelor din sectorul textil: un efect de moderare GPS Plus

Obiectivul acestui studiu a fost de a investiga relația dintre capitalul intelectual, capacitățile organizaționale, inovarea și performanța firmelor prin rolul moderator al GSP Plus. Rezultatele arată că inovarea, capitalul intelectual şi capacitățile organizaționale au un impact semnificativ asupra performanței firmei. În plus, GSP Plus moderează relația dintre capitalul intelectual și performanța firmelor. GSP Plus moderează, de asemenea, relația dintre inovare și performanța firmelor. Totuși, GSP Plus nu moderează relația dintre capacitățile organizaționale și performanța firmelor. Rezultatele acestui studiu îi vor îndruma pe exportatorii de textile să înțeleagă cum să îmbunătățească performanța unei firme, acordând importanță capitalului intelectual, capacităților organizaționale și inovării și cum să utilizeze în mod eficient GSP Plus.

Cuvinte-cheie: GPS Plus, capital intelectual, performanță, capacități organizaționale

\section{INTRODUCTION}

The oldest, biggest, and commercial industry in the world is the textile and clothing industry. Most of the textile industries throughout the world are labor-intensive. The textile sector of Asia had always been grabbing the attention of thewell-developed countries of the west. Pakistan is the principal exporter of cottonbased fabric, Fabric products, and cotton. At present, Pakistani fabric products have been encountering challenging competition by major competitors like India, Bangladesh, and China [1]. Textile exports value of China is about US\$ 45 million and of Pakistan US\$ 13.8 million. It is a major source of employment generation in Pakistan.

"Generalized System of Preferences is a mechanism of a formalized system through which the developed countries like the USA and the European Union give relaxation in tariffs to the underdeveloped countries, which have the membership of WTO to export their goods to Europe or the USA". According to Kaufmann \& Schneider [2], intellectual capital has defined in different ways, such as, there is concurrence about the value creation of IC and its supports in creation of competitive advantages in organizations. Authors define organizational capabilities as "Capabilities are complex bundles of skills and knowledge embedded in generational processes" [3]. Innovation was classified into five types, namely, products, processes, technological, markets, and organizational innovation. This study considers two dimensions of innovation: technological innovation and administrative innovation. This study is designed to examine whether the possibilities and challenges, placed on the GSP+ status have any influence on the Performance of the textile industry of Pakistan? What sorts of the role will the GSP+ status will play in the fulfillment of the textile industry? Moreover, how the development of the 
textile sector can be achieved by focusing on intellectual capital, organizational innovation, and capabilities? The primary objectives are comprehensive to study the role of GSP Plus status on the performance of the Pakistani textile industry.

\section{LITERATURE REVIEW}

\section{Intellectual Capital (IC)}

According to Cohen \& Kaimenakis [4], IC is the integration of internal and external knowledge of the firms that provide a viable competitive advantage, if it is undertaken by the well-managed firm. According to Tseng \& James Goo [5], intellectual capital and the firm market value have a positive and significant effect on financial performance. Australian banks which heavily invest in the components of intellectual capital are more profitable than others who have low investment in IC [6]. The empirical evidence suggests that profitability, market valuation and productivity of the company in South Africa would be explained by the performance of its intellectual capital [7].

Hypothesis 1: There is a positive and significant relationship between the intellectual on firms performance.

\section{Organizational Capability}

Authors define organizational capabilities as "Capabilities are complex bundles of skills and knowledge embedded in generational processes [3]". According to the functional definition of organizational capability, there are seven dimensions of organizational capabilities, i.e., learning, R\&D, resource allocation, marketing, organizing, structural planning, and manufacturing capabilities [8]. The resourcebased perspective of the firm contends that capabilities are supportive for enhanced quality, and decreased irregularity, are the foundation of the upper hand [9].

Hypothesis 2: There is a positive and significant relationship between organizational capabilities and firms' performance.

\section{Innovation}

Innovation was classified into five types, namely, products, processes, technological, markets, and organizational innovation. This study considers two dimensions of innovation: technological innovation and administrative innovation. The new product and technological development had a significant impact on the performance of firms [10].This study determined the importance of innovation for the survival of businesses in today's competitive world and their potential growth with a particular example of organic textile. The findings of this study would help the countries of the developing world, exclusively Pakistan, to successfully exploit organic textile opportunities for creating competitive advantage and growth available in the international markets [11-12]. The scholar suggests that innovation is used as a competitive strategy by Pakistani respondents to compete globally. The main source of technical innovation is the internal innovation in firms Pavitt [13] and typical internal innovation depends on the capability of workers. Administrative innovations can be described as the new techniques, rules and structure forms [14]. Innovation is one of the most crucial drivers of longrun success in business, notably in rapidly changing markets. On the basis of the literature review, the study develops the following hypothesis.

Hypothesis 3: There is a positive and significant relationship between innovation and firms' performance.

\section{GSP Plus and Firm Performance}

Internationalization is an important growth strategy for the firms whose home country market is limited, though it enables the firms to realize economies of scale and scope Caves \& Caves [15], increase their market power [16]. According to Pasha [17], European Union's award, the status of Generalized System of Preferences (GSP) to Pakistan allow the duty-free access for several eligible categories of Products, manufactured in Pakistan which were exported to the EU market. Scholer suggested that the Pakistani industry would invest in capacity building for their employees to increase their performance[18].

Many studies show that opportunities of international trade had a positive impact on firms' performance. Opportunities for import and export are more productive than non-export and non-import, and they were more versatile and more productive as compared to their own performance when they were not importer and exporter [19].

H4: GSP plus moderates the relationship between structural capital and firms' performance.

H5: GSP plus moderates the relationship between organizational capabilities and organizational performance.

H6: GSP plus moderates the relationship between innovations and firms' performance

\section{METHODOLOGY}

\section{Data types and research period}

From the literature, it was shown that the most frequently used technique for data collection in quantitative research methodology is surveyed questionnaire. Keeping in mind all constraints (cost, time, and population), mail survey and self-administered questionnaire were adopted for the data collection, from the textile companies of Pakistan. The targeted population for this study is the executives, General Managers, Marketing Managers, Mill Managers, Finance Managers and other managers of Pakistani textile companies; and these executives and managers have sufficient knowledge and access to the internet. The primary data were collected from the textile sector of Pakistan. The respondents were selected from four categories of textile sector, i.e., Spinning, Weaving, Processing, and Garments from two provinces of Pakistan, i.e., Sindh and Punjab. All necessary details about textile companies were 
taken from these associations' members' directory. Multistage sampling technique will be used to select respondents, and the sample size is around 450 . After a brief overview of the literature, a developed questionnaire was selected for the study that was the most relevant to this research objective. The measure was adjusted in the context of the study. The current study dealt with innovation, organizational capabilities, firm performance and GSP plus. Prior to the start ofthe survey, a pilot study was conducted. The main purpose of the pilot study is to developan understanding of the respondents about the questions, used in survey andto implore response for the improvement of the measuresand determine the time, required for the completion of a survey by the respondents.

\section{Data analysis}

AMOS software was used to find out the relationship between endogenous and exogenous constructs. The study used confirmatory factor analysis to assess the reliability and validity of measures.

\section{Confirmatory Factor Analysis}

The measure, used for human capital and structural capital consists of eight items, and for customer capital 6 items: for each uses a seven-point Likert-scale to obtain responses, ranging from 7 for strongly agreed to 1 for strongly agreed. Although the instruments were previously tested for validity and reliability, and the reliability coefficients for human capital was $\alpha=0.643$, for structural capital $\alpha=0.754$, and for customer capital 0.677 . The organizational capability has seven dimensions with 30 items: the results of reliability coefficients for Learning Capability $\alpha=0.746$, R\&D $\alpha=0.791$, Organizing capability $\alpha=0.828$. Marketing Capability $\alpha=0.782$, Manufacturing Capability $\alpha=0.700$ and for Strategic Planning $\alpha=0.792$. The Innovation constructs have two dimensions, e.g., technical innovation and administrative innovation was represented by 6 items. The Reliability analysis shows that reliability coefficients for technological innovation were $\alpha=0.70$, and for administrative innovation $\alpha=0.758$. To measure the performance, the study used an already developed measure scale by Khalique et al. [20]. Subjective measures can be consistent with objective measures, indicated by the previous researchers. The reliability coefficient for measuring performance was $(\alpha=0.816)$. For better understanding, loadings that are above 0.70 are considered. All items loaded on their respective factor loading and most of the loadings above 0.70 as shown in the table. The results of CFA suggest that $(\mathrm{CMIN} / \mathrm{DF}=4.53, \mathrm{RMESA}=0.051$, $\mathrm{CFI}=0.939, \mathrm{TLI}=0.914$ and $\mathrm{IFI}=0.939)$ the model was accepted without any modification. As the results of CFA exhibited, a strong Loading and the model showed a good model fit for Data. The fit indices of the model show that related to the suitability of the fit raised $R M E S A$ and $x^{2}$.

\section{Model Testing}

ASEM was used to test the direct path model and the hypnotized moderating relationship.

\section{Direct Path Testing}

This study used SEM to test the model, firstly examine the direct relationship between Intellectual capital and firm performance, organizational capability and firm performance and also the relationship between innovation and firm performance. According to the results of SEM, the path between intellectual capital and firm performance is positive and significant with positive $\beta$ value 0.51 and $p>0.05$. The results of AMOS are $(\beta=0.51, p=000)$. These findings support the H1. The results demonstrate that organizational capabilities positively and significantly contribute to firm performance $(\beta=0.149, p=0000)$. These results showthat 1 percent change in organizational capabilities contributes 14.9 percent in firm performance, $\mathrm{H} 2$ is accepted. The results also show that innovation positively and significantly impacts firm performance $(\beta=0.172, p=0000)$. Beta value shows that 1 percent change in innovation activities leads to $17.2 \%$ change in firm performance. So the H3 is accepted.

\section{Table 1}

SUMMARY OF INITIAL PATH MODEL ANALYSIS

\begin{tabular}{|c|c|c|c|c|}
\hline \multicolumn{1}{|c|}{ Indicators } & $\begin{array}{c}\text { Estimate/ } \\
\boldsymbol{\beta}\end{array}$ & S.E. & C.R. & $\mathbf{P}$ \\
\hline PERORM $\leftarrow$ OC & 0.511 & 0.052 & 11.892 & 0.000 \\
\hline PERORM $\leftarrow$ Innovation & 0.172 & 0.044 & 4.212 & 0.000 \\
\hline PERORM $\leftarrow$ IC & 0.149 & 0.058 & 3.735 & 0.000 \\
\hline R & 0.514 & \multicolumn{3}{|c}{} \\
\hline
\end{tabular}

\section{Intellectual capital and firm performance}

The product term of intellectual capital ${ }^{*}$ GSP plus was showing a positive and significant impact on firm performance $(\beta=0.169, p=0.051)$. Hence, it supports the fourth hypothesis; the results indicate that the model described $63 \%$ variance in firm performance. The resultssupport the relationship between the interaction term of IC*GSP and firm performances. H4 is accepted.

Table 2

\begin{tabular}{|c|c|c|c|c|}
\hline Indicators & $\begin{array}{c}\text { Path } \\
\text { coefficients }\end{array}$ & S.E. & C.R. & $\mathbf{P}$ \\
\hline IC & -0.299 & 0.233 & -1.285 & 0.199 \\
\hline GSP & 0.128 & 0.045 & 2.823 & 0.005 \\
\hline Int_1 & 0.169 & 0.220 & 0.768 & 0.051 \\
\hline $\mathrm{R}^{2}$ & \multicolumn{4}{|c|}{0.63} \\
\hline
\end{tabular}




\section{Organizational Capabilities}

The product term of $\mathrm{OC}^{*} \mathrm{GSP}$ plus was showing a positive but insignificant impact on firm performance $(\beta=0.032, p=0.995)$. Hence, it does not support the fourth hypothesis as the results indicate that the model described $72 \%$ variance in firm performance. The results show that the relationship between the interaction term of IC*GSP and firm performances is positive but insignificant. H5 is rejected.

Table 3

ESTIMATED SEM RESULTS OF PRODUCT TERMS OF OC*GSP

\begin{tabular}{|c|c|c|c|c|}
\hline Indicators & Estimates & S.E. & C.R. & p \\
\hline OC & 0.505 & 0.168 & 2.999 & 0.003 \\
\hline GSP & 0.650 & 0.162 & 4.015 & 0.000 \\
\hline Int_1 & 0.002 & 0.032 & 0.056 & 0.955 \\
\hline R $^{2}$ & \multicolumn{4}{|c|}{0.72} \\
\hline
\end{tabular}

\section{Innovation}

In the progress of the organization, the role of innovation is crucial and stimulating the standards of living. This section explores two significant types of innovation, i.e., technical innovation and administrative innovation of textile industry. The product term of Innovation*GSP plus was showing a positive and significant impact on firm performance $(\beta=0.087$, $p=0.016)$. Hence, it does not support the fourth hypothesis as the results indicate that the model described $61 \%$ variance in firm performance. The significance value $p=0.016$ and beta value 0.087 which show that the relationship between interaction term of IC*GSP and firm performances positive and significant. $\mathrm{H} 6$ is accepted.

$\mathrm{R}^{2}$ was 0.610 . The interaction term (GSP*innovation) was significant. All the results approved that status of GSP plus moderated the relationship between innovation and firm performance. These results were also proved with a model run by employing AMOS SEM. Moreover, hence, the study accepts the hypothesis that GSP plus moderate the relationship between innovation and firms' performance.

Table 4

ESTIMATED REGRESSION RESULTS OF PRODUCT TERM OF INNOVATION*GSP

\begin{tabular}{|c|c|c|c|c|}
\hline Indicators & Estimates & S.E. & C.R. & p \\
\hline Innovation & -0.210 & 0.181 & -1.164 & 0.244 \\
\hline GSP & 0.350 & 0.181 & 1.929 & 0.054 \\
\hline Int_1 & 0.087 & 0.036 & 2.398 & 0.016 \\
\hline R $^{2}$ & \multicolumn{5}{|c|}{0.61} \\
\hline
\end{tabular}

\section{DISCUSSION}

The study aimed to explore the association between IC, OC, Innovation, firm performance and the moder- ating role of GSP Plus. The findings suggest that the combination of three elements of intellectual capital waspositively contributed to the performance of the textile industry in Pakistan. The findings of this study were approved by previous studies. The organizations, invested in intellectual capital especially in human capital are performed well. There is no doubt that intellectual capital is considered one of the critical factors and a key driver for organizational performance [20-21]. Pakistan has not well-organized its knowledge ofthe economy. Pakistan does not rank highly among the world's knowledge-intensive nations [22]. Chen, Moghaddas, Hoppel, \& Lesnefsky [23] and Miller \& Wurzburg [24] also have similar findings; they concluded that intellectual capital positively and significantly contributes to firms' performance. It is also found that intellectual capital can be further increased through capacity building of employees. However, formal investment in training and development among Pakistani textile industries, especially in SMEs is miserably low. The results show that organizations that understand the importance of GSP Plus and willing to invest in intellectual capital would perform better. In the history, Sri Lanka benefited from the GSP plus scheme that extended trade incentive to the textile sector to enter into European Union (EU) market. According to Ekanayake [25], he suggested that companies perform better under GSP era and increase their exports. These studies provide evidence that GSP plus Status help organizations to enhance their performance. According to Qureshi \& Jalbani [26], technological capacity-building and financial assistance help organizations to move toward the global expansion in different sectors of Pakistan. The GSP plus status encourages globalization of their operations and boosts their share of export in the world market. When the value of GSP plus increased its effects positively on the relationships between Intellectual Capital and firms' performance. While the combination of Organizational Capabilities positively and significantly affectsfirms' performance. According to Grewal \& Slotegraaf [27], organizational capabilities empower a firm to perform well, and OC lives in organizational process and schedules that are hard to imitate. Capabilities are profoundly established in these procedures and accordingly are inserted inside of firms in the mindboggling cross section of interconnected activities that take subsequent administrative choices after some time. Danneels [28] also reveals similar findings; he concluded that current capabilities might serve as influences, focusing on the development of new ones for sustaining the firms' performance. In general, capabilities were key determinants of firms'performance; there was a positive and significant relationship between OC and firm performance [29]. The results were partially supported by Autio, Sapienza, \& Almeida [30], as they concluded that normally capabilities are passively linked with performance and with international trade opportunities. In addition, it was also interesting results in short run that organizations investment on the capabilities in 
the initial stage of internationalization (international trade opportunities) might have an insignificant effect on firms' performance and might be reduced the chances of a firm's performance in short run. Also Sapienza, Autio, George, \& Zahra [31] stated that, when firms were starting to develop capabilities, the organization was fragile in early stages and these new capabilities became more effective, workable and profitable in the long run. This study hypothesized that innovations positively correlated with firms' performance. Findings of the study reveal that innovations positively and significantly affect firm performance. Gunday, Ulusoy, Kilic, \& Alpkan [32] also found that innovations positively affectthe organizational performance of manufacturing industries. The effect of the knowledge management capabilities on firm performance isfully mediated by innovations [33]. They concluded that innovation significantly and positively affects firms' performance of the textile sector. Qiao, Ju, \& Fung [34], they investigated that innovation was found a positive effect on firms' performance at SMEs. According to Soto-Acosta, Popa, \& Palacios-Marqués [35], innovations positively contributed to firms' performance. Another researcher Gunday et al. [32] studied that different types of innovation had a significant positive effect on firms' performance of manufacturing industries. Ceylan [36] found that Administrative innovation activities were the main forces for implementing the process of innovation and marketing innovation, resulting in more innovative products. Subsequently, product innovation would enhance firms' innovation performance. The previous studies provide support to the findings. The organizational supports for the advancement of technical capabilities, firm performance can be increased through organizational innovations and technical capabilities, used in processes and products [37]. Alamdari \& Fagan [38] examine the linkage between innovation in production and firms' performance. Previous studies explore that lead-time and innovative product development behavior and the process of production positively impactedon the firm performance. According to Cingöz \& Akdoğan [39], in an ever-changing business environment, the innovative behavior of production positively links the firm performance, which is considered as an important source that leads the organization toward success. Another scholar suggested that superior firm performance can be achieved through organizational innovation and technological capabilities for the products and processes [37].

According to Miller [40], mostly the organizations adapt technological innovation for improving firms' performance by attaining the competitive advantages in their markets. However, the technological innovation required the support of marketing and organizational innovation. Walker [41] stated that a sustainable adoption of both technical and administrative were more efficient in helping the organization to sustain and improve their performance as compared to one type of innovation in an organization. Although innovation literature and our results were unable to describe a decision whether a specific innovation type was likely to provide more or less impact on the performance of manufacturing units, so it can be concluded that the different types of innovations influence each other and need to be implemented in conjunction. Therefore, for boosting exports, it is suggested to implement both types of innovations are in conjunction.

This result also enhances the innovation literature by proving that another significant factor that international trade opportunity strengthens the relationship between innovation and performance of organizations. The findings were supported by the findings of Kafouros, Buckley, Sharp, \& Wang [42], who concluded that the impact of the different innovation practices on the organizational performance is statistically insignificant for those firms, having fewer trade opportunities internationally.

\section{CONCLUSION}

This study was designed to examine whether the opportunities and challenges, placed by the GSP+ status had any influence over the Performance of the textile industry. What sorts of role would the GSP+ status play in the performance of the textile industry? Moreover, how the development of Textile sector could be achieved by focusing on the intellectual capital and Organizational innovation and capabilities. The main objectives were to study the role of GSP Plus status on the performance of Pakistan's Textile industry comprehensively. For studyingthe role of GSP Plus status in the performance of Pakistan's Textile industry comprehensively, we studied the capability of a Textile sector of Pakistan for getting the benefits of GSP Plus status; investigate the strength of Textile sector regarding the development of intellectual capital to exploit GSP Plus. To explore how the innovations can be important to develop the textile sector to get benefits of GSP Plus status.

This study measures the intellectual capital by the value of Human capital, structural capital and, customer capital. According to the results, there was a positive relationship with firm performance. The current study measures Organizational Capability through seven dimensions: Learning Capability, Marketing Capability, R\&D Capability, Resource Allocation Capability, Manufacturing Capability, Organizing Capability, and Strategic Capability. According to the results, organizational capabilities showeda positive relationship with the firms' performance. However, after introducing GSP plus as a moderator, the relationship became insignificant. In today's dynamic business environment, organizations need to focus equally on all the organizational capabilities, mostly organizations focused on marketing capabilities and ignored all other OC. They must align all type of capabilities with business strategies to be competitive in the global market. We measure innovation through two dimensions: administrative innovation and firms' performance. According to results of regression analysis showed that there was 
a positive and significant relationship between Innovation and firm performance. So, for boosting exports, it is suggested to implement both types of innovations in conjunction. This study also examined the impact of innovation on textile performance in the context of the GSP Plus for Pakistani textile organizations. The results indicated that the interaction term of innovation*GSP had a positive and highly significant impact on the dependent variable (firm performance).

\section{Limitation of study}

This study also has some limitations. The current study collected data from the overall textile sector of Pakistan without specifying any industry like Garment, Processing, Weaving, Spinning, and Knitting. The GSP plus status would help to improve the export performance of the textile sector of Pakistan. Therefore, there is a need to consider export-oriented textile industries to boost export performance. We should also consider other manufacturing industries, which come under the scope of GSP plus. Secondly, the current study utilized crosssectional data, which makes it problematic to explain complete cause-effect relationships between constructs. Longitudinal research in the future is required; which make it possible to understand inferences. There might be other variables, which could boost the export performance of manufacturers through GSP plus scheme like HR Practices, learning orientation, Organizational Culture, TQM Practices, and Knowledge Exchange. The main advantage of GSP plus status is to improve the export performance of organizations; however; the current study worked on overall organizational performance. Therefore, future research must focus on export performance in order to exploit completely an organizational performance.

\section{REFERENCES}

[1] Shahbaz, M., Measuring economic cost of electricity shortage: current challenges and future prospects in Pakistan, 2015

[2] Kaufmann, L., Schneider, Y., Intangibles: a synthesis of current research, In: J. Intellect. Cap., 2004, 5, 3, 366-388

[3] Helfat, C.E., Peteraf, M.A., The dynamic resource-based view: Capability lifecycles, In: Strateg. Manag. J., 2003, 24, 10, 997-1010

[4] Cohen, S., Kaimenakis, N., Intellectual capital and corporate performance in knowledge-intensive SMEs, In: Learn. Organ., 2007, 14, 3, 241-262

[5] Tseng, C., James Goo, Y., Intellectual capital and corporate value in an emerging economy: empirical study of Taiwanese manufacturers, In: R\&D Manag., 2005, 35, 2, 187-201

[6] Pulic, A., VAIC ${ }^{T M}$ - an accounting tool for IC management, In: Int. J. Technol. Manag., 2000, 20, 5-8, 702-714

[7] Firer, S., Mitchell Williams, S., Intellectual capital and traditional measures of corporate performance, In: J. Intellect. Cap., 2003, 4, 3, 348-360

[8] Yam, R.C.M., Guan, J.C., Pun, K.F., Tang, E.P.Y., An audit of technological innovation capabilities in Chinese firms: some empirical findings in Beijing, China, In: Res. Policy, 2004, 33, 8, 1123-1140

[9] Barney, J., Firm resources and sustained competitive advantage, In: J. Manage., 1991, 17, 1, 99-120

[10] Mumford, M.D., Managing creative people: Strategies and tactics for innovation, In: Hum. Resour. Manag. Rev., 2000, 10, 3, 313-351

[11] Safeer, A.A., Basit, A., Abrar, M., Zia-Ur-Rehaman, M., Baig, S.A.,Hashim, M., Export competitiveness analysis of Pakistan garments industry based on GEM Model, In: Industria Textila, 2018, 69, 3, 219-229, https://doi.org/ 10.35530/IT.069.03.1457

[12] Abrar, R., Safeer, M.,Baig, A.A., Bashir, S.A., Amjad, F., Shabbir, R., Innovation is creating competitive advantage: a perspective to improve the organic textile products for business growth, In: Industria Textila, 2019, 70, 2, 147-153, https://doi.org/10.35530/IT.070.02.1644

[13] Pavitt, K., What we know about the strategic management of technology, In: Calif. Manage. Rev., 1990, 32, 3, $17-26$

[14] Evan, W.M., The organization-set: Toward a theory of interorganizational relations, In: Approaches to Organ. Des., 1966, 173-191

[15] Caves, R.E., Multinational enterprise and economic analysis, Cambridge university press, 1996

[16] Kogut, B., Designing global strategies: profiting from operational flexibility, In: Readings Int. Business, MIT Press. Cambridge, MA, 1993, 195-213

[17] Pasha, H.A., GSP plus status and compliance of labor standards, Friedrich-Ebert-Stiftung, 2014

[18] Wagan, S.M., Export boost of Textile Industry of Pakistan by availing EU's GSP Plus, In: J. Econ. Libr., 2015, 1, $1,18-27$

[19] Wagner, J., German multiple-product, multiple-destination exporters: Bernard-Redding-Schott under test, In: University of Lüneburg Working Paper Series in Economics, 2012

[20] Khalique, M., Shaari, N., Abdul, J., Isa, A.H.B.M., Intellectual capital and its major components, 2011

[21] Bontis, N., Intellectual capital: an exploratory study that develops measures and models, In: Manag. Decis., 1998, $36,2,63-76$ 
[22] Bontis, N., National intellectual capital index: a United Nations initiative for the Arab region, In: J. Intellect. Cap., 2004, 5, 1, 13-39

[23] Chen, Q., Moghaddas, S.,Hoppel, C.L., Lesnefsky, E.J., Reversible blockade of electron transport during ischemia protects mitochondria and decreases myocardial injury following reperfusion, In: J. Pharmacol. Exp. Ther., 2006, 319, 3, 1405-1412

[24] Miller, R., Wurzburg, G., Investing in human capital, In: OECD Obs., 1995, 193, 16-20

[25] Ekanayake, N., Determinants of External Demand for Textiles and Garments of Sri Lanka, In: Staff Stud., 2016, 43, 1-2

[26] Qureshi, J.A., Jalbani, A.A., The role of public institutional support for globalization of pakistani companies, In: Pakistan Bus. Rev., 2017, 18, 4, 813-828

[27] Grewal, R., Slotegraaf, R.J., Embeddedness of organizational capabilities, In: Decis. Sci., 2007, 38, 3, 451-488

[28] Danneels, E., The dynamics of product innovation and firm competences, In: Strateg. Manag. J., 2002, 23, 12, 1095-1121

[29] Day, G.S., The capabilities of market-driven organizations, In: J. Mark., 1994, 58, 4, 37-52

[30] Autio, E., Sapienza, H.J., Almeida, J.G., Effects of age at entry, knowledge intensity, and imitability on international growth, In: Acad. Manag. J., 2000, 43, 5, 909-924

[31] Sapienza, H.J., Autio, E., George, G., Zahra, S.A., A capabilities perspective on the effects of early internationalization on firm survival and growth, In: Acad. Manag. Rev., 2006, 31, 4, 914-933

[32] Gunday, G., Ulusoy, G., Kilic, K., Alpkan, L., Effects of innovation types on firm performance, In: Int. J. Prod. Econ., 2011, 133, 2, 662-676

[33] Hsu, I.C., Sabherwal, R., From intellectual capital to firm performance: the mediating role of knowledge management capabilities, In: IEEE Trans. Eng. Manag., 2011, 58, 4, 626-642

[34] Qiao, P., Ju, X., Fung, H.G., Industry association networks, innovations, and firm performance in Chinese small and medium-sized enterprises, In: China Econ. Rev., 2014, 29, 213-228

[35] Soto-Acosta, P., Popa, S., Palacios-Marqués, D., E-business, organizational innovation and firm performance in manufacturing SMEs: an empirical study in Spain, In: Technol. Econ. Dev. Econ., 2016, 22, 6, 885-904

[36] Ceylan, C., Commitment-based HR practices, different types of innovation activities and firm innovation performance, In: Int. J. Hum. Resour. Manag., 2013, 24, 1, 208-226

[37] Camisón, C., Villar-López, A., Organizational innovation as an enabler of technological innovation capabilities and firm performance, In: J. Bus. Res., 2014, 67, 1, 2891-2902

[38] Alamdari, F., Fagan, S., Impact of the adherence to the original low-cost model on the profitability of low-cost airlines, In: Transp. Rev., 2005, 25, 3, 377-392

[39] Cingöz, A.,Akdoğan, A.A., An empirical examination of performance and image outcome expectation as determinants of innovative behavior in the workplace, In: Procedia-Social Behav. Sci., 2011, 24, 847-853

[40] Miller, W.L., Innovation for business growth, In: Res. Manag., 2001, 44, 5, 26-41

[41] Walker, R.M., Innovation and organisational performance: Evidence and a research agenda, In: Adv. Inst. Manag. Res. Pap., 2004, 002

[42] Kafouros, M.I., Buckley, P.J., Sharp, J.A., Wang, C., The role of internationalization in explaining innovation performance, In: Technovation, 2008, 28, 1-2, 63-74

\section{Authors:}

MUHAMMAD ZIA-UR-REHMAN ${ }^{1}$, SAJJAD AHMAD BAIG ${ }^{1}$, MUHAMMAD ABRAR², MUHAMMAD HASHIM $^{1}$, FIZA AMJAD ${ }^{1}$, IRFAN AHMAD BAIG ${ }^{3}$, MUHAMMAD USMAN ${ }^{1}$

${ }^{1}$ National Textile University, Faisalabad, Pakistan

2Lyallpur Business School, GC University Faisalabad, Pakistan

${ }^{3}$ Muhammad Nawaz Sharif University of Agriculture, Multan Pakistan

Corresponding author:

SAJJAD AHMAD BAIG

e-mail: sajjad.baig@hotmail.com 


\title{
The specific elements of strategic human resources management for competitive business development
}

DOI: $10.35530 / I T .070 .06 .1749$

\author{
MARIAN NASTASE \\ NICOLAE BIBU \\ ANCA-IOANA MUNTEANU
}

\begin{abstract}
ILEANA MIRCIOI (VALIMAREANU) MARGARETA STELA FLORESCU
\end{abstract}

\section{ABSTRACT - REZUMAT}

\section{The specific elements of strategic human resources management for competitive business development}

The current business environment, characterized by a high degree of uncertainty and unpredictability, has led to a sharp increase in competitiveness. The key to the success of any organization in the current period lies in its human resources, the only ones capable of identifying unique and creative solutions to face the threats existing in the environment and to seize existing opportunities. Emphasis should be placed on transforming them and the Human Resources Department into true strategic partners of organizations and on implementing a strategic human resources management.

The present paper aims to identify the extent to which, at the level of the organizations from the Western Region of Romania, such elements have been adopted that will contribute to their competitive development. The textile industry is an important sector that has powerful impact over the economic and social development of a region or country. Its long term development depends not only on the business characteristics, but especially on the strategic decisions and approaches, with direct results in terms of profitability, jobs creation and integration with other economic sectors. Therefore, in our research we introduced in the sample companies from this dynamic field.

The results of the study showed that the tendency of appreciation of their existence in organizations is wide spread. In the same time, it was confirmed that the existence of a strategic human resources management in organizations is conditioned by the strategic use of human resources practices, in the long term, in order to contribute to the achievement of the general business objectives. Also, in order for the human resources strategy to bring its contribution to the realization of the general business strategy, there is a need for human resources activities that are aligned with the company's objectives.

Without claiming that the study carried out is an exhaustive one, we consider that the information presented are unique and can be useful for those interested.

Keywords: human resources, strategic human resources practices, business strategy, human resources strategy, strategic human resources management, competitive advantage.

\section{Elemente specifice ale managementului strategic al resurselor umane pentru dezvoltarea competitivă a firmelor}

Mediul de afaceri actual, caracterizat printr-un grad ridicat de incertitudine și imprevizibilitate, a dus la o creștere accentuată a competitivității. Cheia succesului oricărei organizații în perioada actuală constă în resursele sale umane, singurele capabile să identifice soluții unice și creative pentru a face față amenințărilor existente în mediu și să profite de oportunitățile existente. Ar trebui pus accentul pe transformarea lor și a Departamentului Resurse Umane în adevărați parteneri strategici ai organizațiilor și pe implementarea unui management strategic al resurselor umane.

Lucrarea de față iș̦i propune să identifice măsura în care, la nivelul organizațiilor din Regiunea de Vest a României, au fost adoptate astfel de elemente care vor contribui la dezvoltarea competitivă a acestora. Industria textilă este un sector important, ce are un impact puternic asupra dezvoltării economice și sociale a unei regiuni sau țări. Dezvoltarea sa pe termen lung depinde nu doar de caracteristicile constructive ale companiilor, dar mai ales de abordările și deciziile strategice adoptate, cu rezultate directe în termeni de profitabilitate, creare de locuri de muncă și integrarea cu alte sectoare ale economiei. De aceea, în cercetarea noastră au fost introduse și companii din industria textilă, având în vedere dinamica acestora.

Rezultatele studiului au arătat că tendința de apreciere a existenței lor în organizații este larg răspândită. În același timp, s-a confirmat că existența unui management strategic al resurselor umane în organizații este condiționată de utilizarea strategică a practicilor de resurse umane, pe termen lung, pentru a contribui la realizarea obiectivelor generale ale afacerii. De asemenea, pentru ca strategia de resurse umane să își aducă contribuția la realizarea strategiei generale de afaceri, este nevoie de activități de resurse umane care să fie aliniate obiectivelor companiei.

Fără a pretinde că studiul efectuat este unul exhaustiv, considerăm că informațiile prezentate sunt unice și pot fi utile pentru cei interesați.

Cuvinte-cheie: resurse umane, practici strategice de resurse umane, strategie de afaceri, strategie de resurse umane, management strategic de resurse umane, avantaj competitiv 


\section{INTRODUCTION}

Gaining the competitive advantage is an essential objective of any organization. If achieving competitive advantage is a challenge for any organization, maintaining it is a real challenge, a goal that is quite difficult to achieve. In the process of formulating the overall strategy of an organization, it is necessary to carefully analyze the consequences that it has in determining and sustaining the competitive advantage.

To obtain a competitive advantage, it is necessary to consider a large number of situational variables. The most important ones are those regarding the human resources available to the respective organization.

An important source of competitive advantage is innovation having as main characteristic to have it and to use it over a long period of time. However, the source which mostly supports this goal is the human resources of an organization. Over time, employees have proven to be an inexhaustible source of creativity within a company, the only resource capable of ensuring competitiveness through innovation. The key to have competitiveness, the orientation of the industrial environment towards quality, is represented by the human resources of an organization in an era of rapid global changes.

Effectiveness of textile companies' strategies and policies will have directly impact in the productivity and quality of these organizations, influencing to the large extent their market share and profitability.

Consequently, its human resources are the foundation of any success of any organization. Only people, employees have new ideas, create new solutions about solving problems that inevitably arise, or about exploiting opportunities in the external environment. They are the ones who can make the difference through their thinking process, their modality to action and by the degree of involvement in the work processes.

Clark (1996) mentions that in the case of European nations there are three common elements of human resources management that go beyond national borders [1]:

- recognizing the importance of human resources as a source of competitive advantage;

- delegation of responsibility for human resources, the company and/or managers in the field;

- mutual integration and consolidation of human resources strategies and the general strategy.

Therefore, in the current business environment, in Romania, too, the focus should be on transforming the human resources and the Human Resources Department into true strategic partners of the organizations [2]. This is really important for the textile companies that hire many employees, especially women and where the competencies of workforce are the main asset for these organizations [3].

That consists to involve HR specialists in the strategic process at the organization level, to aligning the human resources strategy with the business strategy, to elaborate human resources practices that contribute to the achievement of the strategic objectives, and into doing the transition towards a strategic human resources management in any organization [4-5]. In the following part, we will focus on presenting the concept of strategic human resources management (SHRM), analyzing its evolution over time [6]. Later, we will try to identify its characteristics at the level of organizations in the Western Region of the country, based on our research.

\section{CRITICAL ANALYSIS OF THE EVOLUTION OF THE CONCEPT OF "STRATEGIC HUMAN RESOURCES MANAGEMENT" IN THE SPECIALIZED LITERATURE}

The turbulent, uncertain environment, with increasingly rapid changes, since the late 1970s, early 1980s, has led many researchers in the field to go beyond the boundaries of studying human resources management at the micro level, and turning their attention towards a strategic approach. It was the period when a new era began to emerge, that of the strategic management of human resources (SHRM). Walker (1980) provided a first pragmatic description of how human resource planning in a company could be used to ensure that human resources policies and practices were aligned with the organization's business strategy [7].

The first definition of SHRM was given by Devanna, Fombrun and Tichy in 1981 [8]. They support the existence of a relationship between the strategic management of human resources and the business strategy, considering that in order to play a strategic role, the Human Resources Department should be involved in establishing the organization's objectives. This action, in their opinion, leads to an increase in the company's performance.

Miles and Snow [9] were the first to argue that human resource management practices need to be aligned with other organizational activities, especially with strategic decisions within the organization. The two authors stressed that the human resources department should help to implement the different business strategies of the company.

In the same year, 1984, was published the first book focusing on the strategic human resources management [10]. In order to io illustrate what the strategic human resources management is and what is its role in an organization, the authors presented numerous examples of companies that have known the many benefits of its implementation.

Armstrong (2006) believes that the strategic management of human resources must try to strike an appropriate balance between the elements of the two subsystem categories of the organization, the "soft" and the "hard" [11]. All organizations aim to achieve a particular purpose and their main concern is to make sure that they have the resources they need to fulfill them, and that they use them effectively. But, according to Armstrong, they should also take into account the human considerations included in the concept of strategic human resources management (SHRM). 
Although studies have shown that most often the satisfaction of the elements related to the strategic hard management of human resources takes precedence over those in the soft category, he argues that it is particularly important to take into account in this process of planning the people with all their aspirations. According to Lefter, Marincas and Puia (2007), the strategic management of human resources has to take into account several aspects [12]:

- the existing predictions regarding the economic progress of the field of activity in which the company and clients operate;

- the position of the competitors (the technology they use, the selling price, the market share);

- the short, medium and long term sales policy;

- the uncertain level of sales evolution;

- the investment policy and technologies that will be implemented in the future;

- the production policy that the company will adopt in the future;

- the consequences of various factors that contribute to the emergence of new qualifications and changes in the management of the organization or in the planning of the work.

Uysal and Mayis (2014) approached SHRM through the perspective of the relation between employee performance and the performance of the organization, considering that the performance of the employees affects the performance of the company [13]. The two consider that the performance of the employees is the link between the SHRM and the overall performance of the company. Strategic human resources management aims to increase both employee performance and business performance. They consider that if the management of human resources aims to have an impact on the performance of the company, then it can be said that it is a strategic human resources management [14].

Cristiani and Peiró (2015) have shown that the SHRM is focused on aligning the organization's strategy with its human resources strategy and on the impact it has on the organizational performance [15]. According to the aforementioned authors, in the theory of strategic human resources management, it is considered that individual performances increase the performance of each department in an organization (supply, stocks, logistics, marketing, production, accounting, finance and others) as they work for them and their department performance [16-18]. Consequently, these will implicitly lead to the increase of the firm's performance as a whole [19]. Therefore, it is appreciated that the individual performance has an impact on the performance of the company through the processes they participate in the departments of which they are part [20].

\section{RESEARCH METHODOLOGY AND RESEARCH ON THE BEST PRACTICES OF THE STRATEGIC HUMAN RESOURCES MANAGEMENT IN THE WESTERN REGION OF ROMANIA}

The investigation sample was made up of large or very large companies (over 250 employees) from the
Western Region of the country, regardless of the nature of the capital (Romanian, foreign, mixed) and regardless of the sector of activity (public or private). We selected only those companies that are independent, with independent decision-making and that are not subsidiaries of a multinational company.

In order to identify the companies with the desired characteristics, we used the database from a specialized site, www.doingbusiness.ro, and subsequently verified on the website of the Ministry of Public Finance Initially, 137 large or very large organizations were identified in the Western Region of Romania. Next, by eliminating local branches of multinational companies, the sample for our research study was reduced to 65 companies, that is more than half.

In order to obtain the information needed, we have used a survey, the research instrument being the questionnaire.

In order to get the most clear and precise answers from the subjects, we use predominantly closed questions, the possible alternatives of answers being unique and predetermined. Respondents were in a position to either choose the correct answer from several predefined variants or to express their perception on certain aspects by using the Likert evaluation scale, which includes five response levels (not at all $=0$, little extent $=1$, average extent $=2$, to a large extent $=3$, total $=4$ ). For the data processing, the program was used in the statistical analysis of data, SPSS (Statistical Package for the Social Sciences).

As the subject of the investigation is a complex one, the identification of the characteristics validating the existence of a strategic management of human resources, as well as of the practices used in this regard, has targeted only the managers of these companies. Therefore, the questionnaire was distributed exclusively to managers.

\section{The type of organization}

Of the total respondents from companies, $50 \%$ belong to companies with Romanian private capital, $26.67 \%$ are employees of companies with foreign private capital, $16.67 \%$ belong to companies with majority state capital and only $6.67 \%$ do part of companies with mixed capital (table 1 and figure 1).

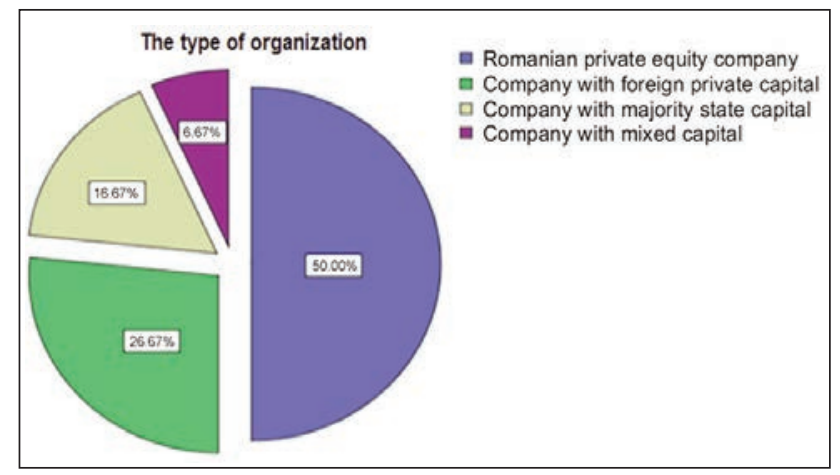

Fig. 1. Distribution of responses regarding the type of organization 
DISTRIBUTION OF RESPONSES REGARDING THE TYPE OF ORGANIZATION IN WHICH THE RESPONDENTS FROM COMPANIES BELONG

\begin{tabular}{|l|c|c|c|c|}
\hline \multicolumn{1}{|c|}{ The type of organization } & Frequency & Percent & Valid percent & Cumulate percent \\
\hline Company with majority state-owned capital & 30 & 50.0 & 50.0 & 50.0 \\
\hline Romanian private equity company & 16 & 26.6666667 & 26.6666667 & 76.6666667 \\
\hline Company with foreign private capital & 10 & 16.6666667 & 16.6666667 & 93.3333334 \\
\hline Company with mixed capital & 4 & 6.66666667 & 6.66666667 & 100.0 \\
\hline Total & 60 & 100.0 & 100.0 & - \\
\hline
\end{tabular}

Table 2

\begin{tabular}{|l|c|c|c|c|}
\hline \multicolumn{5}{|c|}{ DISTRIBUTION OF RESPONSES REGARDING THE MAIN OBJECT OF ACTIVITY } \\
\hline \multicolumn{1}{|c|}{ The main object of activity } & Frequency & Percent & Valid percent & Cumulate percent \\
\hline Another & 18 & 30.0 & 30.0 & 30.0 \\
\hline Production of industrial goods, including textiles & 18 & 30.0 & 30.0 & 60.0 \\
\hline Transport & 10 & 16.6666667 & 16.6666667 & 76.6666667 \\
\hline Services for the population & 9 & 15.0 & 15.0 & 91.6666667 \\
\hline Trade, product distribution & 2 & 3.33333333 & 3.33333333 & 95.0 \\
\hline Services for companies & 2 & 3.33333333 & 3.33333333 & 98.3333334 \\
\hline Construction & 1 & 1.66666667 & 1.66666667 & 100.0 \\
\hline Total & 60 & 100.0 & 100.0 & - \\
\hline
\end{tabular}

\section{The main object of activity}

The respondents were from the most important industries in the western region of Romania, with a focus on production of industrial goods, transportation, services for population and other, representing $91,7 \%$ of the sample (table 2 and figure 2).

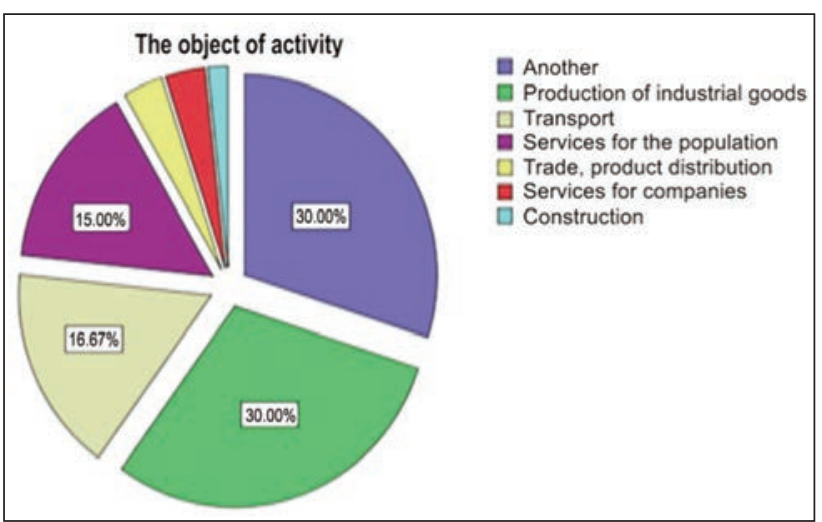

Fig. 2. Distribution of responses regarding the main object of activity

What is the extent to which you believe that the following statements regarding the human resources strategy are in line with the reality of your organization

These 7 statements refer to components of SHRM such as: vision, mission, values, objectives, resources (1); It is materialized in policies, plans, programs, objectives (2); It is derived from the general strategy (3); It is aligned with the general strategy (4);
Supports the realization of the general strategy by initiating human resources activities that are aligned with the companies objectives (5); It aims to create a match between human resources activities so that they support each other (6); It matches human resources practices with the other systems in the organization (7).

Table 3

DISTRIBUTION OF RESPONSES REGARDING THE HUMAN RESOURCES STRATEGY CHARACTERISTICS

\begin{tabular}{|c|c|c|c|c|c|c|c|c|}
\hline \multicolumn{2}{|c|}{ Indicators } & \multirow{2}{*}{$\begin{array}{c}1 \\
60\end{array}$} & \multirow{2}{*}{$\begin{array}{c}2 \\
60\end{array}$} & \multirow{2}{*}{$\begin{array}{l}3 \\
60\end{array}$} & \multirow{2}{*}{$\begin{array}{c}4 \\
60\end{array}$} & \multirow{2}{*}{$\begin{array}{c}5 \\
60\end{array}$} & \multirow{2}{*}{$\begin{array}{c}6 \\
60\end{array}$} & \multirow{2}{*}{$\begin{array}{c}7 \\
60\end{array}$} \\
\hline N & Valid & & & & & & & \\
\hline & Missing & 0 & 0 & 0 & 0 & 0 & 0 & 0 \\
\hline \multicolumn{2}{|c|}{ Median } & 3000 & 2500 & 3000 & 3000 & 3000 & 3000 & 3000 \\
\hline \multicolumn{2}{|c|}{ Module } & 3.0 & 3.0 & 3.0 & 3.0 & 3.0 & 3.0 & 3.0 \\
\hline \multicolumn{2}{|c|}{$\begin{array}{l}\text { General } \\
\text { median }\end{array}$} & \multicolumn{7}{|c|}{3000} \\
\hline \multicolumn{2}{|c|}{$\begin{array}{l}\text { General } \\
\text { module }\end{array}$} & \multicolumn{7}{|c|}{3.0} \\
\hline
\end{tabular}

From the analysis of the data (table 3 ) regarding the distribution of the answers of the respondents from companies, it turns out that most of them have appreciated that there is matching to a large extent of the elements regarding the characteristics of the human resources strategy with the reality of the companies, this being a constant approach among them. 
The calculation of the indicators showing the general tendency of the responses, the median and the module, confirms the previously stated ones, demonstrating that the highest frequency, in the case of all the items, was "to a large extent" response alternative.

The results validate the existence of clearly defined human resources strategies, existing at a formal level, materialized in policies, plans, programs, objectives. These are also vertically integrated with the general business strategy (they derive from this, are aligned with it and support it). Also, it has been proven that human resources strategies aim to create a match between human resources activities, so that they support each other and at the same time match them with the other systems in the researched organizations.

Consequently, we conclude that the analysis of the results of our research validates the existence of a strategic management of human resources (SHRM) in the researched companies.

\section{What is the extent to which the following activities are specific to the Human Resources Department within your organization?}

These statements mainly deal with the administrative, operational aspects of $\mathrm{Hr}$ department, such as (1); Is involved in making all major, strategic decisions (2); It is given an importance comparable to that of the other departments (3); Is an active participant in the development of the company's objectives (4); Is an active participant in the implementation of the company's objectives (5); Formulates/defines the company's vision regarding human resources (6); Communicates the vision regarding human resources across the organization (7); Anticipates the effects of changes in the internal and external environment of the company on the human resources of the company (8); Communicates the human resources specific goals to all those involved in their achievement, the desired results as well as the achieved ones (9); Supports the organization in achieving its organizational goals (10); Is involved in the design of business strategies (11); Is involved in the implementation process of business strategies (12); Elaborates the human resources strategy (13); Initiates actions in which the human resources strategy supports the general business strategy (14); Demonstrates the financial impact of human resources activities (15). From the analysis of the distribution of the answers (see table 4) it appears that in the overwhelming majority of cases the dominant frequency corresponds to the answer variant largely, this being the central tendency. It means that the activities of the Human Resources Department are specific to the analyzed companies to a large measure.

Although the basic activity of the department remains the execution of administrative activities, our research supports the existence of a strategic management of human resources in these companies, the following strengths were identified: participation in the development and implementation of company objectives, formulation and communication of the vision on human resources and of the human resources objectives to all those involved in their achievement, anticipating the effects of changes in the internal and external environment of the company on the human resources of the company, developing the human resources strategy, supporting the organization in achieving the organizational objectives, initiating actions through which the human resources strategy supports the overall strategy. Among the weaknesses identified are: reduced involvement in making strategic business decisions, not giving to the Human Resources Department an importance comparable to that of other departments, its reduced involvement in the design and implementation of business strategies, as well as a low concern for demonstrating the financial impact of human resources activities, these aspects being in contradiction with the appreciation of the department as a strategic partner of the top management.

\section{The extent to which there is a strategic} management of human resources is related to the strategic use of human resources practices (hypothesis 1 - H1)

The premises of establishing hypothesis 1: in the specialized literature we found the idea according to which in order to identify the presence of the strategic human resources management (SHRM), in addition to certain characteristics that must be fulfilled by the human resources strategy, as well as some specific activities of the Human Resources Department,

DISTRIBUTION OF RESPONSES REGARDING THE HUMAN RESOURCES DEPARTMENT ACTIVITIES

\begin{tabular}{|c|c|c|c|c|c|c|c|c|c|c|c|c|c|c|c|c|}
\hline \multicolumn{2}{|c|}{ Indicators } & 1 & 2 & 3 & 4 & 5 & 6 & 7 & 8 & 9 & 10 & 11 & 12 & 13 & 14 & 15 \\
\hline \multirow[t]{2}{*}{$N$} & Valid & 60 & 60 & 60 & 60 & 60 & 60 & 60 & 60 & 60 & 60 & 60 & 60 & 60 & 60 & 60 \\
\hline & Missing & 0 & 0 & 0 & 0 & 0 & 0 & 0 & 0 & 0 & 0 & 0 & 0 & 0 & 0 & 0 \\
\hline \multicolumn{2}{|c|}{ Median } & 4.00 & 2.00 & 3.00 & 3.00 & 2.00 & 3.00 & 3.00 & 2.00 & 3.00 & 3.00 & 2.00 & 2.00 & 3.00 & 3.00 & 2.00 \\
\hline \multicolumn{2}{|c|}{ Module } & 4.0 & 2.0 & $2.0^{a}$ & 3.0 & 3.0 & 3.0 & 3.0 & 3.0 & 3.0 & 3.0 & 2.0 & 2.0 & 3.0 & 3.0 & $2.0^{a}$ \\
\hline \multicolumn{2}{|c|}{ General median } & \multicolumn{15}{|c|}{3000} \\
\hline \multicolumn{2}{|c|}{ General module } & \multicolumn{15}{|c|}{3.0} \\
\hline
\end{tabular}




\begin{tabular}{|c|c|c|c|c|c|c|}
\hline \multicolumn{7}{|c|}{ SOMERS'D TEST - VERIFICATION OF HYPOTHESIS H1 } \\
\hline \multicolumn{3}{|r|}{ Indicators } & Value & $\begin{array}{l}\text { Asymptotic } \\
\text { Standardized }\end{array}$ & $\begin{array}{l}\text { Approximate } \\
\text { (b }\end{array}$ & Approximate \\
\hline \multirow{3}{*}{$\begin{array}{l}\text { Ordinal by } \\
\text { ordinal }\end{array}$} & \multirow[t]{3}{*}{ Somers' d } & Symmetric & 0.476 & 0.067 & 6.455 & 0.000 \\
\hline & & 1. SHRM Dependent & 0.456 & 0.070 & 6.455 & 0.000 \\
\hline & & 2. SHRM practices Dependent & 0.498 & 0.071 & 6.455 & 0.000 \\
\hline
\end{tabular}

there must also be a strategic use of human resources practices, which must be adopted for the long term, in order to contribute to achieving the strategic objectives of the organization.

The results of applying the Somers' d test showed that there is a medium-level association (0.476), directly and statistically significant (Sig. $=0.000$ ) (table 5 and figure 3 ) between the measure of the existence of the strategic management of human resources and that of the human resources practices approached in a strategic way. So, the hypothesis 1 is validated, the extent to which there is a strategic human resources management is related to the human resources practices that support the achievement of the organizational objectives, which influence them directly.

The support provided by the human resources strategy in the realization of the general strategy, implies the initiation of human resources activities that are aligned with the strategic objectives of the company

(hypothesis 2 - H2)

The premises of establishing hypothesis 2: this hypothesis was born out of the desire to verify whether the human resources strategy even supports the realization of the general strategy, by initiating human resources activities, or this aspect exists only at the declarative level. It is compulsory for the human resources strategy to support the overall business strategy.

The application of the Somers' test led to a high value of 0.641 and a value of significance of 0.000 (table 6), which shows that there is a strong association between the variables under test and which is statistically significant (figure 4). Consequently, hypothesis 2 is validated, meaning that the support for the general strategy provided by the human resources strategy

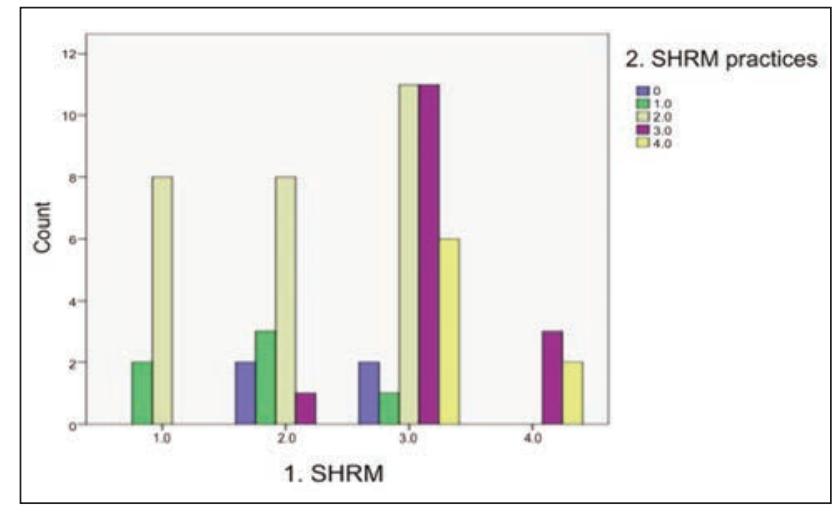

Fig. 3. Concordance between the variables of hypothesis $\mathrm{H} 1$

has involved carrying out human resources activities that go in the same direction, are aligned with it and are approached strategically, i.e. in the long term, precisely for this purpose, that of to contribute to the achievement of the general strategy and, implicitly, of the strategic objectives.

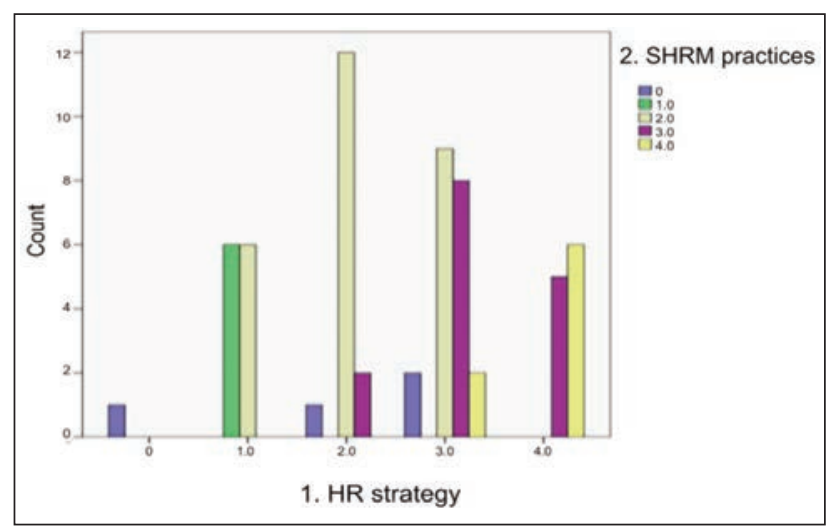

Fig. 4. The concordance between the variables of hypothesis $\mathrm{H} 2$

\begin{tabular}{|c|c|c|c|c|c|c|}
\hline \multicolumn{7}{|c|}{ SOMERS'D TEST - VERIFICATION OF HYPOTHESIS H2 } \\
\hline \multicolumn{3}{|c|}{ Indicators } & \multirow{2}{*}{$\begin{array}{l}\text { Value } \\
0.641 \\
\end{array}$} & \multirow{2}{*}{$\begin{array}{c}\begin{array}{c}\text { Asymptotic } \\
\text { Standardized } \\
\text { Error }^{\mathrm{a}}\end{array} \\
0.069 \\
\end{array}$} & \multirow{2}{*}{$\begin{array}{c}\begin{array}{c}\text { Approximate } \\
\mathrm{T}^{\mathrm{b}}\end{array} \\
8.159 \\
\end{array}$} & \multirow{2}{*}{$\begin{array}{c}\text { Approximate } \\
\text { Significance }\end{array}$} \\
\hline Ordinal by & Somers'd & Symmetric & & & & \\
\hline ordinal & & 1. HR strategy Dependent & 0.658 & 0.075 & 8.159 & 0.000 \\
\hline & & 2. SHRM practices Dependent & 0.624 & 0.068 & 8.159 & 0.000 \\
\hline
\end{tabular}




\section{CONCLUSIONS}

In the given circumstances, human resources have earned a well-deserved position in the top of the importance of the resources available to any company. Their role has become decisive, being the only ones that can ensure the development of an organization or, on the contrary, lead it to the opposite pole, its bankruptcy.

The most striking change in the role of human resources departments is the increasing importance they play in developing and implementing the overall business strategy of the organization, designing and implementing the human resource strategy, and implicitly in making organizational changes and gaining the competitive advantage.

The role of strategic partners granted to the human resources of an organization is essential in this period in which the competitors can quickly copy any strategy of the rivals and the competitive advantage should only be regarded as temporary. Human resources are the only ones that can gain this competitive advantage but also maintain it, being an inexhaustible source of solutions and new ideas.

The performances of textile companies will have direct and propagated effects in other industries and it is going to strengthen the export capacity of a region or country, with strong impact on jobs creation, increasing of living standards and meeting economic and social needs of a community.

Our research indicates that a real transformation can be observed also at the level of the Human Resources Department, whose main tasks, until recently, had a predominantly administrative character (kept records, files, drafted documents, administered the employees of an organization, etc.). Performing these activities is necessary, however in no case are they sufficient for an organization that wants to be successful and achieve outstanding business performance. The human resources function, with all that it implies should be developed to fulfill a strategic partner role within any organization, regardless of its size or object of activity.

The development of the strategic human resources management, the increase of its role within the organization through a more rigorous implementation and a strategic approach become increasingly important concerns for the Romanian managers. In the face of the new realities in the global, national and regional environment, we conclude that there is a strong trend to shift to another, higher level that is the strategic management of human resources (SHRM).

This research can be considered a topical one, the central theme being a subject that has been approached for many years in the international specialized literature. However, we have found a small number of scientific papers, articles, studies in the field in the Romanian academic literature.

The degree of scientific novelty of the present work resides both in the way of presentation and the nature of the information contained in the theoretical part of the paper, as well as in the reality caught in the applicative part, through the realization of a well planned and executed field investigation, representative for the organizations in the Western Region of the country, in order to identify the aspects described in the first part of the paper.

\section{ACKNOWLEDGEMENTS}

This research was supported financially by the project CNFIS-FDI-2018-0582 - Supporting Excellence Research within The Bucharest University of Economic Studies in the context of the principles of sustainable development and open research 6 . Supporting field research excellence in universities Beneficiary: The Bucharest University of Economic Studies.

\section{REFERENCES}

[1] Clark, H., Using Language, Cambridge University Press, United Kingdom, 1996

[2] Costache, G., Marinas, C.V., Igret, R., Burlacu, S., Internship in the HR department-organizational and individual perspectives, In: Proceedings of the International Management Conference, 2015, 9, 1, 359-370

[3] Popescu, I.D., The correspondence between workforce skills and company needs, In: Industria Textila, 2013, 64, 3, $168-175$

[4] Burlacu, S., Evaluation of training process by fuzzy techniques, In: Administratie si Management Public, 2010, 15, 162

[5] Burlacu, S, Role of training in the knowledge society, In: Proceedings of Administration and Public Management International Conference, 2010, 6, 1, 203-208

[6] Burlacu, S., Integrating the e-learning dimension in the Edu-Res master's programme, In: Proceedings of Administration and Public Management International Conference, 2014, 10, 1, 139-147

[7] Walker, J., Human resource planning, McGraw-Hill, New York, 1980

[8] Devanna, M., Fombrun, C., Tichy, N., Human resources management: A strategic perspective, In: Organizational Dynamics, 1981, 9, 3, 51-67

[9] Miles, R., Snow, C., Designing strategic human resource systems, In: Organizational Dynamics, 1984,13, 36-52

[10] Fombrun, C., Tichy, N., Devanna, M., Strategic human resource management, John Wiley \& Sons, New York, 1984

[11] Armstrong, M., A Handbook of Human Resource Management Practice, Kogan Page Publishers, London, United Kingdom, 2006

[12] Lefter, V., Marincas, C., Puia, R., Strategic human resource management, In: Review of Management and Economical Engineering, 2007, 6, 5, 349-353 
[13] Uysal, G., Mayis, O., Stages, Content, and Theory of Strategic Human Resource Management (SHRM): An Exploratory Study, In: Journal of Modern Accounting and Auditing, February 2014, 10, 2, 252-256

[14] Jianu, I., Dobre, I., Bodislav, D. A., Radulescu, C.V., Burlacu, S., The implications of institutional specificities on the income inequalities drivers in European Union, In: Economic Computation and Economic Cybernetics Studies and Research, 2019, 53, 2, 59-76

[15] Cristiani, A., Peiró, J., Human resource function strategic role and trade unions: exploring their impact on human resource management practices in Uruguayan firms, In: The International Journal of Human Resource Management, 2015, 26, 3, 381-400

[16] Gîrneaţă, A., Giurgiu, A., Dobrin, O. C., Popa, I., Popescu, D. I., Cuc, S., Voicu, L., Performance management practices in Romanian textile and clothing companies, In: Industria Textila, 2015, 66, 2, 108-113

[17] Doing business platform: $h$ ttp://doingbusiness.ro/financiar/?financiar=financiar

[18] Ministry of Finance website: http://www.mfinante.ro/agenticod.html?pagina=domenii

[19] Dima, C., Badea, L., Cristescu, A., Consumer perception concerning the trade of counterfeit clothing brands in Romania. A pilot study - Southern region and Bucharest, In: Industria Textila, 2017, 68, 5, 380-387, https://doi.org/ 10.35530/IT.068.05.1366

[20] Bratucu, G., Epuran, G., Gârdan, D.A., Bumbas, F., Zamfirache, A., Gârdan, I.P., The evolution of textile and clothing industry in Romania: an analysis from the perspective of imports and exports determinants, In: Industria Textila, 2017, 68, 2, 147-155, https://doi.org/ IT.068.02.1236

\section{Authors:}

\section{MARIAN NASTASE1 ${ }^{1}$ NICOLAE BIBU², ANCA-IOANA MUNTEANU³, ILEANA MIRCIOI (VALIMAREANU) ${ }^{1}$, MARGARETA STELA FLORESCU ${ }^{1}$}

${ }^{1}$ Bucharest University of Economic Studies, Faculty of Management, Management, Piata Romana, No. 6, 010374, Bucharest, Romania e-mail: nastasem1@yahoo.com, ileanamircioi@gmail.com, margareta.florescu@ari.ase.ro

${ }^{2}$ West University of Timisoara, Faculty of Economics and Business Administration, Management,

J. H. Pestalozzi Street, No. 16, 300115, Timisoara, Romania e-mail: nicolae.bibu@e-uvt.ro

${ }^{3}$ West University of Timisoara, Faculty of Economics and Business Administration, East European Center for Research in Economics and Business (ECREB), J. H. Pestalozzi Street, No. 16, 300115, Timisoara, Romania, e-mail: ioana.munteanu@e-uvt.ro

\section{Corresponding author:}

MARIAN NASTASE

e-mail: nastasem1@yahoo.com 


\title{
Assessment of the research field in the European universities and analysis of the research projects impact on academic performance
}

\author{
DOI: 10.35530/IT.070.06.1753
}

\author{
MARGARETA STELA FLORESCU \\ ADRIANA ANA MARIA DAVIDESCU \\ ANCA-IOANA MOSORA
}

CRISTINA ALPOPI

MARIAN NASTASE

\section{ABSTRACT - REZUMAT}

\section{Assessment of the research field in the European universities and analysis of the research projects impact on academic performance}

\begin{abstract}
The research concept refers to the search for information; it can be defined as a scientific and systematic search for relevant information on a particular topic. In fact, research is an art of scientific investigation. Some consider research to be a movement, a movement from knowledge to ignorance. In this sense, the article allows to carry out an evaluation of the field of research within the universities of Europe regarding the research process in the university environment and the impact of the research projects on the academic performances. Bucharest University of Economic Studies have been involved in different scientific research projects in order to foster the modernization of the textile field, to create a favourable environment for the textile companies where they can develop their activities, implicitly supporting a sustainable development of this industry. One of the strategic directions for such development was to design and support the development of clusters for competitiveness in this field. Through this paper, we have conducted an in-depth analysis of the impact of research projects in the Bucharest University of Economic Studies in the period 2014-2018, using the propensity score method and performing a descriptive analysis of the data. One of the main results obtained, which is also consistent with the literature, is that research projects in the academic environment have a significant impact on the performance index $h$, the coefficient of the variable $h$ index being statistically positive and significant. Thus, with an increase in the number of teachers benefiting from research projects, index $h$ will also register an increase at the level of each individual. Funding based on academic performance can widen the gap between research and teaching. Therefore, the quality measurement instruments of the research should be treated with greater indulgence, as it is not possible to describe the contributions of an individual in a certain field of research based on simple numerical values.
\end{abstract}

Keywords: academic research, evaluation, best practices, performance, research projects, impact

\section{Analiza activităţii de cercetare în universitățile din Europa și impactul proiectelor de cercetare asupra performanțelor academice}

Conceptul de cercetare se referă la căutarea de informaţii; acesta poate fi definit drept o căutare ştiinţifică şi sistematică de informaţii pertinente cu privire la un anumit subiect. De fapt, cercetarea este o „artă” de investigare ştiinţifică. Unii consideră că cercetarea este o mişcare, o mişcare de la cunoaştere la necunoaştere. În acest sens, articolul iș̦i permite să realizeze o evaluare a domeniului cercetării în cadrul universităţilor din Europa privind procesul de cercetare în mediul universitar și impactul proiectelor de cercetare asupra performanțelor academice. Academia de Studii Economice București a fost implicată în diferite proiecte de cercetare științifică în vederea participării la modernizarea domeniului textil, pentru a crea un mediu favorabil companiilor din acest domeniu în care ele să se poată dezvolta și, implicit, să asigure o evoluție sustenabilă a acestei industrii. Una dintre direcțiile strategice a fost sprijinirea dezvoltării clusterelor pentru competitivitate în acest domeniu. Prin intermediul lucrării am realizat o analiză aprofundată a impactului pe care îl au proiectele de cercetare în cadrul Academiei de Studii Economice în perioada 2014-2018, utilizând metoda scorului de propensiune şi realizând o analiză descriptivă a datelor. Unul dintre principalele rezultate obţinute, care este şi în concordanţă cu literatura de specialitate, este acela că proiectele de cercetare din mediul academic au un impact semnificativ asupra indicelui de performanţă $h$, coeficientul variabilei $h$ index fiind pozitiv şi semnificativ din punct de vedere statistic. Finanţarea bazată pe performanţele academice poate lărgi decalajul dintre cercetare şi predare. Prin urmare, instrumentele de măsurare ale calităţii cercetării ar trebui să fie tratate cu o mai mare indulgenţă, nefiind posibil să se descrie contribuţiile unui individ într-un anumit domeniu de cercetare pe baza unor valori numerice simple.

Cuvinte-cheie: cercetare academică, evaluare, bune practici, performanță, proiecte de cercetare, impact

\section{INTRODUCTION}

Research is an academic activity and as such the term should be used in a technical sense. According to Clifford Woody, research contains defining and redefining problems, formulating hypotheses or suggested solutions; data collection, organization and evaluation; setting the assumptions and conclusions; and at least carefully testing the conclusions to be able to verify whether they fit the hypotheses formulated.

Slesinger and Stephenson, in the Encyclopedia of Social Sciences, defined research as a process of 
manipulating concepts or symbols in order to generalize the expansion, correction, or verification of knowledge, whether it helps to build theory or practice art. Research is therefore an original contribution to the existing stock of knowledge that contributes to its development. This is the pursuit of truth through the study, observation, comparison and experimentation [1].

Evaluation has become a regular practice in science, technology and innovation management programs. This tendency is determined both by the pressure exerted by the company on the responsibility regarding the public expenses, and by the increase of the interest for evaluation as a basis for the planning and management of the programs. There is no clear definition of evaluation, but for the present purposes, it can be defined as a series of analytical approaches designed to identify and interpret the results and/or consequences obtained in order to generate concrete information that can be used for future actions. In order to increase the quality of education, educational research from different fields of study is carried out by well-trained scientists [2]. The teacher, representing one of the most important actors in the international system, expects to practice educational applications in the classroom in the light of the results obtained from the research [3].

In other words, teachers need to closely monitor the evolution of the educational field and monitor contemporary developments through research findings [4-5]. That is why teachers need to be aware of everything new in the field of educational research [6-7] and to fulfill the role of researcher [8].

Teachers, like all people in the field of work, must closely follow the latest developments in the field of activity and then put into practice the experience and knowledge gained in order to improve their professional competence [9-10]. In this sense, there are expectations from the teachers regarding the explanation and application of the results obtained in different studies of their own students. However, it cannot be said that teachers have research benefits [11]. Although it is considered that educational research has increased quantitatively $[2,12]$, the utility rate of these studies remains quite low in terms of educational practices $[4,11,17-18]$. In this context, it can be said that the initiatives of the teachers to share with the students the knowledge acquired in the field of research play a very important role in education $[11,13]$. Therefore, teachers' views on educational research can be considered very important to researchers [2, 14, 16].

In the studies based on the research of the perceptions and attitudes of the teachers related to the field of educational research, the main results reveal that the teachers generally have negative perceptions about the research and that they consider that the results of the research are far from offering solutions to the problems encountered in the educational system [17]. The results of these studies reinforce the idea that teachers have negative opinions and attitudes towards educational research.
Although most studies have been conducted considering quantitative research methodology, there appears to be a study in which qualitative research methodology is pursued to determine teachers' views on educational research. The study by Yilmaz and Kilicoglu (2013) seems to adopt a qualitative research method to identify the views of teachers regarding educational research; this study focuses exclusively on comparing the opinions of teachers and students who have not yet graduated [18].

Therefore, it can be said that more studies are needed in which a qualitative method is applied in order to examine in detail the opinions of teachers regarding research. In this regard, it can be stated that there is a significant difference on this topic in the specialized literature. Even if the use of quantitative methods in determining teachers' attitudes is considered quite important, it is clear that at present there are only studies based on qualitative methods.

Taking into account the aforementioned aspects, the main objective of this paper is to identify the impact that the research projects have on the academic performances at the level of the teachers from the Bucharest University of Economic Studies, using complex statistical methods, based on the selection of a group of students, non-treats similar to treats using the propensity score method (Propensity Score Matching)

\section{CRITICAL ANALYSIS OF THE EVOLUTION OF THE CONCEPT OF THE "ACADEMIC RESEARCH PROCESS" IN THE SPECIALIZED LITERATURE}

The research process is described as a type of research carried out by practitioners in their own context and which has been accepted as a way of promoting professional development. Elliot (2008) describes educational research as a process of mutual learning, with teachers learning from each other as well as from their own students [19]. Beycioglu (2010) conducted a study on a sample of 300 Malatya teachers in order to identify teachers' views on educational research [20]. The obtained results show that $68 \%$ of the teachers are familiar with the educational research from the moment they started teaching. Academic journals were among the most frequent means of accessing research studies $(28.2 \%)$, followed by books (18.8\%). Regarding gender differences, there were no statistically significant differences between men and women.

McNamara (2002) stated that the most negative view of the research teachers was the quantitative and statistical nature of the research [21]. They cannot be based on statistics, being open for manipulation. Also, teachers believe that academics produce "dry things" that have no applicability in practice.

Shkedi (1998) stated that teachers become familiar with the field of research through the requirements of the academic environment [22]. Despite the problems encountered, the teachers were not motivated to develop in this area and those who were, seemed to do it at random and not on a regular basis. 
However, research has been carried out in the field of English, with the purpose of identifying the research perceptions of the teachers. McDonough (1990) conducted a study on a sample of 34 English teachers aimed at finding out their vision for the field of research [23]. Similar to what Brown et al. (1992), the results of the study reflect that the teachers were not involved in the roles [24]. Allison Carey et al. (2007) analyzed perceptions of the relationship between professional development and research on a sample of 22 foreign language teachers from Canada, reporting certain factors that prevent teachers from developing in the field of research [25]. These factors include the lack of time, courage, expertise and confusion over the concept of "real research". McNamara (2002) obtained similar results by the fact that the workload of the teachers prevents the increase of the productivity in the research field [21].

Many researchers have emphasized the conflicting nature of teachers' demands, trying to meet the needs of the professional field on the one hand, and on the other, to comply with the academic performance rules for which the number of publications is of major importance. Education is located near the lower limit in the hierarchy of disciplines within the university, which means that it is particularly vulnerable to accusations that the academic performance rules are not respected.

The number of publications is sometimes interpreted as an indicator of quality, sometimes as an indicator of productivity. The logical understanding of each interpretation is subtle, as well as the fact that the same indicator is used for both productivity and quality measurement. Apparently, it could be said that a simple quantitative index could highlight to a greater extent productivity and not quality. In fact, according to the literature, the productivity of research in the academic environment is directly proportional to the number of publications. This way of defining research productivity ignores the fact that the term productivity implies a relationship between inputs and outputs. This definition, rather, equates productivity with product.

Over time, there have been numerous criticisms regarding the emphasis placed on the number of publications in order to recognize academic performance. These criticisms determine the faculty to focus on research and publication to the detriment of other activities, especially in pre-university education. W.S. Massy and R. Zemsky (1994) consider this as a "weakening" of the institution's responsibilities [26]. Shelly Park (1996) stated that men spend more time on research studies than women, who devote more time to teaching. This statement suggests the idea that men publish more in comparison with women. Based on the idea that research is the most rewarding activity within a university and also in most studies it is suggested that research articles are evaluated on the basis of quantity rather than quality, Park says that men receive higher rewards than women [27].
Robert T. Blackburn and Janet H. Lawrence (1995) challenge the claim that men are more public than women [28]. The two reports that while the results of more than 50 studies show that women publish less; the latest studies show that there is gender equality in terms of number of publications.

Examining the links between funding and citation from other studies is a window to research and understand the sponsorship processes, performance and results obtained in the world of scientific research.

The evaluation of the research projects is used to decide on the funding based on the academic performance of the researchers, projects, departments and institutions [29]. The assumption is that the funds allocated after the performance evaluation will have a higher yield. Over time there have been many debates about the benefits of evaluation as a tool for political research.

Evaluation, in a certain form, inevitably occurs whenever a paper is submitted for publication, the appointment of a new teacher or the promotion of a teacher or when a grant is offered to a school or government body. However, although there are many studies in the literature on performance indicators, there is little consensus as to which measures work best [30]. At the same time, the objectives of the evaluation tend to be defined by the agency responsible for verifying the work.

\section{RESEARCH METHODOLOGY ON BEST PRACTICES IN EUROPEAN UNIVERSITIES. THE IMPACT OF RESEARCH PROJECTS ON ACADEMIC PERFORMANCE}

The investigation sample was made up of large universities from some countries regarding the evaluation of the research field. In the UK, research at universities is funded through a dual system that combines the funding of general institutions with grants and contracts. At the end of the 1980, the system underwent radical changes, wishing that universities, polytechnics and colleges would be transformed into public institutions, to be carried out at the expense of the state, to suppliers, to serve customers.

In the last decade, the United Kingdom has developed one of the most advanced research evaluation systems in Europe [31]. According to the new system, performance evaluation is performed not only at the level of researcher and individual project, but also at the institutional and national level. The first application evaluation exercise (EVC) was conducted in 1986, and was repeated in 1989, 1992, 1996 and 2001

In the Netherlands, research in the academic environment is also funded through a dual system. The Dutch Ministry of Education and Science offers funding through the so-called "first stream" program. Grants for "secondary flows" come from research councils and foundations, and contracts for "third flows" come from government departments as well as 
from other organizations. As in other parts, concern about quality and usefulness has led to the provision of responsibility measures. In 1979, changes in research management were recommended, and in 1983 a "conditional funding" system was introduced in order to make research more socially efficient [32]. Through this scheme, a distinction was made between the funds granted for teaching and those for research. Thus, the research posts were funded according to the quality of the publication (Steen and Eijffinger). In the Netherlands, research in the academic environment is classified according to disciplines and programs.

The Dutch used the assessments to develop strategies and not to allocate funds. On the one hand, as Arie Rip and Barend vad der Meulen have shown, Dutch culture prefers informal "bottom-up" evaluations. On the other hand, policy makers are more interested in making strategic choices than in evaluating performance [33]. Therefore, each of the 27 disciplines is evaluated by a different committee. In contrast to British practice, according to which all disciplines are evaluated simultaneously, in Dutch culture the assessments are made over four to six years.

In Germany, most academic research is carried out either in research institutes (such as Max Plank or Fraunhofer) or in "scientific universities". Some research also takes place within polytechnics, which are mainly educational institutions. In German culture, research is funded through contracts with government agencies, with only a few private universities. There are three categories of public funding for research in German culture. The first category refers to the institutional financing, which takes the form of subsidies blocked from the state. Institutional financing is applied in almost two thirds of the total university expenses and covers the basic infrastructure and staff. The second category is in the form of a capital grant for buildings and equipment, being provided by the federal government. The third source is "third party funds" which are grants and contracts awarded by public institutions for specific projects. As in the case of other countries, these funds are awarded based on reviews, using criteria of scientific excellence and social utility. In order to realize the research budgets, a coefficient of research and development is derived from surveys that show the time spent for research and teaching. In general, academic performance was not considered for the allocation of funds and there were no evaluations for this purpose [34]. However, in recent years, several countries have allocated additional resources for performance.

The Nordic countries use a dual system to finance research in the academic environment. In Denmark and Finland, research councils grant grants based on international review, and the government grants institutional funding. Only in Denmark and Finland funds are granted for academic performance. In Denmark, in 1994 a new budgeting system was introduced through which a distinction is made between the funds granted for teaching and those granted for research.
The budget contains 5 elements: a basic financing, a financing according to the performance in teaching, a financing for research, a financing for other activities and a capital grant. Until 1995, research funds were allocated in ascending order. Since then, the amounts granted have begun to depend on the volume of publications and revenues from external research. No other performance measurement indicator is used, although the number of PhD students helps determine the performance for teaching.

In Norway, universities benefit from blocked funds and there is no difference between teaching and research. Until recently, there was no attempt to use a performance measurement identifier, except for the amount of each graduate student. Similarly, there is no funding for academic performance in Sweden. Following the 1993 legislation, the results of the examinations represent the only indicator taken into account in the decision to allocate funds.

Of the Nordic countries, Finland has the most experience in performance-based financing [35] which makes us think that it is a developed country. Most of the academic research in Finland is carried out within the Finnish universities, being financed by funds allocated by the Ministry of Education. The didactic component is represented by the number of graduates of the masters programs, and the research element by the number of graduates of the doctoral studies. The financing of the projects is allocated to the programs that the government defines. Research funding is granted on the basis of quality and impact indicators, being used to create centers of excellence, to increase international collaboration, to improve the placement of graduates and to meet the planned objectives.

After 1945, the national research systems in Eastern Europe were based on the Soviet tripartite model, according to which the universities must focus on teaching, the research being done in the institutes of the Academy, and the research applied either in academic institutions or in government ministries [36]. In the last 10 years, with the development of open market economies, the system has undergone some changes. Research evaluation has emerged as a tool for examining how budgets could be reduced without the need for research, with mutual evaluation becoming the main tool used [37]. While national systems have undergone major changes, academies continue to play an important role in the field of research, and evaluations have focused on institutes.

The Polish universities compete for funds based on the number of registered students and through two hypotheses submitted by the Scientific Research Committee. The first hypothesis represents a system of individual and team financing based on open competition and mutual evaluation. The second hypothesis, called "statutory funding", is allocated to faculties within universities based on past assessments. Each year, the institutions must present the achievements recorded during the past year and also a research plan for the coming year. The evaluations are carried 
out by groups of experts who assign the institutions to a certain category.

In 2000 , New Zealand began to allocate $20 \%$ of the institutional funding based on mutual assessments. If the experiment proves to be successful, it is intended to increase from $20 \%$ to $80 \%$. In Australia and Hong Kong, there are national research assessments, and both cultures use the results obtained for funding.

In many studies on the impact of funding on research activity, the implicit or explicit theoretical assumption is that reliance on external resources forces research organizations and implicitly researchers to change their field of activity to benefit from changes in funding [38]. There is no simple mechanism for funding the research field, but rather it is a complex combination of the different allocation mechanisms, the sources of funding and the criteria on which the funds are granted [39]. Sometimes these incentives balance each other out, and sometimes they reinforce each other [40-41].

There is no doubt that the research activity is affected by several other contextual elements, from cultural practices to the political legitimacy of a system. For example, research assessments and global scientific policy - as long as they are not directly related to funding - can have institutional consequences [42]. On the other hand, researchers and universities are able to adapt their behavior and organization to new external requirements so that their field of activity is not affected if the requirements do not suit their own interests [43]. In addition, foreign policy pressures and incentives are mediated by existing disciplinary cultures [44].

Assessing the potential impact of research projects on academic performance within the Bucharest University of Economic Studies (ASE) makes it possible to conduct more expansive investigations on research funding in an advanced research university and the relationships between funding and other features of a published work, including citation, this being the major unit of impact measurement The evaluation of the research projects is used to decide on the funding based on the academic performance of the researchers, projects, departments and institutions.

Bucharest University of Economic Studies have been involved in different scientific research projects in order to foster the modernization of the textile field, to create a favourable environment for the textile companies where they can develop their activities, implicitly supporting a sustainable development of this industry. One of the strategic directions for such development was to design and support the development of clusters for competitiveness in this field.

In the analysis from the case study presented in this paper, it was investigated the provisions and results of different projects with the textile industry. Ones of the main scientific research projects in this field were "Entrepreneurial culture - a chance to develop the entrepreneurial spirit of the employees in the textile industry" and "Postdoctoral school Economics of knowledge transfer in sustainable development and environmental protection".

We can see from these examples that different research entities share a continuous preoccupation for fostering the research and development activities in order to have access to the latest know-how in the textile field. At the same time, the joint projects are designed to bring higher value to the textile industry by taking into consideration a better economic perspective and a strong connection to the market demand.

In order to achieve this, the propensity score matching (PSM) method was used, which aimed to quantify the effect of participating in research projects both as a member and as a director on the academic performances of ASE teachers, performances evaluated by four result indicators: number of ISI articles, number of BDI articles, $h$ index and i10 index for the period 2014-2018.

The concept of Propensity Score Matching (PSM) was first introduced by Rosenbaum and Rubin (1983) in the paper entitled "The Central Role of the Propensity Score in Observational Studies for Casual Effects". Heckman (1997) also played an important role in developing the propensity score method. It focused on the selection tendency, with a primary focus on certain random deductions when there is an uneven distribution. Heckman later developed the difference approach based on the application of PSM. A propensity score $(\pi)$ for an individual $(s)$ is defined by Rosenbaum and Rubin (1993) as the conditional probability $(P)$ that it be distributed in the treatment group or in the control group $(T)$, given a vector of covariate observations $\left(X_{i}\right)$, expressed as [45]:

$$
\pi_{i}=P\left(T_{i}=1 \mid X_{i}\right)
$$

Since the propensity score is a probability, its values can be between 0 and 1 . If the propensity score was used in a randomized trial comparing two groups, then the propensity score for each individual in the study would be 0.50 . This result is due to the fact that each participant would be randomly assigned to either the treatment group or the control group with a probability of $50 \%$. In study models where there is no randomization, such as in a quasi-experimental project, the propensity score should be estimated. Propensity score values depend on a vector of covariate observations that are associated with receiving treatment. In general, if a treated subject and a subject in the control group have the same propensity score, it means that the observations are controlled. Therefore, any difference between the treatment group and the control group will be taken into account and will not be the result of the observed covariates.

The main limitation of a study is given by the fact that there may be random selections of the subjects, but it is not possible to randomly assign them to a certain group (treatment or control). When we are faced with the lack of randomization, no deductions can be made because it is not possible to determine whether the difference in results between the treated group 
and the untreated group (the control group) is due to the treatment or the differences between the subjects regarding other characteristics. Individuals with certain characteristics may be assigned to the treatment group with a higher probability than those without those characteristics.

Generally, propensity scores are calculated by logistic regression or by classification and regression tree analysis.

1. Logistic regression: is the most commonly used method for estimating propensity scores. It is a model used to determine the likelihood of an event occurring.

$$
\ln \frac{e\left(x_{i}\right)}{1-e\left(x_{i}\right)}=\ln \frac{\operatorname{Pr}\left(z_{i}=1 \mid x_{i}\right)}{1-\operatorname{Pr}\left(z_{i}=1 \mid x_{i}\right)}=\alpha+\beta^{T} x_{i}
$$

where:

$$
\begin{aligned}
& e\left(x_{i}\right)=\operatorname{Pr}\left(z_{i}=1 \mid x_{i}\right) \\
& e\left(X_{i}\right)=b_{0}+b_{1} X_{1}+b_{2} X_{2}+b_{3} X_{3}+\ldots+b_{i} X_{i}
\end{aligned}
$$

and:

$b_{0}$ - free term;

$b_{i}$ - regression coefficient;

$x_{i}$ - treatment variables;

$x_{i}$ - the observed values of the variables.

In the case of logistic regression, the dependent variable is a dummy variable, $Z i=1$ being the value assigned to the individuals in the treatment group, and $Z i=0$, representing the value of those belonging to the control group.

2. The classification and regression tree model $(C A R T)$ : this is a non-parametric method that can effectively divide individuals into homogeneous subgroups. It is not used as much as the logistic regression for estimating propensity scores because it is much more complex.

Adjusting the estimated propensity scores is performed using one or a combination of the four main methods: stratification, matching, regression and weighting.

\section{The empirical results}

Analyzing the table 1 it can be noticed that at the level of the group of treaties, there are, on average, 4.55 scientific articles present in the journals listed in the bibliographic database of the Institute of Scientific Information (ISI). The average of the specialized arti- cles existing in the international databases at the level of the studied group is 5.03 . Also, it can be concluded on the basis of the obtained results that, on average, about 5 papers published by the university staff that make up the group of treaties were cited at least 5 times, the index $h$ having a value equal to 5.11. The average value of the $\mathrm{i} 10$ index suggests that approximately 3 scientific articles recorded at least 10 citations. It is also worth noting that for both the scientific articles present in the journals listed in the Institute of Science (Web of Science) bibliographic database and for the existing publications in international databases (BDI) the value of the median is 4 , which means that $50 \%$ of those included in the treaty group have published more than 4 specialized articles $\mathrm{BDI}$, and $50 \%$ have published less than 4 papers, respectively $50 \%$ of the university staff register more than 4 articles listed WoS (ISI), and 50\% have less than 4 WoS listed items.

Based on the modal value of the performance index $\mathrm{h}$, it can be concluded that the most frequent value of the index $\mathrm{h}$ is 4 , which means that in the studied group, most have 4 specialized papers that have been cited at least 4 times. The highest value of the $\mathrm{h}$ index is 15, and the smallest is 1 . It should also be noted that the maximum number of BDI articles is lower than that of WoS articles. The index h, considered in the specialty literature as an indicator of measuring the performance in the field of research has a maximum value of 15 , this being registered by a single teacher. Most researchers (31) obtained a value of index $\mathrm{h}$ equal to 4 , a result identified previously, in the descriptive analysis of the data. The most frequent value recorded for the index $\mathrm{i} 10$ in the studied group is 23 , this threshold being reached by a single teacher. The value 23 of the i10 index suggests the idea that 23 scientific articles have been cited at least 10 times. 30 university staff does not register values for the 10 index, and 41 of them have a single article with at least 10 citations. Most of the specialized articles existing in international databases belong to the university staff with the position of doctor university professor, and the few (67) belong to the university assistants. An explanation for these results of the distribution of the number of BDI articles according to the didactic degree would be that, a professor is based on several years of experience in the field of

Table 1

\begin{tabular}{|l|l|c|c|c|c|}
\hline \multicolumn{5}{|c|}{ DESCRIPTIVE ANALYSIS OF TREATMENT GROUP DATA DURING THE PERIOD 2014-2018 } \\
\hline \multicolumn{2}{|l|}{} & i10_index & no_art_ISI_sum & no_art_BDI_sum & h_index \\
\hline $\mathrm{N}$ & Valid & 152 & 142 & 167 & 152 \\
\hline Mean & Missing & 37 & 47 & 22 & 37 \\
\hline Median & 3.07 & 4.55 & 5.03 & 5.11 \\
\hline Mode & 2.00 & 4.00 & 4.00 & 5.00 \\
\hline Minimum & 1 & 1 & 1 & 1 \\
\hline Maximum & 0 & 1 & 1 & 1 \\
\hline
\end{tabular}


DESCRIPTIVE ANALYSIS OF THE DATA OF THE CONTROL GROUP DURING THE PERIOD 2014-2018

\begin{tabular}{|l|l|c|c|c|c|}
\hline \multicolumn{2}{|l|}{} & no_art_ISI_sum & no_art_BDI_sum & h_index & i10_index \\
\hline $\mathrm{N}$ & Valid & 673 & 598 & 466 & 466 \\
\hline & Missing & 321 & 396 & 528 & 528 \\
\hline Mean & 2.47 & 3.69 & 4.66 & 2.96 \\
\hline Median & 1.00 & 2.00 & 4.00 & 1.00 \\
\hline Mode & 1 & 1 & 3 & 0 \\
\hline Minimum & 1 & 1 & 0 & 0 \\
\hline Maximum & 59 & 75 & 27 & 92 \\
\hline
\end{tabular}

research and has a greater recognition both nationally and internationally than an assistant at the beginning of his career. It also has more resources and funds needed to publish the works. According to the literature, individuals who are senior in the field of research enjoy greater recognition and receive easier funding from organizations.

As expected after analyzing the results obtained based on the BDI and WoS articles, the average value of the average $\mathrm{h}$ index among doctoral university teachers is 6.12 , being the highest value recorded at the didactic level. It is worth noting that the average $\mathrm{h}$ index for the teaching degree of doctoral assistant is higher than that of the university lecturers. This result could be explained by the fact that the assistants enjoy the fact that they appear as coauthors on certain papers published by the university professors. The value of the average $h$ index suggests that, on average, an individual with the degree of doctoral university professor published 6 scientific articles that were subsequently cited at least 6 times. In the case of the average i10 index, the registered value is 4.2 , which means that, on average, each university professor included in the group of treaties has 4 specialized publications that have registered a number of citations at least equal to 10 .

It can be observed that at the control group level, there are, on average, 2.47 scientific articles present in the journals listed in the bibliographic database of the Institute of Scientific Information. The average value of the $i 10$ index leads to the conclusion that approximately 3 scientific articles registered at least 10 citations. Based on the obtained results, it can be stated that, on average, about 4 works published by the members of the control group registered at least 4 citations, the index $\mathrm{h}$ being equal to 4.66 .

It is also worth noting that for both the WoS articles and the i10 index, the median value is equal to 1 , which means that $50 \%$ of the individuals included in the control group have more than 1 paper present in the journals listed on the basis WoS bibliographic data, and $50 \%$ have less than one WoS-rated specialty article. For scientific articles existing in international databases, the median is equal to 2 , and the median for the performance index $h$ equals 4 , indicates that $50 \%$ of the control group has more than
4 published articles that have registered at least 4 citations and $50 \%$ have less than 4 articles published with the same number of citations.

Analyzing the modal value of the performance index $\mathrm{h}$, it can be concluded that most frequent value is 3 , which means that at the control group level; most individuals have published 3 specialized articles that have been cited at least 3 times. The highest value of index $\mathrm{h}$ is 27 , and the smallest is 0 . According to the literature, an index $\mathrm{h}$ equal to 0 does not necessarily indicate that a researcher was completely inactive: the author has already published a series of papers, but if none was mentioned at least once, the index $h$ is 0 . Unlike the results obtained for the group of treaties, the maximum number of BDI articles is higher than that of ISI articles. In table 2, the main results obtained from estimating the propensity score (PSM) method can be identified. A first notable result that is in line with the specialized literature is that the research projects carried out within the Bucharest University of Economic Studies during the period 2014-2018 have a significant impact on the performance index $\mathrm{h}$, which means that an increase in the number of research projects by $1 \%$, the value of index $\mathrm{h}$ for a teacher from the Bucharest University of Economic Studies will increase by $0.78 \%$.

Another important result is that the i10 index is also influenced by the research projects, being statistically significant and positive. This result suggests that, as in the case of index $h$, an increase in the number of research articles will result in a higher value of index i10 for an ASE teacher and more than this, the number of publications with at least 10 registered citations will increase with the number of research articles.

\section{CONCLUSIONS}

In the given circumstances, the Performance Based Assessment System, as it encourages competition, may also encourage the shift towards "homogenizing" research, discouraging experiments with new approaches and rewarding "safe" research regardless of their benefits to society. The decrease in diversity can be harmful. Moreover, a system for which publications are a key criterion encourages "inflation of publications". Certainly, many academics will 
respond by participating in the "game" without necessarily improving their performance (D. Cannadine, 1999, pp. 18-19).

In Romania, the performance of teachers in the field of research is weak compared to other countries in Europe. According to the specialized literature, Romania is ranked in the last places at European level regarding the scientific publications existing in journals listed in the bibliographic database of the Institute of Scientific Information. Also, Romania has low values compared to other countries in terms of the value of the $h$ performance index, which in countries such as the United States of America, Great Britain and Germany is equal to 400 , respectively 200 and 206.

Through this paper, we have conducted an in-depth analysis of the impact of research projects in the Bucharest University of Economic Studies in the period 2014-2018, using the propensity score method and performing a descriptive analysis of the data. One of the main results obtained, which is also consistent with the literature, is that research projects in the academic environment have a significant impact on the performance index $h$, the coefficient of the variable $h$ index being statistically positive and significant. Thus, with an increase in the number of teachers benefiting from research projects, index $h$ will also register an increase at the level of each individual.
The research projects carried out within the Bucharest University of Economic Studies in the period 2014-2018 also had a significant impact on the $\mathrm{i} 10$ index. This result suggests that an increase in the number of research articles will result in a higher i10 index value for an ASE teacher and, moreover, that the number of publications with at least 10 recorded citations will increase with the number of research articles.

Funding based on academic performance can widen the gap between research and teaching. If the rewards awarded in the field of research are greater than those awarded for education, the university staff will focus more on research than on teaching. While the intention is to reward and encourage, the evaluation inevitably focuses on previous performances rather than current ones, and less so on future ones. Therefore, the quality measurement tools of the research should be treated with greater indulgence, as it is not possible to describe the contributions of an individual in a certain field of research based on simple numerical values.

\section{ACKNOWLEDGEMENT}

This research was supported financially by the project CNFIS-FDI-2018-0582 - Supporting Excellence Research within The Bucharest University of Economic Studies in the context of the principles of sustainable development and open research. 6. Supporting field research excellence in universities Beneficiary: The Bucharest University of Economic Studies.

\section{REFERENCES}

[1] Kothari, C.R., Research Methodology: Methods and Techniques, New Age International Publichers, 2004, Ediţia a 2-a, New Delhi

[2] Beycioğlu, K., Özer, N., Uğurlu, C.T., Teachers'views on educational research, In: Teaching and Teacher Education, 2010, 26, 4, 1088-1093

[3] Everton, T., Galton, M., Pell, T., Teachers' perspectives on educational research: Knowledge and context, In: Journal of Education for Teaching, 2000, 26, 2, 167-182

[4] Drill, K., Miller, S., Behrstock-Sherratt, E., Teachers' perspectives on educational research, American Institutes for Research, Naperville, IL, 2012

[5] Yavuz, M., Analysis of the views of teachers and school administrators about educational research, In: Selçuk Üniversitesi Ahmet Keleşoğlu Eğitim Fakültesi Dergisi, 2009, 27, 143-158

[6] Zeuli, J.S., How do teachers understand research when they read it?, Annual Meeting of the American Education Research Association, San Francisco, 1992

[7] Cohen, L., Manion, L., Morrison, K., Research methods in education, Ediţia 6, New York: Routledge, 2007

[8] Androniceanu, A., Burlacu, S., Integration of educational technologies in universities and students' perception thereof, In: In the International Scientific Conference eLearning and Software for Education, 2017, 2, 26

[9] Sari, M., Researcher teacher: Examination of the views of teachers towards scientific research, In: Kuram ve Uygulamada Eğitim Bilimleri, 2006, 6, 3, 847-879

[10] Burlacu, S., Characteristics of Knowledge-Based Economy and New Technologies in Education, In: Administration and Public Management Review, 2011, 16, 36-41

[11] Şahin, Ç., Arcagök, S., Approaches of elemantary school teachers towards educational research, In: Bilgisayar ve Eğitim Araştırmaları Dergisi, 2013, 1, 2, 1-20

[12] İlhan, N., Şekerci, A.R., Sözbilir, M., Yildirim, A., Development of teacher attitude scale towards educational research: Validity and reliability study, In: Bati Anadolu Eğitim Bilimleri Dergisi, 2013, 4, 8, 31-56

[13] Burlacu, S., Role of Training in the Knowledge Society, In: Proceedings of Administration and Public Management International Conference, 2010, 6, 1, 203-208

[14] Chang, Y.H., Chang, C.Y., Tseng, Y.H., Trends of science education research: An automatic content analysis, In: Journal of Science Education and Technology, 2010, 19, 4, 315-331 
[15] Sözbilir, M., Kutu, H., Yaşar, M.D., Science education research in Turkey: A content analysis of selected features of papers published, Science education research and practice in Europe: Retrospective and prospective, 2012, 341-374, Rotterdam: Sense Publishers

[16] Tsai, C.C., Wen, L.M.C. Research and trends in science education from 1998 to 2002: A content analysis of publication in selected journals, In: International Journal of Science Education, 2005, 27, 1, 3-14

[17] Biesta, G., Bridging the gap between educational research and educational practice: The need for critical distance, In: Educational Research and Evaluation, 2007, 13, 3, 295-301

[18] Yilmaz, D., Kiliçoğlu, G., Investigating graduate and non-graduate teachers' views about educational research, In: Journal of Educational Sciences Research, 2013, 3, 1, 65-85

[19] Elliot, A.J., Murayama, K., On the measurement of achievement goals: Critique, illustration, and application, In: Journal of Educational Psychology, Vol 100(3), Aug 2008, 613-628, https://doi.org/10.1037/0022-0663.100.3.613

[20] Beycioglu, K., Özer, N., The relationship between teacher professional development and burnout, In: Procedia Social and Behavioral Sciences, 2010, 2, 4928-4932, https://doi.org/10.1016/j.sbspro.2010.03.797

[21] McNamara, K., Rational Fictions: Central Bank Independence and the Social Logic of Delegation, In: West European Politics, 2002, 25, 1, 47-76, https://doi.org/10.1080/713601585

[22] Shkedi, A., Can the Curriculum Guide Both Emancipate and Educate Teachers?, In: Curriculum Inquiry, 1998, 28, 2, 209-229

[23] McDonough, W., Constraints on the composition of the continental lithospheric mantle, In: Earth and Planetary Science Letters, 1990, 101, 1-18, https://doi.org/10.1016/0012-821X(90)90119-I

[24] Brown, P.F., Pietra, V.J.D., deSouza, P.V., Lai, J.C., Mercer, R.L., Class-based n-gram models of natural language, In: Computational Linguistics, 1992, 18, 4, 467-479

[25] Bryen, D., Potts, B., Carey, A., So you want to work? What employers say about job skills, recruitment and hiring employees who rely on AAC, In: Augmentative and alternative communication, 2007, 23, 126-39

[26] Massy, W.F., Zemsky, R., Faculty discretionary time: departments and the academic ratchet, In: Journal of Higher Education, 1994, 65, 1, 1-22

[27] Park, S.M., Research, teaching, and service: Why shouldn't women's work count?, In: journal of higher Education, 1996, 67, 46-84

[28] Blackburn, R.T., Lawrence, J.H., Faculty at Work: Motivation, Expectation, Satisfaction, Johns Hopkins University Press, 1995

[29] Vasile, D., Vulturescu, V., Pavelescu, L.C., Dudian, M., Romania's participation to the 7th EU Framewok Programme, In: Industria Textilă, 2015, 66, 4, 226-231

[30] Florescu, M., Lefter, V., Istudor, N., Zaman, G., Vasile, V., Best practices in the field of research evaluation and funding policies, In: Industria Textila, 2009, 60, 1, 34-45

[31] Hills, P.V., Dale, A.J., Research and Technology Evaluation in the United Kingdom, In: Research Evaluation, 1995, 5, 1, 35-44

[32] Irvine, J., Martin, B., Isard, P.A., Investing in the Future: An International Comparison of Government Funding of Academic and Related Research, 1990

[33] Stenhouse, L., What counts as research?, In: British Journal of Educational Studies, 1981, XXIX, 2, 103-114

[34] Rip, A., van der Meulen, B.J.R., The Patchwork of the Dutch Evaluation System, In: Research Evaluation, 1995, 5, $1,45-53$

[35] Campbell, D.F.J., Felderer, B., Evaluating Academic Research in Germany. Patterns and Policies, In: Political Sciences Series, 1997, 48, Viena

[36] Helander, E., Evaluation Activities in the Nordic Countries, In: Scientometrics, 1995, 34, 3, 391-400

[37] Kaukonen, E., Evaluation of Scientific Research in Finland, In: The Evaluation of Scientific Research: Selected Experiences, Paris: OECD, 1997, 12-25

[38] Hangos, K. , The Limits of Peer Review: The Case of Hungary, 71-81

[39] Pfeffer, J., Salancik, G.R., The External Control of Organizations. A ResourceDependence Perspective, Harper \& Row Publishers, New York, 1978

[40] Auranen, O., Nieminen, M., University Research Funding and Publication Performance - An International Comparaison, In: Research Policy, 2010, 822-834

[41] Benner, M., Sandström, U., Institutionalizing the triple helix: research fundingand norms in the academic system, In: Research Policy, 2000, 29, 2, 291-301

[42] Jongbloed, B., Steering the Dutch academic research enterprise: Universities' responses to project funding and performance monitoring, The 20th CHER Conference, Dublin, 2007

[43] Calvert, J., Is there a role for 'basic research' in Mode 2?, In: VEST. Journal for Science and Technology Studies, 2000, 35-51

[44] Krücken, G., Learning the 'new, new thing': on the role of path dependency inuniversity structures, In: Higher Education, 2003, 46, 3, 315-339

[45] Hakala, J., Ylijoki, O.-H., Research for whom? Research orientations in threeacademic cultures, In: Organization, 2001, 8, 2, 373-380 
MARGARETA STELA FLORESCU ${ }^{1}$, ADRIANA ANA MARIA DAVIDESCU² ${ }^{2}$ MIHAELA MOSORA ${ }^{3}$, CRISTINA ALPOPI ${ }^{1}$, MARIAN NASTASE $^{4}$

${ }^{1}$ Bucharest University of Economic Studies, Faculty of Administration and Public Management, 6 Piata Romana, 010374, Bucharest, Romania e-mail: margareta.florescu@ari.ase.ro, cristina.alpopi@ase.ro

${ }^{2}$ National Scientific Research Institute for Labour and Social Protection, 6-8, Povernei Street, 010643 Bucharest, Romania e-maill: adrianaalexandru@yahoo.com

${ }^{3}$ Bucharest University of Economic Studies, Faculty of Theoretical and Applied Economics, e-mail: mihaela.mosora@gmail.com

${ }^{4}$ Bucharest University of Economic Studies, Faculty of Management, Piata Romana, No. 6, 010374, Bucharest, Romania e-mail: nastasem1@yahoo.com

Corresponding author: MARGARETA-STELA FLORESCU

e-mail: margareta.florescu@ari.ase.ro 